\title{
ACESSO À JUSTIÇA E TÉCNICAS DE JULGAMENTO DE CASOS REPETITIVOS
}

\author{
Tese de Doutorado \\ Orientador: Prof. Associado Dr. Carlos Alberto de Salles
}

UNIVERSIDADE DE SÃO PAULO

FACULDADE DE DIREITO

São Paulo

2018 



\title{
ACESSO À JUSTIÇA E TÉCNICAS DE JULGAMENTO DE CASOS REPETITIVOS
}

Tese apresentada à Banca Examinadora do Programa de Pós-Graduação em Direito, da Faculdade de Direito da Universidade de São Paulo, como exigência parcial para obtenção do título de Doutora em Direito, na área de concentração de Direito Processual Civil, sob orientação do Prof. Associado Dr. Carlos Alberto de Salles

\author{
UNIVERSIDADE DE SÃO PAULO \\ FACULDADE DE DIREITO \\ São Paulo \\ 2018
}


Autorizo a reprodução e divulgação tota ou parcial deste trabalho, por qualquer meio convencional ou eletrônico, para fins de estudo e pesquisa, desde que citada a fonte.

\author{
Catalogação da Publicação \\ Serviço de Biblioteca e Documentação \\ Faculdade de Direito da Universidade de São Paulo
}

Asperti, Maria Cecilia de

Acesso à justiça e técnicas de julgamento de casos repetitivos / Maria Cecilia de Asperti ; orientador Carlos Alberto de Salles -- São Paulo, 2018.

414

Tese (Doutorado - Programa de Pós-Graduação em Direito Processual) - Faculdade de Direito, Universidade de São Paulo, 2018.

1. Acesso à justiça. 2. Litigiosidade Repetitiva. 3. Incidente de Resolução de Demandas Repetitivas. 4. Recurso Especial e Extraordinário Repetitivos. 5. Contraditório. I. Salles, Carlos Alberto de, orient. II. Título. 
ASPERTI, Maria Cecilia de Araujo. Acesso à justiça e técnicas de julgamento de casos repetitivos. $414 \mathrm{f}$. Tese (Doutorado) - Faculdade de Direito, Universidade de São Paulo, São Paulo, 2018.

Aprovada em:

Banca Examinadora

Professor(a) Dr(a).

Instituição:

Julgamento:

Professor(a) Dr(a).

Instituição:

Julgamento:

Professor(a) Dr(a).

Instituição:

Julgamento:

Professor(a) Dr(a).

Instituição:

Julgamento:

Professor(a) Dr(a).

Instituição:

Julgamento: 



\section{AGRADECIMENTOS}

Escrever uma tese de doutorado é, certamente, uma tarefa trabalhosa, que demanda uma série de renúncias e de investimento emocional e intelectual. Mas não deixa de ser um enorme privilégio, ainda mais quando se tem a chance de fazê-lo em uma universidade pública. Por isso, mais do que exaltar o esforço empreendido, o agradecimento vai no sentido de reconhecer as oportunidades que se colocaram ao longo desse incrível percurso que foi a pós-graduação, e principalmente as trocas e apoios generosos que recebi ao longo desses anos.

Agradeço à Universidade de São Paulo, um lugar em que me sinto em casa desde a infância. Não sem as críticas necessárias - pois somente assim poderemos avançar - espero, sinceramente, que a USP seja uma sempre casa acolhedora e que a oportunidade que tive seja efetivamente democratizada a todos e todas, independentemente de suas origens, classes, raça ou gênero.

Agradeço também a minha atual casa, a Escola de Direito da Fundação Getulio Vargas, que me acolheu desde 2007 como pesquisadora, gestora e hoje como professora. O aprendizado que tive na FGV é incomensurável e contínuo, com colegas, funcionários/as e com alunos/as, me fazendo ter a certeza de que o caminho que passei a percorrer a partir do mestrado é o que me faz verdadeiramente feliz e realizada.

Sendo impossível agradecer a todos e todas que atravessaram meu caminho ao longo desse processo, faço esse agradecimento em nome de alguns/algumas que estiveram particularmente envolvidos nessa trajetória e que ajudaram fazer desta algo tão especial e que tanto mudou a minha vida.

Primeiro, agradeço ao Professor Carlos Alberto de Salles, por quem eu tenho o privilégio de ser orientada desde o mestrado. Talvez o Prof. Salles sequer saiba o quão é querido e admirado por seus/suas orientandos/as, e que é, para nós, um verdadeiro exemplo de professor e de profissional. Sou grata não só pela orientação neste trabalho, mas por todo convívio desde 2011, quando ingressei no programa de pós-graduação. Com o Prof. Salles, aprendemos que é possível ser um docente que dialoga com seus/suas alunos/as como colegas, e que é nesse diálogo que conseguimos efetivamente crescer e nos mantermos constantemente inspirados.

Com os/as orientandos/as do Prof. Salles - auto e carinhosamente denominados de "Sallesianos" - formamos um grupo de pesquisa, discussão e, principalmente, de apoio mútuo, fazendo da experiência às vezes solitária da academia uma vivência coletiva muito 
mais interessante. Agradeço aos/às amigos/as Alex Alckimin, Amanda Guimarães, Bruna Braga, Bruno Megna, Bruno Takahashi, e o convidado especial Michel Roberto de Souza, por essa troca maravilhosa, que espero que continuemos fazendo por muitos e muitos anos.

Não poderia também deixar de agradecer a todos os membros e membras do Departamento Jurídico XI de Agosto, com quem vivo aventuras e sufocos semanais, na tentativa (às vezes bem sucedida, noutras frustrada) de atender a invencível demanda por acesso à justiça e por acesso a direitos. Agradeço a todos/as os/as colegas - funcionários/as, advogados/as e alunos/as - que topam, por motivos as vezes incompreensíveis a nós mesmos/as, continuar nessa infindável empreitada.

Um agradecimento mais do que especial é direcionado aos meus alunos e alunas da FGV, tanto da pós-graduação quanto da graduação, com quem tenho o privilégio cotidiano de dialogar não só sobre processo civil, mas sobre todos os acontecimentos ao nosso redor, de forma crítica e sincera. Com eles/as, tenho questionado muitos sensos e certezas, e por eles/as tenho sido constantemente instigada a repensar minha visão sobre o Judiciário, a academia e o nosso papel nessa sociedade tão desigual.

Durante essa trajetória, há algumas mulheres incríveis que servem de exemplo para mim em muitos sentidos. Assim, um agradecimento muito especial é direcionado às amigas Bruna Braga, Catarina Barbieri, Cecilia Barreto, Clio Radomysler, Cristina Cajuella, Daniela Gabbay, Karina Denari, Manuela Leitão, Monica Sapucaia, Paula Zambelli, Rachel Ripardo, Susana Henriques da Costa, Yonara Dantas, e a todas as inúmeras conversas que tivemos sobre os dilemas da pesquisa e da docência, inclusive sobre o de ser mulher nesses espaços. Como disse Catarina Barbieri, o momento é de estarmos juntas e resistir. E eu não poderia estar em melhor companhia.

Agradeço também a generosa troca que tive a oportunidade de realizar no exame de qualificação com os professores Paulo Eduardo Alves da Silva e Heitor Vitor Mendonça Sica, cujas observações e questionamentos foram fundamentais na elaboração desse trabalho e no aprofundamento do estudo desse tema. Também com Daniela Gabbay e Susana Henriques da Costas, tive a chance de compartilhar infindáveis inquietações e de construir, conjuntamente, algumas das reflexões que foram fundamentais para o desenvolvimento deste trabalho.

Aos meus/minhas queridos/as amigos/as, que sempre estiveram ao meu lado nas muitas etapas dessa jornada. Agradeço a Letícia Martins, Marcela Bocchi, Mariana Anjos, Mariana Bastos, Mariana Ferraz, Natália Felipe, Natali Santos, Pollyana Soares, Vivian 
Calderoni, Pedro Carvalho e Silva, Tainá Munhoz e Ana Luiza Westphalen pela incansável torcida.

Finalmente, reservo à minha família um especial agradecimento, não só pelo apoio durante a tese, mas durante toda a minha formação. Ao meu pai, que me instigou o amor pelos estudos, me fazendo prometer um dia ler para ele todos os livros que ele leu para mim antes de dormir. À minha mãe e minha melhor amiga, com quem dividi angústias diárias, desde a primeira aula que tive no mestrado até a primeira que tive que dar como professora (e tantas que se seguiram...). À minha irmã, meu cunhado e meu afilhado, sempre ao meu lado, trazendo uma inestimável leveza e alegria para minha vida. À família Morelli, que me acolheu de coração, e que me faz me sentir tão parte deles como se tivesse nascido em Jaú. Ao Murilo, meu melhor companheiro, parceiro e amigo, que pacientemente ouviu e discutiu comigo essa tese e que compartilhou comigo todos os momentos importantes que vivenciei desde que estamos juntos. 



\section{RESUMO}

ASPERTI, Maria Cecilia de Araujo. Acesso à justiça e técnicas de julgamento de casos repetitivos. $414 \mathrm{f}$. Tese (Doutorado) - Faculdade de Direito, Universidade de São Paulo, São Paulo, 2018.

As técnicas processuais de julgamento de casos repetitivos expressam uma tendência de reformas informadas pela promoção de maior segurança jurídica e eficiência na prestação jurisdicional. O Código de Processo Civil de 2015 destaca o Incidente de Resolução de Demandas Repetitivas e o recurso especial e extraordinário repetitivos como técnicas de formação de teses jurídicas acerca de questões jurídicas repetitivas, a serem aplicadas em casos pendentes e futuros. Assim, a tese busca problematizar a relação entre essas técnicas processuais e a noção de acesso à justiça, levantando-se, ainda, perguntas específicas sobre (i) como os litigantes repetitivos e ocasionais utilizam e são afetados pela aplicação dessas técnicas e sobre (ii) como se dá a participação e a representação dos interesses dos destinatários da tese jurídica. As hipóteses traçadas foram as de que (i) tais técnicas tendem a favorecer uma utilização mais estratégica por parte dos litigantes repetitivos e que (ii) os interesses dos "ausentes" e dos "sobrestados" são representados de forma deficiente (déficit de representatividade) no julgamento de casos repetitivos, mesmo com a participação de amicus curiae ou a realização de audiência pública. Com relação ao conceito de "acesso à justiça", deve este ser compreendido como um direito social a uma efetiva participação no sistema de justiça que viabilize o seu uso na promoção das transformações sociais necessárias para superação das desigualdades persistentes em nossa sociedade. Além disso, o acesso à justiça é, também, uma perspectiva metodológica, pela qual são priorizados métodos empíricos e análises comparativas para investigação das experiências de diferentes grupos e indivíduos no sistema de justiça e os impactos sociais da atuação de seus agentes e instituições. Para verificação das hipóteses propostas, foi realizado, além da pesquisa teórica, um estudo empírico-jurisprudencial sobre as teses jurídicas firmadas em sede de julgamento de recurso especial repetitivo e um estudo de caso sobre a discussão, pelo STJ, da conformidade do sistema de scoring de crédito com os preceitos do Código de Defesa do Consumidor. Verificou-se, então, que a sistemática de julgamento da tese jurídica tende a favorecer os litigantes repetitivos, que conseguem influir de forma mais efetiva no procedimento e na formulação de teses favoráveis aos seus interesses. Essa disparidade tornase ainda mais sensível diante do papel decisivo exercido pelas partes dos casos paradigma, que acabam defendendo os interesses dos "sobrestados" e dos "ausentes" no julgamento da tese jurídica. Nesse sentido, participação direta destes não pode ser de antemão obstada ou substituída pela atuação dos amici curiae, o Ministério Público ou a Defensoria Pública, que não serão necessariamente capazes de fazer frente às vantagens estratégicas dos litigantes repetitivos, tampouco terão interesses alinhados com os litigantes ocasionais. Conclui-se ser fundamental resgatar a perspectiva do acesso à justiça para compreender a litigiosidade repetitiva enquanto realidade social e refletir sobre as diversas questões atinentes à interpretação e aplicação das técnicas de julgamento de casos repetitivos, de modo a se assegurar uma ampla e efetiva participação dos litigantes ocasionais, "sobrestados" e "ausentes" no julgamento da tese jurídica.

Palavras-chave: Acesso à justiça. Litigiosidade Repetitiva. Incidente de Resolução de Demandas Repetitivas. Recurso Especial e Extraordinário Repetitivos. Reforma do Judiciário. Código de Processo Civil de 2015. Contraditório. Participação. Litigante Habitual. Litigante Eventual. Representatividade Adequada. 


\begin{abstract}
ASPERTI, Maria Cecilia de Araujo. Access to justice and mechanisms for judging repeated cases. $414 \mathrm{f}$. PhD Thesis - Law School, University of São Paulo, São Paulo, 2018.

Procedural mechanisms specifically aimed at judging repeated cases express a tendency of reforms concerned with legal certainty and efficiency in court administration. In that sense, the Code of Civil Procedure of 2015 provides for the "Incident of Resolution of Repetitive Demands" ("IRDR") and the "repeated special and extraordinary appeals", as mechanisms to consolidate legal theses on repeated legal issues, and to apply such thesis in pending and future cases. Thus, this research discusses the relationship between these procedural mechanisms and the notion of access to justice, raising specific questions about (i) how do repeat players and one-shooters resort to and are affected such mechanisms and (ii) how do other players who will be affected by the legal thesis can participate or have its interests represented in these procedural venues. The hypotheses were that (i) such mechanisms tend to favor a more strategic use by repeat players, and (ii) the interests of parties of pending and futures cases are poorly represented (lack of adequate representation) in the judgment of repeated cases, even with the participation of amicus curiae and the designation of public hearings. As to the definition of "access to justice", it can be understood as a social right to participate effectively in the justice system, enabling its use in promoting the social transformations that are needed to overcome persistent inequalities in our society. In addition, access to justice is also a methodological perspective, whereby empirical methods and comparative analysis are prioritized to investigate the experiences of different groups and individuals in the justice system and the social impacts of the actions of their agents and institutions. To verify the hypothesis, besides a theoretical study, an empirical research was carried out to analyze the legal thesis that were consolidated through repeated special appeals, as well as a case study on the discussion by the Superior Court of Justice on the conformity of the credit scoring system with the provisions of consumer law. It was verified, then, that the procedure to trial legal thesis in repeated cases tend to favor repeat players, who are able to exert influence, in a more effective way, in order to obtain the consolidation of legal thesis that favor their interests. This disparity between repeat players and one-shooters becomes even more meaningful in view of the decisive role played by the parties to the leading cases, which end up representing the interests of the parties of pending and futures cases. In this sense, the direct participation of such "absentees" cannot be obstructed or replaced by that of the amici curiae, the Public Prosecutor's Office or the Public Defender's Office, which will not necessarily be able to match the strategic advantages of the repeat players, nor will they have interests in line with those of the one-shooters. Therefore, it is fundamental to redeem the access to justice perspective to understand repeated litigation as a social reality, and to reflect on the various issues related to the interpretation and application of the procedural mechanisms, and thus to ensure a broad and effective participation of litigants and "absentees" in the judgment of the legal thesis.
\end{abstract}

Keywords: Access to Justice. Repeated Litigation. Incident of Resolution of Repetitive Demands. Repeated Special and Extraordinary appeals. Brazilian Judicial Reform. Brazilian Code of Civil Procedure of 2015. Due process of law. Participation. Repeat Player. OneShooter. Adequate representation. 


\section{RIASSUNTO}

ASPERTI, M. C. A. Accesso alla giustizia e le tecniche di giudizio di casi ripetitivi. $414 \mathrm{f}$. Tesi (Dottorato). Facoltà di Giurisprudenza, Università di San Paolo del Brasile, São Paulo del Brasile, 2018.

Le tecniche processuali di giudizio di casi ripetitivi esprimono una tendenza di riforme basate sulla promozione di una maggior certezza giuridica ed efficienza nella prestazione giurisdizionale. Il Codice di Procedura Civile di 2015 pone in evidenza l'incidente di Risoluzione di Processi Ripetitivi e il ricorso speciale e straordinario ripetitivi come essendo tecniche di formazione di tesi giuridiche a rispetto di questioni giuridiche ripetitive che saranno adoperate in casi pendenti e futuri. In questo modo, la tesi si propone problematizzare la relazione tra le riferite tecniche processuali e la nozione di accesso alla giustizia, arguendosi per la sua impossibilità di esecuzione e per l'indebolimento dell'idea di accesso alla giustizia. Inoltre, due domande specifiche sono fatte in questa tesi: come le parti litiganti ripetitivi ed occasionali utilizzano e sono affettati dalla applicazione di riferite tecniche e come è la partecipazione e la rappresentanza degli interessi dei destinatari di tali tesi giuridiche (deficit di rappresentanza) nel giudizio di casi ripetitivi, pure con meccanismi di ampiamento partecipativo, come l'amicus curiae e le udienze pubbliche. In relazione al concetto di "accesso alla giustizia", deve essere capito come un diritto sociale a una effettiva partecipazione nel sistema di giustizia, di forma che la sua utilizzazione promuova le trasformazioni sociali necessarie al superamento delle disuguaglianze persistenti nella nostra società. In una prospettiva metodologica, per la quale sono preferiti i metodi empirici e le analisi comparative per l'investigazione delle esperienze di differenti gruppi e individui nel sistema di giustizia e gli impatti sociali di attuazione dei suoi agenti ed istituzioni. Per verificare le ipotesi, è stato elaborato, oltre alla ricerca teorica, uno studio empirico e giurisprudenziale sulle tesi giuridiche formate nei giudizi di ricorsi speciali ripetitivi e uno studio di caso sulla discussione, nell'ambito del STJ, della conformità legale del sistema di scoring di credito com i precetti del Codice di Difesa dei Consumatori. Si è verificato che la sistematica di tale giudizio tende a favorire i litiganti ripetitivi, che riescono a influire di forma più effettiva nella procedura e nella formulazione di tesi favorevoli ai suoi interessi. Tale disparità è ancor più notabile se considerato il ruolo decisivo dei litiganti occasionali nei casi paradigmatici, che difendono interessi di parti estranee al giudizio della tesi giurisprudenziale. La partecipazione diretta delle parti interessate non può essere proibita o sostituita dalla attuazione di altre entità, come l'amicus curiae, il Pubblico Ministero o dal Difensore Civico, perché tali entità non saranno sempre capaci di confrontare i vantaggi strategici dei litiganti ripetitivi o nemmeno saranno sempre in linea con gli interessi dei litiganti occasionali. La tesi conclude che è fondamentale il riscatto della prospettiva di accesso alla giustizia per comprendere la litigiosità ripetitiva come realtà sociale e riflettere sulle diverse questioni attinenti all'interpretazione ed applicazione delle tecniche di giudizio in casi ripetitivi, di modo ad assicurare una ampia ed effettiva partecipazione dei litiganti occasionali e delle parti estranee al giudizio di determinata tesi giuridica.

Parole chiave: Accesso alla giustizia. Litigiosità Ripetitiva. Incidente di Risoluzione di Processi Ripetitivi. Ricorso Speciale e Straordinario Ripetitivo. Riforma della Giustizia. Codice di Procedura Civile di 2015. Contraddittorio. Partecipazione. Litigante abituale. Litigante occasionale. Rappresentanza adeguata. 


\section{ÍNDICE DE TABELAS}

Tabela 1 - Vantagens usufruídas por litigantes habituais de acordo com Marc Galanter e a partir das particularidades do contexto brasileiro

Tabela 2 - Temas e recursos especiais repetitivos em que foram realizadas audiências públicas no STJ até março/2017.

Tabela 3 - Quadro comparativo com relação ao envolvimento de litigantes habituais e ocasionais nos RRCs.

Tabela 4 - Eixos de análise e questões do estudo de caso.

Tabela 5 - Entidades e pessoas participantes da audiência pública, em que qualidade e manifestando qual posicionamento .270 


\section{ÍNDICE DE GRÁFICOS}

Gráfico 1 - Número de processos sobrestados em razão da aplicação do artigo 1.037, II, do CPC/2015 que foram contabilizados pelo STJ em julho de 2017, a partir de dados disponibilizados pelos tribunais entre julho de 2016 e junho de 2017

Gráfico 2 - Percentual de teses jurídicas firmadas a partir de recursos representativos da controvérsia por tribunal de origem (considerando o primeiro RRC afetado)

Gráfico 3 - Classificação da parte recorrente nos RRCs analisados.

Gráfico 4 - Classificação da parte recorrida nos RRCs analisados

Gráfico 5 - Classificação das questões submetidas a julgamento e teses jurídicas por área do Direito. 238

Gráfico 6 - Percentual de teses jurídicas julgadas por cada órgão do STJ 240

Gráfico 7 - Percentual de teses firmadas em favor de litigantes repetitivos ou ocasionais ...243

Gráfico 8 - Percentual de teses jurídicas firmadas em favor de litigantes repetitivos ou ocasionais por área do Direito 


\section{LISTA DE ABREVIATURAS E SIGLAS}

ADI - Ação Direta de Inconstitucionalidade

AMB - Associação de Magistrados Brasileiros

Anatel - Agência Nacional de Telecomunicações

CF - Constituição Federal

$\mathrm{CNJ}$ - Conselho Nacional de Justiça

CDC - Código de Defesa do Consumidor

CTBC - Companhia de Telecomunicações do Brasil Central

E.g. - exempli gratia

ENAJUD - Estratégia Nacional de Não Judicialização

FMI - Fundo Monetário Internacional

IPEA - Instituto de Pesquisa Econômica Aplicada

IRDR - Incidente de Resolução de Demandas Repetitivas

I.e. $-i d$ est

GLO - Group Litigation Order

LOAS - Lei Orgânica da Assistência Social

RE - Recurso Extraordinário

REsp - Recurso Especial

RRC - Recurso Representativo da Controvérsia

SEC - Securities and Exchange Comission

STF - Supremo Tribunal Federal

STJ - Superior Tribunal de Justiça

STFC - Serviço Telefônico Fixo Comutado

TJSP - Tribunal de Justiça do Estado de São Paulo

TJRS - Tribunal de Justiça do Estado do Rio Grande do Sul

v.g. - verbi gratia 


\section{SUMÁRIO}

INTRODUÇÃO

PARTE I: ACESSO À JUSTIÇA E O PROCESSO NA ATUALIDADE

1. “ACESSO À JUSTIÇA” E LITIGIOSIDADE REPETITIVA NAS REFORMAS PROCESSUAIS

1.1. Discursos, agendas e significados

1.2. Discussões acadêmicas e apropriação legislativa do tema "acesso à justiça" 30

1.3. Litigiosidade e litigiosidade repetitiva 37

1.4. Prevalência da eficiência e da segurança jurídica sobre o acesso à justiça ... 41

1.5. Litigiosidade repetitiva como problema e acesso à justiça como causa 47

2. AINDA FAZ SENTIDO FALAR EM ACESSO À JUSTIÇA?

2.1. Uma agenda ultrapassada?. 51

2.2. Acesso à justiça enquanto perspectiva metodológica 52

2.3. Acesso à justiça como direito social. 57

2.3.1. Fronteiras dinâmicas da injustiça e distribuição do acesso 57

2.3.2. Desigualdade no acesso e na justiça que se acessa. 58

2.4. Litigantes repetitivos, ocasionais e os ausentes 63

Síntese conclusiva da Parte I 79

\section{PARTE II: PARTICIPAÇÃO E REPRESENTATIVIDADE NO PROCESSO CIVIL .83}

3. PARTICIPAÇÃO E REPRESENTATIVIDADE NO PROCESSO CIVIL 85

3.1. Participação no processo e acesso à justiça .85

3.1.1. Participação e distributividade no processo civil .............................................. 85

3.1.2. Devido processo legal e o direito de participar no processo .................................. 88

3.1.3. Excepcionalidade da mitigação da participação no processo ................................. 95

3.2. Participação e representatividade no processo civil 105

3.2.1. Representação e substituição processual 105

3.2.2. Representatividade adequada no processo coletivo 107

Síntese conclusiva da Parte II 115

PARTE III: ACESSO À JUSTIÇA E TÉCNICAS DE JULGAMENTO DE CASOS REPETITIVOS.

\section{PARTICIPAÇÃO E REPRESENTATIVIDADE NAS TÉCNICAS DE} JULGAMENTO DE CASOS REPETITIVOS

4.1. Técnicas de julgamento de casos repetitivos. 121

4.1.1. Diferentes racionalidades processuais relacionadas a "casos repetitivos"

4.1.2. Julgamento por amostragem $\mathrm{x}$ Técnica processual objetiva 
4.1.3. "Casos repetitivos" ou "questões repetitivas"?

4.2. Decisão proferida no julgamento de casos repetitivos e seus efeitos 139

4.2.1. A tese jurídica é um precedente?

4.2.2. Aproximações com a issue preclusion da common law..................................... 149

4.2.3. Participação e efeitos da tese jurídica .................................................................. 156

4.3. Dilemas da participação nas técnicas de julgamento de casos repetitivos.. 157

4.3.1. Disparidade entre litigantes repetitivos e ocasionais

4.3.2. Representatividade dos "litigantes-sombra"

4.4. Participação na instauração do procedimento 170

4.4.1. Escolha do caso paradigma nos recursos repetitivos 171

4.4.1.1. Critérios para afetação do recurso representativo da controvérsia171

4.4.1.2. Desistência do recorrente como estratégia do litigante habitual .. 177

4.4.2. Instauração e admissibilidade do IRDR. 180

4.4.2.1. Caso originário e iniciativa de instauração do IRDR 180

4.4.2.2. Desistência da parte/recorrente e a atuação do Ministério Público187

4.5. Sobrestamento de processos 188

4.6. Há uma efetiva possibilidade de "distinguishing"? 194

4.7. Participação no julgamento do recurso repetitivo e do IRDR 195

4.7.1 Partes do caso paradigma: representatividade adequada?

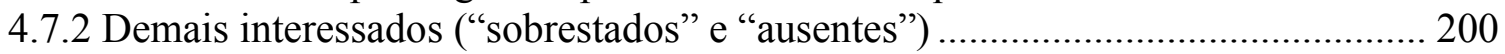

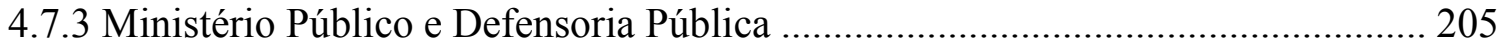

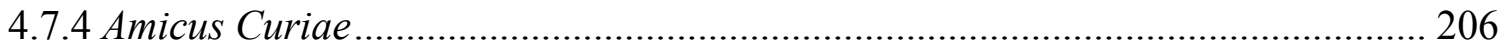

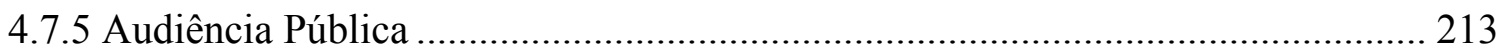

4.8. Recorribilidade das decisões proferidas no incidente ou no recurso repetitivo 222

4.9. Revisão da tese jurídica ("overruling") 224

5. LITIGANTES REPETITIVOS E OCASIONAIS NO STJ

5.1. Estudo empírico-jurisprudencial: objetivo e metodologia 229

5.2. Recursos representativos da controvérsia por tribunais de origem

5.3. Partes (recorrente e recorrido)

5.4. Questão submetida a julgamento e teses firmadas por área do Direito ......2237

5.5. Tempo de tramitação entre a afetação e o trânsito em julgado

5.6. Formação da tese jurídica e favorecimento de litigantes habituais ou ocasionais 241

5.7. Considerações sobre a análise empírico-jurisprudencial ..... .244

6. PARTICIPAÇÃO E REPRESENTATIVIDADE NO RECURSO ESPECIAL REPETITIVO: UM ESTUDO DE CASO

6.1. Estudo de caso: objetivos e metodologia

6.2. O caso do sistema de scoring de crédito 249

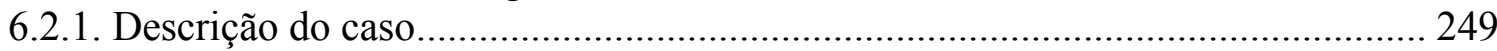

6.2.2. Partes, seus representantes e principais alegações deduzidas .............................. 250

6.2.3. Provas e decisões proferidas nos casos paradigma .......................................... 257

6.2.4. Escolha do Recurso representativo da controvérsia e sobrestamento.................... 264

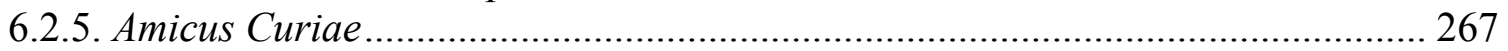

6.2.6. Ministério Público e Defensoria Pública ........................................................... 267

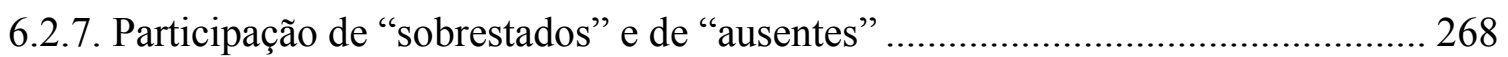

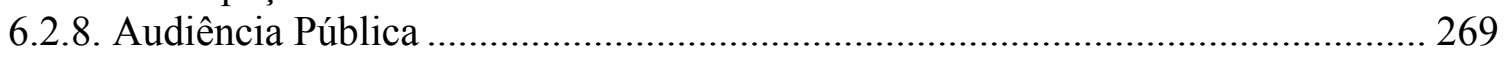

6.2.9. Julgamento, fundamentação e tese jurídica....................................................... 277

6.3. Considerações sobre o estudo de caso 
CONCLUSÃO

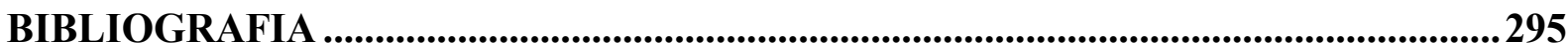

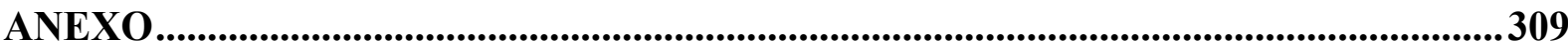

Relação dos temas julgados pelo STJ analisados no estudo empírico-jurisprudencial309 



\section{INTRODUÇÃO}

Um dos dados mais conhecidos e frequentemente veiculados sobre o Judiciário brasileiro é o volume de processos em trâmite e de ações novas ajuizadas a cada ano ${ }^{1}$. De acordo com a série histórica do relatório Justiça em Número, do Conselho Nacional de Justiça, o número de processos e recursos (entre casos novos e pendentes) ultrapassou, em 2013, a marca dos 100 milhões, chegando em 2016 a um total próximo a 110 milhões ${ }^{2}$. Uma das consequências desse volume de processos seria, ao menos em tese, o congestionamento das instituições judiciárias, e, por sua vez, a morosidade e inefetividade da tutela jurisdicional.

Ao lado de reformas institucionais ${ }^{3}$ e de medidas essencialmente gerenciais ${ }^{4}$, esse crescimento da litigiosidade e o (crônico) congestionamento das instituições judiciárias ainda que sem um diagnóstico claro de suas causas - foram fatores que motivaram a criação de instrumentos processuais voltados à otimização do julgamento de questões consideradas similares, por meio da uniformização de entendimentos jurisprudenciais. É nesse contexto, e informadas por esse intuito, que foram concebidas as técnicas processuais de julgamento de casos repetitivos $^{5}$, notadamente aquelas referidas pelo artigo 928 do Código de Processo Civil de 2015, quais sejam, o Incidente de Resolução de Demandas Repetitivas (IRDR) e os recursos especial e extraordinário repetitivos. Tais técnicas seriam voltadas a conferir um entendimento uniforme às questões de direito recorrentemente suscitadas em demandas e recursos decorrentes do crescimento da litigiosidade repetitiva, tida como uma "problemática"

\footnotetext{
${ }^{1}$ CANÁRIO, Pedro. "Quase 110 milhões de processos passaram pelo Judiciário em 2016, segundo CNJ". Conjur. 4 set. 2017. Acesso em https://www.conjur.com.br/2017-set-04/110-milhoes-processos-passaramjudiciario-2016, acesso em 20 dez. 2017; "Explosão de litigiosidade exige mudanças no Judiciário, afirma Ricardo Lewandowski”. Notícias STF. $20 \quad$ nov. $2014 . \quad$ Disponível em $<$ http://www.stf.jus.br/portal/cms/verNoticiaDetalhe.asp?idConteudo=280214>, acesso em 20 dez. 2017;

${ }^{2}$ Em 2013, o volume de processos e recursos (“casos") que tramitaram no Judiciário brasileiro (casos pendentes somados casos novos) foi de 100,1 milhões. Esse número vem aumentando anualmente, tendo atingido, em 2016, o total de 109,1 milhões, sendo destes 30,8 milhões de casos novos. Conforme CONSELHO NACIONAL DE JUSTIÇA. Justiça em Números 2017 (ano-base de 2016). Disponível em <http://www.cnj.jus.br/programase-acoes/pj-justica-em-numeros>, acesso em 8 set. 2017, p. 66-68.

${ }^{3}$ Como a criação do Conselho Nacional de Justiça, pela Emenda Constitucional no 45/2004. Vide Capítulo 1, item 1.4 .

${ }^{4}$ Como as metas de produtividade do Conselho Nacional de Justiça, que vêm sendo traçadas desde 2009. Conforme site do CNJ, "as metas nacionais do Poder Judiciário representam o compromisso dos tribunais brasileiros com o aperfeiçoamento da prestação jurisdicional, buscando proporcionar à sociedade serviço mais célere, com maior eficiência e qualidade" (disponível em <http://www.cnj.jus.br/gestao-eplanejamento/metas/sobre-as-metas>, acesso em 4 jan. 2017).

${ }^{5}$ Usa-se a expressão "casos" de modo coerente com a definição do artigo 928 do Código de Processo Civil, ou seja, para se referir conjuntamente a processos e recursos.
} 
central às reformas processuais que instituíram as técnicas de julgamento de casos repetitivos 6 .

Entender os contornos e características dessa litigiosidade repetitiva é fulcral, portanto, ao estudo de instrumentos processuais que se prestem a lidar com essa realidade. Tem-se, nesse sentido, que a litigiosidade repetitiva pode ser associada a proliferação de demandas envolvendo entes públicos ${ }^{7}$ e pessoas jurídicas de direito privado que, justamente em razão de seu porte e de terem sua atuação regulada pelas mesmas leis e atos normativos, e por se utilizarem de instrumentos contratuais padronizados, tendem a judicializar ou de serem acionados judicialmente em decorrência questões de fato e de direito também análogas, em volume compatível com a magnitude de suas atividades.

Por serem motivadas pela busca por eficiência, segurança jurídica e celeridade da prestação jurisdicional, tais técnicas de julgamento de casos repetitivos não costumam a ser analisadas da perspectiva daqueles para quem um processo judicial considerado repetitivo pode ser o primeiro e único contato de um indivíduo com o Judiciário ou com o sistema de justiça. Há, para esse indivíduo, a realização de seu direito de acessar à justiça? O que isso significaria, e o que a realização desse direito implicaria?

O estudo aqui proposto parte, justamente, de uma inquietação sobre como o Judiciário e o processo civil lidam com essa litigiosidade repetitiva e como se dá o acesso à justiça daqueles que podem ser atingidos pelo julgamento de questões jurídicas consideradas repetitivas. É nesses termos que se definiu, como principal problema de pesquisa a relação entre essas técnicas processuais e a noção de acesso à justiça.

Como se verá mais detidamente nos primeiros capítulos da tese, a noção de acesso à justiça é aqui entendida tanto um direito social, quanto como uma perspectiva metodológica, pela qual propõe a priorização de métodos empíricos e de análises comparativas que investiguem as experiências de diferentes grupos e indivíduos no sistema de justiça os impactos sociais da atuação de seus agentes e instituições, com o propósito de problematizar o papel do direito na sociedade e a sua capacidade de superar (e não reproduzir) desigualdades. Como direito social, o acesso à justiça tem de ser compreendido não só como o direito de acessar, mas de efetivamente participar no sistema de justiça, para que seja possível, idealmente, utilizar esse sistema para promover as transformações sociais necessárias para

\footnotetext{
${ }^{6}$ Vide Capítulo 1, item 1.4.

${ }^{7}$ Aqui entendidos como as pessoas jurídicas de direito público interno, conforme artigo 41 do Código Civil, ou seja, entes da administração pública direta e indireta.
} 
superação das desigualdades sociais, de raça, gênero, orientação sexual, etc., persistentes em nossa sociedade

Partindo-se da perspectiva metodológica do acesso à justiça, não seria suficiente analisar a técnica processual em si, sem investigar como os diferentes atores a utilizam ou são atingidos pela sua aplicação. Isso é especialmente pertinente no âmbito da litigiosidade repetitiva, em que se tem, de um lado, um litigante que se envolve com frequencia em casos similares (o Estado, instituições financeiras, concessionárias prestadoras de serviços público, empresas varejistas, etc.) e, de outro, litigantes para quem a demanda é única, e que recorrem ao Judiciário apenas circunstancialmente (segurados, consumidores, contribuintes).

Marc Galanter, em seu famoso texto o potencial distribuitivo do processo civil e das instituições de justiça ${ }^{8}$, propôs a conhecida tipologia de litigantes repetitivos (ou habituais), e litigantes ocasionais (ou eventuais), para conjecturar que aqueles possuíriam significativas vantagens estratégicas em comparação a estes, tendo em vista, justamente, a recorrência com que atuam no Judiciário com questões similares e os incentivos para possuem para angariar expertise, especialização e para “jogar” pela mudança das regras e das instituições a longo prazo.

Trazendo essa reflexão para o âmbito do processo civil, faz-se pertinente analisara como as diferentes técnicas processuais e as formas de participação por elas propiciadas reproduzem, criam ou reduzem/desestabilizam desigualdades. Para isso, é necessário compreender como os diferentes atores utilizam essas técnicas e como as diversas formas de participação no processo podem fortalecer ou enfraquecer as capacidades dos litigantes.

Sobre essa relação entre o acesso à justiça e as técnicas de julgamento de casos repetitivos, foi formulada a pergunta sobre como os litigantes repetitivos e litigantes ocasionais utilizam e como são afetados pela utilização dessas técnicas. Em sendo a sistemática proposta por tais técnicas processuais justamente a de se viabilizar a formação de uma tese jurídica a ser aplicada não somente no caso originário (ou caso paradigma), mas em todos os casos pendentes e futuros em que a mesma questão jurídica for suscitada, suscita-se também o questionamento sobre como se dá a participação e a representação dos interesses daqueles que serão atingidos pela tese jurídica no julgamento de casos repetitivos, mas que não são parte do caso (ou casos) a partir do qual a tese será firmada. Esses sujeitos interessados são denominados "sobrestados" ou "ausentes", a depender se são parte em um

\footnotetext{
${ }^{8}$ GALANTER, Marc. "Why the haves come out ahead? Speculations on the limits of legal change". Law and Society Review, v. 9, n. 1, p. 95-160, 1974. Republicação (com correções) em Law and Society. Dartmouth, Aldershot: Cotterrell, 1994, p. 165-230.
} 
processo já pendente ou se poderiam ser parte em processos futuros, aos quais a tese será também aplicada.

Partiu-se, então, das seguintes hipóteses a serem pesquisadas: (i) as técnicas de julgamento de casos repetitivos tendem a favorecer uma utilização mais estratégica por parte dos litigantes repetitivos; e (ii) os interesses dos "ausentes" e dos "sobrestados" são representados de forma deficiente (déficit de representatividade) no julgamento de casos repetitivos, mesmo quando há a intervenção de amicus curiae e/ou a realização de audiências públicas.

Para investigar essas perguntas e hipóteses, foi realizada tanto uma pesquisa teórica, quanto empírica sobre o tema, esta última desenvolvida em duas etapas.

A primeira etapa consistiu em um levantamento quantitativo jurisprudencial sobre questões submetidas a julgamento e teses jurídicas firmadas em sede de recurso especial repetitivo. Foi montado um banco de dados contendo todos os temas julgados pelo Superior Tribunal de Justiça (STJ) desde a entrada em vigor da Lei $n^{\circ}$ 11.672/2008 e que tiveram seu trânsito em julgado até 31.03.2017, para se extrair informações sobre (i) as partes envolvidas no recurso representativo da controvérsia; (ii) a questão subjetida a julgamento; (iii) o tribunal de origem; (iv) data de afetação, julgamento e trânsito em julgado; (v) informações sobre eventual audiência pública; e (vi) tese jurídica firmada. A partir desses dados, foi possível investigar as características dos casos submetidos, principalmente, se as teses firmadas favoreciam os interesses de litigantes repetitivos ou ocasionais, o que se mostrou essencial para endereçar a pergunta e hipótese de pesquisa atinente ao uso das técnicas de julgamento de casos repetitivos por litigantes com diferentes capacidades estratégicas.

Em seguida, foi desenvolvido um estudo de caso relativo ao julgamento, também pelo STJ, do tema $\mathrm{n}^{\mathrm{o}} 710$ sobre "a natureza dos sistemas de scoring e a possibilidade de violação a princípios e regras do Código de Defesa do Consumidor capaz de gerar indenização por dano moral", debatido em audiência pública realizada em 25.08.2014. Por meio da análise em profundidade de um caso específico, foi possível averiguar como se dá a participação dos litigantes repetitivos e ocasionais, dos "sobrestados" e dos "ausentes", desde a afetação do recursos representativo da controvérsia até o julgamento da tese jurídica, bem como do Ministério Público, Defensoria Pública, dos amici curiae e demais participantes da audiência pública.

Para facilitar a discussão sobre todos esses pontos, o trabalho foi dividido em três partes. 
A primeira teve como foco analisar os diferentes significados atribuídos ao acesso à justiça para se tentar chegar a algumas definições que pudessem amparar o desenvolvimento do estudo.

No Capítulo 1, investigou-se, inicialmente como a ideia de acesso à justiça esteve presente nos discursos acadêmicos e legislativos, identificando-se uma sensível mudança nos significados e na importância que lhe é atribuída. Também nesse capítulo é que foram identificados alguns dos fatores causadores ou propulsionadores da litigiosidade repetitiva, bem como o contexto e principais influências das reformas que culminaram na introdução dos mecanismos de julgamento de casos repetitivos no processo civil.

Ainda na Parte I, é no Capítulo 2 que se consolida a definição de acesso à justiça enquanto perspectiva metodológica e direito social, ratificando-se a importância dessa abordagem para o estudo do processo civil e para embasar as escolhas políticas atinentes à distribuição dos recursos necessários para se assegurar a realização do direito de acesso à justiça. Cuidou-se, também, da definição de litigantes ocasionais e repetitivos, a partir do referencial de Marc Galanter, e de como as reflexões do autor podem ser utilizadas para compreensão do atual cenário do Judiciário brasileira, em especial no tocante à litigiosidade repetitiva.

Na Parte II, foi discutida, essencialmente, a relação entre o acesso à justiça e o direito à participação no processo. O Capítulo 3 é dedicado, portanto, ao estudo do direito à participação enquanto elemento de legitimação do processo judicial e de seus resultados, bem como dos possíveis conflitos entre esse direito e outros valores também relevantes. Tratou-se, ainda, da substituição processual e do controle de representatividade adequada no âmbito da ação coletiva, para se discorrer sobre a excepcionalidade e os parâmetros que se colocam quando há uma mitigação do direito de participação no processo.

Já na Parte III, o Capítulo 4 discorre sobre as técnicas de julgamento de casos repetitivos, sempre com ênfase em aspectos atinentes à participação dos litigantes repetitivos, ocasionais e dos demais interessados. Sem a pretensão de exaurir todas as discussões atinentes a aplicação dessas técnicas, buscou-se tratar da sua natureza e objeto, dos efeitos da tese jurídica, da participação na instauração do procedimento e no julgamento da tese jurídica, bem como na recorribilidade das decisões proferidas e na revisão da tese jurídica a ser firmada. É importante pontuar que, embora este capítulo seja anterior à descrição dos resultados do estudo empírico, os dados já haviam sido levantados e analisados antes de sua redação final, o que permitiu articular as discussões teóricas com as reflexões decorrentes da pesquisa jurisprudencial e do estudo de caso realizados. 
O Capítulo 5 descreve a metodologia e os resultados do levantamento jurisprudencial relativo às teses jurídicas firmadas no julgamento de recursos especiais, enquanto o Capítulo 6 trata do estudo de caso acerca do julgamento da tese jurídica referente ao sistema de scoring de crédito, como mencionado.

$\mathrm{Na}$ conclusão, são retomados os principais pontos discutidos nas três partes do trabalho para consolidar as respostas às perguntas propostas e às hipóteses colocadas a partir das reflexões teóricas e constatações empíricas descritas ao longo do trabalho. 


\section{CONCLUSÃO}

Os dados apresentados na Introdução sobre litigiosidade e o volume de ações judiciais ajuizadas anualmente poderiam levar a crer que o objeto desta tese - o estudo de técnicas processuais e sua relação com o acesso à justiça - estaria ultrapassado ou descontextualizado. Afinal, do que adiantaria falar em "acesso à justiça" em um país em que já se tem processos demais? Não seria o "acesso à justiça" também o acesso a um Judiciário eficiente e célere?

Ainda que se verifique uma tendência de invisibilização ou de esvaziamento da pauta do acesso à justiça, sua importância está longe de ser superada. Afinal, a litigiosidade e o excesso de processos não se traduzem, necessariamente, em mais acesso à justiça ou, ainda, em uma participação efetiva de diferentes grupos e indivíduos no sistema de justiça. O que se vê no Judiciário hoje é "uma porta de entrada [que] atrai um tipo de litigante e desencoraja ou se fecha para a grande massa de indivíduos incapazes de manejar instrumentos de efetivação de seus direitos" ${ }^{\$ 85}$. A litigiosidade repetitiva é, justamente, a síntese desse paradoxo de um acesso à justiça mal distribuído, em que poucos utilizam o sistema recorrentemente, enquanto para outros a demanda é um contato apenas circunstancial com a justiça.

Assim, ao se problematizar a relação entre as técnicas processuais de julgamento de casos repetitivos e a noção de acesso à justiça, foi necessário definir com maior clareza o que se entende por "acesso à justiça".

Compreende-se que o acesso à justiça é um direito social a uma efetiva participação no sistema de justiça que viabilize o seu uso para promoção das transformações sociais necessárias para superação das desigualdades sociais, de raça, gênero, orientação sexual, etc., persistentes em nossa sociedade. Além disso, é também uma perspectiva metodológica pela qual são priorizados métodos empíricos e de análises comparativas para investigação das experiências de diferentes grupos e indivíduos no sistema de justiça e os impactos sociais da atuação de seus agentes e instituições. Essa abordagem é necessária para embasar as escolhas distributivas necessárias para efetivação do acesso à justiça ou, em outras palavras, para assegurar acesso a quem não tem (ou pouco tem), ainda que isso implique em reduzir o acesso a quem já muito o tem.

${ }^{685}$ SADEK, Maria Thereza, 2014, op. cit., p. 60. 
Adotando-se a noção de acesso à justiça enquanto direito social e abordagem metodológica para estudar uma técnica processual, tem-se por necessário investigar as formas de participação e a experiência dos diferentes sujeitos, bem como os impactos de sua aplicação. A partir do referencial teórico de Marc Galanter e da tipologia de litigantes habituais e ocasionais ${ }^{686}$, foi possível aprofundar no estudo das vantagens estratégicas atribuídas àqueles que utilizam o sistema de justiça de forma mais recorrente e em ações similares, algo próprio da dinâmica da litigiosidade repetitiva.

Não se pode afastar a importância da participação das partes do caso paradigma ou, ainda, dos interessados, sob o argumento de que a tese jurídica conformaria, em verdade, um precedente. As técnicas de julgamento de casos repetitivos acarretam uma formação provocada de uma tese jurídica, com o intuito de otimizar a prestação jurisdicional, o que é marcadamente diferente do precedente, que surge naturalmente em decorrência da autoridade de sua ratio decidendi. Justamente em razão do intuito gerencial dessas técnicas, a tese jurídica consiste em um enunciado normativo autônomo, a ser aplicado de forma padronizada, e não a partir da aproximação do arcabouço fático do caso paradigma (os quais sequer estão registrados no enunciado) e aqueles do caso concreto.

Esse direito de participação não é, em verdade, absoluto, sendo colocado em constante conflito com outros valores, como a própria duração razoável do processo. Ainda assim, limitações ao seu exercício devem ser excepcionais, dada a sua essencialidade tanto como elemento de legitimação da atividade jurisdicional, quanto de seus resultados. Do ponto de vista da efetivação do direito de acesso à justiça, uma mitigação ao direito de participar somente se justificaria diante de uma efetiva possibilidade de se desestabilizar a desigualdade entre as partes, realizando-se, com isso, o potencial distributivo do processo.

Nesse sentido, é necessário problematizar como se dá a participação dos destinatários da tese jurídica considerando as suas diferentes capacidades de influir na sua formação. Isso porque a definição da tese se dá em um julgamento de casos paradigmas em que se tem, de um lado, um ou alguns litigantes habituais, com mais recursos e vantagens estratégicas e, de outro, litigantes ocasionais, para quem a participação é muito mais custosa e circunstancial. Quanto aos "sobrestados" e "ausentes", não há uma preocupação clara com a sua participação direta ou com a representatividade de seus interesses no julgamento da tese jurídica, o que é agravado diante da possibilidade de esses interesses serem representados, na

${ }^{686}$ GALANTER, Marc, 1974, op. cit. 
prática, por litigantes ocasionais, que possuem menor capacidade técnica e maiores dificuldades de se articular entre si.

Quanto à disparidade estratégica entre os diferentes atores, colocou-se questão sobre como os litigantes repetitivos e litigantes ocasionais utilizam e como são afetados pela utilização dessas técnicas. A esse respeito, alguns pontos discutidos ao longo da pesquisa teórica e do estudo empírico corroboram com a hipótese de que o IRDR os recursos repetitivos podem ser utilizados de forma mais estratégica por litigantes habituais do que ocasionais.

Primeiramente, em sendo assente que a apreciação de questões de direito não é possível de ser feita de forma totalmente desatrelada de um substrato fático, mesmo que se sustente que a tese jurídica seja formulada a partir de uma "situação-modelo", caberá as partes dos casos paradigma um papel essencial na reconstrução desse cenário fático, em toda a sua complexidade. Isso é especialmente pertinente no âmbito da litigiosidade repetitiva, em que são discutidas questões de grandes repercussões econômicas, sociais e políticas.

Ratificando-se, então, a importância dos elementos subjetivos e objetivos do caso paradigma e da participação das partes no julgamento da tese jurídica, tem-se que a falta de critérios claros de escolha do caso paradigma é prejudicial aos litigantes ocasionais, que poderão se ver incumbidos de representar os interesses de uma vasta gama de interessados, sem que tenham se arrogado a esse papel. Além disso, no caso do IRDR, os litigantes habituais conseguem traçar estratégias e se articular entre si para fomentar a instauração do incidente em casos e em teses que lhes sejam estrategicamente pertinentes.

Com relação às evidências empíricas, tem-se que, na maior parte das teses jurídicas firmadas em sede de julgamento de recursos especiais repetitivos, os litigantes habituais eram recorrentes, ou seja, estavam, até então, sendo vencidos. Ainda, no quadro geral e em todas as temáticas específicas os litigantes habituais obtiveram maior êxito. Mesmo que se possa arguir que o percentual de teses favoráveis aos interesses desses litigantes não seja tão significativo, ao articular esses dados é que se infere que os litigantes habituais conseguem, de modo consideravelmente mais exitoso, reverter entendimentos que não eram favoráveis a seus interesses.

Olhando não só para os resultados obtidos, mas também para a participação do litigantes habituais no procedimento em si, verificou-se no estudo de caso que estes foram capazes de atuar de forma estratégica para pleitear conjuntamente a desistência de todos os recursos afetados para julgamento e para apresentar na audiência pública dados técnicos e econômicos acerca do caso, de forma concatenada, também, com amici curiae que 
representavam interesses convergentes com os seus. Esses dados foram particularmente influentes no julgamento da tese.

Com relação à pergunta sobre como se dá a participação e a representação dos interesses dos destinatários da tese jurídica, conjecturou-se que os interesses das partes dos processos pendentes ou futuros ("sobrestados" e "ausentes") são representados de forma deficiente (déficit de representatividade) no julgamento de casos repetitivos, mesmo quando há a intervenção de amicus curiae e/ou a realização de audiências públicas.

Nesse sentido, tem-se que as partes dos casos paradigma acabam tendo um papel relevante na reconstrução da "situação-modelo" ou do o arcabouçou fático a partir do qual as questões jurídicas deverão ser apreciadas, além de um espaço mais significativo de participação no julgamento da tese jurídica do que os demais interessados. Acabam, assim, representando os interesses dos "sobrestados" e dos "ausentes", ainda que não tenham se arrogado a esse papel ou tenham condições de exercê-lo, em uma atuação que pode ser até mesmo mais decisiva que aquela dos representantes adequados da ação coletiva, visto que a tese jurídica poderá ser aplicada inclusive pro et contra àqueles que não participaram do seu julgamento.

Essa situação é agravada pelo fato de que se tem, de um lado, um litigante com mais recursos e maior capacidade de se articular com os demais sujeitos com quem seus interesses convergem e, de outro, os litigantes ocasionais dos casos paradigma, que não conseguirão representar com as mesmas condições os interesses daqueles que defendem posições jurídicas similares as suas.

Novamente recorrendo aos achados empíricos, tem-se que, no caso estudado, os interesses dos litigantes ocasionais foram adequadamente representados pelas partes do caso paradigma, dada a capacidade técnica de seus representantes legais, sua especialidade e proximidade com os fatos do caso. No entanto, mesmo assim, foram sensíveis as vantagens estratégicas obtidas pelos litigantes repetitivos a partir do momento em que as questões passaram a ser discutidas em sede de recurso especial repetitivo. Por essa sistemática, foi dada significativa importância aos argumentos técnicos e de autoridade (mais do que às provas e demais alegações suscitadas ao longo do julgamento dos casos paradigma), aos quais os litigantes ocasionais não tinham acesso, ou capacidade de fazer frente.

Assim, pode se concluir que, embora seja possível se pensar em algum tipo de controle de representatividade adequada no âmbito do julgamento dos casos repetitivos embasado em critérios similares aos utilizados nas ações coletivas, como capacidade técnica e proximidade e envolvimento com os fatos do caso - este não será suficiente para se promover 
uma reorganização estratégica dos litigantes ocasionais, a ponto de se justificar restrições ao direito de participação direta dos "sobrestados" e dos "ausentes". Casos repetitivos versam sobre matérias de grande repercussão social e econômica, e são dirimidos em julgamentos realizados por órgãos de cúpula do Judiciário, onde o acesso, a expertise e a capacidade estratégica dos grandes litigantes se fazem particularmente influentes e vantajosos. Em outras palavras, nessa sistemática processual, os "representantes adequados" dos litigantes repetitivos tendem a ser mais bem sucedidos do aqueles dos litigantes ocasionais.

Enfim, poderia se dizer que os mecanismos de ampliação da participação, como a intervenção do amicus curiae e a audiência pública, seriam efetivos na representação dos interesses dos "sobrestados" e "ausentes" no julgamento dos casos repetitivos.

Essas formas de ampliação do debate e da diversidade de argumento são, sem dúvida, importantes para aprimorar a qualidade das decisões que firmam teses jurídicas em sede de julgamento de casos repetitivos. Entretando, não se pode afirmar que os amici sejam capazes de representar, efetiva e adequadamente, os interesses desses terceiros, especialmente se estes forem litigantes ocasionais em processos sobrestados ou mesmo em demandas futuras.

Litigantes habituais podem ter mais fácil acesso à especialistas tanto do meio jurídico como não jurídico, bem como recursos para financiar o levantamento de informações (econômicas, técnicas, estatísticas, etc.) que poderão ser apresentadas por eles próprios ou por entidades que representem seus interesses, seja como amicus curiae, seja na audiência pública.

No estudo de caso realizado, verificou-se um predomínio de entidades representativas de interesses dos litigantes habituais e, também, de defesa dos direitos do consumidor. No entanto, a análise dos argumentos discutidos e da decisão firmada demonstram que os elementos técnicos, especialmente acerca do funcionamento do sistema por parte das empresas que o disponibilizam no mercado, foram decisivos para julgamento da tese, acarretando, inclusive, uma sensível mudança no posicionamento até então adotado pelo tribunal de origem sobre a matéria.

Com relação ao Ministério Público e a Defensoria Pública, muito embora possam, em tese, atuar de forma mais estratégica do que os litigantes ocasionais, não se pode presumir a sua capacidade de representar os interesses destes. Isso porque, diferentemente de quando atuam como legitimados extraordinários nas ações coletivas, tais instituições não possuem, necessariamente, uma proximidade o arcabouço fático do caso, tampouco com os atingidos. São chamados a intervir apenas no julgamento da tese jurídica, e não no curso do caso 
paradigma, e nem são instados a se articular com os "sobrestados" e "ausentes" para representar seus interesses nos debates perante o órgão julgador.

Há outro ponto fundamental que é o de que, nem sempre, haverá um alinhamento de interesses entre o Ministério Público, a Defensoria Pública e os amici curiae, e os "sobrestados" e "ausentes". Foi o que se verificou claramente no estudo de caso, em que o Ministério Público e a maioria das entidades que interviu no processo não defendeu as mesmas teses e argumentos do que os advogados dos litigantes ocasionais do caso paradigma e de outros casos sobrestados. Novamente, fica claro que a participação dessas instituições e intervenientes não pode substituir a participação dos "sobrestados" e "ausentes", que deverá ser fomentada, e não obstada, para se promover uma verdadeira ampliação do debate acerca da tese jurídica.

$\mathrm{Na}$ tentativa de se resumir todas essas colocações, deixa-se, como observação final, que as técnicas de julgamento de casos repetitivos não podem ignorar a importância de se pensar constantemente sobre acesso à justiça e sobre o direito de participar no processo, o que implica em reconhecer que o processo é utilizado por usuários com diferentes capacidades estratégicas. Especialmente no âmbito da litigiosidade repetitiva, não se pode ignorar essa dinâmica existente entre as partes, sob o risco de que a promoção da eficiência e da segurança jurídica tenha como preço a acentuação da desigualdade já existente entre aqueles que tem e aqueles que não tem. Não se nega que a busca pela eficiência e pela duração razoável do processo também são, sem dúvida, valores relevantes. Mas do que adiante se ter um Judiciário eficiente que seja excessivamente utilizado por alguns, e ainda distante e de difícil acesso para outros?

Os mecanismos processuais existentes e aqui estudados certamente não são suficientes para alterar ou reverter essa dinâmica, cabendo refletir se, de fato, a solução para a litigiosidade repetitiva reside mesmo na esfera do direito processual. Mais do que aperfeiçoar ou intensificar o uso dessas técnicas, seria necessário dar alguns passos para trás para se suprir o já indicado déficit de estudos sobre litigiosidade repetitiva, reconhecendo esta como uma realidade social complexa, cujas causas e características ainda não são plenamente compreendidas. Ao se resgatar a perspectiva metodológica do acesso à justiça, talvez seja possível caminhar para um entendimento mais aprofundado e crítico a respeito, para então ser possível, verdadeiramente, aproximar o processo civil dessa realidade.

Por fim, cabe alertar que a litigiosidade repetitiva é também uma realidade social em constante mudança, e que vem se moldando a largos passos aos avanços tecnológicos impactam as profissões e instituições jurídicas. Se antes se falava em meios de se reproduzir 
automaticamente peças processuais e decisões judiciais, já é presente o uso de inteligência artificial para construção e aperfeiçoamento de teses jurídicas, bem como para obtenção de dados de jurimetria tanto do lado dos litigantes, quanto das instituições judiciárias. Em breve, não se discutirão mais os problemas decorrentes da padronização decisória, mas sim dos algoritmos utilizados para prolação das decisões jurídicas, levando a uma verdadeira ressignificação do próprio conceito de justiça e da função de todos os profissionais do sistema de justiça.

Quais serão os impactos desses avanços tecnológicos em termos de acesso à justiça? Quem terá acesso a essa tecnologia e "sairá na frente"? Como esse acesso impactará na massificação da litigiosidade repetitiva, no barateamento dos serviços jurídicos e na dinâmica entre litigantes repetitivos e ocasionais? Esses temas certamente serão (e já são) extremamente candentes, e demonstram, claramente, a importância de não se encarar o acesso à justiça como pauta ultrapassada. 


\section{BIBLIOGRAFIA}

ABBOUD, Georges; CAVALCANTI, Marcos de Araújo. "Inconstitucionalidade do Incidente de Resolução de Demandas Repetitivas (IRDR) e os riscos ao sistema decisório" In Revista de Processo, vol. 240, fev./2015, 2015, p. 221-242.

; STRECK, Lenio Luiz. "O solilóquio epistêmico do ministro Roberto Barroso sobre precedentes". Conjur, 3 nov. 2016. Disponível em $<$ http://www.conjur.com.br/2016nov-03/senso-incomum-soliloquio-epistemico-ministro-barroso-precedentes $>$, acesso em 15 mai. 2017.

ALMEIDA, Eloisa Machado. Amicus Curiae no Supremo Tribunal Federal. Tese de Doutorado. Faculdade de Direito da Universidade de São Paulo: São Paulo, 2015.

. "O amicus curiae na jurisprudência do Supremo Tribunal Federal". Revista Brasileira de Estudos Constitucionais”. № 24, Belo Horizonte: Forum, 2012, p. 1073-1098.

. Sociedade civil e democracia: a participação da sociedade civil como amicus curiae no Supremo Tribunal Federal. Dissertação de mestrado. Pontifícia Universidade Católica de São Paulo, 2006.

ALMEIDA, Frederico de; CUNHA, Luciana Gross; "Justiça e desenvolvimento econômico na reforma do judiciário". Trabalho apresentado no evento Direito e Desenvolvimento: um diálogo entre os BRICs. São Paulo: DIREITO GV, Universidade de Winsconsin e ABDI, nov. 2010.

ALVIM, Teresa Arruda. "CPC abre debate sobre alcance de suspensão de ações em repetitivos". Conjur. Edição de 11 jun. 2017. Disponível em https://www.conjur.com.br/2017jun-11/teresa-alvim-cpc-abre-debate-suspensao-acoes-repetitivos, acesso em 8 dez. 2017.

ANDREWS, Neil. "Multi-Party Proceedings in England: Representative and Group Actions". Duke Journal of Comparative \& International Law. Vol. 11, n. 2, 2001, p. 249-267.

ARANTES, Rogério Bastos. "Direito e Política: o Ministério Público e a defesa dos direitos coletivos". Revista brasileira de ciências sociais, v. 14, n. 39, p. 83-102, 1999.

ARENHART, Sérgio Cruz. "Decisões Estruturais no Direito Processual Civil Brasileiro". Revista Magister de Direito Civil e Processual Civil, Porto Alegre, v. 10, n. 59, p. 67-85, mar./abr. 2014.

ASSOCIAÇÃO DOS MAGISTRADOS BRASILEIROS. O uso da Justiça e o litígio no Brasil. Coord. Sérgio Luiz Junkes. Coord. Científica Maria Tereza Sadek. Disponível em: http://s.conjur.com.br/dl/uso-justica-litigio-brasil-pesquisa-amb.pdf. Acesso em 05 de julho de 2016.

ASPERTI, Maria Cecília de Araujo; COSTA, Susana Henriques da; GABBAY, Daniela Monteiro. "Acesso à justiça no Brasil: reflexões sobre escolhas políticas e necessidade de 
construção de uma nova agenda". Artigo apresentado na conferência Law and Society de 2017. No prelo.

; GARROTE, Marina G.; TOCANTINS, Matheus C. "The tortuous path for changing name and gender: the challenges faced by transgender people in Brazilian Courts". Artigo apresentado na conferência Law and Society de 2017. No prelo.

; COSTA, Susana Henriques da; GABBAY, Daniela Monteiro; SILVA, Paulo Eduardo Alves da; "Why the 'Haves' come out ahead in Brazil? Revisiting speculations concerning repeat players and one-shooters in the Brazilian litigation setting". FGV Direito SP Research Paper Series No 141. Jan./2016. São Paulo: FGV, 2016.

"Meios consensuais de resolução de disputas repetitivas: a mediação, a conciliação e os grandes litigantes do Judiciário". Dissertação de mestrado defendida na Faculdade de Direito da Universidade de São Paulo. São Paulo: 2014.

BAETGE, Dietmar. "Germany". Class Actions, Group Litigation \& Other Forms of Collective Litigation. v. 15, 2014. Disponível em $<\mathrm{http} / / / \mathrm{www}$. law. Stanford. edu/display/images/dynamic/events_media/Germany_National_Report. pdf $>$, acesso em 07 dez. 2017.

BANDEIRA, Regina Maria Groba. A Emenda Constitucional $n^{\circ} 45$, de 2004: o novo perfil do Poder Judiciário brasileiro. Brasília: Câmara dos Deputados, 2005. Disponível em http://bd.camara.gov.br/bd/handle/bdcamara/1587, acesso em 8 set. 2017.

BANNER, Stuart. "The myth of the neutral amicus: American courts and their friends", 17901890. Constitucional Commentary, v. 20, p. 111, 2003

BASTOS, Antonio Adonias Aguiar. O devido processo legal nas demandas repetitivas. Tese de Doutorado. Universidade Federal do Estado da Bahia: 2012.

. "Situações jurídicas homogêneas: um conceito necessário para o processamento das demandas de massa". Revista de Processo. n. 186, v. , 2010, p. 87-107.

BERTÃO, Naiara. "Funções típicas de advogados já são feitas por softwares e robôs". Exame. 20 jan. 2017. Disponível em https://exame.abril.com.br/revista-exame/deixa-que-o-roboresolve/\#, acesso em 25 set. 2017.

BRASIL. Parecer da Comissão Especial da Câmara dos Deputados ao Projeto de Lei n. 6.025, de 2005, ao Projeto de Lei n. 8.046, de 2010, ambos do Senado Federal, e outros, que tratam do "Código de Processo Civil” (revogam a lei no 5.869, de 1973). Brasília: 2012.

. Anteprojeto do Novo Código de Processo Civil. Projeto de Lei n. 8.046, de 2010, do Senado Federal, que trata do Novo Código de Processo Civil. Brasília: 2010.

Congresso. Justificativa ao Projeto de Lei $\mathrm{n}^{\mathrm{o}} 1.213 / 2007$, submetido pelo Ministério da Justiça à Câmara dos Deputados em 28 de maio de 2007.

Pacto de estado em favor de um judiciário mais rápido e republicano. Dez. 2004. 
. Congresso. Câmara dos Deputados. Parecer da Comissão Especial da Câmara dos

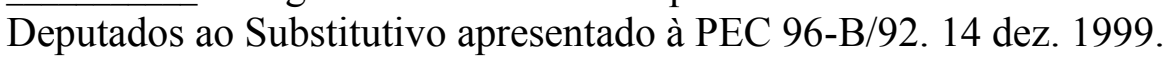

Ata da $4^{\mathrm{a}}$ Reunião Ordinária, realizada em 15.04.1987, da Comissão da Organização e Sistema de Governo. Assembléia Nacional Constituinte (Atas de Comissões). Disponível em http://www.senado.leg.br/publicacoes/anais/constituinte, acesso em 1 set. 2017.

BRESOLIN, Umberto. "Considerações sobre o Artigo 285-A do Código de Processo Civil” In CARMONA, Carlos Alberto. Reflexões sobre a Reforma do Código de Processo Civil Estudos em homenagem a Ada Pellegrini Grinover, Cândido Rangel Dinamarco e Kazuo Watanabe. São Paulo: Atlas, 2007.

BRITTO, Adriana (org.). II Relatório Nacional de Atuações Coletivas da Defensoria Pública. Associação Nacional dos Defensores Públicos. Brasília: ANAPED, 2015. Disponível em https://www.anadep.org.br/wtksite/Preview_Livro_Defensoria_II_Relat_rio(1).pdf, acesso em 11 out. 2017.

BUENO, Cassio Scarpinella. Amicus curiae no processo civil brasileiro: um terceiro enigmático. $3^{\text {a }}$ Edição. São Paulo: Saraiva, 2012.

"Réquiem para a ação civil pública". Disponível em http://www.scarpinellabueno.com/cat-para-ler/62-25-requiem-para-a-acao-civil-publica.html, acesso em 31 ago. 2017. Publicado originalmente em FIUZA, César Augusto de Castro; DE SÁ, Maria de Fátima; DIAS, Ronaldo Brêtas C. (coord.). Temas atuais de direito processual civil. Belo Horizonte: Del Rey, 2001, páginas 49-72.

BURGO, Vitor. "Em busca da legitimação perdida: a exclusão da pessoa física do rol de legitimados do PL 5.139/2006" In GOZZOLI, Maria Clara (coord.). Em defesa de um novo sistema de processos coletivos: estudos em homenagem a Ada Pellegrini Grinover. São Paulo: Saraiva, 2010, p. 679-704.

CABRAL, Antonio do Passo. "A escolha da causa-piloto nos incidentes de resolução de processos repetitivos" In DIDIER JR., Fredie; CUNHA, Leonardo Carneiro da. Julgamento de casos Repetitivos. Coleção Grandes Temas do Novo CPC. Vol. 10. Salvador: JusPodium, 2017, p. 37-64.

"A causa de pedir nas ações coletivas" In SOUSA, José Augusto Garcia de. (coord.). A Defensoria Pública e os Processos Coletivos. Rio de Janeiro: Lumen Juris, 2008.

CAIN, Kevin G. "The McDonald's Coffee Lawsuit". Journal of Consumer \& Commercial Law, v. 11, n. 1, 2007.

CANÁRIO, Pedro. "Quase 110 milhões de processos passaram pelo Judiciário em 2016, segundo CNJ". Conjur. 4 set. 2017. Acesso em https://www.conjur.com.br/2017-set-04/110milhoes-processos-passaram-judiciario-2016, acesso em 20 dez. 2017; "Explosão de litigiosidade exige mudanças no Judiciário, afirma Ricardo Lewandowski”. Notícias STF. 20 nov. $2014 . \quad$ Disponível em http://www.stf.jus.br/portal/cms/verNoticiaDetalhe.asp?idConteudo=280214, acesso em 20 dez. 2017. 
CAPPELLETTI, Mauro. "Formações sociais e interesses coletivos diante da justiça civil". Trad. CAMPOS, Nelson Renato Palaia Ribeiro de. Revista de Processo, v. 2, n. 5, jan./mar., 1977, p. 128-159.

; GARTH, Bryant, Access to Justice: a world survey. Sijthoff and Noordhoff Alphenaanderijn Dott. A. Giuffrè Editore: Milão, 1978a.

; GARTH, Bryant. "Access to Justice: The Newest Wave in the Worldwide Movement to Make Rights Effective”. Buffalo Law Review, 27, n. 181, 1978b, p. 181-292.

Fabris, 1988 .

; GARTH, Bryant G. Acesso à justiça. Trad. Ellen Gracie Northfleet. Porto Alegre:

"Constitucionalismo moderno e o papel do Judiciário na sociedade contemporânea". Revista de Processo. v. 15, n. 60, out./dez., 1990, p. 110-117.

. "Os métodos alternativos de solução de conflitos no quadro do movimento universal de acesso à justiça”. Revista de Processo, vol. 74 (abril-junho de 1994), p. 82-97.

CARDOSO, Maurício; VASCONCELLOS, Marcos de. "Com robôs, escritório atua em mais de 360 mil processos com 420 advogados". Conjur. 5 mar. 2016. Disponível em https://www.conjur.com.br/2016-mar-05/robos-escritorio-atua-360-mil-processos-420advogados, acesso em 10 out. 2017.

CARDOSO, Evorah. "Ciclo de vida do Litígio Estratégico no Sistema Interamericano de Direitos Humanos: dificuldades e oportunidades para atores não estatais". Revista Electrónica del Instituto de Investigaciones Ambrosio L. Gioja. Año V. Número Especial, 2011, p. 363378.

CASAGRANDE, Cássio. Ministério Público e judicialização da política: estudos de casos. Porto Alegre: Sérgio A. Fabris, 2008.

CHAYES, Abram "The role of the judge in public law litigation". Harvard Law Review. n. 89, maio-1976, p. 1281-1316.

CINTRA, Antonio Carlos de Araújo; GRINOVER, Ada Pellegrini; DINAMARCO, Cândido Rangel. Teoria Geral do Processo. 30 Ed. São Paulo: Malheiros, 2014.

CONECTAS DIREITOS HUMANOS. Tortura blindada: como as instituições do sistema de justiça perpetuam a tortura nas audiências de custódia. São Paulo: Conectas, 2017

CONSELHO NACIONAL DE JUSTIÇA. Justiça em Números 2017 (ano-base de 2016). Disponível em <http://www.cnj.jus.br/programas-e-acoes/pj-justica-em-numeros>, acesso em 8 set. 2017.

. 100 Maiores Litigantes. Brasília: Departamento de Pesquisas Judiciária, 2012. . 100 Maiores Litigantes. Brasília: Departamento de Pesquisas Judiciária, 2011. 
COSTA, Susana Henriques da. "A representação adequada e litisconsórcio - o Projeto de Lei n. 5.139/2009" In GOZZOLI, Maria Clara (coord.). Em defesa de um novo sistema de processos coletivos: estudos em homenagem a Ada Pellegrini Grinover. São Paulo: Saraiva, 2010, p. 619-642.

. O processo coletivo na tutela do patrimônio e da moralidade administrativa. São Paulo: Quartier Latin, 2009a.

. "O controle judicial da representatividade adequada: uma análise dos sistemas norte-americano e brasileiro" In SALLES, Carlos Alberto de. As grandes transformações do processo civil brasileiro: homenagem ao Professor Kazuo Watanabe. São Paulo: Quartier Latin, 2009b, p. 953-978.

CUNHA, Leonardo José Carneiro da, "Primeiras impressões sobre o art. 285-A do CPC julgamento imediato de processos repetitivos: uma racionalização para as demandas de massa”. Revista Dialética de Direito Processual. n 39, jun-2006, p. 93-104.

. "Anotações sobre o incidente de resolução de demandas repetitivas previsto no projeto do novo código de processo civil”. Revista de Processo. São Paulo, v. 193, mar./2011.

CUNHA, Luciana Gross; OLIVEIRA, Fabiana Luci de. "Medindo o acesso à Justiça Cível no Brasil. Opinião Pública. Campinas. V. 22, n. 2, agosto 2016, p. 315-347.

CUNHA, Luciana Gross. Juizado Especial: criação, instalação, funcionamento e a democratização do acesso à justiça. São Paulo: Saraiva, 2008

; GABBAY, Daniela Monteiro (Coords.). Litigiosidade, morosidade e litigância repetitiva: uma análise empírica. São Paulo: Saraiva, 2013. (Série Direito e Desenvolvimento).

DAKOLIAS, María, The Judicial Sector in Latin America and in the Caribbean: elements of reform. Documento Técnico para o Banco Mundial n. 319S. Washington D.C: World Bank, 1997.

DANTAS, Karoline Tarciane de Barros Campos. Jurisdição Constitucional e Audiências Públicas: um instrumento a favor da democracia? Dissertação de Mestrado. Universidade Católica de Pernambuco. Recife, 2014.

DESTEFENNI, Marcos. "Eficácia expandida da coisa julgada individual". Disponível em < http://estadodedireito.com.br/eficacia/>, acesso em 10 de maio de 2017.

DIDIER JR., Fredie. Curso de Direito Processual Civil. Vol. 1. $18^{\text {a }}$ Ed. Salvador: Juspodium, 2016.

; BRAGA, Paula Sarno; OLIVEIRA, Rafael Alexandria de. Curso de direito processual civil, Vol. 2. $11^{\text {a }}$ Ed., Salvador: Juspodium.

; CUNHA, Leonardo Carneiro da. Curso de Direito Processual Civil. Vol. 3. $13^{\mathrm{a}}$ Ed. Salvador: Juspodium, 2017. 
; ZANETI JR., Hermes. "Ações coletivas e o Incidente de Julgamento de casos repetitivos" In DIDIER JR., Fredie (coord.). Julgamento de Casos Repetitivos. Col. Grandes Temas do Novo CPC. Salvador: Juspodium, 2017, p. 181-191.

; "Apontamentos para a concretização do princípio da eficiência do processo" In Novas Tendências do Processo Civil - Estudos sobre o Projeto do Novo CPC. FREIRE, Alexandre; NUNES, Dierle; DIDIER Jr., Fredie; MEDINA, José Miguel Garcia; FUX, Luiz; CAMARGO, Luiz Henrique Volpe; OLIVEIRA, Pedro Miranda de. Salvador: Juspodium, 2015.

DINAMARCO, Cândido Rangel. Instituições de Direito Processual Civil. Vol. II, $7^{\text {a }}$ Edição. São Paulo: Malheiros, 2017.

Execução civil. $7^{\mathrm{a}}$ Edição, São Paulo: Malheiros, 2000.

FALCÃO NETO, Joaquim de Arruda. "Cultura Jurídica e Democracia: a favor da democratização do Judiciário" In LAMOUNIER et al (org.). Direito, Cidadania $e$ Participação. São Paulo: T. A. Queiroz, 1980, p. 4-19.

FARIA, Adriana Ancona; GHIRARDI, José Garcez; FEFERBAUM, Marina. "O financiamento estudantil federal nos cursos jurídicos brasileiros". Observatório do Ensino do Direito. Vol. 2, n. 2. São Paulo: FGV, 2015. Disponível em http://direitosp.fgv.br/sites/direitosp.fgv.br/files/arquivos/relatorio_observatorio_do_ensino_d o_direito__ vol 2 2 n 2.pdf, acesso em 26 ago. 2017.

FAZZALARI, Elio. Istituzioni di diritto processuale. Padova: CEDAM, 1994.

FERRAZ, Leslie Shérida. Acesso à justiça: uma análise dos Juizados Especiais Cíveis no Brasil. Rio de Janeiro: Editora FGV, 2010.

FISS, Owen. Direito como Razão Pública: processo, jurisdição e sociedade. Coord. trad. Carlos Alberto de Salles. Trad. Daniel Porto Godinho; Melina de Medeiros Rós. Maria Cecilia de Araujo Asperti. 2a Ed. revista e atualizada. São Paulo: Juruá, 2017.

. "As Formas de Justiça” In Direito como Razão Pública: processo, jurisdição e sociedade. Coord. trad. Carlos Alberto de Salles. Trad. Daniel Porto Godinho; Melina de Medeiros Rós. Maria Cecilia de Araujo Asperti. $2^{\mathrm{a}}$ Ed. revista e atualizada. São Paulo: Juruá, 2017, p. 21-80.

. "Contra o Acordo" In Direito como Razão Pública: processo, jurisdição e sociedade. Coord. trad. Carlos Alberto de Salles. Trad. Daniel Porto Godinho; Melina de Medeiros Rós. Maria Cecilia de Araujo Asperti. $2^{\mathrm{a}}$ Ed. revista e atualizada. São Paulo: Juruá, 2017, p. 143-150.

. "As bases políticas e sociais da adjudicação" In Direito como Razão Pública: processo, jurisdição e sociedade. Coord. trad. Carlos Alberto de Salles. Trad. Daniel Porto Godinho; Melina de Medeiros Rós. Maria Cecilia de Araujo Asperti. 2a Ed. revista e atualizada. São Paulo: Juruá, 2017, p. 81-93. 
. "A teoria política das ações coletivas" In Direito como Razão Pública: processo, jurisdição e sociedade. Coord. trad. Carlos Alberto de Salles. Trad. Daniel Porto Godinho; Melina de Medeiros Rós. Maria Cecilia de Araujo Asperti. 2 ${ }^{\mathrm{a}}$ Ed. revista e atualizada. São Paulo: Juruá, 2017, p. 185-198.

FRAGA, Vitor. "Remuneração irrisória de audiencistas será pauta de debates no dia 21 ". Tribuna do advogado. Out/2013. Disponível em $<$ http://www.oabrj.org.br/materia-tribuna-doadvogado/17876-Remuneracao-irrisoria-de-audiencistas-sera-pauta-de-debates-dia-21>, acesso em 14 jul. 2017.

FRASER, Nancy. "Social Justice in the Age of Identity Politics: Redistribution, Recognition, and Participation". The Tanner Lectures on Human Values. Stanford University: 1996.

FREITAS, Graça Maria Borges. "Reforma do Judiciário, o discurso econômico e os desafios da formação do magistrado hoje". Revista do Tribunal Regional do Trabalho da $3^{a}$ Região. Belo Horizonte, v.42, n.72, jul./dez.2005, p. 31-44.

GABBAY, Daniela Monteiro; RAMOS, Luciana; SICA, Lígia Pinto. "Corporate Law Firms: The Brazilian Case". Paper apresentado no evento The Brazilian Legal Profession in the Age of Globalization. 10 nov. 2015. Disponível em http://direitosp.fgv.br/evento/brazilian-legalprofession-age-globalization, acesso em 19 dez. 2017.

GALANTER, Marc. "Acesso à justiça em um mundo de capacidades em expansão". Revista Brasileira de Sociologia do Direito. Porto Alegre: ABraSD, v. 2, n. 1, p. 37-49, jan./jun., 2015, p. 37-49.

- Por que 'quem tem' sai na frente: especulações sobre os limites da

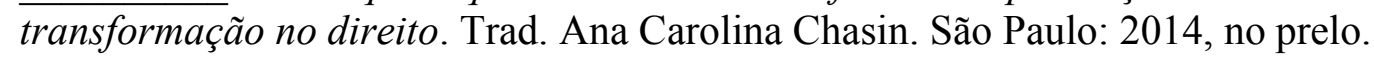

. "Access to Justice in a World of Expanding Social Capability". Fordham Urban Law Journal. Vol. 37, issue 1, 2009.

. "Planet of the Aps: reflections on the scale of law and its users", 53 Buffalo Law Review, 2006, pp. 1369-1417.

. "The Hundred Year Decline of Trials and the thirty years war". Stanford Law Review, v. 57, n. 1255, Stanford University Press: 2005.

. "The Vanishing Trial: an examination of trials and related matters in Federal and State Courts”. Journal of Empirical Legal Studies, v. 1, n. 459, 2004.

. "An Oil Strike in Hell: Contemporary Legends about the Civil Justice System". Arizona Law Review. Vol. 40, 1998, p. 717-752.

. "Why the haves come out ahead? Speculations on the limits of legal change". Law and Society Review, v. 9, n. 1, p. 95-160, 1974. Republicação (com correções) em Law and Society. Dartmouth, Aldershot: Cotterrell, 1994, p. 165-230.

GRECO, Leonardo. "Garantias fundamentais do processo: o processo justo". Novos estudos jurídicos, v. 7, n. 14, 2008. 
GRINOVER, Ada Pellegrini. "As garantias constitucionais do processo nas ações coletivas" In Revista de Processo, v. 11, n. 43 (jul./set. 1986), p. 19-30.

. "Direito processual coletivo". GRINOVER, Ada Pellegrini; MENDES, Aluisio Gonçalves de; WATANABE, Kazuo. Direito Processual Coletivo e o Anteprojeto do Código Brasileiro de Processos Coletivos. São Paulo: RT, 2007, p 11-15.

"Novas questões sobre a legitimação e a coisa julgada nas ações coletivas" In $O$ processo - estudos e pareceres. $2^{\mathrm{a}}$ ed. São Paulo: DPJ, 2009, p. 266-278.

. “A coletivização de ações individuais após o veto" In MILARÉ, Édis (Coord.). Ação civil pública após 30 anos. São Paulo: Revista dos Tribunais, 2015, p. 19-24.

GROSSMAN, Lews A. "The Story of Parklane: the litigation crisis and the efficiency imperative" In CLERMONT, Kevin M. (ed.). Civil Procedure Stories, 2008, p. 405-443.

GUIMARÃES, Amanda de Araújo. Incidente de Resolução de Demandas Repetitivas. São Paulo: Dissertação de Mestrado. Faculdade de Direito USP: 2017.

HAZARD JR., Geoffrey C. "Preclusion as to issues of law: The Legal System's Interest". Iowa Law Review, n. 70, v. 87, 1984-1985.

INSTITUTO DE PESQUISA ECONÔMICA APLICADA. Diagnóstico sobre os Juizados Especiais Cíveis. Brasília: 2013.

JUNQUEIRA, Eliane. “Acesso à justiça: um olhar retrospectivo”. Revista Estudos Históricos, Rio de Janeiro, n. 18, p. 389-401, 1996.

KAMP, Allan R. "The History Behind Hansberry v. Lee”. 20 U.C. Davis L. Rev. 481, 19861987, p. 481-499.

KOERNER, Andrei. “O debate sobre a reforma judiciária”. Novos Estudos. N. 54. jul.1999. São Paulo: CEBRAP, 1990, p. 11-26.

KOMESAR, Neil. Imperfect Alternatives: choosing institutions in law, economics, and public policy. Chicago: University of Chicago Press, 1994.

KRISLOV, Samuel. "The amicus curiae brief: from friendship to advocacy". The Yale Law Journal, v. 72, n. 4, p. 694-721, 1963.

KRITZER, Humbert M.; SILBEY, Susan (Eds.). In litigation: do the "haves" still come out ahead? Stanford: Stanford University Press, 2004.

LANGENEGGER. Natalia. Legitimidade ativa de pessoas físicas em ações coletivas:

incentivos e desincentivos institucionais. Dissertação de mestrado defendida na Escola de Direito da Fundação Getulio Vargas. São Paulo: 2014.

LARSEN, Allison Orr. "The Trouble with Amicus Facts". Virginia Law Review, p. 1757$1818,2014$. 
LIND, Edgar Allan; TYKER, Tom R. The Social Psychology of Procedural Justice. Nova York: Prelum Press, 1988.

LOPES, José Reinaldo de Lima. "Justiça e Poder Judiciário ou a virtude confronta a instituição” In Direitos Sociais: teoria e prática. São Paulo: Método, 2006, p. 119-139.

MANCUSO, Rodolfo de Camargo. Jurisdição coletiva e coisa julgada: teoria das ações coletivas. $3^{\text {a }}$ Ed. São Paulo: RT, 2012

MARINONI, Luis Guilherme. Incidente de Resolução de Demandas Repetitivas. São Paulo: RT, 2016a.

Precedentes Obrigatórios. $4^{\mathrm{a}}$ Edição. São Paulo: Revista dos Tribunais, $2016 \mathrm{~b}$.

. "Coisa julgada sobre questão, inclusive em benefício de terceiro". Revista de Processo. Vol. 256, set/2016c, p. 97-116, versão digital.

- "Comentários ao artigo 928" In WAMBIER, Teresa Arruda Alvim et.al (coord.). Breves comentários ao novo Código de Processo Civil. São Paulo: RT, 2015.

, "Elaboração dos conceitos de ratio decidendi (fundamentos determinantes da decisão) e obiter dictum no direito brasileiro". Instituto de Processo Comparado - Núcleo de Direito Processual Comparado. Set-2012. Disponível em http://institutodeprocesso.com.br/marinoni-elaboracao-dos-conceitos-de-ratio-decidendifundamentos-determinantes-da-decisao-e-obiter-dictum-no-direito-brasileiro/, acesso em 28 mar. 2015.

. Teoria Geral do Processo. $3^{\text {a }}$ Ed. São Paulo: RT, 2009.

MATTEI, Ugo. “Access to Justice. A Renewed Global Issue”. Electronic Journal of Comparative Law, Vol. 11.3, 2007. Disponível em: http://works.bepress.com/ugo mattei/34, acesso em 25 mar. 2016.

MEDINA, José Miguel Garcia; FREIRE, Alexandre; FREIRE, Alonso. "Audiência pública tornou-se instrumento de legitimidade". Conjur. Edição de 4 jul. 2013. Disponível em $<$ https://www.conjur.com.br/2013-jul-04/audiencias-publicas-tornaram-stf-instrumentolegitimidade-popular>, acesso em $11 \mathrm{dez} .2017$.

MEIRELES, Edilton. "Do incidente de resolução de demandas repetitivas no processo civil brasileiro" In DIDIER JR., Fredie; CUNHA, Leonardo Carneiro da. Julgamento de casos Repetitivos. Coleção Grandes Temas do Novo CPC. Vol. 10. Salvador: JusPodium, 2017, p. 65-138.

MELLO, Patrícia Perrone Campos. BARROSO, Luís Roberto. "Trabalhando com uma nova lógica: a ascensão dos precedentes no direito brasileiro". Revista da AGU, Brasília, v. 15, n. 03, p. 09-52, jul./set. 2016. 
MENDES, Aluisio Gonçalves de Castro. Incidente de Resolução de Demandas Repetitivas: sistematização, análise e interpretação do novo instituto processual. Rio de Janeiro: Forense, 2017.

. "O incidente de resolução de demandas repetitivas no novo Código de Processo Civil”. Revista de Processo. V. 243, maio/2015.

; SILVA, Larissa Clare da. "A legitimidade ativa do indivíduo nas ações coletivas" In GRINOVER, Ada Pellegrini (org.) et al. Processo coletivo: do surgimento à atualidade. São Paulo: Revista dos Tribunais, 2014, p. 1243-1254.

; RODRIGUES, Roberto de Aragão Ribeiro. "Reflexões sobre o incidente de resolução de demandas repetitivas previsto no projeto de novo Código de Processo Civil". Revista de Processo. Vol. 211. Set/2012, versão digital.

MENDES, Gilmar. "Novos aspectos do controle de constitucionalidade brasileiro". Direito Público, v. 6, n. 27, 2009.

. "A Reforma do Sistema Judiciário no Brasil: elemento fundamental para garantir segurança jurídica ao investimento estrangeiro no País". Palestra proferida na conferência promovida pela Organização para a Cooperação e o Desenvolvimento Econômico (OCDE), em Paris, França. Disponível em http://www.stf.jus.br/repositorio/cms/portalStfInternacional/portalStfAgenda pt br/anexo/dis cParisport1.pdf, acesso em 20 dez. 2017.

MINISTÉRIO DA FAZENDA. Secretaria de Política Econômica. Reformas microeconômicas e crescimento de longo prazo. Brasília, 2004.

MINISTÉRIO DA JUSTIÇA. Estratégia nacional de não judicialização: $1^{\circ}$ Relatório 20142015. Brasília: Secretaria e Reforma do Judiciário, 2016.

. Judiciário e Economia. Secretaria da Reforma do Judiciário, 2005.

. Tutela Judicial dos Interesses Metaindividuais Ações Coletivas. Brasília, 2007a.

MOURA, Marcos. "MPF impugna homologação de acordo entre Samarco, União, MG e ES". Valor $\quad$ Econômico. 302016.2 mai. 20 Disponível http://www.valor.com.br/empresas/4581229/mpf-impugna-homologacao-de-acordo-entresamarco-uniao-mg-e-es, acesso em 30 out. 2017.

MOREIRA, Diogo Rais Rodrigues. Audiência Pública no Supremo Tribunal Federal. Dissertação de Mestrado em Direito. Pontifícia Universidade Católica de São Paulo. São Paulo: 2012.

MOREIRA, José Carlos Barbosa. "Súmula, jurisprudência, precedente: uma escalada e seus riscos". Revista Dialética de Direito Processual. V. 27, 2005, n. 4, p. 49-58.

NUNES, Dierle. "Padronizar decisões sem empobrecer o discurso jurídico?". Consultor Jurídico. Edição de 06 ago. 06. Disponível em http://www.conjur.com.br/, acesso em 28 mar. 2015. 
OLIVEIRA, Carlos Alberto Álvaro de. "A Garantia do Contraditório". Revista da Faculdade de Direito da UFRGS. N. 15. Porto Alegre: UFRGS, 1998, p. 7-20. Disponível em < http://www.seer.ufrgs.br/index.php/revfacdir/art MOREIRA, José Carlos Barbosa. "Súmula, jurisprudência, precedente: uma escalada e seus riscos". Revista Dialética de Direito Processual. V. 27, 2005, n. 4, p. 49-58.

icle/view/70385/39893>, acesso em 12 out. 2017.

"O processo civil na perspectiva os direitos fundamentais". Revista da Faculdade de Direito da UFRGS. N. 22. Porto Alegre: UFRGS, 2002, p. 31-42. Disponível em <http://seer.ufrgs.br/index.php/revfacdir/article/view/72635/41107>, acesso em 9 out. 2017, p. 39-42.

OLIVEIRA JR., Paulo Silvestre de. "Inteligência artificial é uma realidade e já afeta a área jurídica". Conjur. 15 set. 2017. Disponível em <http://www.conjur.com.br/2017-set-15/chiesifilho-inteligencia-artificial-afeta-area-juridica>, acesso em 25 set. 2017.

PINHEIRO, Armando Castellar (org.). Judiciário e Economia no Brasil. Rio de Janeiro: Centro Edelstein de Pesquisas Sociais, 2009.

PORTO, Júlia Pinto Ferreira. Acesso à justiça: Projeto Florença e Banco Mundial. Dissertação. Mestrado em Direito Político e Econômico: Universidade Presbiteriana Mackenzie, São Paulo, 2009.

RESNIK, Judith. "The Story of Goldberg: why this case is our shorthand". CLERMONT, Kevin M. (ed.). Civil Procedure Stories. $2^{\mathrm{a}}$ Ed. Nova York: Thomson/Foundation Press, 2008, p. 473-508.

RHODE, Deborah L. Access to justice. New York: Oxford University Press, 2004

RODRIGUES, Marcelo Abelha. "Técnicas individuais de repercussão coletiva $\mathrm{x}$ técnicas coletivas de repercussão individual. Por que estão extinguindo a ação civil pública para a defesa de direitos individuais homogêneos?" In MILARÉ, Édis (Coord.). Ação civil pública após 30 anos. São Paulo: Revista dos Tribunais, 2015, p. 555-567.

ROQUE, André Vasconcelos. "Ações coletivas e procedimentos para a resolução de casos repetitivos" In DIDIER JR., Fredie; CUNHA, Leonardo Carneiro da. Julgamento de casos Repetitivos. Coleção Grandes Temas do Novo CPC. Vol. 10. Salvador: JusPodium, 2017, p. $15-36$.

. "O que significa representatividade adequada? Um estudo de direito comparado". Revista Eletrônica de Direito Processual. Vol. IV. N. 4, 2009, p. 171-198.

SADEK, Maria Tereza. “Acesso à justiça: um direito e seus obstáculos”. Revista USP. n. 101, março/abril/maio 2014, p. 55-66.

. "Judiciário e arena pública: um olhar a partir da ciência política" In GRINOVER, Ada P.; WATANABE, Kazuo (coord). O Controle Jurisdicional de Políticas Públicas. São Paulo: GEN, 2013, p. 1-32. 
79-101, 2004.

. Judiciário: mudanças e reformas. Estudos Avançados, São Paulo, v. 18, n. 51, p.

. "O Sistema de Justiça”. O Sistema de Justiça. SADEK, Maria Tereza (Org.). Rio de Janeiro: Centro Edelstein de Pesquisas Sociais, 2010, p. 1-23.

SALINAS, Natasha Schmitt Caccia. "Caso Samarco: implicações jurídicas, econômicas e sociais do maior desastre ambiental do Brasil" In FALCÃO, Joaquim; PORTO, Antonio José Maristrello; ALCÂNTARA, Paulo Augusto Franco de. Depois da lama: Mariana e as consequencias de um desastre ambiental construido. Belo Horizonte: Letramento, 2016, p. 197-233.

SALLES, Carlos Alberto de. "Precedentes e jurisprudência no Novo CPC: Novas técnicas decisórias". In GRINOVER, Ada Pellegrini [et al.]. O Novo Código de Processo Civil Questões controvertidas. São Paulo: Atlas, 2015, p. 77-88.

. Arbitragem em Contratos Administrativos. Rio de Janeiro: Forense, 2011.

- Mecanismos alternativos de solução de controvérsias e acesso à justiça: a inafastabilidade da tutela jurisdicional recolocadas. In: FUX, Luiz; NERY JR., Nelson; WAMBIER, Teresa Arruda Alvim. Processo e Constituição. Estudos em homenagem ao Professor José Carlos Barbosa Moreira. São Paulo: Revista dos Tribunais, 2006a. p.779-785

. "Ações coletivas: premissas para comparação com o sistema jurídico norteamericano". In: SALLES, Carlos Alberto de; SILVA, Solange Teles da; NUSDEO, Ana Maria de Oliveira. (Org.). Processos Coletivos e Tutela Ambiental. Santos: EDUL - Editora Universitária Leopoldianum, 2006b, v. , p. 17-33.

. "Entre a eficiência e a equidade: bases conceituais para um direito processual coletivo". Revista de Direitos Difusos. Vol. 36. Direito Processual Coletivo I, mar./abr. 2006, p. 13-31.

SANDEFUR, Rebecca L. "Access to Civil Justice and Race, Class, and Gender Inequality". Annual Review of Sociology, Vol. 34, August 2008, p. 339-358.

SANTOS, Boaventura de Sousa. Pela mão de Alice: o social e o político na pósmodernidade. Porto: Afrontamento, 1994.

. O Direito dos Oprimidos. São Paulo: Cortez, 2014.

. Para uma revolução democrática da justiça. Coimbra: Almedina, 2015.

SICA, Heitor Vitor Mendonça. "Brevíssimas reflexões sobre a evolução do tratamento da litigiosidade repetitiva no ordenamento brasileiro, do CPC/1973 ao CPC/2015". Revista de Processo. RT: São Paulo, v. 41, n. 257, jul. 2016, p. 269-281.

Atlas.

. Preclusão processual civil. Col. Atlas de Processo Civil. 2a Edição. São Paulo: 
SILVA, Paulo Eduardo Alves da. Gerenciamento de processos judiciais. São Paulo: Saraiva, 2010 .

SILVA, Dicken William; "Litígio Estratégico de Interesse Público e Ministério Público: Reflexões sobre a Natureza Instrumental da Independência Funcional" In Revista do Ministério Público do Distrito Federal e Territórios. N. 7. Brasília: MPF, 2013, p. 73-108, 2013.

SOARES, Ricardo. "Navio da Petrobras derrama nafta no Paraná". Folha de São Paulo. 19 out. 2001. Caderno Cotidiano. Disponível em $<$ http://www1.folha.uol.com.br/fsp/cotidian/ff1910200111.htm>, acesso em 16 dez. 2017.

SOMBRA, Thiago Luís Santos. "Supremo Tribunal Federal representativo? O impacto das audiências públicas na deliberação". Revista Direito GV. V. 31, n. 1, jan.-abril 2017, FGV: São Paulo, p. 236-273.

TALAMINI, Eduardo. "A dimensão coletiva dos direitos individuais homogêneos" In DIDIER JR., Fredie (coord.). Julgamento de Casos Repetitivos. Col. Grandes Temas do Novo CPC. Salvador: Juspodium, 2017, p. 139-166.

TEMER, Sofia. Incidente de Resolução de Demandas Repetitivas. $2^{\mathrm{a}}$ Ed. Salvador: Juspodium, 2017.

THEODORO JR., Humberto. Curso de Direito Processual Civil, Vol. I. 56 a Ed. Rio de Janeiro: Forense, 2015.

; NUNES, Dierle; BAHIA, Alexandre. "Breves considerações sobre a politização do Judiciário e sobre o panorama de aplicação no direito brasileiro - Análise da convergência entre o civil law e o common law e dos problemas da padronização decisória". Revista de Processo. v. 35, n. 189, São Paulo: RT, 2010, p. 9-52.

TUCCI, José Roberto Cruz e. Precedente judicial como fonte do direito. São Paulo: RT, 2004.

VIEIRA, Douglas. "BOT: conheça o robô-advogado que atende clientes em português". Tecmundo. 14 set. 2017. Disponível em < https://www.tecmundo.com.br/software/122052bot-conheca-robo-advogado-atende-clientes-portugues.htm>, acesso em 25 set. 2017.

WAMBIER, Teresa Arruda Alvim. "Distinção entre questão de fato e questão de direito para fins de cabimento de recurso especial". Revista de Processo. v. 23, n. 92, out./dez., 1998, p. $52-70$.

WATANABE, Kazuo. "Filosofia e características básicas do Juizado Especial de Pequenas Causas" In WATANABE, Kazuo (Org.). Juizado Especial de Pequenas Causas (Lei 7.244, de 7 de novembro de 1984). São Paulo: RT, 1985.

- "Acesso à Justiça e Sociedade Moderna" In GRINOVER, Ada Pellegrini; DINAMARCO, Cândido Rangel; WATANABE, Kazuo, (coords.). Participação e Processo. São Paulo: Revista dos Tribunais, 1988. 
WORLD BANK. “About Doing Business". Doing Business 2016. World Bank: 2016. Disponível em http://www.doingbusiness.org/reports/globalreports/ /media/GIAWB/Doing\%20Business/Documents/Annual-Reports/English/DB16Chapters/DB16-About-Doing-Business.pdf, acesso em 7 de jul. 2016.

ZUFELATO, Camilo. “O princípio do contraditório no Projeto de Novo CPC”. Jornal Carta Forense. 3 out. 2013. Disponível em <http://www.cartaforense.com.br/conteudo/artigos/oprincipio-do-contraditorio-no-projeto-de-novo-cpc/12140> acesso em 12 out. 2017. 


\section{ANEXO}

\section{Relação dos temas julgados pelo STJ analisados no estudo empírico-jurisprudencial}

\begin{tabular}{|c|c|c|c|c|}
\hline tema & questao_submetida_a_julgamento & tese_firmada & processo & julgado_em \\
\hline 1 & $\begin{array}{l}\text { Questão referente à necessidade de } \\
\text { anuência do devedor para substituição } \\
\text { processual do polo ativo, decorrente } \\
\text { de cessão de crédito, nos autos de ação } \\
\text { de execução. }\end{array}$ & $\begin{array}{l}\text { A substituição processual, no polo } \\
\text { ativo da execução, do exequente } \\
\text { originário pelo cessionário dispensa a } \\
\text { autorização ou o consentimento do } \\
\text { devedor. }\end{array}$ & REsp 1091443/SP & $02 / 05 / 2012$ \\
\hline 2 & $\begin{array}{l}\text { Questão referente à possibilidade de } \\
\text { habilitação de cessionário de crédito } \\
\text { referente a honorários advocatícios } \\
\text { sucumbenciais que integra precatório } \\
\text { expedido em nome do exeqüente e não } \\
\text { dos advogados cedentes. }\end{array}$ & $\begin{array}{l}\text { Comprovada a validade do ato de } \\
\text { cessão dos honorários advocatícios } \\
\text { sucumbenciais, realizado por escritura } \\
\text { pública, bem como discriminado no } \\
\text { precatório o valor devido a título da } \\
\text { respectiva verba advocatícia, deve-se } \\
\text { reconhecer a legitimidade do } \\
\text { cessionário para se habilitar no crédito } \\
\text { consignado no precatório. }\end{array}$ & REsp 1102473/RS & $16 / 05 / 2012$ \\
\hline 3 & $\begin{array}{l}\text { Questão referente à conversão dos } \\
\text { vencimentos em URV de servidores } \\
\text { do Poder Executivo gaúcho, conforme } \\
\text { a Lei } 8.880 / 94, \text { deixando-se de } \\
\text { considerar os reajustes/antecipações } \\
\text { que foram objeto de várias leis } \\
\text { estaduaus do Rio Grande do Sul. }\end{array}$ & $\begin{array}{l}\text { A imposição ao Estado do Rio Grande } \\
\text { do Sul da conversão das retribuições } \\
\text { aos servidores pela URV (Lei } \\
\text { 8.880/94), apesar dos reajustes } \\
\text { voluntários já concedidos à categoria } \\
\text { pelo Governo Gaúcho a pretexto } \\
\text { dessa mesma conversão, somente } \\
\text { seria cabível se evidenciado algum } \\
\text { prejuízo vencimental decorrente } \\
\text { daquela antecipação voluntária. }\end{array}$ & REsp 970217/RS & $14 / 10 / 2009$ \\
\hline 4 & $\begin{array}{l}\text { Questão referente ao percentual de } \\
\text { juros moratórios devido nas } \\
\text { condenações impostas à Fazenda } \\
\text { Pública para pagamento de verbas } \\
\text { remuneratórias a servidores públicos, } \\
\text { nos termos do artigo } 1^{\circ} \text {-F da Lei no } \\
\text { 9.494/97, acrescentado pela Medida } \\
\text { Provisória } \mathrm{n}^{\circ} 2.180 / 2001 \text {. }\end{array}$ & $\begin{array}{l}\text { O art. } 1^{\circ}-\mathrm{F} \text {, da Lei } 9.494 / 97 \text {, que fixa } \\
\text { os juros moratórios nas ações } \\
\text { ajuizadas contra a Fazenda Pública no } \\
\text { patamar de } 6 \% \text {, é de ser aplicado tão } \\
\text { somente às demandas ajuizadas após a } \\
\text { sua entrada em vigor. }\end{array}$ & REsp 1086944/SP & $11 / 03 / 2009$ \\
\hline 5 & $\begin{array}{l}\text { Questão referente à prescrição da } \\
\text { pretensão de militares inativos da } \\
\text { Polícia Militar do Estado do Rio } \\
\text { Grande do Sul ao reconhecimento dos } \\
\text { benefícios concedidos pela Lei } \\
\text { Complementar Estadual n }{ }^{\circ} \text { 10.990/97. }\end{array}$ & $\begin{array}{l}\text { Na hipótese em que se pretende a } \\
\text { revisão de ato de reforma de policial } \\
\text { militar do Estado do Rio Grande do } \\
\text { Sul, com base na Lei Complementar } \\
\text { Estadual no } 10.990 / 97, \text { com sua } \\
\text { promoção a um posto superior na } \\
\text { carreira militar e, como mera } \\
\text { consequência do deferimento do } \\
\text { pedido de promoção, a revisão de seus } \\
\text { proventos da inatividade, a prescrição } \\
\text { aplicável é de fundo do direito, nos } \\
\text { termos do artigo } 1^{\circ} \text { do Decreto } n^{\circ} \\
20.910 / 32 \text {. }\end{array}$ & REsp 1073976/RS & $26 / 11 / 2008$ \\
\hline 6 & $\begin{array}{l}\text { Questão relativa ao reajuste de } \\
28,86 \% \text {, decorrente das Leis } \mathrm{n}^{\circ} \mathrm{s} \\
8.622 / 93 \text { e } 8.627 / 93 \text {, no que pertine à } \\
\text { concessão do referido índice aos } \\
\text { militares federais. }\end{array}$ & $\begin{array}{l}\text { Os servidores públicos militares, que } \\
\text { foram contemplados com reajustes } \\
\text { inferiores (concedidos pelas Leis } \\
8.622 / 1993 \text { e } 8.627 / 1993 \text { ), têm direito } \\
\text { às diferenças entre estes e o índice de } \\
28,86 \% \text {. }\end{array}$ & REsp 990284/RS & $26 / 11 / 2008$ \\
\hline 7 & $\begin{array}{l}\text { Questão relativa ao reajuste de } \\
28,86 \% \text {, decorrente das Leis } \mathrm{n}^{\circ} \mathrm{s} \\
8.622 / 93 \text { e } 8.627 / 93, \text { no que pertine à } \\
\text { base de cálculo do reajuste. }\end{array}$ & $\begin{array}{l}\text { O reajuste de } 28,86 \% \text { incide sobre a } \\
\text { remuneração do servidor, o que inclui } \\
\text { o vencimento básico (servidor público } \\
\text { civil) ou o soldo (militar), acrescido } \\
\text { das parcelas que não os têm como } \\
\text { base de cálculo. }\end{array}$ & REsp 990284/RS & $26 / 11 / 2008$ \\
\hline
\end{tabular}


8 Questão relativa ao reajuste de $28,86 \%$, decorrente das Leis $n^{\circ} \mathrm{s}$ $8.622 / 93$ e $8.627 / 93$, no que pertine ao termo inicial da correção monetária.

9 Questão relativa ao reajuste de $28,86 \%$, decorrente das Leis $n^{\circ} \mathrm{s}$ $8.622 / 93$ e $8.627 / 93$, no que pertine à compensação com a complementação do salário mínimo, pela aplicação do artigo 73 da Lei $\mathrm{n}^{\circ} 8.237 / 91$.

10 Questão relativa ao reajuste de $28,86 \%$, decorrente das Leis $\mathrm{n}^{\circ} \mathrm{s}$ $8.622 / 93$ e $8.627 / 93$, no que pertine à contagem do prazo prescricional.

11 Questão relativa ao reajuste de $28,86 \%$, decorrente das Leis $n^{\circ} \mathrm{s}$ $8.622 / 93$ e $8.627 / 93$, no que pertine à contagem do prazo prescricional.

12 Questão relativa ao reajuste de $28,86 \%$, decorrente das Leis $\mathrm{n}^{\circ} \mathrm{s}$ $8.622 / 93$ e $8.627 / 93$, no que pertine à contagem do prazo prescricional.

13 Questão relativa ao reajuste de $28,86 \%$, decorrente das Leis $n^{\circ} \mathrm{s}$ $8.622 / 93$ e $8.627 / 93$, no que pertine à limitação temporal do percentual de $28,86 \%$ ao advento da primeira edição da Medida Provisória ${ }^{\circ}$ 2.131/2000.

14 Questão referente ao pagamento de diferenças de vencimentos a professores do Estado do Amapá por força de desvio de função.

15 Questão referente à admissibilidade da conversão dos valores de vencimentos/proventos de servidor público municipal, recebidos em cruzeiros reais, para o equivalente em URV, nos termos da Lei Federal $\mathrm{n}^{\circ}$ 8.880/94.

16 Questiona-se a imposição de pena de deserção (não-conhecimento de recurso do INSS, na Justiça Estadual, por ausência de preparo).

17 Questiona-se o não conhecimento de reexame necessário (valor da causa tido como parâmetro para aplicação do art. $475, \S 2^{\circ}$, do CPC).

18 Questão referente à possibilidade de aplicação da majoração do percentual do auxílio-acidente, estabelecida pela Lei . $^{\circ}$ 9.032/95, independentemente da legislação em vigor à época de sua concessão.
A correção monetária deve incidir a partir da data em que deveria ter sido efetuado o pagamento de cada parcela.

O reajuste de $28,86 \%$ não pode ser compensado com a rubrica paga a título de complementação de salário mínimo.

Quanto a prescrição à pretensão dos servidores públicos militares ao reajuste de $28,86 \%$ : i) se ajuizada a ação ordinária dos servidores até 30/06/2003, os efeitos financeiros devem retroagir a janeiro de 1993

\begin{tabular}{|l|l|l}
\hline Quanto a prescrição à pretensão dos & REsp 990284/RS & 26/11/2008
\end{tabular}
servidores públicos militares ao reajuste de $28,86 \%$ : ii) se proposta após 30/06/2003, deve ser aplicado apenas o enunciado da Súmula 85 desta Corte.

Quanto a prescrição à pretensão dos servidores públicos militares ao reajuste de $28,86 \%$ : iii) se ajuizada a ação pelo militar após 1\%01/2006, ocorre a prescrição de todas as parcelas devidas ao militar a título de reajuste de $28,86 \%$.

A concessão do reajuste de $28,86 \%$

deve se limitar ao advento da Medida Provisória n. 2.131, de 28/12/2000, que reestruturou a remuneração dos militares das Forças Armadas, com a absorção das diferenças de reajustes eventualmente existentes.

Reconhecido o desvio de função, o servidor faz jus às diferenças salariais decorrentes.

É obrigatória a observância pelos

Estados e Municípios dos critérios previstos na Lei Federal no 8.880/94 para a conversão em URV dos vencimentos e dos proventos de seus servidores.

O INSS não está obrigado a efetuar depósito prévio do preparo por gozar das prerrogativas e privilégios da Fazenda Pública.

A dispensa de reexame necessário, quando o valor da condenação ou do direito controvertido for inferior a sessenta salários mínimos, não se aplica a sentenças ilíquidas.

A majoração do auxílio-acidente, estabelecida pela Lei 9.032/95 (lei nova mais benéfica), que alterou o $\S$ $1^{\circ}$, do art. 86, da Lei n. ${ }^{\circ} 8.213 / 91$, deve ser aplicada imediatamente, atingindo todos os segurados que estiverem na mesma situação, seja referente aos casos pendentes de concessão ou aos benefícios já concedidos.

\begin{tabular}{|l|l|} 
REsp 990284/RS & $26 / 11 / 2008$ \\
\hline REsp 990284/RS & $26 / 11 / 2008$ \\
& \\
\hline
\end{tabular}

REsp 990284/RS 26/11/2008


19 Questiona-se a utilização do IGP-DI como critério de correção monetária incidente entre a data da elaboração dos cálculos e a inscrição do precatório. Alega-se que, sobre os valores encontrados naquela data, não mais incidem os índices de correção monetária previdenciários, mas, sim, a UFIR ou o IPCA-e.

20 Questiona-se se a prestação de serviços à comunidade pode ser fixada pena em regime aberto.

21 Questiona-se a imprescindibilidade do requisito "condição de segurado do de cujus" para os dependentes fazerem jus ao benefício de pensão por morte, situação somente excetuada no caso daquele ter preenchido em vida os requisitos necessários ao deferimento de qualquer uma das aposentadorias previstas no Regime Geral de Previdência Social - RGPS.

22 Questão referente à decisão que, observando, única e exclusivamente, a perda mínima auditiva (inferior a índice previsto na tabela de Fowler), nega a concessão do benefício de auxílio-acidente.

23 Questiona-se se as certidões expedidas pela Administração não têm o condão de interromper a prescrição. como condição para o cumprimento da

Os débitos previdenciários remanescentes pagos mediante precatório, devem ser convertidos, à data do cálculo, em quantidade de Unidade Fiscal de Referência - UFIR ou em outra unidade de referência oficial que venha a substituí-la.

É inadmissível a fixação de pena substitutiva (art. 44 do $\mathrm{CP}$ ) como condição especial ao regime aberto.

É devida a pensão por morte aos dependentes do segurado que, apesar de ter perdido essa qualidade, preencheu os requisitos legais para a obtenção de aposentadoria até a data do seu óbito.

Comprovados o nexo de causalidade e a redução da capacidade laborativa, mesmo em face da discusão em grau inferior ao estabelecido pela Tabela Fowler, subsiste o direito do obreiro ao benefício de auxílio-acidente.

Importa em interrupção da prescrição a confissão realizada por meio de certidão individual emitida pelo Tribunal de Justiça (...), acerca da existência de dívida de valor consolidado em favor de servidor público integrante de seu respectivo Quadro.

24 Discussão acerca dos juros remuneratórios em ações que digam respeito a contratos bancários.

25 Discussão acerca dos juros remuneratórios em ações que digam respeito a contratos bancários.

26 Discussão acerca dos juros remuneratórios em ações que digam respeito a contratos bancários.

27 Discussão acerca dos juros remuneratórios em ações que digam respeito a contratos bancários. remuneratórios estipulada na Lei de 596/STF.
28 Discussão acerca dos juros remuneratórios, da capitalização de juros e da mora em ações que digam respeito a contratos bancários.

29 Discussão acerca da mora em ações que digam respeito a contratos bancários.
As instituições financeiras não se sujeitam à limitação dos juros Usura (Decreto 22.626/33), Súmula

A estipulação de juros remuneratórios superiores a $12 \%$ ao ano, por si só, não indica abusividade.

\section{São inaplicáveis aos juros}

remuneratórios dos contratos de mútuo bancário as disposições do art. $591 \mathrm{c} / \mathrm{c}$ o art. 406 do CC/02.

É admitida a revisão das taxas de juros remuneratórios em situações excepcionais, desde que caracterizada a relação de consumo e que a abusividade (capaz de colocar o consumidor em desvantagem exagerada (art. 51, $\$ 1^{\circ}$, do CDC) fique cabalmente demonstrada, ante às peculiaridades do julgamento em concreto.

O reconhecimento da abusividade nos encargos exigidos no período da normalidade contratual (juros remuneratórios e capitalização) descaracteriza a mora.

A simples propositura da ação de revisão de contrato não inibe a caracterização da mora do autor.

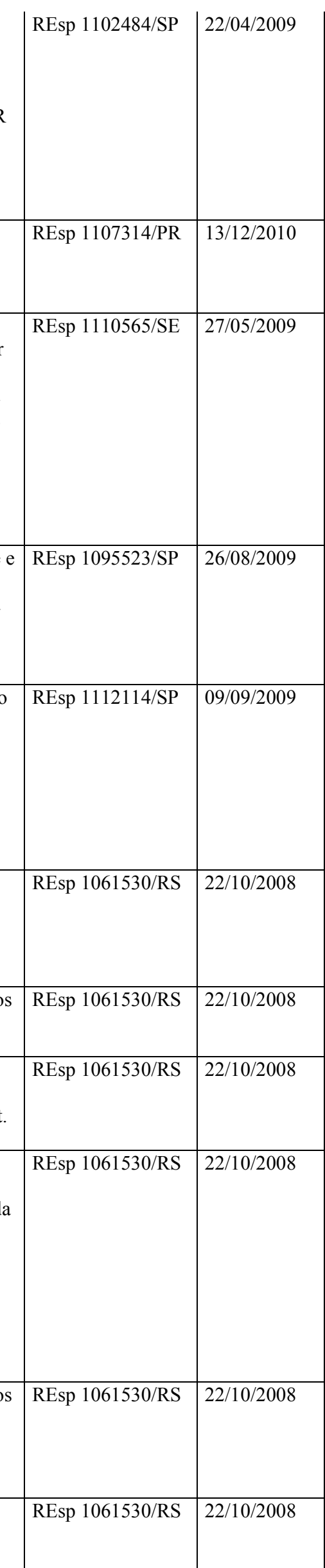


30 Discute matérias, quando ativadas em ações que digam respeito a contratos bancários: a) juros remuneratórios; b) capitalização de juros; c)mora; d) comissão de permanência; e) inscrição do nome do devedor em cadastros de proteção ao crédito; f) disposições de ofício no âmbito do julgamento da apelação acerca de questões não devolvidas ao tribunal.

31 Discussão acerca da mora e da inscrição do nome do devedor em cadastros de proteção ao crédito em ações que digam respeito a contratos bancário.

32 Discussão acerca da mora e da inscrição do nome do devedor em cadastros de proteção ao crédito em ações que digam respeito a contratos bancários.
Nos contratos bancários, não-regidos por legislação específica, os juros moratórios poderão ser convencionados até o limite de $1 \%$ ao mês.

A abstenção da inscrição/manutenção em cadastro de inadimplentes, requerida em antecipação de tutela e/ou medida cautelar, somente será deferida se, cumulativamente: i) a ação for fundada em questionamento integral ou parcial do débito;ii) houver demonstração de que a cobrança indevida se funda na aparência do bom direito e em jurisprudência consolidada do STF ou STJ;iii) houver depósito da parcela incontroversa ou for prestada a caução fixada conforme o prudente arbítrio do juiz. A inscrição/manutenção do nome do devedor em cadastro de inadimplentes decidida na sentença ou no acórdão observará o que for decidido no mérito do processo. Caracterizada a mora, correta a inscrição/manutenção.

A abstenção da inscrição/manutenção em cadastro de inadimplentes, requerida em antecipação de tutela e/ou medida cautelar, somente será deferida se, cumulativamente: i) a ação for fundada em questionamento integral ou parcial do débito; ii) houver demonstração de que a cobrança indevida se funda na aparência do bom direito e em jurisprudência consolidada do STF ou STJ; iii) houver depósito da parcela incontroversa ou for prestada a caução fixada conforme o prudente arbítrio do juiz. A inscrição/manutenção do nome do devedor em cadastro de inadimplentes decidida na sentença ou no acórdão observará o que for decidido no mérito do processo. Caracterizada a mora, correta a inscrição/manutenção.

33 Discussão acerca da inscrição do nome do devedor em cadastros de proteção ao crédito em ações que digam respeito a contratos bancários.
A abstenção da inscrição/manutenção em cadastro de inadimplentes, requerida em antecipação de tutela e/ou medida cautelar, somente será deferida se, cumulativamente: i) a ação for fundada em questionamento integral ou parcial do débito; ii) houver demonstração de que a cobrança indevida se funda na aparência do bom direito e em jurisprudência consolidada do STF ou STJ; iii) houver depósito da parcela incontroversa ou for prestada a caução fixada conforme o prudente arbítrio do juiz. A inscrição/manutenção do

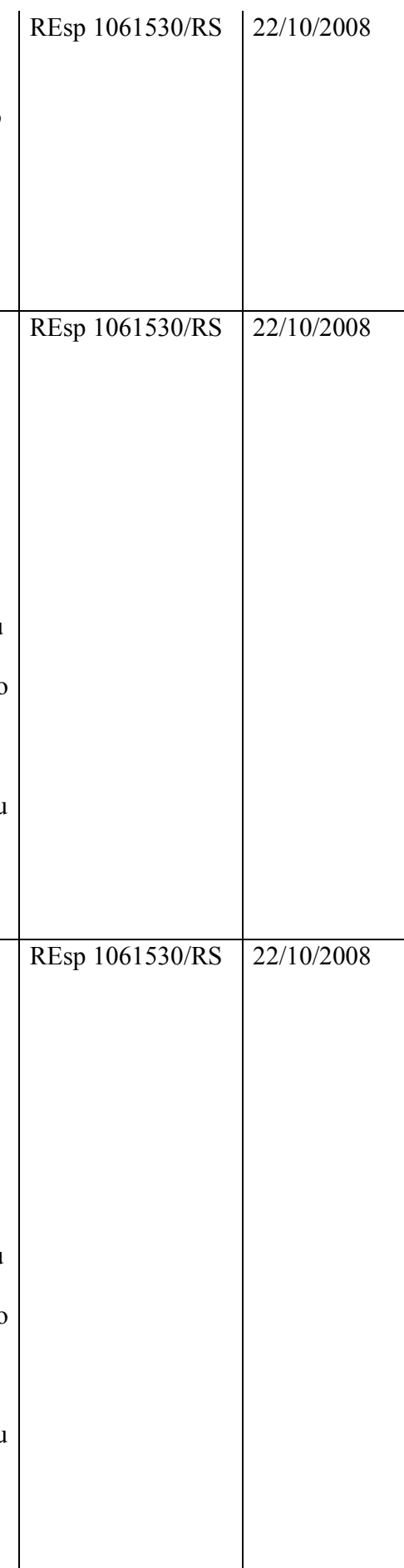

\begin{tabular}{|l|l|} 
REsp 1061530/RS & 22/10/2008 \\
& \\
&
\end{tabular}




\begin{tabular}{|c|c|c|c|c|}
\hline & & $\begin{array}{l}\text { nome do devedor em cadastro de } \\
\text { inadimplentes decidida na sentença ou } \\
\text { no acórdão observará o que for } \\
\text { decidido no mérito do processo. } \\
\text { Caracterizada a mora, correta a } \\
\text { inscrição/manutenção. }\end{array}$ & & \\
\hline 34 & $\begin{array}{l}\text { Discussão acerca da inscrição do nome } \\
\text { do devedor em cadastros de proteção } \\
\text { ao crédito em ações que digam } \\
\text { respeito a contratos bancários. }\end{array}$ & $\begin{array}{l}\text { A abstenção da inscrição/manutenção } \\
\text { em cadastro de inadimplentes, } \\
\text { requerida em antecipação de tutela } \\
\text { e/ou medida cautelar, somente será } \\
\text { deferida se, cumulativamente: i) a } \\
\text { ação for fundada em questionamento } \\
\text { integral ou parcial do débito; ii) } \\
\text { houver demonstração de que a } \\
\text { cobrança indevida se funda na } \\
\text { aparência do bom direito e em } \\
\text { jurisprudência consolidada do STF ou } \\
\text { STJ; iii) houver depósito da parcela } \\
\text { incontroversa ou for prestada a caução } \\
\text { fixada conforme o prudente arbítrio } \\
\text { do juiz. A inscrição/manutenção do } \\
\text { nome do devedor em cadastro de } \\
\text { inadimplentes decidida na sentença ou } \\
\text { no acórdão observará o que for } \\
\text { decidido no mérito do processo. } \\
\text { Caracterizada a mora, correta a } \\
\text { inscrição/manutenção. }\end{array}$ & REsp 1061530/RS & $22 / 10 / 2008$ \\
\hline 35 & $\begin{array}{l}\text { Discussão acerca da mora e da } \\
\text { inscrição do nome do devedor em } \\
\text { cadastros de proteção ao crédito em } \\
\text { ações que digam respeito a contratos } \\
\text { bancários. }\end{array}$ & $\begin{array}{l}\text { A inscrição/manutenção do nome do } \\
\text { devedor em cadastro de inadimplentes } \\
\text { decidida na sentença ou no acórdão } \\
\text { observará o que for decidido no } \\
\text { mérito do processo. Caracterizada a } \\
\text { mora, correta a inscrição/manutenção. }\end{array}$ & REsp 1061530/RS & $22 / 10 / 2008$ \\
\hline 36 & $\begin{array}{l}\text { Discute matérias, quando ativadas em } \\
\text { ações que digam respeito a contratos } \\
\text { bancários: a) juros remuneratórios; b) } \\
\text { capitalização de juros; c)mora; d) } \\
\text { comissão de permanência; e) inscrição } \\
\text { do nome do devedor em cadastros de } \\
\text { proteção ao crédito; f) disposições de } \\
\text { ofício no âmbito do julgamento da } \\
\text { apelação acerca de questões não } \\
\text { devolvidas ao tribunal. }\end{array}$ & $\begin{array}{l}\text { Nos contratos bancários, é vedado ao } \\
\text { julgador conhecer, de ofício, da } \\
\text { abusividade das cláusulas. }\end{array}$ & REsp 1061530/RS & $22 / 10 / 2008$ \\
\hline 37 & $\begin{array}{l}\text { Discussão sobre indenização por } \\
\text { danos morais decorrente de inscrição } \\
\text { do nome do devedor nos cadastros de } \\
\text { restrição ao crédito com ausência de } \\
\text { comunicação prévia, em especial nos } \\
\text { casos onde o devedor já possua outras } \\
\text { inscrições nos cadastros de devedores. }\end{array}$ & $\begin{array}{l}\text { Os órgãos mantenedores de cadastros } \\
\text { possuem legitimidade passiva para as } \\
\text { ações que buscam a reparação dos } \\
\text { danos morais e materiais decorrentes } \\
\text { da inscrição, sem prévia notificação, } \\
\text { do nome de devedor em seus } \\
\text { cadastros restritivos, inclusive quando } \\
\text { os dados utilizados para a negativação } \\
\text { são oriundos do CCF do Banco } \\
\text { Central ou de outros cadastros } \\
\text { mantidos por entidade diversas. }\end{array}$ & REsp 1061134/RS & $10 / 12 / 2008$ \\
\hline
\end{tabular}


38 Discussão sobre indenização por danos morais decorrente de inscrição do nome do devedor nos cadastros de restrição ao crédito com ausência de comunicação prévia, em especial nos casos onde o devedor já possua outras inscrições nos cadastros de devedores.

39 Questão referente à reivindicação e posse das terras que o Espólio de Anastácio Pereira Braga e Outros alegam ser de sua propriedade e que hoje formam o Condomínio Porto Rico, em Santa Maria no Distrito Federal.

40 Discussão sobre indenização por danos morais decorrente de inscrição do nome do devedor nos cadastros de restrição ao crédito com ausência de comunicação prévia, em especial nos casos onde o devedor já possua outras inscrições nos cadastros de devedores.

41 Discute-se sobre indenização por danos morais decorrente de inscrição do nome do devedor nos cadastros de restrição ao crédito com ausência de comunicação prévia, em especial nos casos onde o devedor já possua outras inscrições nos cadastros de devedores.

42 Necessidade de prévio requerimento administrativo para a demonstração de interesse na cautelar de exibição de documentos, preparatória de demanda de complementação de ações.

43 comprovação do pagamento do custo do serviço como requisito de procedibilidade da ação de exibição de documentos em face da sociedade anônima.

44 Incidência de prescrição nos contratos de participação financeira.

45 Incidência da prescrição nos contratos de participação financeira.

46 Estabelecer o valor patrimonial da ação de adquirentes de linha telefônica.

47 Questão referente à aplicação do art. 359 do CPC nas ações cautelares de exibição de documentos.
Os órgãos mantenedores de cadastros possuem legitimidade passiva para as ações que buscam a reparação dos danos morais e materiais decorrentes da inscrição, sem prévia notificação, do nome de devedor em seus cadastros restritivos, inclusive quando os dados utilizados para a negativação são oriundos do CCF do Banco Central ou de outros cadastros mantidos por entidade diversas. A mera existência de ação tendo por objeto a declaração de nulidade de registro imobiliário não é suficiente para se concluir pela ilegitimidade ativa daquele que, com base nesse mesmo registro, ajuíza ação reivindicatória.

\begin{tabular}{|l|l|l} 
A ausência de prévia comunicação ao & REsp 1062336/RS & 10/12/2008
\end{tabular}
consumidor da inscrição do seu nome em cadastros de proteção ao crédito, prevista no art. $43, \S 2^{\circ}$, do CDC, enseja o direito à compensação por danos morais.

Da anotação irregular em cadastro de proteção ao crédito, não cabe indenização por dano moral, quando preexistente legítima inscrição, ressalvado o direito ao cancelamento.

Falta ao autor interesse de agir para a ação em que postula a obtenção de documentos com dados societários, se não logra demonstrar haver apresentado requerimento formal à ré nesse sentido.

\section{A comprovação do pagamento do} 'custo do serviço' referente ao fornecimento de certidão de assentamentos constantes dos livros da companhia é requisito de procedibilidade da ação de exibição de documentos ajuizada em face da sociedade anônima.

A prescrição incidente nas ações que visem à subscrição complementar de ações rege-se pelo prazo vintenário ou decenário, conforme as regras do anterior ou do atual Código Civil.

Quanto aos dividendos, além do que foi dito acima, só prescreveria o direito a partir do reconhecimento do direito à diferença das ações.

Nos contratos de participação financeira para a aquisição de linha telefônica, o Valor Patrimonial da Ação (VPA) é apurado com base no balancete do mês da integralização.

A presunção de veracidade contida no art. 359 do Código de Processo Civil não se aplica às ações cautelares de exibição de documentos.

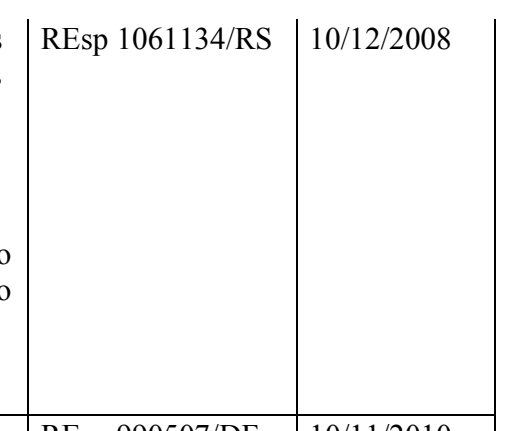

REsp 990507/DF $10 / 11 / 2010$

R

(n)

REsp 1062336/RS $10 / 12 / 2008$

REsp 982133/RS

$10 / 09 / 2008$

REsp 1033241/RS 22/10/2008

REsp 1033241/RS 22/10/2008

\begin{tabular}{|l|l|l|} 
& REsp 1033241/RS & $22 / 10 / 2008$ \\
\hline no & REsp 1094846/MS & $11 / 03 / 2009$ \\
\hline & & \\
\hline
\end{tabular}




\begin{tabular}{|c|c|c|c|c|}
\hline 48 & $\begin{array}{l}\text { Questão referente à legalidade do } \\
\text { Sistema Francês de Amortização, } \\
\text { também conhecido com Tabela Price, } \\
\text { em contrato celebrado no âmbito do } \\
\text { Sistema Financeiro de Habitação. }\end{array}$ & $\begin{array}{l}\text { Nos contratos celebrados no âmbito } \\
\text { do Sistema Financeiro da Habitação, é } \\
\text { vedada a capitalização de juros em } \\
\text { qualquer periodicidade, mas não cabe } \\
\text { ao STJ, todavia, aferir se há } \\
\text { capitalização de juros com a } \\
\text { utilização da Tabela Price, por força } \\
\text { das Súmulas } 5 \text { e } 7 \text {. }\end{array}$ & REsp 1070297/PR & 09/09/2009 \\
\hline 49 & $\begin{array}{l}\text { Questão referente à limitação dos juros } \\
\text { remuneratórios ao percentual de } 10 \% \\
\text { a.a., com base no art. } 6^{\circ} \text {, "e", da Lei n. } \\
4.380 / 64 \text {, em contrato celebrado no } \\
\text { âmbito do Sistema Financeiro de } \\
\text { Habitação. }\end{array}$ & $\begin{array}{l}\mathrm{O} \text { art. } 6^{\circ}, \text { e, da Lei n. } 4.380 / 1964 \text { não } \\
\text { estabelece limitação aos juros } \\
\text { remuneratórios nos contratos } \\
\text { vinculados ao SFH. }\end{array}$ & REsp 1070297/PR & $09 / 09 / 2009$ \\
\hline 52 & $\begin{array}{l}\text { Questão referente à legalidade da } \\
\text { cláusula que, em contratos bancários, } \\
\text { prevê a cobrança da comissão de } \\
\text { permanência na hipótese de } \\
\text { inadimplência do consumidor. }\end{array}$ & $\begin{array}{l}\text { A cobrança de comissão de } \\
\text { permanência - cujo valor não pode } \\
\text { ultrapassar a soma dos encargos } \\
\text { remuneratórios e moratórios previstos } \\
\text { no contrato - exclui a exigibilidade } \\
\text { dos juros remuneratórios, moratórios } \\
\text { e da multa contratual. }\end{array}$ & REsp 1058114/RS & $12 / 08 / 2009$ \\
\hline 53 & $\begin{array}{l}\text { Questiona-se a substituição da Taxa } \\
\text { Referencial - TR - pelo Îndice } \\
\text { Nacional de Preço ao Consumidor - } \\
\text { INPC/IBGE -, como índice de } \\
\text { atualização monetária do saldo } \\
\text { devedor. }\end{array}$ & $\begin{array}{l}\text { No âmbito do Sistema Financeiro da } \\
\text { Habitação, a partir da Lei n. } \\
\text { 8.177/1991, é permitida a utilização } \\
\text { da Taxa Referencial (TR) como índice } \\
\text { de correção monetária do saldo } \\
\text { devedor, que também será cabível } \\
\text { ainda que o contrato tenha sido } \\
\text { firmado antes da Lei n. } 8.177 / 1991, \\
\text { mas desde que haja previsão } \\
\text { contratual de correção monetária pela } \\
\text { taxa básica de remuneração dos } \\
\text { depósitos em poupança, sem nenhum } \\
\text { outro índice específico. }\end{array}$ & REsp 969129/MG & $09 / 12 / 2009$ \\
\hline 54 & $\begin{array}{l}\text { Questiona-se a obrigatoriedade da } \\
\text { contratação de Seguro Habitacional } \\
\text { diretamente com o agente financeiro } \\
\text { ou por seguradora por este indicada. }\end{array}$ & $\begin{array}{l}\text { O mutuário do SFH não pode ser } \\
\text { compelido a contratar o seguro } \\
\text { habitacional obrigatório com a } \\
\text { instituição financeira mutuante ou } \\
\text { com a seguradora por ela indicada. }\end{array}$ & REsp 969129/MG & $09 / 12 / 2009$ \\
\hline 55 & $\begin{array}{l}\text { Questiona-se a possibilidade de tutela } \\
\text { cautelar com vistas a suspender a } \\
\text { execução extrajudicial a que se refere } \\
\text { o Decreto-lei n. } 70 / 66 \text {, bem como de } \\
\text { impedir a inscrição do nome do } \\
\text { devedor em bancos de dados } \\
\text { desabonadores, desde que o mutuário } \\
\text { de contrato celebrado no âmbito do } \\
\text { Sistema Financeiro da Habitação } \\
\text { consigne os valores que entender } \\
\text { devidos. }\end{array}$ & $\begin{array}{l}\text { Em se tratando de contratos } \\
\text { celebrados no âmbito do Sistema } \\
\text { Financeiro da Habitação, a execução } \\
\text { extrajudicial de que trata o Decreto-lei } \\
n^{\circ} 70 / 66 \text {, enquanto perdurar a } \\
\text { demanda, poderá ser suspensa, uma } \\
\text { vez preenchidos os requisitos para a } \\
\text { concessão da tutela cautelar, } \\
\text { independentemente de caução ou do } \\
\text { depósito de valores incontroversos, } \\
\text { desde que: a) exista discussão judicial } \\
\text { contestando a existência integral ou } \\
\text { parcial do débito; b) essa discussão } \\
\text { esteja fundamentada em } \\
\text { jurisprudência do Superior Tribunal } \\
\text { de Justiça ou do Supremo Tribunal } \\
\text { Federal (fumus boni iuris). }\end{array}$ & REsp 1067237/SP & $24 / 06 / 2009$ \\
\hline 57 & $\begin{array}{l}\text { Discute-se, em autos de ação de } \\
\text { cobrança, diferenças de correção } \\
\text { monetária incidentes sobre valores } \\
\text { recolhidos a fundo de previdência } \\
\text { privada, entendeu que a prescrição } \\
\text { incidente à hipótese é vintenária, bem } \\
\text { como pela utilização do IPC como } \\
\text { fator de atualização das parcelas } \\
\text { restituídas. }\end{array}$ & $\begin{array}{l}\text { A ação de cobrança de diferenças de } \\
\text { valores de complementação de } \\
\text { aposentadoria prescreve em cinco } \\
\text { anos contados da data do pagamento. }\end{array}$ & REsp 1110561/SP & $09 / 09 / 2009$ \\
\hline
\end{tabular}




\begin{tabular}{|c|c|c|c|c|}
\hline 58 & $\begin{array}{l}\text { Discute-se, em autos de ação de } \\
\text { cobrança, diferenças de correção } \\
\text { monetária incidentes sobre valores } \\
\text { recolhidos a fundo de previdência } \\
\text { privada, entendeu que a prescrição } \\
\text { incidente à hipótese é vintenária, bem } \\
\text { como pela utilização do IPC como } \\
\text { fator de atualização das parcelas } \\
\text { restituídas. }\end{array}$ & $\begin{array}{l}\text { A ação de cobrança de diferenças de } \\
\text { valores de complementação de } \\
\text { aposentadoria prescreve em cinco } \\
\text { anos contados da data do pagamento. }\end{array}$ & REsp 1110561/SP & 09/09/2009 \\
\hline 59 & $\begin{array}{l}\text { Questiona-se sobre a necessidade de } \\
\text { comprovação, mediante AR, do } \\
\text { recebimento pelo devedor da } \\
\text { correspondência mediante a qual ele é } \\
\text { cientificado previamente da inscrição } \\
\text { de seu nome em cadastros de } \\
\text { inadimplentes. }\end{array}$ & $\begin{array}{l}\text { É dispensável o aviso de recebimento } \\
\text { (AR) na carta de comunicação ao } \\
\text { consumidor sobre a negativação de } \\
\text { seu nome em bancos de dados e } \\
\text { cadastros. }\end{array}$ & REsp 1083291/RS & $09 / 09 / 2009$ \\
\hline 60 & $\begin{array}{l}\text { Questiona-se se diante de ajuizamento } \\
\text { de ação coletiva, pode o Juízo } \\
\text { suspender, ex officio e ao início, o } \\
\text { processo de ação individual } \\
\text { multitudinária atinente à mesma lide, } \\
\text { preservados os efeitos do juizamento } \\
\text { para a futura execução. A suspensão, } \\
\text { no caso de ação multitudinária, não } \\
\text { ofende os dispositivos legais } \\
\text { envolvidos (CDC arts. } 103 \text { e } 104, \S 3^{\circ} \text {; } \\
\text { CPC, arts. } 2^{\circ} \text { e } 6^{\circ} \text {; e CC, arts. } 122 \text { e } \\
166) \text {. }\end{array}$ & $\begin{array}{l}\text { Ajuizada ação coletiva atinente a } \\
\text { macro-lide geradora de processos } \\
\text { multitudinários, suspendem-se as } \\
\text { ações individuais, no aguardo do } \\
\text { julgamento da ação coletiva. }\end{array}$ & REsp 1110549/RS & $28 / 10 / 2009$ \\
\hline 61 & $\begin{array}{l}\text { Questiona-se a configuração ou não de } \\
\text { denúncia espontânea relativamente a } \\
\text { tributo estadual sujeito a lançamento } \\
\text { por homologação (ICMS), declarado } \\
\text { pelo contribuinte (em Guia de } \\
\text { Informação e Apuração - GIA), mas } \\
\text { pago no devido prazo. }\end{array}$ & $\begin{array}{l}\text { Não resta caracterizada a denúncia } \\
\text { espontânea, com a consequente } \\
\text { exclusão da multa moratória, nos } \\
\text { casos de tributos declarados, porém } \\
\text { pagos a destempo pelo contribuinte, } \\
\text { ainda que o pagamento seja integral. }\end{array}$ & REsp 886462/RS & $22 / 10 / 2008$ \\
\hline 62 & $\begin{array}{l}\text { Questiona-se, tendo em vista a Lei } \\
7.713 / 88 \text {, a cobrança de imposto de } \\
\text { renda sobre pagamento de benefício de } \\
\text { complementação de aposentadoria, } \\
\text { decorrente de plano de previdência } \\
\text { privada. }\end{array}$ & $\begin{array}{l}\text { Por força da isenção concedida pelo } \\
\text { art. } 6^{\circ}, \text { VII, b, da Lei } 7.713 / 88, \text { na } \\
\text { redação anterior à que lhe foi dada } \\
\text { pela Lei } 9.250 / 95 \text {, é indevida a } \\
\text { cobrança de imposto de renda sobre o } \\
\text { valor da complementação de } \\
\text { aposentadoria e o do resgate de } \\
\text { contribuições correspondentes a } \\
\text { recolhimentos para entidade de } \\
\text { previdência privada ocorridos no } \\
\text { período de } 1^{\circ} .01 .1989 \text { a } 31.12 .1995 .\end{array}$ & REsp 1012903/RJ & $08 / 10 / 2008$ \\
\hline 63 & $\begin{array}{l}\text { Questiona-se a legitimidade da } \\
\text { cobrança de ICMS sobre o valor pago } \\
\text { a título de "demanda contratada" de } \\
\text { energia elétrica. }\end{array}$ & $\begin{array}{l}\text { É indevida a incidência de ICMS } \\
\text { sobre a parcela correspondente à } \\
\text { demanda de potência elétrica } \\
\text { contratada mas não utilizada. }\end{array}$ & REsp 960476/SC & $11 / 03 / 2009$ \\
\hline 64 & $\begin{array}{l}\text { Questão referente ao empréstimo } \\
\text { compulsório sobre energia elétrica, no } \\
\text { qual se discute: a) prescrição - termo a } \\
\text { quo; b) correção monetária plena sobre } \\
\text { o principal (a partir da data do } \\
\text { recolhimento até a data do efetivo } \\
\text { pagamento de juros e de } 31 \text { de } \\
\text { dezembro até a data da assembléia de } \\
\text { conversão), bem como o reflexo dos } \\
\text { juros de } 6 \% \text { ao ano sobre a diferença } \\
\text { de correção monetária; c) juros } \\
\text { remuneratórios de } 6 \% \text { ao ano; d) taxa } \\
\text { SELIC; e e) juros moratórios. }\end{array}$ & $\begin{array}{l}\text { Quanto à pretensão da incidência de } \\
\text { correção monetária sobre os juros } \\
\text { remuneratórios de que trata o art. } 2^{\circ} \\
\text { do Decreto-lei } 1.512 / 76 \text { (item } 3 \text { ), a } \\
\text { lesão ao direito do consumidor } \\
\text { ocorreu, efetivamente, em julho de } \\
\text { cada ano vencido, no momento em } \\
\text { que a ELETROBRÁS realizou o } \\
\text { pagamento da respectiva parcela, } \\
\text { mediante compensação dos valores } \\
\text { nas contas de energia elétrica. }\end{array}$ & REsp 1003955/RS & $12 / 08 / 2009$ \\
\hline
\end{tabular}


65 Questão referente ao empréstimo compulsório sobre energia elétrica, no qual se discute: a) prescrição - termo a quo; b) correção monetária plena sobre o principal (a partir da data do recolhimento até a data do efetivo pagamento de juros e de 31 de dezembro até a data da assembléia de conversão), bem como o reflexo dos juros de $6 \%$ ao ano sobre a diferença de correção monetária; c) juros remuneratórios de $6 \%$ ao ano; d) taxa SELIC; e e) juros moratórios.
66 Questão referente ao empréstimo compulsório sobre energia elétrica, no qual se discute: a) prescrição - termo a quo; b) correção monetária plena sobre o principal (a partir da data do recolhimento até a data do efetivo pagamento de juros e de 31 de dezembro até a data da assembléia de conversão), bem como o reflexo dos juros de $6 \%$ ao ano sobre a diferença de correção monetária; c) juros remuneratórios de $6 \%$ ao ano; d) taxa SELIC; e e) juros moratórios.

67 Questão referente ao empréstimo compulsório sobre energia elétrica, no qual se discute: a) prescrição - termo a quo; b) correção monetária plena sobre o principal (a partir da data do recolhimento até a data do efetivo pagamento de juros e de 31 de dezembro até a data da assembléia de conversão), bem como o reflexo dos juros de $6 \%$ ao ano sobre a diferença de correção monetária; c) juros remuneratórios de $6 \%$ ao ano; d) taxa SELIC; e e) juros moratórios.

Questão referente ao empréstimo compulsório sobre energia elétrica, no qual se discute: a) prescrição - termo a quo; b) correção monetária plena sobre o principal (a partir da data do recolhimento até a data do efetivo pagamento de juros e de 31 de dezembro até a data da assembléia de conversão), bem como o reflexo dos juros de $6 \%$ ao ano sobre a diferença de correção monetária; c) juros remuneratórios de $6 \%$ ao ano; d) taxa SELIC; e e) juros moratórios.
Quanto à pretensão de correção monetária incidente sobre o principal (item 2), e dos juros remuneratórios dela decorrentes (item 4), a lesão ao direito do consumidor somente ocorreu no momento da restituição do empréstimo em valor 'a menor'.

Considerando que essa restituição se deu em forma de conversão dos créditos em ações da companhia, a prescrição teve início na data em que a Assembleia-Geral Extraordinária homologou a conversão a saber: a) 20/04/1988 - com a $72^{\mathrm{a}} \mathrm{AGE}-1^{\mathrm{a}}$ conversão; b) 26/04/1990 - com a $82^{\mathrm{a}}$ AGE - $2^{a}$ conversão; e c) 30/06/2005 com a $143^{\mathrm{a}}$ AGE - $3^{\mathrm{a}}$ conversão.

Quanto à pretensão de correção monetária incidente sobre o principal (item 2), e dos juros remuneratórios dela decorrentes (item 4), a lesão ao direito do consumidor somente ocorreu no momento da restituição do empréstimo em valor 'a menor'.

Considerando que essa restituição se deu em forma de conversão dos créditos em ações da companhia, a prescrição teve início na data em que a Assembleia-Geral Extraordinária homologou a conversão a saber: a) 20/04/1988 - com a $72^{\mathrm{a}} \mathrm{AGE}-1^{\mathrm{a}}$ conversão; b) 26/04/1990 - com a $82^{\mathrm{a}}$ AGE - $2^{\mathrm{a}}$ conversão; e c) 30/06/2005 com a $143^{\mathrm{a}} \mathrm{AGE}-3^{\mathrm{a}}$ conversão.

Quanto à pretensão de correção monetária incidente sobre o principal (item 2), e dos juros remuneratórios dela decorrentes (item 4), a lesão ao direito do consumidor somente ocorreu no momento da restituição do empréstimo em valor 'a menor'. Considerando que essa restituição se deu em forma de conversão dos créditos em ações da companhia, a prescrição teve início na data em que a Assembleia-Geral Extraordinária homologou a conversão a saber: a) 20/04/1988 - com a $72^{\mathrm{a}}$ AGE - $1^{\mathrm{a}}$ conversão; b) 26/04/1990 - com a $82^{a}$ AGE - $2^{\mathrm{a}}$ conversão; e c) 30/06/2005 com a $143^{\mathrm{a}}$ AGE - $3^{\mathrm{a}}$ conversão. Os valores compulsoriamente recolhidos devem ser devolvidos com correção monetária plena (integral), não havendo motivo para a supressão da atualização no período decorrido entre a data do recolhimento e o $1^{\circ}$ dia do ano subsequente, que deve obedecer à regra do art. $7^{\circ}, \S 1^{\circ}$, da Lei 4.357/64 e, a partir daí, o critério anual previsto no art. $3^{\circ}$ da mesma lei. Devem ser computados, ainda, os expurgos inflacionários, conforme pacificado na jurisprudência do STJ, o que não importa em ofensa ao art. $3^{\circ}$ da Lei 4.357/64. Entretanto, descabida a incidência de correção monetária em

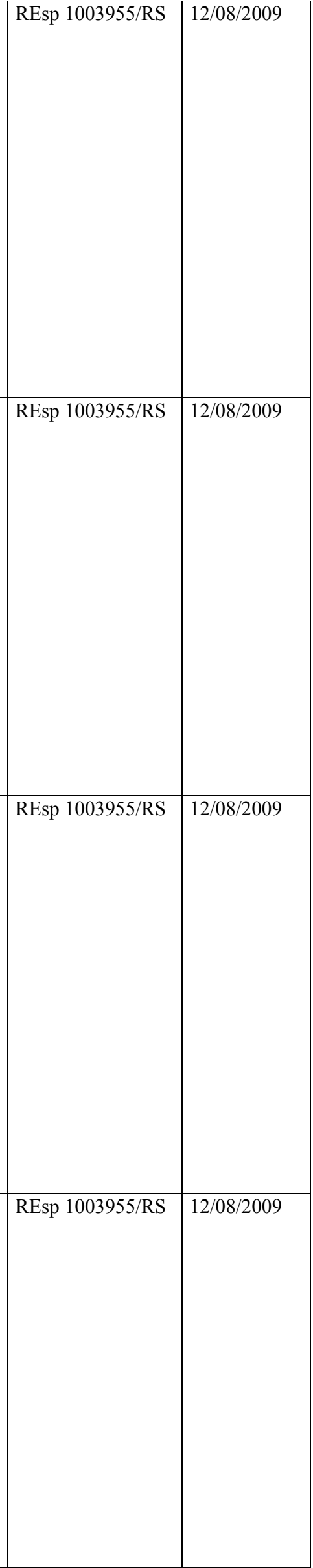


69 Questão referente ao empréstimo compulsório sobre energia elétrica, no qual se discute: a) prescrição - termo a quo; b) correção monetária plena sobre o principal (a partir da data do recolhimento até a data do efetivo pagamento de juros e de 31 de dezembro até a data da assembléia de conversão), bem como o reflexo dos juros de $6 \%$ ao ano sobre a diferença de correção monetária; c) juros remuneratórios de $6 \%$ ao ano; d) taxa SELIC; e e) juros moratórios.

70 Questão referente ao empréstimo compulsório sobre energia elétrica, no qual se discute: a) prescrição - termo a quo; b) correção monetária plena sobre o principal (a partir da data do recolhimento até a data do efetivo pagamento de juros e de 31 de dezembro até a data da assembléia de conversão), bem como o reflexo dos juros de $6 \%$ ao ano sobre a diferença de correção monetária; c) juros remuneratórios de $6 \%$ ao ano; d) taxa SELIC; e e) juros moratórios.

71 Questão referente ao empréstimo compulsório sobre energia elétrica, no qual se discute: a) prescrição - termo a quo; b) correção monetária plena sobre o principal (a partir da data do recolhimento até a data do efetivo pagamento de juros e de 31 de dezembro até a data da assembléia de conversão), bem como o reflexo dos juros de $6 \%$ ao ano sobre a diferença de correção monetária; c) juros remuneratórios de $6 \%$ ao ano; d) taxa SELIC; e e) juros moratórios.

72 Questão referente ao empréstimo compulsório sobre energia elétrica, no qual se discute: a) prescrição - termo a quo; b) correção monetária plena sobre o principal (a partir da data do recolhimento até a data do efetivo pagamento de juros e de 31 de dezembro até a data da assembléia de conversão), bem como o reflexo dos juros de $6 \%$ ao ano sobre a diferença de correção monetária; c) juros remuneratórios de $6 \%$ ao ano; d) taxa SELIC; e e) juros moratórios. relação ao período compreendido entre $31 / 12$ do ano anterior à conversão e a data da assembleia de homologação.

Devida, em tese, a atualização

monetária sobre juros remuneratórios em razão da ilegalidade do pagamento em julho de cada ano, sem incidência de atualização entre a data da constituição do crédito em $31 / 12$ do ano anterior e o efetivo pagamento, observada a prescrição quinquenal.

São devidos juros remuneratórios de $6 \%$ ao ano (art. $2^{\circ}$ do Decreto-lei $1.512 / 76)$ sobre a diferença de correção monetária (incluindo-se os expurgos inflacionários) incidente sobre o principal (apurada da data do recolhimento até $31 / 12$ do mesmo ano). Cabível o pagamento dessas diferenças à parte autora em dinheiro ou na forma de participação acionária (ações preferenciais nominativas), a critério da ELETROBRÁS, tal qual ocorreu em relação ao principal, nos termos do Decreto-lei 1.512/76.

Os valores objeto da condenação judicial ficam sujeitos a correção monetária, a contar da data em que deveriam ter sido pagos: a) quanto à condenação referente às diferenças de correção monetária paga a menor sobre empréstimo compulsório, e os juros remuneratórios dela decorrentes (itens 2 e 4 supra), o débito judicial deve ser corrigido a partir da data da correspondente assembleia-geral de homologação da conversão em ações.

Os valores objeto da condenação judicial ficam sujeitos a correção monetária, a contar da data em que deveriam ter sido pagos: b) quanto à diferença de juros remuneratórios (item 4 supra), o débito judicial deve ser corrigido a partir do mês de julho do ano em que os juros deveriam ter sido pagos.

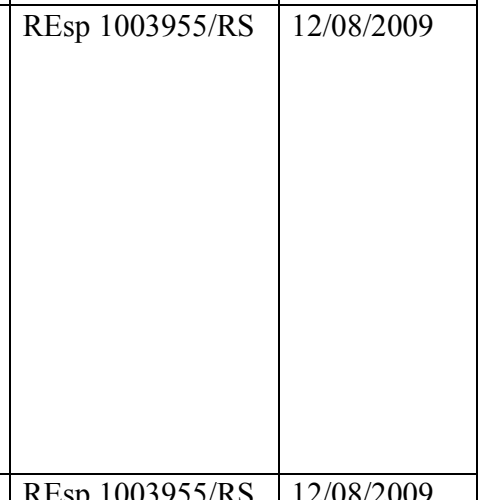

REsp 1003955/RS $12 / 08 / 2009$

REsp 1003955/RS 12/08/2009


73 Questão referente ao empréstimo compulsório sobre energia elétrica, no qual se discute: a) prescrição - termo a quo; b) correção monetária plena sobre o principal (a partir da data do recolhimento até a data do efetivo pagamento de juros e de 31 de dezembro até a data da assembléia de conversão), bem como o reflexo dos juros de $6 \%$ ao ano sobre a diferença de correção monetária; c) juros remuneratórios de $6 \%$ ao ano; d) taxa SELIC; e e) juros moratórios.

74 Questão referente ao empréstimo compulsório sobre energia elétrica, no qual se discute: a) prescrição - termo a quo; b) correção monetária plena sobre o principal (a partir da data do recolhimento até a data do efetivo pagamento de juros e de 31 de dezembro até a data da assembléia de conversão), bem como o reflexo dos juros de $6 \%$ ao ano sobre a diferença de correção monetária; c) juros remuneratórios de $6 \%$ ao ano; d) taxa SELIC; e e) juros moratórios.

75 Questão referente ao empréstimo compulsório sobre energia elétrica, no qual se discute: a) prescrição - termo a quo; b) correção monetária plena sobre o principal (a partir da data do recolhimento até a data do efetivo pagamento de juros e de 31 de dezembro até a data da assembléia de conversão), bem como o reflexo dos juros de $6 \%$ ao ano sobre a diferença de correção monetária; c) juros remuneratórios de $6 \%$ ao ano; d) taxa SELIC; e e) juros moratórios.

76 Questona-se a existência ou não, de legitimidade ou não da cobrança da tarifa de assinatura mensal relativa à prestação de serviços de telefonia, de litisconsórcio passivo necessário entre a empresa concessionária de telefonia e a ANATEL.

77 Questiona-se a legitimidade ou não da cobrança da tarifa de assinatura mensal relativa à prestação de serviços de telefonia.

78 Questão referente ao empréstimo compulsório sobre energia elétrica, no qual se discute: a) prescrição - termo a quo; b) correção monetária plena sobre o principal (a partir da data do recolhimento até a data do efetivo pagamento de juros e de 31 de dezembro até a data da assembléia de conversão), bem como o reflexo dos juros de $6 \%$ ao ano sobre a diferença de correção monetária; c) juros
ÍNDICES: observado o Manual de Cálculos da Justiça Federal e a jurisprudência do STJ, cabível o cômputo dos seguintes expurgos inflacionários em substituição aos índices oficiais já aplicados: 14,36\% (fevereiro/86), 26,06\% (junho/87), $42,72 \%$ (janeiro/89), 10,14\% (fevereiro/89), 84,32\% (março/90), 44,80\% (abril/90), 7,87\% (maio/90), 9,55\% (junho/90), 12,92\% (julho/90), $12,03 \%$ (agosto/90), 12,76\% (setembro/90), 14,20\% (outubro/90), $15,58 \%$ (novembro/90), $18,30 \%$ (dezembro/90), 19,91\% (janeiro/91), $21,87 \%$ (fevereiro/91) e $1,79 \%$ (março/91).

Sobre os valores apurados em liquidação de sentença devem incidir, até o efetivo pagamento, correção monetária e juros moratórios a partir da citação: a) de $6 \%$ ao ano, até 11/01/2003 (quando entrou em vigor o novo Código Civil) - arts. $1.062 \mathrm{e}$ 1.063 do CC/1916; b) a partir da vigência do $C C / 2002$, deve incidir a taxa que estiver em vigor para a mora do pagamento de impostos devidos à Fazenda Nacional. Segundo a jurisprudência desta Corte, o índice a que se refere o dispositivo é a taxa SELIC.

Considerando que a taxa SELIC, em sua essência, já compreende juros de mora e atualização monetária, a partir de sua incidência não há cumulação desse índice com juros de mora.

\begin{tabular}{|c|c|c|}
\hline $\begin{array}{l}\text { Em demandas sobre a legitimidade da } \\
\text { cobrança de tarifas por serviço de } \\
\text { telefonia, movidas por usuário contra } \\
\text { a concessionária, não se configura } \\
\text { hipótese de litisconsórcio passivo } \\
\text { necessário da ANATEL. }\end{array}$ & REsp 1068944/PB & $12 / 11 / 2008$ \\
\hline $\begin{array}{l}\text { É legítima a cobrança de tarifa básica } \\
\text { pelo uso dos serviços de telefonia } \\
\text { fixa. }\end{array}$ & REsp 1068944/PB & $12 / 11 / 2008$ \\
\hline $\begin{array}{l}\text { Cabível a conversão dos créditos em } \\
\text { ações pelo valor patrimonial e não } \\
\text { pelo valor de mercado, por expressa } \\
\text { disposição legal (art. } 4^{\circ} \text { da Lei } \\
7.181 / 83 \text { ). }\end{array}$ & REsp 1028592/RS & $12 / 08 / 2009$ \\
\hline
\end{tabular}

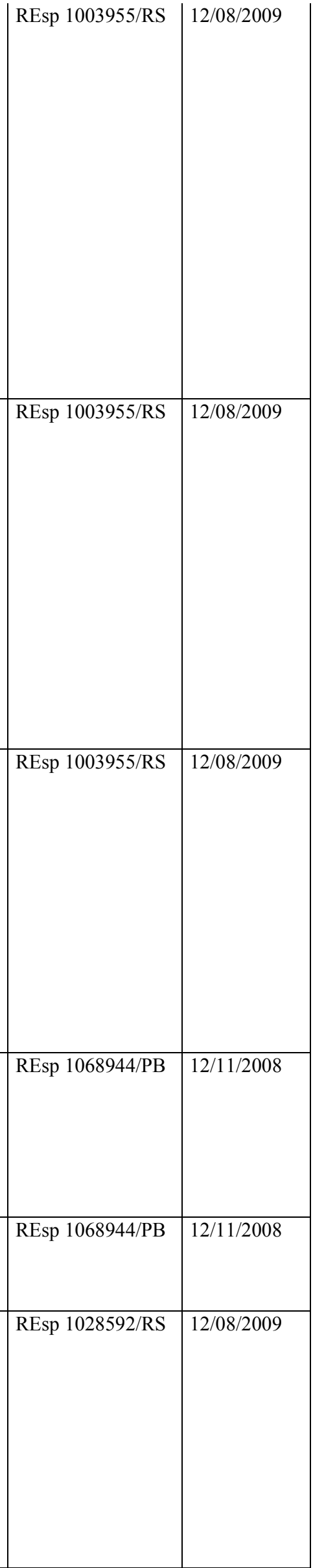




\begin{tabular}{|c|c|c|c|c|}
\hline & $\begin{array}{l}\text { remuneratórios de } 6 \% \text { ao ano; d) taxa } \\
\text { SELIC; e e) juros moratórios. }\end{array}$ & & & \\
\hline 79 & $\begin{array}{l}\text { Questiona-se se a forma de intimação } \\
\text { do ato que exclui o contribuinte do } \\
\text { Programa de Recuperação Fiscal - } \\
\text { REFIS, a saber, se necessário ato } \\
\text { publicado no DOU, ou suficiente } \\
\text { comunicação pela via da internet, nos } \\
\text { termos da Lei } 9.964 / 00 \text {, art. } 9^{\circ} \text {, III, c/c } \\
\text { art. } 5^{\circ} \text { da Resolução } 20 / 2001 \text { do } \\
\text { Comitê Gestor. }\end{array}$ & $\begin{array}{l}\text { O art. } 5^{\circ} \text { da Resolução } 20 / 2001 \text { do } \\
\text { Comitê Gestor do Programa prevê a } \\
\text { notificação da exclusão do REFIS por } \\
\text { meio de publicação no Diário Oficial } \\
\text { ou pela Internet, o que torna } \\
\text { desarrazoada a pretensão de intimação } \\
\text { pessoal para esta finalidade. }\end{array}$ & REsp 1046376/DF & $11 / 02 / 2009$ \\
\hline 80 & $\begin{array}{l}\text { Questão referente à legalidade da } \\
\text { retenção de } 11 \% \text { sobre os valores } \\
\text { brutos das faturas dos contratos de } \\
\text { prestação de serviço pelas empresas } \\
\text { tomadoras, conforme disposição do } \\
\text { art. } 31 \text { da Lei } 9.711 / 98 \text {. }\end{array}$ & $\begin{array}{l}\text { A retenção de } 11 \% \text { (onze por cento) a } \\
\text { título de contribuição previdenciária, } \\
\text { na forma do art. } 31 \text { da Lei n. } \\
8.212 / 91 \text {, não configura nova } \\
\text { modalidade de tributo, mas tão- } \\
\text { somente alteração na sua forma de } \\
\text { recolhimento, não havendo nenhuma } \\
\text { ilegalidade nessa nova sistemática de } \\
\text { arrecadação. }\end{array}$ & REsp 1036375/SP & $11 / 03 / 2009$ \\
\hline 81 & $\begin{array}{l}\text { Questão referente à compensação, em } \\
\text { sede de embargos à execução, de } \\
\text { valores retidos na fonte, a título de } \\
\text { imposto de renda, com aqueles } \\
\text { restituídos, quando do ajuste anual das } \\
\text { declarações dos exeqüentes. }\end{array}$ & $\begin{array}{l}\text { É admissível, em embargos à } \\
\text { execução, compensar os valores de } \\
\text { imposto de renda retidos } \\
\text { indevidamente na fonte com os } \\
\text { valores restituídos apurados na } \\
\text { declaração anual. } \\
\end{array}$ & REsp 1001655/DF & $11 / 03 / 2009$ \\
\hline 82 & $\begin{array}{l}\text { Questão referente à possibilidade de } \\
\text { interrupção da prescrição por meio de } \\
\text { citação por edital em ação de execução } \\
\text { fiscal. }\end{array}$ & $\begin{array}{l}\text { A citação válida, ainda que por edital, } \\
\text { tem o condão de interromper o fluxo } \\
\text { do prazo prescricional. }\end{array}$ & REsp 999901/RS & $13 / 05 / 2009$ \\
\hline 83 & $\begin{array}{l}\text { Questão referente à exigibilidade da } \\
\text { contribuição adicional destinada ao } \\
\text { Instituto Nacional de Colonização e } \\
\text { Reforma Agrária - INCRA, criada pela } \\
\text { Lei } \mathrm{n}^{\circ} 2.613 / 55 \text {, cobrada no importe de } \\
0,2 \% \text { sobre folha de salário. }\end{array}$ & $\begin{array}{l}\text { A parcela de } 0,2 \% \text { (zero vírgula dois } \\
\text { por cento) - destinada ao Incra não foi } \\
\text { extinta pela Lei } 7.787 / 89 \text { e tampouco } \\
\text { pela Lei } 8.213 / 91 \text {. }\end{array}$ & REsp 977058/RS & $22 / 10 / 2008$ \\
\hline 84 & $\begin{array}{l}\text { Questão referente ao fornecimento de } \\
\text { medicamento necessário ao tratamento } \\
\text { de saúde, sob pena de bloqueio ou } \\
\text { seqüestro de verbas do Estado a serem } \\
\text { depositadas em conta-corrente. }\end{array}$ & $\begin{array}{l}\text { Tratando-se de fornecimento de } \\
\text { medicamentos, cabe ao Juiz adotar } \\
\text { medidas eficazes à efetivação de suas } \\
\text { decisões, podendo, se necessário, } \\
\text { determinar até mesmo o sequestro de } \\
\text { valores do devedor (bloqueio), } \\
\text { segundo o seu prudente arbítrio, e } \\
\text { sempre com adequada } \\
\text { fundamentação. }\end{array}$ & REsp 1069810/RS & $23 / 10 / 2013$ \\
\hline 85 & $\begin{array}{l}\text { Questão referente à aplicação da } \\
\text { multa, juros e correção monetária a } \\
\text { partir do vencimento da contribuição } \\
\text { sindical rural, no caso de seu } \\
\text { recolhimento extemporâneo, conforme } \\
\text { disposição do art. } 600 \text { da CLT. }\end{array}$ & $\begin{array}{l}\text { A contribuição sindical rural } \\
\text { implementada a destempo sofre a } \\
\text { incidência do regime previsto no art. } \\
2^{\circ} \text { da Lei } 8.022 / 90 \text {, reiterado pelo art. } \\
59 \text { da Lei } 8.383 / 91 \text {. }\end{array}$ & REsp 902349/PR & $24 / 06 / 2009$ \\
\hline
\end{tabular}




\begin{tabular}{|c|c|c|c|c|}
\hline 86 & $\begin{array}{l}\text { Questão referente ao processamento de } \\
\text { recurso administrativo sem o depósito } \\
\text { prévio de } 30 \% \text { (trinta por cento) da } \\
\text { exigência fiscal, instituído pelo } \S 1^{\circ} \text {, } \\
\text { do artigo } 126 \text {, da Lei } 8.213 / 91, \\
\text { acrescentado pela Medida Provisória } \\
n^{\circ} 1.607-12 / 98 \text {, convertida na Lei } n^{\circ} \\
9.639 / 98 \text {. }\end{array}$ & $\begin{array}{l}\text { O depósito prévio ao recurso } \\
\text { administrativo, para a discussão de } \\
\text { crédito previdenciário, ante o } \\
\text { flagrante desrespeito à garantia } \\
\text { constitucional da ampla defesa (artigo } \\
5^{\circ}, \mathrm{LV}, \text { da CF/88) e ao direito de } \\
\text { petição independentemente do } \\
\text { pagamento de taxas (artigo } 5^{\circ}, \\
\text { XXXIV, "a", da CF/88) é inexigível, } \\
\text { consoante decisão do Supremo } \\
\text { Tribunal Federal, na sessão plenária } \\
\text { ocorrida em } 28.03 .2007, \text { nos autos do } \\
\text { Recurso Extraordinário } 389.383-1 / \mathrm{SP}, \\
\text { na qual declarou, por maioria, a } \\
\text { inconstitucionalidade dos } \S \S 1 .^{\circ} \text { e } 2 .^{\circ}, \\
\text { do artigo } 126, \text { da Lei } 8.213 / 91, \text { com a } \\
\text { redação dada pela Medida Provisória } \\
\text { 1.608-14/98, convertida na Lei } \\
\text { 9.639/98. }\end{array}$ & REsp 894060/SP & $22 / 10 / 2008$ \\
\hline 87 & $\begin{array}{l}\text { Questão referente à legalidade da } \\
\text { cobrança de pulsos excedentes à } \\
\text { franquia telefônica, sem a } \\
\text { discriminação das ligações. }\end{array}$ & $\begin{array}{l}\text { A partir de } 01 \text { de Agosto de } 2007, \\
\text { data da implementação total do } \\
\text { sistema, passou a ser exigido das } \\
\text { concessionárias o detalhamento de } \\
\text { todas as ligações na modalidade local, } \\
\text { independentemente de ser dentro ou } \\
\text { fora da franquia contratada, por } \\
\text { inexistir qualquer restrição a respeito, } \\
\text { conforme se observa do constante do } \\
\text { artigo } 83 \text { do anexo à Resolução } \\
426 / 2005 \text {, que regulamentou o } \\
\text { sistema de telefonia fixa. } \\
\end{array}$ & REsp 1074799/MG & $27 / 05 / 2009$ \\
\hline 88 & $\begin{array}{l}\text { Questiona-se o termo inicial da } \\
\text { incidência dos juros moratórios em } \\
\text { demanda objetivando a restituição de } \\
\text { contribuição previdenciária de } \\
\text { servidor público inativo. }\end{array}$ & $\begin{array}{l}\text { Nos termos do art. 167, parágrafo } \\
\text { único do CTN e da Súmula 188/STJ, } \\
\text { 'Os juros moratórios, na repetição do } \\
\text { indébito tributário, são devidos a } \\
\text { partir do trânsito em julgado da } \\
\text { sentença'. Tal regime é aplicável à } \\
\text { repetição de indébito de contribuições } \\
\text { previdenciárias, que também têm } \\
\text { natureza tributária. }\end{array}$ & REsp 1086935/SP & $12 / 11 / 2008$ \\
\hline 89 & $\begin{array}{l}\text { Questão referente à existência ou não } \\
\text { de isenção do ICMS sobre o bacalhau } \\
\text { oriundo de país signatário do GATT - } \\
\text { General Agreement on Tariffs and } \\
\text { Trade. }\end{array}$ & $\begin{array}{l}\text { As operações de importação de } \\
\text { bacalhau (peixe seco e salgado, } \\
\text { espécie do gênero pescado), } \\
\text { provenientes de países signatários do } \\
\text { GATT - General Agreement on } \\
\text { Tariffs and Trade, realizadas até } 30 \text { de } \\
\text { abril de } 1999 \text {, são isentas de } \\
\text { recolhimento do ICMS. }\end{array}$ & REsp 871760/BA & $11 / 03 / 2009$ \\
\hline 90 & $\begin{array}{l}\text { Questiona-se, tendo em vista a Lei } \\
7.713 / 88, \text { a cobrança de imposto de } \\
\text { renda sobre valores recebidos em } \\
\text { decorrência do rateio do patrimônio de } \\
\text { entidade de previdência privada. }\end{array}$ & $\begin{array}{l}\text { Por força da isenção concedida pelo } \\
\text { art. } 6^{\circ}, \text { VII, b, da Lei } 7.713 / 88, \text { na } \\
\text { redação anterior à que lhe foi dada } \\
\text { pela Lei } 9.250 / 95 \text {, é indevida a } \\
\text { cobrança de imposto de renda sobre o } \\
\text { valor da complementação de } \\
\text { aposentadoria e o do resgate de } \\
\text { contribuições correspondentes a } \\
\text { recolhimentos para entidade de } \\
\text { previdência privada ocorridos no } \\
\text { período de } 1^{\circ} .01 .1989 \text { a } 31.12 .1995 . \\
\text { A quantia que couber por rateio a } \\
\text { cada participante, superior ao valor } \\
\text { das respectivas contribuições, } \\
\text { constitui acréscimo patrimonial } \\
\text { (CTN, art. } 43) \text { e, como tal, atrai a } \\
\text { incidência de imposto de renda. }\end{array}$ & REsp 760246/PR & $10 / 12 / 2008$ \\
\hline
\end{tabular}


91 Questiona-se a incidência do ICMS na operação de fornecimento de embalagens sob encomenda associada ao serviço de composição gráfica.
92 Questão referente às OBRIGAÇÕES AO PORTADOR emitidas pela ELETROBRÁS na forma da Lei 4.156/62 (com a redação dada pelo DL 644/69), em que pleiteia a restituição dos valores cobrados a título de empréstimo compulsório sobre energia elétrica, acrescidos de correção monetária plena e juros.
As operações de composição gráfica, como no caso de impressos personalizados e sob encomenda, são de natureza mista, sendo que os serviços a elas agregados estão incluídos na Lista Anexa ao DecretoLei 406/68 (item 77) e à LC 116/03 (item 13.05). Consequentemente, tais operações estão sujeitas à incidência de ISSQN (e não de ICMS).

Confirma-se o entendimento da Súmula 156/STJ: 'A prestação de serviço de composição gráfica, personalizada e sob encomenda, ainda que envolva fornecimento de mercadorias, está sujeita, apenas, ao ISS.

As OBRIGAÇÕES AO PORTADOR emitidas pela ELETROBRÁS em razão do empréstimo compulsório instituído pela Lei 4.156/62 não se confundem com as DEBÊNTURES e, portanto, não se aplica a regra do art. 442 do CCom, segundo o qual prescrevem em 20 anos as ações fundadas em obrigações comerciais contraídas por escritura pública ou particular. Não se trata de obrigação de natureza comercial, mas de relação de direito administrativo a estabelecida entre a ELETROBRÁS (delegada da União) e o titular do crédito, aplicando-se, em tese, a regra do Decreto 20.910/32.

93 Questão referente às OBRIGAÇÕES AO PORTADOR emitidas pela ELETROBRÁS na forma da Lei 4.156/62 (com a redação dada pelo DL 644/69), em que pleiteia a restituição dos valores cobrados a título de empréstimo compulsório sobre energia elétrica, acrescidos de correção monetária plena e juros.

94 Questão referente às OBRIGAÇÕES AO PORTADOR emitidas pela ELETROBRÁS na forma da Lei 4.156/62 (com a redação dada pelo DL 644/69), em que pleiteia a restituição dos valores cobrados a título de empréstimo compulsório sobre energia elétrica, acrescidos de correção monetária plena e juros.

95 Questão referente à legitimidade passiva ad causam do Banco Central do Brasil-BACEN para responder pela correção monetária dos cruzados novos retidos pela implantação do Plano Collor.
$\mathrm{O}$ direito ao resgate configura-se direito potestativo e, portanto, a regra do art. $4^{\circ}, \S 11$, da Lei 4.156/62, que estabelece o prazo de 5 anos, tanto para o consumidor efetuar a troca das contas de energia por OBRIGAÇÕES AO PORTADOR, quanto para, posteriormente, efetuar o resgate, fixa prazo decadencial e não prescricional. Como o art. $4^{\circ}, \S 10$, da Lei 4.156/62 (acrescido pelo DL 644/69) conferiu à ELETROBRÁS a faculdade de proceder à troca das obrigações por ações preferenciais, não exercida essa faculdade, o titular do crédito somente teria direito, em tese, à devolução em dinheiro.

Os bancos depositários são responsáveis pela correção monetária dos ativos retidos até o momento em que esses foram transferidos ao Banco Central do Brasil. Consequentemente, os bancos depositários são legitimados passivos quanto à pretensão de reajuste dos saldos referente ao mês de março de 1990 , bem como ao pertinente ao mês de abril do mesmo ano, referente às contas de poupança cujas datas de aniversário ou creditamento foram anteriores à transferência dos ativos.
REsp 1092206/SP |11/03/2009

REsp 1050199/RJ 10/12/2008

\begin{tabular}{l|l} 
REsp 1050199/RJ 10/12/2008 & 100
\end{tabular}

\begin{tabular}{|l|l|}
\hline REsp 1050199/RJ & $10 / 12 / 2008$ \\
\hline REsp 1070252/SP & $27 / 05 / 2009$ \\
& \\
&
\end{tabular}




\begin{tabular}{|c|c|c|c|c|}
\hline 96 & $\begin{array}{l}\text { Questiona-se a responsabilidade dos } \\
\text { sócios para responder por débitos da } \\
\text { pessoa jurídica devedora em execução } \\
\text { fiscal. }\end{array}$ & $\begin{array}{l}\text { A entrega de declaração pelo } \\
\text { contribuinte reconhecendo débito } \\
\text { fiscal constitui o crédito tributário, } \\
\text { dispensada qualquer outra providência } \\
\text { por parte do fisco. }\end{array}$ & REsp 1101728/SP & $11 / 03 / 2009$ \\
\hline 97 & $\begin{array}{l}\text { Questiona-se a responsabilidade dos } \\
\text { sócios para responder por débitos da } \\
\text { pessoa jurídica devedora em execução } \\
\text { fiscal. }\end{array}$ & $\begin{array}{l}\text { A simples falta de pagamento do } \\
\text { tributo não configura, por si só, nem } \\
\text { em tese, circunstância que acarreta a } \\
\text { responsabilidade subsidiária do sócio, } \\
\text { prevista no art. } 135 \text { do CTN. É } \\
\text { indispensável, para tanto, que tenha } \\
\text { agido com excesso de poderes ou } \\
\text { infração à lei, ao contrato social ou ao } \\
\text { estatuto da empresa. }\end{array}$ & REsp 1101728/SP & $11 / 03 / 2009$ \\
\hline 99 & $\begin{array}{l}\text { Questiona-se a incidência da Taxa } \\
\text { SELIC a título de juros de mora na } \\
\text { atualização da conta vinculada do } \\
\text { FGTS. }\end{array}$ & $\begin{array}{l}\text { Relativamente aos juros moratórios a } \\
\text { que está sujeita a CEF - por não ter } \\
\text { efetuado, no devido tempo e pelo } \\
\text { índice correto, os créditos de correção } \\
\text { monetária das contas vinculadas do } \\
\text { FGTS -, seu cálculo deve observar, à } \\
\text { falta de norma específica, a taxa legal, } \\
\text { antes prevista no art. } 1062 \text { do Código } \\
\text { Civil de } 1916 \text { e agora no art. } 406 \text { do } \\
\text { Código Civil de 2002. (...) } \\
\text { "atualmente, a taxa dos juros } \\
\text { moratórios a que se refere o referido } \\
\text { dispositivo [art. 406 do CC/2002] é a } \\
\text { taxa referencial do Sistema Especial } \\
\text { de Liquidação e Custódia - SELIC", } \\
\text { que "não pode ser cumulada com a } \\
\text { aplicação de outros índices de } \\
\text { atualização monetária. }\end{array}$ & REsp 1102552/CE & $25 / 03 / 2009$ \\
\hline 100 & $\begin{array}{l}\text { Questão referente à ofensa ao art. } 40, \S \\
4^{\circ}, \text { da Lei } n^{\circ} 6.830 / 80, \text { por entender } \\
\text { que o referido } \S 4^{\circ} \text { deve ser } \\
\text { interpretado em consonância com o } \\
\text { caput do art. } 40 \text { e com os demais } \\
\text { parágrafos que o antecedem, razão } \\
\text { pela qual não pode ser reconhecida a } \\
\text { prescrição intercorrente, nas hipóteses } \\
\text { em que o arquivamento do feito } \\
\text { ocorrer em razão do baixo valor do } \\
\text { débito executado (art. } 20 \text { da Lei } n^{\circ} \\
10.522 / 02) .\end{array}$ & $\begin{array}{l}\text { Ainda que a execução fiscal tenha } \\
\text { sido arquivada em razão do pequeno } \\
\text { valor do débito executado, sem baixa } \\
\text { na distribuição, nos termos do art. } 20 \\
\text { da Lei } 10.522 / 2002 \text {, deve ser } \\
\text { reconhecida a prescrição intercorrente } \\
\text { se o processo ficar paralisado por } \\
\text { mais de cinco anos a contar da } \\
\text { decisão que determina o } \\
\text { arquivamento, pois essa norma não } \\
\text { constitui causa de suspensão do prazo } \\
\text { prescricional. }\end{array}$ & REsp 1102554/MG & $27 / 05 / 2009$ \\
\hline 101 & $\begin{array}{l}\text { Questão referente à aplicação do } \\
\text { instituto da denúncia espontânea (art. } \\
138 \text { do CTN) aos casos de } \\
\text { parcelamento de débito tributário. }\end{array}$ & $\begin{array}{l}\text { O instituto da denúncia espontânea } \\
\text { (art. } 138 \text { do CTN) não se aplica nos } \\
\text { casos de parcelamento de débito } \\
\text { tributário. }\end{array}$ & REsp 1102577/DF & $22 / 04 / 2009$ \\
\hline 102 & $\begin{array}{l}\text { Questiona-se o cabimento da citação } \\
\text { editalícia na execução fiscal. }\end{array}$ & $\begin{array}{l}\text { A citação por edital na execução } \\
\text { fiscal é cabível quando frustradas as } \\
\text { demais modalidades. }\end{array}$ & REsp 1103050/BA & $25 / 03 / 2009$ \\
\hline 103 & $\begin{array}{l}\text { Discute-se a responsabilidade do } \\
\text { sócio-gerente, cujo nome consta da } \\
\text { CDA, para responder por débitos da } \\
\text { pessoa jurídica. }\end{array}$ & $\begin{array}{l}\text { Se a execução foi ajuizada apenas } \\
\text { contra a pessoa jurídica, mas o nome } \\
\text { do sócio consta da CDA, a ele } \\
\text { incumbe o ônus da prova de que não } \\
\text { ficou caracterizada nenhuma das } \\
\text { circunstâncias previstas no art. } 135 \text { do } \\
\text { CTN, ou seja, não houve a prática de } \\
\text { atos 'com excesso de poderes ou } \\
\text { infração de lei, contrato social ou } \\
\text { estatutos'. }\end{array}$ & REsp 1104900/ES & $25 / 03 / 2009$ \\
\hline 104 & $\begin{array}{l}\text { Discute-se a responsabilidade do } \\
\text { sócio-gerente, cujo nome consta da } \\
\text { CDA, para responder por débitos da } \\
\text { pessoa jurídica. }\end{array}$ & $\begin{array}{l}\text { A exceção de pré-executividade é } \\
\text { admissível na execução fiscal } \\
\text { relativamente às matérias conhecíveis } \\
\text { de ofício que não demandem dilação } \\
\text { probatória. }\end{array}$ & REsp 1104900/ES & $25 / 03 / 2009$ \\
\hline
\end{tabular}


105 Questiona-se se há decadência do direito de punir quando não expedida a notificação do infrator de trânsito no prazo de trinta dias, com a impossibilidade de reinício do procedimento administrativo.
107 Questão referente à aplicação do encargo de $20 \%$ previsto no Decretolei n. 1.025/69 nas execuções fiscais manejadas contra massa falida.

108 Estabelecer se é cabível a exceção de pré-executividade para argüição de ilegitimidade passiva, em execução fiscal proposta contra os sócios da pessoa jurídica devedora.

109 Prazo prescricional para pleitear os juros progressivos sobre saldos de conta vinculada do FGTS.

110 Prazo prescricional para pleitear parcelas decorrentes da opção pelo FGTS (Lei 5.958/73).

111 Discute-se o direito à taxa progressiva de juros para os optantes pelo FGTS (Lei 5.107/1966).

112 Discute-se a aplicação da taxa SELIC para apuração de correção monetária e juros nas ações para pleitear juros progressivos nas contas vinculadas do FGTS.

113 Termo inicial dos juros de mora em ações ajuizadas para pleitear juros juros progressivos sobre saldos de conta vinculada de FGTS.

114 Questiona-se se o executado é parte ilegítima para pleitear a redução da alíquota, além de negar a existência de denúncia espontânea, em caso de cobrança da majoração da alíquota do ICMS de $17 \%$ para $18 \%$ no Estado de São Paulo.

115 Questão referente à necessidade da juntada dos comprovantes de pagamento da taxa de iluminação pública juntamente com a petição inicial da ação de repetição de indébito tributário.
O art. 281, parágrafo único, II, do

CTB prevê que será arquivado o auto de infração e julgado insubsistente $o$ respectivo registro se não for expedida a notificação da autuação dentro de 30 dias. Por isso, não havendo a notificação do infrator para defesa no prazo de trinta dias, operase a decadência do direito de punir do Estado, não havendo que se falar em reinício do procedimento administrativo.

O encargo de $20 \%$ previsto no DL $\mathrm{n}$. 1.025/1969 é exigível na execução fiscal proposta contra a massa falida.

Não cabe exceção de pré-

executividade em execução fiscal promovida contra sócio que figura como responsável na Certidão de Dívida Ativa - CDA.

A prescrição da ação para pleitear os juros progressivos sobre os saldos de conta vinculada do FGTS não atinge o fundo de direito, limitando-se às parcelas vencidas.

\begin{tabular}{|l|l|l} 
Não estão prescritas as parcelas & REsp 1110547/PE & 22/04/2009
\end{tabular}
anteriores aos trinta anos que antecederam a propositura da ação.

\begin{tabular}{|l|l|l} 
Os optantes pelo FGTS, nos termos da & REsp 1110547/PE & 22/04/2009
\end{tabular} Lei $\mathrm{n}^{\circ} 5.958$, de 1973 , têm direito à taxa progressiva de juros na forma do art. $4^{\circ}$ da Lei ${ }^{\circ} 5.107 / 66$.

A taxa de juros moratórios a que se refere o art. 406 do CC/2002 é a taxa referencial do Sistema Especial de Liquidação e Custódia - SELIC.

\begin{tabular}{|l|l|l|}
\hline Incidem juros de mora pela taxa Selic & REsp 1110547/PE & 22/04/2009
\end{tabular} a partir da citação.

O art. 166 do CTN tem como cenário natural de aplicação as hipóteses em que o contribuinte de direito demanda a repetição do indébito ou a compensação de tributo cujo valor foi suportado pelo contribuinte de fato.

Mostra-se suficiente para autorizar o pleito repetitório a juntada de apenas um comprovante de pagamento da taxa de iluminação pública, pois isso demonstra que era suportada pelo contribuinte uma exação que veio a ser declarada inconstitucional. A definição dos valores exatos objeto de devolução será feita por liquidação de sentença, na qual obrigatoriamente deverá ocorrer a demonstração do quantum recolhido indevidamente.

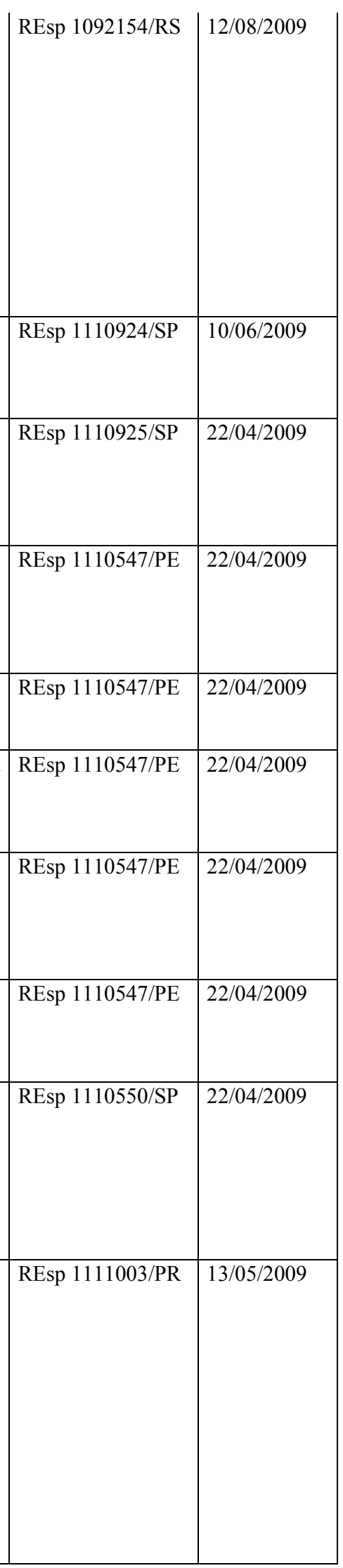


116 Questão referente à notificação do contribuinte acerca do lançamento do IPTU que pode dar-se por quaisquer atos administrativos eficazes de comunicação, cabendo-lhe comprovar que não possuía ciência quanto ao lançamento do imposto pelo Município.

117 Questão referente à inaplicabilidade do art. 29-C da Lei 8.036/90, à execução de valores correspondentes a honorários advocatícios.

118 Questão referente à compensação de créditos provenientes do pagamento indevido de contribuição ao PIS e ao FINSOCIAL com parcelas vencidas e vincendas dos mesmos tributos.

119 Questiona-se o índice dos juros moratórios em demanda objetivando a restituição de contribuição previdenciária de servidor público inativo.
120 Questiona-se a inadmissibilidade da substituição de penhora já realizada por precatórios emitidos pela Fazenda do Estado exequente.

121 Estabelecer se incide imposto de renda sobre férias proporcionais indenizadas e o respectivo adicional.

122 Questão referente à possibilidade de responsabilização do promitente vendedor e/ou do promitente comprador pelo pagamento do IPTU na execução fiscal, diante da existência de negócio jurídico que visa à transmissão da propriedade (contrato de compromisso de compra e venda).

123 Discute se é legítima a exigência do pagamento de multa e demais despesas decorrentes do recolhimento do veículo em depósito quando válida e eficaz a autuação da infração de trânsito.

124 Discute se é legítima a exigência do pagamento de multa e demais despesas decorrentes do recolhimento do veículo em depósito quando válida e eficaz a autuação da infração de trânsito.

125 Possibilidade de extinção de ofício de execução fiscal por carência de ação (interesse de agir) quando o valor excutido não superar o valor de alçada previsto no art. 20 da Lei 10.522/2002.
A remessa do carnê de pagamento do IPTU ao endereço do contribuinte é ato suficiente para a notificação do lançamento tributário.

O art. 29-C da Lei 8.036/90, introduzido pela Medida Provisória 2.164-40/2001 (dispensando a condenação em honorários em demandas sobre FGTS), é norma especial em relação aos arts. 20 e 21 do $\mathrm{CPC}$ e somente se aplica às ações ajuizadas após a sua vigência, que se deu em 27.07.2001.

É necessária a efetiva comprovação do recolhimento feito a maior ou indevidamente para fins de declaração do direito à compensação tributária em sede de mandado de segurança. Incide a taxa SELIC na repetição de indébito de tributos estaduais a partir da data de vigência da lei estadual que prevê a incidência de tal encargo sobre o pagamento atrasado de seus tributos e, relativamente ao período anterior, incide a taxa de $1 \%$ ao mês, nos termos do art. 161, $\S 1^{\circ}$, do CTN, observado o disposto na súmula 188/STJ, sendo inaplicável o art. $1^{\circ}-\mathrm{F}$ da Lei 9.494/97.

\section{A Fazenda Pública pode recusar a} substituição do bem penhorado por precatório.

São isentas de imposto de renda as indenizações de férias proporcionais e respectivo adicional.

1-Tanto o promitente comprador (possuidor a qualquer título) do imóvel quanto seu

proprietário/promitente vendedor (aquele que tem a propriedade registrada no Registro de Imóveis) são contribuintes responsáveis pelo pagamento do IPTU; 2-cabe à legislação municipal estabelecer o sujeito passivo do IPTU.

É lícito à autoridade administrativa condicionar a liberação de veículo, quando aplicada a pena de apreensão, ao pagamento das multas regularmente notificadas e já vencidas.

É legal a exigência de prévio pagamento das despesas com remoção e estada no depósito para liberação de veículo apreendido, sendo que as taxas de estada somente poderão ser cobradas até os 30 primeiros dias.

As execuções fiscais relativas a débitos iguais ou inferiores a $\mathrm{R} \$$ $10.000,00$ (dez mil reais) devem ter seus autos arquivados, sem baixa na distribuição.

\begin{tabular}{|l|l|}
\hline REsp 1111124/PR & $22 / 04 / 2009$ \\
\hline REsp 1111157/PB & $22 / 04 / 2009$ \\
\hline REsp 1111164/BA & $13 / 05 / 2009$ \\
\hline REsp 1111189/SP & $13 / 05 / 2009$ \\
\hline REsp 1104775/RS & $24 / 06 / 2009$ \\
\hline REsp 1104775/RS & \\
\hline & \\
\hline & \\
\hline & \\
\hline & \\
\hline & \\
\hline & \\
\hline & \\
\hline & \\
\hline
\end{tabular}


126 Questão referente à ação de desapropriação por utilidade pública, em que o acórdão recorrido decidiu que os juros compensatórios correspondem a $6 \%$ ao ano a partir da imissão na posse do imóvel.

127 Questão referente à obrigação da Caixa Econômica Federal em apresentar em juízo os extratos analíticos das contas do FGTS anteriores à centralização, para fins de atualização dos saldos.

128 Discute-se a possibilidade de condenar a municipalidade em honorários advocatícios quando a parte, representada por defensor público, restar vencedora na demanda. $\mathrm{O}$ julgado recorrido afastou a ondenação por reconhecer a existência de confusão entre credor e devedor.

129 Discute-se a possibilidade de condenar a municipalidade em honorários advocatícios quando a parte, restar vencedora na demanda. $\mathrm{O}$ julgado recorrido afastou a condenação por reconhecer a existência de confusão entre credor e devedor.

130 Possibilidade de prosseguimento de valores referentes ao pagamento de contribuição previdenciária estadual a pensionistas e servidores inativos diante da determinação do STF de suspensão cautelar da norma estadual que estabelece seu pagamento. representada por defensor público, ações ajuizadas para repetição de

Nas ações de desapropriação, os juros

compensatórios incidentes após a

Medida Provisória n. 1.577, de

$11 / 06 / 1997$, devem ser fixados em $6 \%$ ao ano até 13/09/2001 e, a partir de então, em $12 \%$ ao ano, na forma da Súmula n. 618 do Supremo Tribunal Federal.

A responsabilidade pela apresentação dos extratos analíticos das contas vinculadas do FGTS é exclusiva da Caixa Econômica Federal, inclusive com relação aos extratos anteriores à migração das contas que não tenham sido transferidas à CEF.

Os honorários advocatícios não são devidos à Defensoria Pública quando ela atua contra a pessoa jurídica de direito público à qual pertença.

Reconhece-se à Defensoria Pública o direito ao recebimento dos honorários advocatícios se a atuação se dá em face de ente federativo diverso do qual é parte integrante.

O Supremo Tribunal Federal deferiu medida cautelar na ADI n ${ }^{\circ}$ 2.189-3 para suspender as normas contidas na Lei Estadual no 12.398/98, que dispõe sobre as contribuições dos inativos e pensionistas para o fundo de previdência dos servidores públicos do Estado do Paraná, sem, no entanto, atribuir-lhe efeito retroativo. A cautela assim deferida não impede $o$ prosseguimento dos processos visando justamente afastar a aplicação da lei ou do ato normativo suspenso em decisão provida de eficácia erga omnes, tampouco o ajuizamento de novas ações que tenham por fundamento a restituição dos valores cobrados em virtude da norma excluída do mundo jurídico, ainda que em caráter precário.

131 Questão referente ao termo inicial do prazo para oferecimento dos embargos à execução fiscal, quando a garantia consiste na penhora de bens ou de direitos.

132 Questão referente à possibilidade de utilização de interpretação extensiva dos serviços bancários constantes da Lista Anexa à Lei Complementar 116/2003 e, para os fatos jurídicos que lhe são pretéritos, da Lista Anexa ao Decreto-lei 406/68.

\section{O termo inicial para a oposição dos} Embargos à Execução Fiscal é a data da efetiva intimação da penhora, e não a da juntada aos autos do mandado cumprido.

É legítima a incidência de ISS sobre os serviços bancários congêneres da lista anexa ao DL n. 406/1968 e à LC n. $56 / 1987$.
| REsp 1111829/SP | 13/05/2009

\begin{tabular}{l|l} 
REsp 1108013/RJ & 03/06/2009
\end{tabular}
e

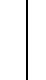


133 Questão referente à ausência de declaração de autenticidade das cópias pelo advogado.

134 Questão referente às providências indicadas no $\S 4^{\circ}$ do art. 40 da Lei $6.830 / 80$ que somente se aplicam em caso de prescrição intercorrente, razão pela qual se revela possível a decretação de ofício da prescrição verificada antes do ajuizamento, com base no $\S 5^{\circ}$ do art. 219 do CPC.

135 Questão referente ao prazo prescricional aplicável quando o crédito fiscal for decorrente de multa administrativa.

136 Questiona-se se é cabível o agravo de instrumento contra decisão concessiva ou denegatória de liminar em sede de mandado de segurança.

139 Questão referente à aplicação por analogia do enunciado da Súmula 215 do STJ para abarcar também as hipóteses de indenizações pagas por liberalidade ao empregado, já que estas não possuem natureza indenizatória.

140 Questão referente à possibilidade de comprovação, por outros meios idôneos, da existência de acordo celebrado entre o FGTS, com intervenção da Caixa Econômica Federal - agente operador, e o titular de conta vinculada, para reaver expurgos inflacionários ocorridos entre dezembro de 1988 e fevereiro de $1989(16,64 \%)$ e abril de 1990 $(44,08 \%)$.

141 Questão referente à movimentação de valores depositados em conta do FGTS e devolvidos ao Município pela $\mathrm{CEF}$, em virtude de contrato de trabalho declarado nulo por ausência de concurso público.
A autenticação de cópias do Agravo de Instrumento do artigo 522, do $\mathrm{CPC}$, resulta como diligência não prevista em lei, em face do acesso imediato aos autos principais, propiciado na instância local. A referida providência somente se impõe diante da impugnação específica da parte adversa. Em execução fiscal, a prescrição ocorrida antes da propositura da ação pode ser decretada de ofício (art. 219, $\S 5^{\circ}$, do CPC).

É de cinco anos o prazo prescricional para o ajuizamento da execução fiscal de cobrança de multa de natureza administrativa, contado do momento em que se torna exigível o crédito, com o vencimento do prazo do seu pagamento.

É cabível a interposição de agravo de instrumento contra decisão de magistrado de primeira instância que indefere ou concede liminar em mandado de segurança.

As verbas concedidas ao empregado por mera liberalidade do empregador, isto é, verba paga na ocasião da rescisão unilateral do contrato de trabalho sem obrigatoriedade expressa em lei, convenção ou acordo coletivo, implicam acréscimo patrimonial por não possuírem caráter indenizatório, sujeitando-se, assim, à incidência do imposto de renda.

É imprescindível para a validade da extinção do processo em que se discute complementação de correção monetária nas contas vinculadas de FGTS a juntada do termo de adesão devidamente assinado pelo titular da conta vinculada.

O titular da conta vinculada ao FGTS tem o direito de sacar o saldo respectivo quando declarado nulo seu contrato de trabalho por ausência de prévia aprovação em concurso público.

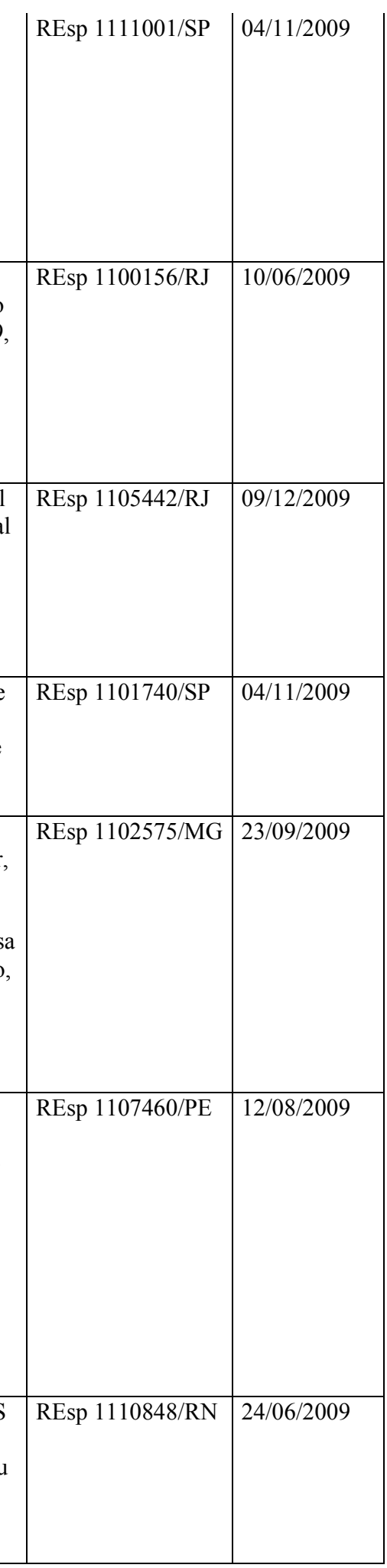




\begin{tabular}{|c|c|c|c|c|}
\hline 142 & $\begin{array}{l}\text { Questão referente ao termo inicial do } \\
\text { prazo prescricional para ajuizamento } \\
\text { de ação de repetição de tributo } \\
\text { instituído por norma legal declarada } \\
\text { inconstitucional pelo STF. }\end{array}$ & $\begin{array}{l}\text { O prazo de prescrição quinquenal para } \\
\text { pleitear a repetição tributária, nos } \\
\text { tributos sujeitos ao lançamento de } \\
\text { ofício, é contado da data em que se } \\
\text { considera extinto o crédito tributário, } \\
\text { qual seja, a data do efetivo pagamento } \\
\text { do tributo. A declaração de } \\
\text { inconstitucionalidade da lei } \\
\text { instituidora do tributo em controle } \\
\text { concentrado, pelo STF, ou a } \\
\text { Resolução do Senado (declaração de } \\
\text { inconstitucionalidade em controle } \\
\text { difuso) é despicienda para fins de } \\
\text { contagem do prazo prescricional tanto } \\
\text { em relação aos tributos sujeitos ao } \\
\text { lançamento por homologação, quanto } \\
\text { em relação aos tributos sujeitos ao } \\
\text { lançamento de ofício. }\end{array}$ & REsp 1110578/SP & $12 / 05 / 2010$ \\
\hline 143 & $\begin{array}{l}\text { Questão referente à contrariedade aos } \\
\text { artigos 535, I e II, do CPC, por } \\
\text { entender não ter sido apurada a culpa } \\
\text { do insucesso da execução fiscal; art. } \\
\text { 26, da Lei n. } 6.830 / 80 \text {, que prevê a } \\
\text { extinção da execução antes da decisão } \\
\text { de primeira instância sem qualquer } \\
\text { ônus para as partes; e art. } 1^{\circ} \text {-D, da Lei } \\
\text { n. } 9.494 / 97 \text {, que considera indevidos } \\
\text { os honorários advocatícios pela } \\
\text { Fazenda Pública também nas } \\
\text { execuções fiscais não embargadas. } \\
\text { Considera inaplicável ao caso a } \\
\text { Súmula n. 153, do STJ. } \\
\end{array}$ & $\begin{array}{l}\text { Em casos de extinção de execução } \\
\text { fiscal em virtude de cancelamento de } \\
\text { débito pela exequente, define a } \\
\text { necessidade de se perquirir quem deu } \\
\text { causa à demanda a fim de imputar-lhe } \\
\text { o ônus pelo pagamento dos honorários } \\
\text { advocatícios. }\end{array}$ & REsp 1111002/SP & $23 / 09 / 2009$ \\
\hline 144 & $\begin{array}{l}\text { Questão referente à incidência do } \\
\text { ICMS sobre produtos dados em } \\
\text { bonificação. }\end{array}$ & $\begin{array}{l}\text { Os descontos incondicionais nas } \\
\text { operações mercantis não se incluem } \\
\text { na base de cálculo do ICMS. }\end{array}$ & REsp 1111156/SP & $14 / 10 / 2009$ \\
\hline 145 & $\begin{array}{l}\text { Questão referente aos períodos de } \\
\text { aplicação da Taxa Selic nos juros de } \\
\text { mora incidentes sobre a repetição de } \\
\text { indébito tributário. }\end{array}$ & $\begin{array}{l}\text { Aplica-se a taxa SELIC, a partir de } \\
1^{\circ} .1 .1996, \text { na atualização monetária } \\
\text { do indébito tributário, não podendo } \\
\text { ser cumulada, porém, com qualquer } \\
\text { outro índice, seja de juros ou } \\
\text { atualização monetária. Se os } \\
\text { pagamentos foram efetuados após } \\
1^{\circ} .1 .1996, \text { o termo inicial para a } \\
\text { incidência do acréscimo será o do } \\
\text { pagamento indevido; havendo } \\
\text { pagamentos indevidos anteriores à } \\
\text { data de vigência da Lei } 9.250 / 95, \text { a } \\
\text { incidência da taxa SELIC terá como } \\
\text { termo a quo a data de vigência do } \\
\text { diploma legal em tela, ou seja, janeiro } \\
\text { de } 1996 .\end{array}$ & REsp 1111175/SP & $10 / 06 / 2009$ \\
\hline 146 & $\begin{array}{l}\text { Cinge-se a controvérsia sobre o prazo } \\
\text { prescricional para cobrança de multa } \\
\text { por infração à legislação ambiental. }\end{array}$ & $\begin{array}{l}\text { É de cinco anos o prazo para a } \\
\text { cobrança da multa aplicada ante } \\
\text { infração administrativa ao meio } \\
\text { ambiente, nos termos do Decreto }{ }^{\circ} \\
20.910 / 32 \text {, o qual que deve ser } \\
\text { aplicado por isonomia, à falta de regra } \\
\text { específica para regular esse prazo } \\
\text { prescricional. }\end{array}$ & REsp 1112577/SP & $09 / 12 / 2009$ \\
\hline 147 & $\begin{array}{l}\text { Cinge-se a controvérsia sobre o prazo } \\
\text { prescricional para cobrança de multa } \\
\text { por infração à legislação ambiental. }\end{array}$ & $\begin{array}{l}\text { Em se tratando de multa } \\
\text { administrativa, a prescrição da ação } \\
\text { de cobrança somente tem início com o } \\
\text { vencimento do crédito sem } \\
\text { pagamento, quando se torna } \\
\text { inadimplente o administrado infrator. }\end{array}$ & REsp 1112577/SP & $09 / 12 / 2009$ \\
\hline
\end{tabular}


148 Questão referente à restrição do valor do benefício previdenciário de prestação continuada ao limite máximo do salário-de-benefício na data de início do benefício.

149 Questão referente à possibilidade de imposição de multa diária prevista no art. 461 do CPC, pelo nãocumprimento da obrigação de fazer, qual seja, correção de contas vinculadas do FGTS.

150 Discute que as verbas recebidas a título de "compensação espontânea" e "gratificação não habitual", independentemente no nome que possuem, são decorrentes de Programa de Demissão Voluntária - PDV, havendo que ser aplicado o enunciado da Súmula 215 do STJ, que reconhece a não incidência do imposto de renda nessas hipóteses.

151 Discute que as verbas recebidas a título de "compensação espontânea" e "gratificação não habitual", independentemente no nome que possuem, são decorrentes de Programa de Demissão Voluntária - PDV, havendo que ser aplicado o enunciado da Súmula 215 do STJ, que reconhece a não incidência do imposto de renda nessas hipóteses.

152 Questão referente aos maiores índices expurgados do FGTS para fins de apuração de sucumbência.

53 Questão referente ao reconhecimento da inexigibilidade da tarifa cobrada pelo fornecimento de água $\mathrm{e}$ tratamento de esgoto, em que o Tribunal de origem decidiu que (a) é legítima a cobrança progressiva da tarifa de água e (b) a prescrição aplicável ao caso é qüinqüenal, nos termos do art. 27 do Código de Defesa do Consumidor.

154 Questão referente ao reconhecimento da inexigibilidade da tarifa cobrada pelo fornecimento de água $\mathrm{e}$ tratamento de esgoto, em que o Tribunal de origem decidiu que (a) é legítima a cobrança progressiva da tarifa de água e (b) a prescrição aplicável ao caso é qüinqüenal, nos termos do art. 27 do Código de Defesa do Consumidor.
O Plano de Benefícios da Previdência Social - PBPS, dando cumprimento ao art. 202, caput, da Constituição Federal (redação original), definiu o valor mínimo do salário-de-benefício, nunca inferior ao salário mínimo, e seu limite máximo, nunca superior ao limite máximo do salário-decontribuição.

É cabível a fixação de multa - de forma proporcional e razoável - pelo descumprimento de obrigação de fazer (astreintes), nos termos do art. $461, \S 4^{\circ}$, do CPC, no caso de atraso injustificado no fornecimento em juízo dos extratos de contas vinculadas ao FGTS.

As verbas concedidas ao empregado, por mera liberalidade do empregador, quando da rescisão unilateral de seu contrato de trabalho sujeitam-se à incidência do Imposto de Renda.

A indenização recebida pela adesão a programa de incentivo à demissão voluntária não está sujeita à incidência do imposto de renda.

REsp 1112574/MG | 26/08/2009

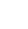

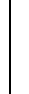

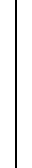


155 Questão referente ao reconhecimento da inexigibilidade da tarifa cobrada pelo fornecimento de água e tratamento de esgoto, em que o Tribunal de origem decidiu que (a) é legítima a cobrança progressiva da tarifa de água e (b) a prescrição aplicável ao caso é qüinqüenal, nos termos do art. 27 do Código de Defesa do Consumidor.

156 Questão referente à alegação de impossibilidade de condicionamento da concessão do benefício acidentário à irreversibilidade da moléstia incapacitante.

157 Discute-se a aplicação do princípio da insignificância, tendo em vista o valor dos tributos devidos, nos termos da Lei $n^{\circ} 10.522 / 02$.

158 Questão referente à averiguação da incidência do imposto de renda sobre os valores recebidos a título de antecipação ("Renda antecipada") de $10 \%$ da "Reserva Matemática" de Fundo de previdência privada, como incentivo para a migração para novo plano de benefícios da entidade.
A ação de repetição de indébito de tarifas de água e esgoto sujeita-se ao prazo prescricional estabelecido no Código Civil.

\begin{tabular}{|c|c|c|}
\hline $\begin{array}{l}\text { Será devido o auxílio-acidente quando } \\
\text { demonstrado o nexo de causalidade } \\
\text { entre a redução de natureza } \\
\text { permanente da capacidade laborativa } \\
\text { e a atividade profissional } \\
\text { desenvolvida, sendo irrelevante a } \\
\text { possibilidade de reversibilidade da } \\
\text { doenca. }\end{array}$ & REsp 1112886/SP & $25 / 11 / 2009$ \\
\hline
\end{tabular}
doença. 政 da insignificância aos débitos tributários que não ultrapassem o limite de R \$ 10.000,00 (dez mil reais), a teor do disposto no art. $20 \mathrm{da}$ Lei $n^{\circ} 10.522 / 02$.

Também com relação ao recebimento antecipado de $10 \%$ (dez por cento) da reserva matemática do Fundo de Previdência Privada como incentivo para a migração para novo plano de benefícios, deve-se afastar a incidência do imposto de renda sobre a parcela recebida a partir de janeiro de 1996, na proporção do que já foi anteriormente recolhido pelo contribuinte, a título de imposto de renda, sobre as contribuições vertidas ao fundo durante o período de vigência da Lei 7.713/88.

\begin{tabular}{|c|c|c|c|c|}
\hline 159 & $\begin{array}{l}\text { Questão referente à possibilidade de } \\
\text { compensação dos créditos de IPI } \\
\text { relativos à aquisição de matérias- } \\
\text { primas, insumos e produtos } \\
\text { intermediários tributados à alíquota } \\
\text { zero, nos moldes dos artigos } 11 \text { da Lei } \\
9.779 / 99 \text {. }\end{array}$ & $\begin{array}{l}\text { A ficção jurídica prevista no artigo } 11 \\
\text { da Lei } \text { n }^{\circ} 9.779 / 99 \text {, não alcança } \\
\text { situação reveladora de isenção do } \\
\text { Imposto sobre Produtos } \\
\text { Industrializados - IPI que a antecedeu. }\end{array}$ & REsp 860369/PE & $25 / 11 / 2009$ \\
\hline 160 & $\begin{array}{l}\text { Questão referente à inclusão do valor } \\
\text { do frete na base de cálculo do ICMS } \\
\text { nas vendas sujeitas à substituição } \\
\text { tributária (artigo } 13, \S 1^{\circ} \text {, II, "b", da } \\
\text { Lei Complementar } 87 / 96 \text { ). }\end{array}$ & $\begin{array}{l}\text { O valor do frete (referente ao } \\
\text { transporte do veículo entre a } \\
\text { montadora/fabricante e a } \\
\text { concessionária/revendedora) integra a } \\
\text { base de cálculo do ICMS incidente } \\
\text { sobre a circulação da mercadoria, para } \\
\text { fins da substituição tributária } \\
\text { progressiva ("para frente"), à luz do } \\
\text { artigo } 8^{\circ}, \text { II, "b", da Lei } \\
\text { Complementar 87/96. }\end{array}$ & REsp 931727/RS & $26 / 08 / 2009$ \\
\hline 161 & $\begin{array}{l}\text { Questão referente à inclusão do valor } \\
\text { do frete na base de cálculo do ICMS } \\
\text { nas vendas sujeitas à substituição } \\
\text { tributária (artigo } 13, \S 1^{\circ} \text {, II, "b", da } \\
\text { Lei Complementar } 87 / 96 \text { ). }\end{array}$ & $\begin{array}{l}\text { Nos casos em que a substituta } \\
\text { tributária (a montadora/fabricante de } \\
\text { veículos) não efetua o transporte, nem } \\
\text { o engendra por sua conta e ordem, o } \\
\text { valor do frete não deve ser incluído na } \\
\text { base de cálculo do imposto. }\end{array}$ & REsp 931727/RS & $26 / 08 / 2009$ \\
\hline
\end{tabular}

REsp 1112748/TO 09/09/2009

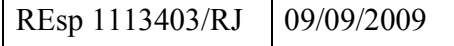

REsp 1111177/MG 23/09/2009 
162 Questão referente à legalidade da sistemática prevista nos artigos 29 e 36 da Lei 8.541/92, que determinam a incidência do imposto de renda na fonte, de forma autônoma e isolada, nas aplicações financeiras das pessoas jurídicas, inobstante a ocorrência de prejuízos.
163 Questão referente ao termo inicial do prazo decadencial para a constituição do crédito tributário pelo Fisco nas hipóteses em que o contribuinte não declara, nem efetua o pagamento antecipado do tributo sujeito a lançamento por homologação.

64 Questão referente à possibilidade de correção monetária de créditos operações de matérias-primas e insumos empregados na fabricação de produto isento ou beneficiado com alíquota zero. exigência de Certidão Negativa de Débito - CND, para o reconhecimento do benefício fiscal de drawback no "momento do desembaraço aduaneiro". escriturais de IPI referentes à

165 Questão referente à legalidade da

A tributação isolada e autônoma do imposto de renda sobre os

rendimentos auferidos pelas pessoas jurídicas em aplicações financeiras de renda fixa, bem como sobre os ganhos líquidos em operações realizadas nas bolsas de valores, de mercadorias, de futuros e assemelhadas, à luz dos artigos 29 e 36, da Lei 8.541/92, é legítima e complementar ao conceito de renda delineado no artigo 43 , do CTN, uma vez que as aludidas entradas financeiras não fazem parte da atividade-fim das empresas.

$O$ prazo decadencial quinquenal para o Fisco constituir o crédito tributário (lançamento de ofício) conta-se do primeiro dia do exercício seguinte àquele em que o lançamento poderia ter sido efetuado, nos casos em que a lei não prevê o pagamento antecipado da exação ou quando, a despeito da previsão legal, o mesmo inocorre, sem a constatação de dolo, fraude ou simulação do contribuinte, inexistindo declaração prévia do débito.

É devida a correção monetária sobre o valor referente a créditos de IPI admitidos extemporaneamente pelo Fisco.

É ilícita a exigência de nova certidão negativa de débito no momento do desembaraço aduaneiro da respectiva importação, se a comprovação de quitação de tributos federais já fora apresentada quando da concessão do benefício inerente às operações pelo regime de drawback.

166 Questão referente à possibilidade de substituição da CDA antes da sentença de mérito, na forma do disposto no $\S$ $8^{\circ}$, do artigo $2^{\circ}$, da Lei $6.830 / 80$, na hipótese de mudança de titularidade do imóvel sobre o qual incide o IPTU.

167 Questão referente à incidência do imposto de renda sobre as verbas pagas pela PETROBRÁS a título de "indenização por horas trabalhadas" IHT.

168 Questão referente à possibilidade de creditamento de IPI relativo à aquisição de materiais intermediários que se desgastam durante o processo produtivo sem contato físico ou químico direto com as matérias primas (bens destinados ao uso e consumo).

169 Questão referente à incidência do imposto de renda sobre verba paga a título de ajuda de custo pelo uso de veículo próprio no exercício das funções profissionais (auxíliocondução).
A Fazenda Pública pode substituir a certidão de dívida ativa (CDA) até a prolação da sentença de embargos, quando se tratar de correção de erro material ou formal, vedada a modificação do sujeito passivo da execução.

Incide imposto de renda sobre a verba intitulada 'Indenização por Horas Trabalhadas' - IHT, paga aos funcionários da Petrobrás, malgrado fundada em acordo coletivo.

A aquisição de bens integrantes do ativo permanente da empresa não gera direito a creditamento de IPI.

O auxílio condução consubstancia compensação pelo desgaste do patrimônio dos servidores, que utilizam-se de veículos próprios para o exercício da sua atividade profissional, inexistindo acréscimo patrimonial, mas uma mera

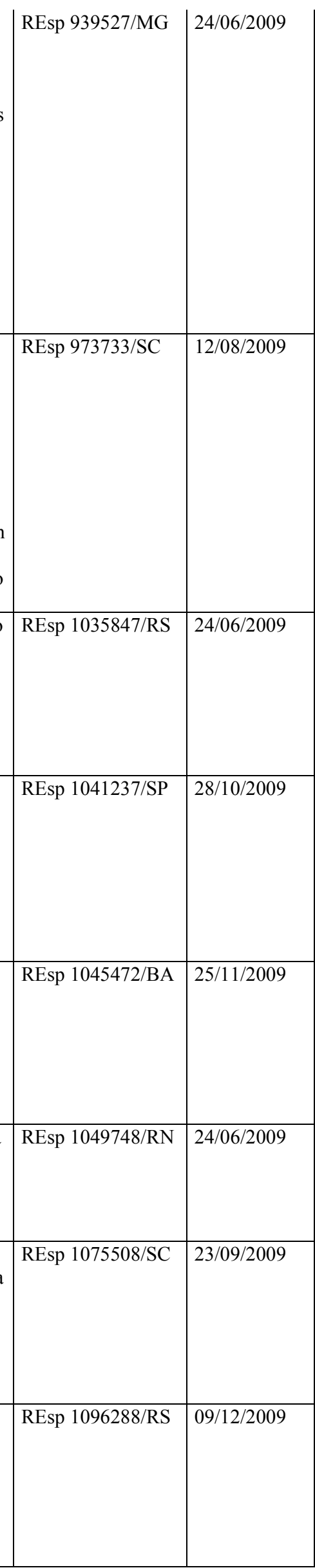




\begin{tabular}{|c|c|c|c|c|}
\hline & & $\begin{array}{l}\text { recomposição ao estado anterior sem } \\
\text { o incremento líquido necessário à } \\
\text { qualificação de renda. }\end{array}$ & & \\
\hline 170 & $\begin{array}{l}\text { Questão referente à possibilidade de } \\
\text { creditamento de ICMS incidente na } \\
\text { energia elétrica consumida em } \\
\text { estabelecimento comercial. }\end{array}$ & $\begin{array}{l}\text { Sob a égide do Convênio ICMS 66/88 } \\
\text { (antes, portanto, da entrada em vigor } \\
\text { da Lei Complementar 87/96) não } \\
\text { havia direito do contribuinte ao } \\
\text { crédito de ICMS recolhido quando } \\
\text { pago em razão de operações de } \\
\text { consumo de energia elétrica. } \\
\end{array}$ & REsp 977090/ES & $25 / 11 / 2009$ \\
\hline 171 & $\begin{array}{l}\text { Questão referente à aplicação às } \\
\text { empresas optantes pelo SIMPLES do } \\
\text { art. } 31 \text { da Lei } 8.212 / 91 \text {, segundo o } \\
\text { qual a empresa contratante de serviços } \\
\text { executados mediante cessão de mão de } \\
\text { obra, inclusive em regime de trabalho } \\
\text { temporário, deverá reter } 11 \% \text { (onze } \\
\text { por cento) do valor bruto da nota fiscal } \\
\text { ou fatura de prestação de serviços. }\end{array}$ & $\begin{array}{l}\text { A retenção da contribuição para a } \\
\text { seguridade social pelo tomador do } \\
\text { serviço não se aplica às empresas } \\
\text { optantes pelo Simples. }\end{array}$ & REsp 1112467/DF & $12 / 08 / 2009$ \\
\hline 172 & $\begin{array}{l}\text { Questão referente à fixação da } \\
\text { competência da justiça federal ou } \\
\text { estadual para apreciar demandas } \\
\text { referentes ao empréstimo compulsório } \\
\text { estabelecido em favor da eletrobrás, } \\
\text { nos casos em que a União manifesta } \\
\text { seu interesse no feito apenas após a } \\
\text { prolação da sentença. Para tanto, a } \\
\text { recorrente alega, além do dissídio } \\
\text { jurisprudencial, violação aos artigos } \\
\text { 50, e 535, I do CPC, bem como ao } \\
\text { artigo } 5^{\circ} \text { da Lei 9469/97. }\end{array}$ & $\begin{array}{l}\text { Demanda envolvendo questões } \\
\text { referentes ao empréstimo compulsório } \\
\text { sobre energia elétrica proposta } \\
\text { unicamente contra a Eletrobrás, } \\
\text { perante a justiça estadual. (...) O } \\
\text { pedido de intervenção da União } \\
\text { realizado após a prolação da sentença } \\
\text { enseja tão somente o deslocamento do } \\
\text { processo para o Tribunal Regional } \\
\text { Federal, para que examine o } \\
\text { requerimento de ingresso na lide e } \\
\text { prossiga (se for o caso) seu } \\
\text { julgamento, sem a automática } \\
\text { anulação da sentença proferida pelo } \\
\text { juízo estadual. }\end{array}$ & REsp 1111159/RJ & $11 / 11 / 2009$ \\
\hline 173 & $\begin{array}{l}\text { Questão referente à legitimidade ativa } \\
\text { ad causam do substituído (contribuinte } \\
\text { de fato) para pleitear a repetição de } \\
\text { indébito decorrente da incidência de } \\
\text { IPI (tributo indireto) sobre os } \\
\text { descontos incondicionais. }\end{array}$ & $\begin{array}{l}\text { O 'contribuinte de fato' (in casu, } \\
\text { distribuidora de bebida) não detém } \\
\text { legitimidade ativa ad causam para } \\
\text { pleitear a restituição do indébito } \\
\text { relativo ao IPI incidente sobre os } \\
\text { descontos incondicionais, recolhido } \\
\text { pelo 'contribuinte de direito' } \\
\text { (fabricante de bebida), por não } \\
\text { integrar a relação jurídica tributária } \\
\text { pertinente. }\end{array}$ & REsp 903394/AL & $24 / 03 / 2010$ \\
\hline 174 & $\begin{array}{l}\text { Questão referente à incidência de } \\
\text { IPTU sobre imóvel em que há } \\
\text { exploração de atividade agrícola, à luz } \\
\text { do Decreto-Lei 57/1966. }\end{array}$ & $\begin{array}{l}\text { Não incide IPTU, mas ITR, sobre } \\
\text { imóvel localizado na área urbana do } \\
\text { Município, desde que } \\
\text { comprovadamente utilizado em } \\
\text { exploração extrativa, vegetal, } \\
\text { agrícola, pecuária ou agroindustrial } \\
\text { (art. 15 do DL 57/1966). }\end{array}$ & REsp 1112646/SP & $26 / 08 / 2009$ \\
\hline 175 & $\begin{array}{l}\text { Questão referente ao cabimento de } \\
\text { embargos infringentes relativamente a } \\
\text { questões acessórias, a exemplo da } \\
\text { fixação de verbas honorárias, que } \\
\text { tenham sido decididas por maioria de } \\
\text { votos. Para tanto, alega-se violação ao } \\
\text { artigo } 530 \text { do CPC, bem como dissídio } \\
\text { jurisprudencial. }\end{array}$ & $\begin{array}{l}\text { Seja porque o art. } 530 \text { do CPC não faz } \\
\text { restrição quanto à natureza da matéria } \\
\text { objeto dos embargos infringentes - } \\
\text { apenas exige que a sentença de mérito } \\
\text { tenha sido reformada em grau de } \\
\text { apelação por maioria de votos -, seja } \\
\text { porque o capítulo da sentença que } \\
\text { trata dos honorários é de mérito, } \\
\text { embora acessório e dependente, } \\
\text { devem ser admitidos os embargos } \\
\text { infringentes para discutir verba de } \\
\text { sucumbência. }\end{array}$ & REsp 1113175/DF & $24 / 05 / 2012$ \\
\hline
\end{tabular}


176 Discute-se se há, ou não, violação à coisa julgada e à norma do art. 406 do novo Código Civil, quando o título judicial exequendo, exarado em momento anterior ao $\mathrm{CC} / 2002$, fixa os juros de mora em $0,5 \%$ ao mês e, na execução do julgado, determina-se a incidência de juros pela lei nova (CC de 2002).

178 Questão referente à aplicação dos expurgos inflacionários no cálculo da correção monetária dos saldos de conta vinculada do FGTS, reconhecendo que não restou configurado o excesso de execução, a partir da data em que deveriam ter sido pagas as diferenças cobradas.

179 Questão referente à alegada impossibilidade de decretação de prescrição intercorrente nos casos de demora na citação, por motivos inerentes ao mecanismo da justiça.

180 Questão referente à possibilidade de dedução do valor referente à CSLL da base de cálculo da própria contribuição para apuração do lucro real e do Imposto de Renda (discussão acerca das bases de cálculo do IRPJ e do CSLL, previstas nos artigos 43 do CTN, 47 da Lei $4.506 / 64$ e $1^{\circ}$ da Lei 9.316/96, além das Leis 6.404/76 e 7.689/88).

181 Questão referente à possibilidade de acumulação, por farmacêutico, de responsabilidade técnica por drogaria e farmácia, à luz do que dispõe o art. art. 20 da Lei 5.991/73 e art. 15 da Lei $5.991 / 73$.

182 Discussão acerca da exibilidade do depósito prévio para o conhecimento dos embargos apresentados pelo

183 Questão referente à incidência de ICMS sobre os encargos financeiros nas vendas a prazo.

184 Discute-se a fixação da verba honorária em $10 \%$ a recair sobre a diferença entre a oferta e o montante fixado a título de indenização. pois o valor devido deve ser atualizado curador especial.

Tendo sido a sentença exequenda prolatada anteriormente à entrada em vigor do Novo Código Civil, fixado juros de $6 \%$ ao ano, correto o entendimento do Tribunal de origem ao determinar a incidência de juros de 6\% ao ano até 11 de janeiro de 2003 e, a partir de então, da taxa a que alude o art. 406 do Novo CC, conclusão que não caracteriza qualquer violação à coisa julgada.

As diferenças de correção monetária resultantes de expurgos inflacionários sobre os saldos de FGTS têm como termo inicial a data em que deveriam ter sido creditadas.

A perda da pretensão executiva tributária pelo decurso de tempo é consequência da inércia do credor, que não se verifica quando a demora na citação do executado decorre unicamente do aparelho judiciário.

Inexiste qualquer

ilegalidade/inconstitucionalidade na determinação de indedutibilidade da CSSL na apuração do lucro real.

O farmacêutico pode acumular a responsabilidade técnica por unidade farmacêutica e por unidade de drogaria, bem como a responsabilidade por duas drogarias, espécies do gênero 'farmácia'. É dispensado o curador especial de oferecer garantia ao Juízo para opor embargos à execução.

O ICMS incide sobre o preço total da venda quando o acréscimo é cobrado pelo próprio vendedor (venda a prazo).

\begin{tabular}{|l|l|l}
\hline O valor dos honorários advocatícios & REsp 1114407/SP & 09/12/2009
\end{tabular} em sede de desapropriação deve respeitar os limites impostos pelo artigo 27, $\S 1^{\circ}$, do Decreto-lei $3.365 / 41$ - qual seja: entre $0,5 \%$ e $5 \%$ da diferença entre o valor proposto inicialmente pelo imóvel e a indenização imposta judicialmente.

185 BENEFÍCIO ASSISTENCIAL. POSSIBILIDADE DE DEMONSTRAÇÃO DA CONDIÇÃO DE MISERABILIDADE DO BENEFICIÁRIO POR OUTROS MEIOS DE PROVA, QUANDO A RENDA PER CAPITA DO NÚCLEO FAMILIAR FOR SUPERIOR A $1 / 4$ DO SALÁRIO MÍNIMO. \begin{tabular}{|l|l} 
REsp 1112743/BA & $12 / 08 / 2009$
\end{tabular}

REsp 1112413/AL $\quad$ 23/09/2009

REsp 1102431/RJ 09/12/2009

REsp 1112884/MG 26/08/2009

REsp 1106462/SP $23 / 09 / 2009$
REsp 1113159/AM 11/11/2009

A limitação do valor da renda per capita familiar não deve ser

considerada a única forma de se comprovar que a pessoa não possui outros meios para prover a própria manutenção ou de tê-la provida por sua família, pois é apenas um elemento objetivo para se aferir a necessidade, ou seja, presume-se

\begin{tabular}{|l|l|}
\hline REsp 1112557/MG & 28/10/2009 \\
& \\
&
\end{tabular}




\begin{tabular}{|c|c|c|c|c|}
\hline & & $\begin{array}{l}\text { absolutamente a miserabilidade } \\
\text { quando comprovada a renda per } \\
\text { capita inferior a } 1 / 4 \text { do salário } \\
\text { mínimo. }\end{array}$ & & \\
\hline 186 & $\begin{array}{l}\text { BENEFÍCIO CONCEDIDO ANTES } \\
\text { DA CONSTITUIÇÃO FEDERAL } \\
\text { VIGENTE. SALÂRIO-DE- } \\
\text { CONTRIBUIÇÃO. CORREÇÃO } \\
\text { MONETÁRIA. }\end{array}$ & $\begin{array}{l}\text { É incabível a correção monetária dos } \\
\text { salários de contribuição considerados } \\
\text { no cálculo do salário de benefício de } \\
\text { auxílio-doença, aposentadoria por } \\
\text { invalidez, pensão ou auxílio-reclusão } \\
\text { concedidos antes da vigência da } \\
\text { CF/1988. }\end{array}$ & REsp 1113983/RN & $28 / 04 / 2010$ \\
\hline 187 & $\begin{array}{l}\text { APOSENTADORIA POR } \\
\text { INVALIDEZ. BENEFÍCIO } \\
\text { CONCEDIDO ANTES DA } \\
\text { CONSTITUIÇÃO FEDERAL } \\
\text { VIGENTE. SALÁRIO-DE- } \\
\text { CONTRIBUIÇÃO. CORREÇÃO } \\
\text { MONETÁRIA. }\end{array}$ & $\begin{array}{l}\text { É incabível a correção monetária dos } \\
\text { salários de contribuição considerados } \\
\text { no cálculo do salário de benefício de } \\
\text { auxílio-doença, aposentadoria por } \\
\text { invalidez, pensão ou auxílio-reclusão } \\
\text { concedidos antes da vigência da } \\
\text { CF/1988. }\end{array}$ & REsp 1113983/RN & $28 / 04 / 2010$ \\
\hline 188 & $\begin{array}{l}\text { BENEFÍCIO CONCEDIDO ANTES } \\
\text { DA CONSTITUIÇÃO FEDERAL } \\
\text { VIGENTE. SALÂRIO-DE- } \\
\text { CONTRIBUIÇÃO. CORREÇÃO } \\
\text { MONETÁRIA. }\end{array}$ & $\begin{array}{l}\text { É incabível a correção monetária dos } \\
\text { salários de contribuição considerados } \\
\text { no cálculo do salário de benefício de } \\
\text { auxílio-doença, aposentadoria por } \\
\text { invalidez, pensão ou auxílio-reclusão } \\
\text { concedidos antes da vigência da } \\
\text { CF/1988. }\end{array}$ & REsp 1113983/RN & $28 / 04 / 2010$ \\
\hline 189 & $\begin{array}{l}\text { BENEFÍCIO CONCEDIDO ANTES } \\
\text { DA CONSTITUIÇÃO FEDERAL } \\
\text { VIGENTE. SALÁRIO-DE- } \\
\text { CONTRIBUIÇÃO. CORREÇÃO } \\
\text { MONETÁRIA. }\end{array}$ & $\begin{array}{l}\text { É incabível a correção monetária dos } \\
\text { salários de contribuição considerados } \\
\text { no cálculo do salário de benefício de } \\
\text { auxílio-doença, aposentadoria por } \\
\text { invalidez, pensão ou auxílio-reclusão } \\
\text { concedidos antes da vigência da } \\
\text { CF/1988. }\end{array}$ & REsp 1113983/RN & $28 / 04 / 2010$ \\
\hline 190 & $\begin{array}{l}\text { Questão referente à fixação da pena } \\
\text { abaixo do mínimo legal na segunda } \\
\text { fase da dosimetria, bem como a } \\
\text { determinação de que o percentual de } \\
\text { redução previsto no } \S 4^{\circ} \text { do art. } 33 \text { da } \\
\text { Lei n. } 11.343 / 2006 \text {, incida sobre o } \\
\text { caput do mesmo artigo, caso seja mais } \\
\text { benéfico ao paciente. }\end{array}$ & $\begin{array}{l}\text { O critério trifásico de } \\
\text { individualização da pena, trazido pelo } \\
\text { art. } 68 \text { do Código Penal, não permite } \\
\text { ao Magistrado extrapolar os marcos } \\
\text { mínimo e máximo abstratamente } \\
\text { cominados para a aplicação da sanção } \\
\text { penal. }\end{array}$ & REsp 1117068/PR & $26 / 10 / 2011$ \\
\hline 191 & $\begin{array}{l}\text { Questão referente à fixação da pena } \\
\text { abaixo do mínimo legal na segunda } \\
\text { fase da dosimetria, bem como a } \\
\text { determinação de que o percentual de } \\
\text { redução previsto no } \S 4^{\circ} \text { do art. } 33 \text { da } \\
\text { Lei n. } 11.343 / 2006 \text {, incida sobre o } \\
\text { caput do mesmo artigo, caso seja mais } \\
\text { benéfico ao paciente. }\end{array}$ & $\begin{array}{l}\text { É cabível a aplicação retroativa da Lei } \\
\text { n. } 11.343 / 2006 \text {, desde que o resultado } \\
\text { da incidência das suas disposições, na } \\
\text { íntegra, seja mais favorável ao réu do } \\
\text { que o advindo da utilização da Lei } \\
6.368 / 76 \text {, sendo vedada a combinação } \\
\text { de leis. }\end{array}$ & REsp 1117068/PR & $26 / 10 / 2011$ \\
\hline 192 & $\begin{array}{l}\text { Questão referente a não abrangência } \\
\text { na pensão alimentícia da gratificação } \\
\text { natalina e da gratificação de férias } \\
\text { recebidas pelo alimentante. }\end{array}$ & $\begin{array}{l}\text { A pensão alimentícia incide sobre o } \\
\text { décimo terceiro salário e o terço } \\
\text { constitucional de férias, também } \\
\text { conhecidos, respectivamente, por } \\
\text { gratificação natalina e gratificação de } \\
\text { férias. }\end{array}$ & REsp 1106654/RJ & $25 / 11 / 2009$ \\
\hline 193 & $\begin{array}{l}\text { Questão referente à legitimidade } \\
\text { passiva da União, em demandas } \\
\text { promovidas por servidores públicos } \\
\text { estaduais, objetivando a isenção ou } \\
\text { não-incidência de imposto de renda } \\
\text { retido na fonte, em que o produto da } \\
\text { arrecadação do tributo pertence aos } \\
\text { Estados da Federação. }\end{array}$ & $\begin{array}{l}\text { Os Estados da Federação são partes } \\
\text { legítimas para figurar no pólo passivo } \\
\text { das ações propostas por servidores } \\
\text { públicos estaduais, que visam o } \\
\text { reconhecimento do direito à isenção } \\
\text { ou à repetição do indébito relativo ao } \\
\text { imposto de renda retido na fonte. }\end{array}$ & REsp 989419/RS & $25 / 11 / 2009$ \\
\hline
\end{tabular}


194 Questão referente à impossibilidade de os embargos de declaração opostos contra decisão de órgão colegiado terem seu seguimento obstado monocraticamente, ex vi do artigo 537 do CPC.

195 Questão referente à possibilidade de compensação de honorários, nos termos do art. 21 do CPC, quando da ocorrência de sucumbência recíproca, sem implicar violação ao art. 23 da Lei 8.906/94 - Estatuto da Advocacia.

196 Questão referente à incidência de COFINS sobre as receitas auferidas com as operações de locação de bens móveis.

197 Questão referente à tese de que o termo inicial dos juros de mora, em ação a versar sobre o pagamento de indenização referente ao seguro DPVAT, é o da data da citação na ação de cobrança.

198 Questão central trata da competência tributária para a cobrança de ISS, quando da realização de serviço de engenharia consultiva. $\mathrm{O}$ acórdão impugnado firmou entendimento no sentido de que a competência tributária para a cobrança do sobredito imposto é do município onde se situa o estabelecimento do prestador.

199 Questão referente à utilização da taxa SELIC como índice de correção monetária e de juros de mora, na atualização dos débitos tributários pagos em atraso, diante da existência de Lei Estadual que determina a adoção dos mesmos critérios adotados na correção dos débitos fiscais federais.

200 Questão referente à nulidade do auto de infração, por considerar insubsistente multa fundada em Resolução do CONMETRO, com conteúdo material não previsto na norma regulamentada.

201 Questão referente à necessidade de publicação do editais nos moldes previstos no art. 605 da CLT para fins de cobrança da contribuição sindical rural.

Opostos embargos declaratórios de decisão colegiada, o relator poderá negar seguimento monocraticamente, com base no caput do artigo 557 do CPC.

Os honorários advocatícios devem ser
compensados quando houver sucumbência recíproca, assegurado o direito autônomo do advogado à execução do saldo sem excluir a legitimidade da própria parte.

A Contribuição para Financiamento da Seguridade Social - Cofins incide sobre as receitas provenientes das operações de locação de bens móveis.

\begin{tabular}{|l|l|l|l}
\hline Os juros de mora na indenização do & REsp 1098365/PR & 28/10/2009
\end{tabular}
seguro DPVAT fluem a partir da citação.

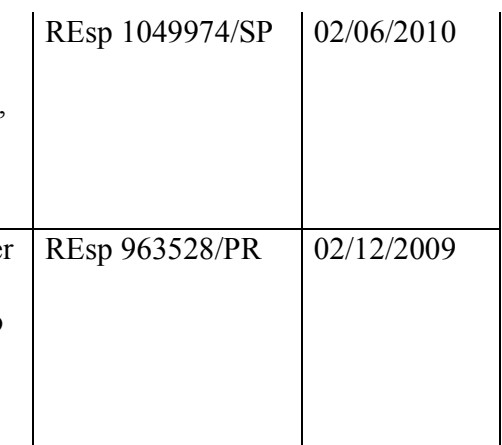

Em se tratando de construção civil, antes ou depois da lei complementar, o imposto é devido no local da construção (art. 12, letra "b" do DL $406 / 68$ e art. $3^{\circ}$, da LC $116 / 2003$ ).

A Taxa SELIC é legítima como índice de correção monetária e de juros de mora, na atualização dos débitos tributários pagos em atraso, diante da existência de Lei Estadual que determina a adoção dos mesmos critérios adotados na correção dos débitos fiscais.

Estão revestidas de legalidade as normas expedidas pelo CONMETRO e INMETRO, e suas respectivas infrações, com o objetivo de regulamentar a qualidade industrial e a conformidade de produtos colocados no mercado de consumo. Conforme o disposto no artigo $605 \mathrm{da}$ Consolidação da Leis do Trabalho, em respeito ao princípio da publicidade, a publicação, em jornais de grande circulação local, de editais concernentes ao recolhimento da contribuição sindical é condição necessária à eficácia do procedimento do recolhimento deste tributo, matéria que consubstancia pressuposto para o desenvolvimento regular do processo e pode ser apreciada de ofício pelo Juiz. 
203 Questão referente aos índices de reajuste das contas vinculadas ao FGTS (fev/89, jun/90, jul/90, jan/91 e $\operatorname{mar} / 91)$.

204 Discute-se a ilegitimidade passiva da Caixa Econômica Federal em ações ajuizada para requerer a aplicação dos índices de atualização monetária dos saldos das contas vinculadas ao FGTS

205 Discute-se a obrigatoriedade do litisconsórcio passivo necessário da União em ações ajuizada para requerer a aplicação dos índices de atualização monetária dos saldos das contas vinculadas ao FGTS.

206 Discute-se a obrigatoriedade de litisconsórcio passivo necessário dos bancos depositários em ações ajuizada para requerer a aplicação dos índices de atualização monetária dos saldos das contas vinculadas ao FGTS.

207 Discute-se o prazo prescrional para cobrança de correção monetária de contas vinculadas ao FGTS.

208 Estabelecer os índices aplicáveis para correção monetária de contas vinculadas ao FGTS nos meses de junho/1987, janeiro/1989, abril/1990, maio/1990, julho/1990, e fevereiro/1991.

209 Questão referente à legitimidade de ex-proprietário de imóvel rural para integrar o pólo passivo de execução fiscal, que visa a cobrança de créditos tributários relativos ao ITR, sendo certa a inexistência de registro no cartório competente a comprovar a translação do domínio.

210 Questão referente à ação de desapropriação por utilidade pública, em que o acórdão recorrido decidiu que (a) os juros moratórios são incidentes a partir do trânsito em julgado; (b) a cumulação dos juros compensatórios e moratórios não implica em anatocismo vedado pela Lei de Usura.
No tocante à correção monetária incidente no mês de fevereiro de 1989, o Superior Tribunal de Justiça firmou entendimento de que deve ser IPC, ou seja, no percentual de 10,14\%. [...] Em relação aos demais índices postulados, firmou-se a jurisprudência desta Corte no sentido de que a correção dos saldos deve ser de $9,61 \%$ em junho/90 (BTN), $10,79 \%$ em julho/90 (BTN), 13,69\% em janeiro/91 (IPC) e $8,5 \%$ em março/91 (TR).

Nas demandas que tratam da atualização monetária dos saldos das contas vinculadas do FGTS, a legitimidade passiva ad causam é exclusiva da Caixa Econômica Federal, por ser gestora do Fundo, com a exclusão da União e dos bancos depositários (Súmula 249/STJ).

Nas demandas que tratam da atualização monetária dos saldos das contas vinculadas do FGTS, a legitimidade passiva ad causam é Federal, por ser gestora do Fundo, com a exclusão da União e dos bancos depositários (Súmula 249/STJ). Nas demandas que tratam da atualização monetária dos saldos das contas vinculadas do FGTS, a legitimidade passiva ad causam é exclusiva da Caixa Econômica Federal, por ser gestora do Fundo, com a exclusão da União e dos bancos depositários (Súmula 249/STJ).

É trintenária a prescrição para cobrança de correção monetária de contas vinculadas ao FGTS, nos termos das Súmula 210/STJ.

Os acréscimos monetários nas contas vinculadas ao Fundo de Garantia do Tempo de Serviço, nos meses de junho/87, janeiro/89, abril e maio/90 e fevereiro/91 são, respectivamente, $18,02 \%$ (LBC), 42,72\%, 44,80\% (IPC), 5,38 (BTN) e 7\% (TR). Enunciado da Súmula 252/STJ.

O promitente vendedor é parte legítima para figurar no pólo passivo da execução fiscal que busca a cobrança de ITR nas hipóteses em que não há registro imobiliário do ato translativo de propriedade. em desapropriações é o dia $1^{\circ}$ de janeiro do exercício seguinte àquele em que o pagamento deveria ser feito. calculada com base na variação do exclusiva da Caixa Econômica

O termo inicial dos juros moratórios

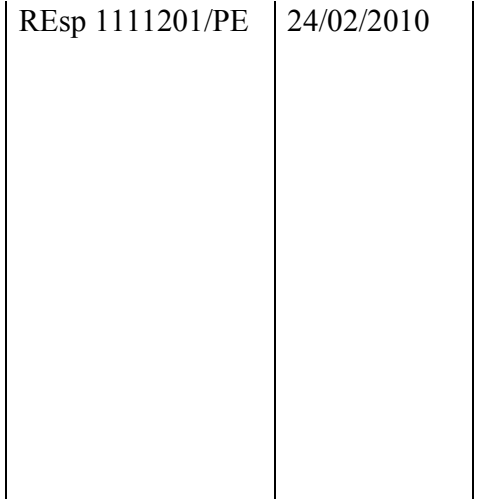

REsp 1112520/PE $24 / 02 / 2010$

$\begin{array}{ll}\text { REsp 1112520/PE } & \text { 24/02/2010 }\end{array}$

REsp 1112520/PE $24 / 02 / 2010$

REsp

$1112520 / \mathrm{PE}$ $24 / 02 / 2010$

\begin{tabular}{|l|l|}
\hline REsp 1112520/PE & 24/02/2010 \\
&
\end{tabular}

REsp 1112520/PE $24 / 02 / 2010$

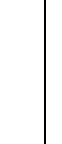


211 Questão referente à ação de desapropriação por utilidade pública, em que o acórdão recorrido decidiu que (a) os juros moratórios são incidentes a partir do trânsito em julgado; (b) a cumulação dos juros compensatórios e moratórios não implica em anatocismo vedado pela Lei de Usura.

212 Questão referente à pretensão executória concernente aos honorários advocatícios de valor abaixo do estipulado no art. $1^{\circ}$ da Lei ${ }^{\circ}$ 9.469/97, porque se configura a "ausência de interesse de agir" do autor "para a cobrança de verba honorária em valor ínfimo, que sequer cobriria as despesas com a execução".

213 AUXÍLIO-ACIDENTE. ART. 86 DA LEI 8.213/91. REQUISITO PARA A CONCESSÃO DO BENEFÍCIO. ALEGAÇÃO DE NECESSIDADE DE COMPROVAÇÃO DA EFETIVA REDUÇÃO DA CAPACIDADE LABORATIVA DO SEGURADO.

214 REVISÃO DA RENDA MENSAL INICIAL. INCIDÊNCIA DO PRAZO DE DECADÊNCIA INSTITUÍDO PELO ART. 103 DA LEI 8.213/91, COM A REDAÇÃO DADA PELA LEI 9.528/97, AOS BENEFÍCIOS CONCEDIDOS EM DATA ANTERIOR À SUA VIGÊNCIA.
Os juros compensatórios, em desapropriação, somente incidem até a data da expedição do precatório original (...), não havendo hipótese de cumulação de juros moratórios com juros compensatórios.

A extinção das ações de pequeno

valor é faculdade da Administração Federal, vedada a atuação judicial de ofício.
Para a concessão de auxílio-acidente

fundamentado na perda de audição

(...), é necessário que a sequela seja

ocasionada por acidente de trabalho e que acarrete uma diminuição efetiva e permanente da capacidade para a atividade que o segurado habitualmente exercia.

Os atos administrativos praticados antes da Lei 9.784/99 podem ser revistos pela Administração a qualquer tempo, por inexistir norma legal expressa prevendo prazo para tal iniciativa. Somente após a Lei 9.784/99 incide o prazo decadencial de 5 anos nela previsto, tendo como termo inicial a data de sua vigência (01.02.99). (...) Antes de decorridos 5 anos da Lei 9.784/99, a matéria passou a ser tratada no âmbito previdenciário pela MP 138, de 19.11.2003, convertida na Lei $10.839 / 2004$, que acrescentou o art. 103-A à Lei 8.213/91 (LBPS) e fixou em 10 anos o prazo decadencial para o INSS rever os seus atos de que decorram efeitos favoráveis a seus beneficiários.

215 Questão referente à forma de cálculo da contribuição previdenciária incidente sobre a gratificação natalina.

216 Questão referente à forma de cálculo da contribuição previdenciária incidente sobre a gratificação natalina.
Sob a égide da Lei n. ${ }^{\circ} 8.212 / 91$, é

ilegal o cálculo, em separado, da

contribuição previdenciária sobre a gratificação natalina em relação ao salário do mês de dezembro.

A Lei n. 8.620/93, em seu art. $7^{\circ}, \S$ 2. ${ }^{\circ}$ autorizou expressamente a incidência da contribuição previdenciária sobre o valor bruto do $13 .^{\circ}$ salário, cuja base de cálculo deve ser calculada em separado do saláriode-remuneração do respectivo mês de dezembro.

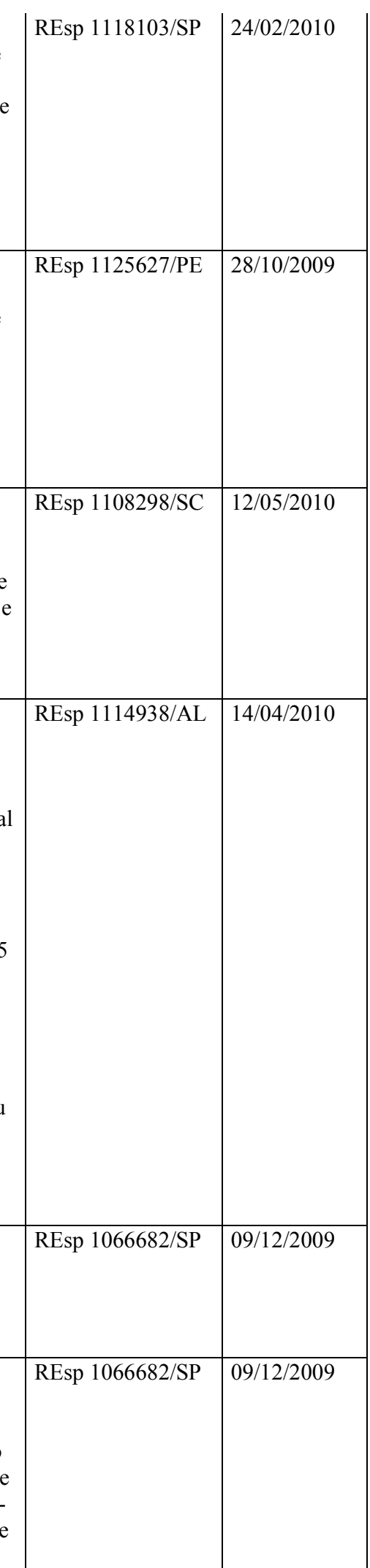


217 Questiona-se a forma de interpretação e o alcance da expressão serviços hospitalares, prevista no artigo $15, \S$ $1^{\circ}$, inciso III, alínea "a", da Lei 9.429/95, para fins de recolhimento do IRPJ e da CSLL com base em alíquotas reduzidas.
218 Questão referente à necessidade da comprovação do esgotamento das diligências para localização de bens de propriedade do devedor para a realização das providências previstas no art. 655-A do CPC.
219 Questão referente à necessidade da comprovação do esgotamento das diligências para localização de bens de propriedade do devedor para a realização das providências previstas no art. 655-A do CPC.

220 Questão referente à impossibilidade de decretação da prisão civil do depositário infiel.

221 Questiona-se se o crime de corrupção de menores afigura-se formal: é que o resultado ínsito ao art. 1o. da Lei 2.252/54 - a corrupção, a degradação moral do menor - evidencia-se da consumação ou mesmo da tentativa, do próprio ilícito perpetrado pelo agente ativo com a colaboração - de qualquer espécie - de pessoa com menos de 18 (dezoito) anos.

222 Questão referente à impossibilidade de ajuizamento de ação própria pelo advogado da parte cujo pedido foi julgado procedente, objetivando a fixação de honorários advocatícios, quando transitada em julgado decisão omissa na condenação em verba sucumbencial.

223 Questiona-se acerca da possibilidade da incidência da TR como índice de correção monetária e juros de mora aos débitos de FGTS não repassados ao fundo pelo empregador.
Para fins do pagamento dos tributos com as alíquotas reduzidas, a expressão 'serviços hospitalares', constante do artigo $15, \S 1^{\circ}$, inciso III, da Lei 9.249/95, deve ser interpretada de forma objetiva (ou seja, sob a perspectiva da atividade realizada pelo contribuinte), devendo ser considerados serviços hospitalares 'aqueles que se vinculam às atividades desenvolvidas pelos hospitais, voltados diretamente à promoção da saúde', de sorte que, 'em regra, mas não necessariamente, são prestados no interior do estabelecimento hospitalar, excluindo-se as simples consultas médicas, atividade que não se identifica com as prestadas no âmbito hospitalar, mas nos consultórios médicos'.

A penhora on line, antes da entrada em vigor da Lei n. 11.382/2006, configura-se como medida excepcional, cuja efetivação está condicionada à comprovação de que o credor tenha tomado todas as diligências no sentido de localizar bens livres e desembaraçados de titularidade do devedor.

Após o advento da Lei $\mathrm{n}$

11.382/2006, o Juiz, ao decidir acerca da realização da penhora on line, não pode mais exigir a prova, por parte do credor, de exaurimento de vias extrajudiciais na busca de bens a serem penhorados.

Descabe a prisão civil do depositário judicial infiel.

A configuração do crime do art. 244$\mathrm{B}$ do ECA independe da prova da efetiva corrupção do menor, por se tratar de delito formal.
| REsp 1116399/BA |28/10/2009 
224 Discute-se a possibilidade da incidência da TR como índice de correção monetária e juros de mora aos débitos de FGTS não repassados ao fundo pelo empregador. deferimento de modificações no CNPJ, para incluir, no quadro societário da empresa, pessoa física com pendências perante a Receita Federal, nos termos dos limites impostos pela IN SRF 200/02, que regulamentou, em parte, a Lei $n^{\circ}$ $5.614 / 70$.
O art. 22, § $1^{\circ}$, da Lei 8.036/90 diz respeito a correção monetária e juros de mora a que está sujeito o empregador quando não efetua os depósitos ao FGTS, verbis: Art. 22. O empregador que não realizar os depósitos previstos nesta Lei, no prazo fixado no art. 15, responderá pela incidência da Taxa Referencial TR sobre a importância correspondente. $\S 1^{\circ}$ Sobre o valor dos depósitos, acrescido da TR, incidirão, ainda, juros de mora de $0,5 \%$ a.m. (cinco décimos por cento ao mês) ou fração e multa, sujeitandose, também, às obrigações e sanções previstas no Decreto-Lei no 368, de 19 de dezembro de 1968. A inscrição e modificação dos dados no Cadastro Nacional de Pessoas Jurídicas - CNPJ devem ser garantidas a todas as empresas legalmente constituídas, mediante o arquivamento de seus estatutos e suas alterações na Junta Comercial Estadual, sem a imposição de restrições infralegais, que obstaculizem o exercício da livre iniciativa e desenvolvimento pleno de suas atividades econômicas. O crédito-prêmio do IPI, previsto no art. $1^{\circ}$ do DL $491 / 69$, não se aplica às vendas para o exterior realizadas após 04.10.90.

EXTINÇ̃̃O EM 1983, POR FORÇA DO DISPOSTO NO DECRETO-LEI $\mathrm{N}^{\circ} 1.658 / 79$, COM REDAÇÃO DADA PELO DECRETO-LEI N ${ }^{\circ}$ 1.722/79

227 Prazo prescricional nas demandas onde se discute a utilização do Crédito-Prêmio IPI.

228 Questona-se se é facultado ao contribuinte que detém crédito contra a Fazenda Pública por tributo indevidamente pago optar pela restituição via precatório ou compensação, conforme previsão legal do ente tributante.

229 Questão referente ao prazo prescricional quinquenal adotado em sede de ação declaratória de nulidade de lançamentos tributários (art. $1^{\circ}$ do Decreto 20.910/32).
O prazo prescricional das ações que visam ao recebimento do créditoprêmio do IPI, nos termos do art. $1^{\circ}$ do Decreto 20.910/32, é de cinco anos. \begin{tabular}{|l|l|l|l|}
\hline O contribuinte pode optar por receber, & REsp 1114404/MG & 10/02/2010
\end{tabular} por meio de precatório ou por compensação, o indébito tributário certificado por sentença declaratória transitada em julgado.

A ação de repetição de indébito (...)
visa à restituição de crédito tributário pago indevidamente ou a maior, por isso que o termo a quo é a data da extinção do crédito tributário, momento em que exsurge o direito de ação contra a Fazenda Pública, sendo certo que, por tratar-se de tributo sujeito ao lançamento de ofício, o prazo prescricional é quinquenal, nos termos do art. 168, I, do CTN.

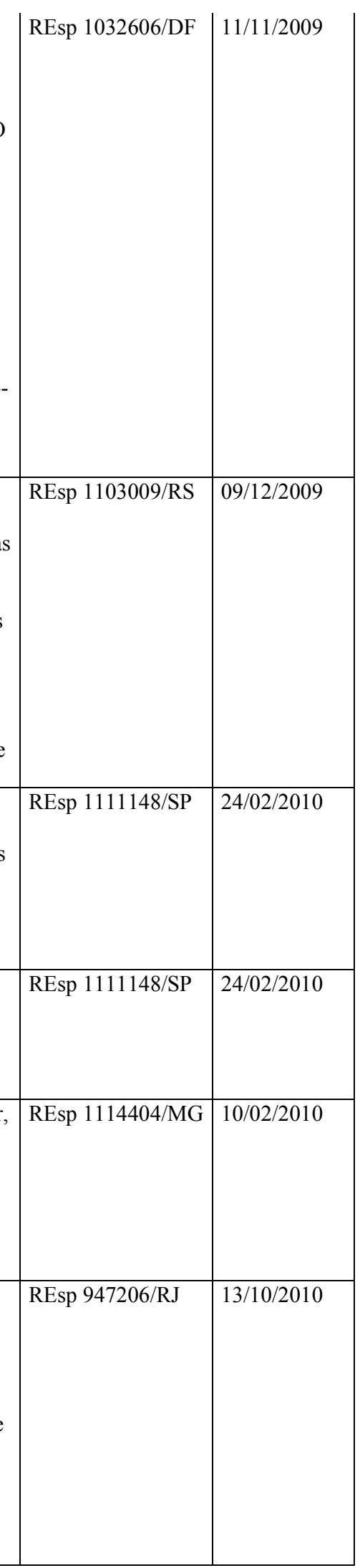


230 Questão referente à possibilidade de o Tribunal a quo se manifestar acerca da base de cálculo e semestralidade do PIS, quando o pedido formulado na inicial cingiu-se à declaração de inexistência de relação jurídica decorrente da incidência dos Decretoslei n. ${ }^{\circ} 2.445 / 88$ e $2.249 / 88$, sem incorrer em julgamento extra petita.

231 Questão referente ao reconhecimento do direito dos procuradores federais à intimação pessoal das decisões proferidas no processo, nos termos do art. 17 da Lei 10.910/2004.

232 Definir se a restituição dos valores indevidamente recolhidos a título de contribuição previdenciária depende da comprovação de que não houve a transferência do custo para o consumidor, consoante estabelece $o$ art. $89, \S 1^{\circ}$, da Lei 8.213/91.

233 Discute sobre a legalidade da cobrança de juros remuneratórios devidos em contratos bancários, desde que (i) não haja prova da taxa pactuada ou (ii) a cláusula ajustada entre as partes não tenha indicado o percentual a ser observado.
O recurso de apelação devolve, em profundidade, o conhecimento da matéria impugnada, ainda que não resolvida pela sentença, nos termos dos parágrafos $1^{\circ}$ e $2^{\circ}$ do art. 515 do $\mathrm{CPC}$, aplicável a regra iura novit curia. Consequentemente, o Tribunal a quo pode se manifestar acerca da base de cálculo e do regime da semestralidade do PIS, máxime em face da declaração de inconstitucionalidade dos Decretos-lei n. $2.445 / 88$ e $2.249 / 88$

Os Procuradores Federais e os Procuradores do Banco Central, consoante preconizado no art. $17 \mathrm{da}$ Lei 10.910, de 15 de julho de 2004, têm como prerrogativa o recebimento da intimação pessoal.

Na repetição do indébito tributário referente a recolhimento de tributo direto, não se impõe a comprovação de que não houve repasse do encargo financeiro decorrente da incidência do imposto ao consumidor final, contribuinte de fato.

Nos contratos de mútuo em que a disponibilização do capital é imediata o montante dos juros remuneratórios praticados deve ser consignado no respectivo instrumento. Ausente a fixação da taxa no contrato o juiz deve limitar os juros à média de mercado nas operações da espécie, divulgada pelo Bacen, salvo se a taxa cobrada for mais vantajosa para o cliente.
234 Discute-se a legalidade da cobrança de juros remuneratórios devidos em contratos bancários, desde que (i) não haja prova da taxa pactuada ou (ii) a cláusula ajustada entre as partes não tenha indicado o percentual a ser observado.

Nos contratos de mútuo em que a disponibilização do capital é imediata o montante dos juros remuneratórios praticados deve ser consignado no respectivo instrumento. Ausente a fixação da taxa no contrato o juiz deve limitar os juros à média de mercado nas operações da espécie, divulgada pelo Bacen, salvo se a taxa cobrada for mais vantajosa para $o$ cliente. Em qualquer hipótese, é possível a correção para a taxa média se for verificada abusividade nos juros remuneratórios praticados.

235 Questão referente à possibilidade ou não de inclusão dos expurgos inflacionários nos cálculos da correção monetária, quando não expressamente postulados pelo autor na fase de conhecimento.

236 Questão referente à legitimidade de terceiro prejudicado para interpor agravo de instrumento em execução na qual houve ordem de penhora de créditos de sua titularidade.

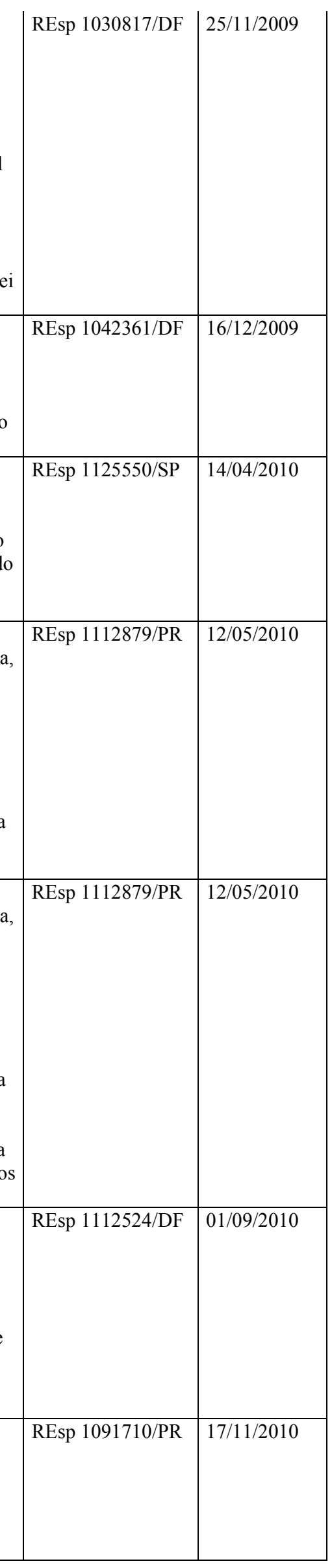


237 Questão referente à possibilidade de oferecimento de garantia, em sede de ação cautelar, para a suspensão da exigibilidade do crédito tributário, cujo respectivo executivo fiscal ainda não foi ajuizado, visando à obtenção de certidão positiva com efeitos de negativa.

238 Questão referente à possibilidade de instituições de ensino que se dediquem exclusivamente às atividades de creche, pré-escolas e ensino fundamental optarem pelo SIMPLES.

239 Questão referente à possibilidade de apreciação, em sede de ação rescisória (com o afastamento da Súmula 343 do STF), da questão relativa à isenção do imposto renda em relação às contribuições recolhidas sob a égide da Lei 7.713/88 para a formação do fundo de aposentadoria, cujo ônus fosse exclusivamente do participante.

40 Questão referente à incidência de imposto de renda sobre o resultado das aplicações financeiras realizadas pelas Cooperativas.

241 Questão referente à ilegitimidade da exigência de depósito prévio como condição de procedibilidade da ação anulatória de crédito tributário (art. 38 da Lei 6.830/80).

242 Questão referente à possibilidade de creditamento de ICMS incidente sobre a energia elétrica consumida em estabelecimento comercial, à luz da Lei Complementar 87/96.

É possível ao contribuinte, após o vencimento da sua obrigação e antes da execução, garantir o juízo de forma antecipada, para o fim de obter certidão positiva com efeito de negativa.

A opção pelo Simples de

estabelecimentos dedicados às atividades de creche, pré-escola e ensino fundamental é admitida somente a partir de 24/10/2000, data de vigência da Lei n. 10.034/2000.

A Súmula 343, do Supremo Tribunal Federal, cristalizou o entendimento de que não cabe ação rescisória por ofensa a literal disposição de lei, quando a decisão rescindenda se tiver baseado em texto legal de interpretação controvertida nos tribunais. A ação rescisória resta cabível, se, à época do julgamento cessara a divergência, hipótese em que o julgado divergente, ao revés de afrontar a jurisprudência, viola a lei que confere fundamento jurídico ao pedido.

O imposto de renda incide sobre o resultado positivo das aplicações financeiras realizadas pelas cooperativas, por não caracterizarem 'ato cooperativos típicos'.

\begin{tabular}{|l|l|l}
\hline O depósito prévio previsto no art. 38, & REsp 962838/BA & 25/11/2009
\end{tabular} da LEF, não constitui condição de procedibilidade da ação anulatória, mas mera faculdade do autor, para o efeito de suspensão da exigibilidade do crédito tributário, nos termos do art. 151 do CTN, inibindo, dessa forma, o ajuizamento da ação executiva fiscal.

As atividades de panificação e de
congelamento de produtos perecíveis", 'rotisseria e restaurante', 'açougue e peixaria' e 'frios e laticínios' (...) por supermercado não configuram processo de industrialização de alimentos, (...) razão pela qual inexiste direito ao creditamento do ICMS pago na entrada da energia elétrica consumida no estabelecimento comercial.

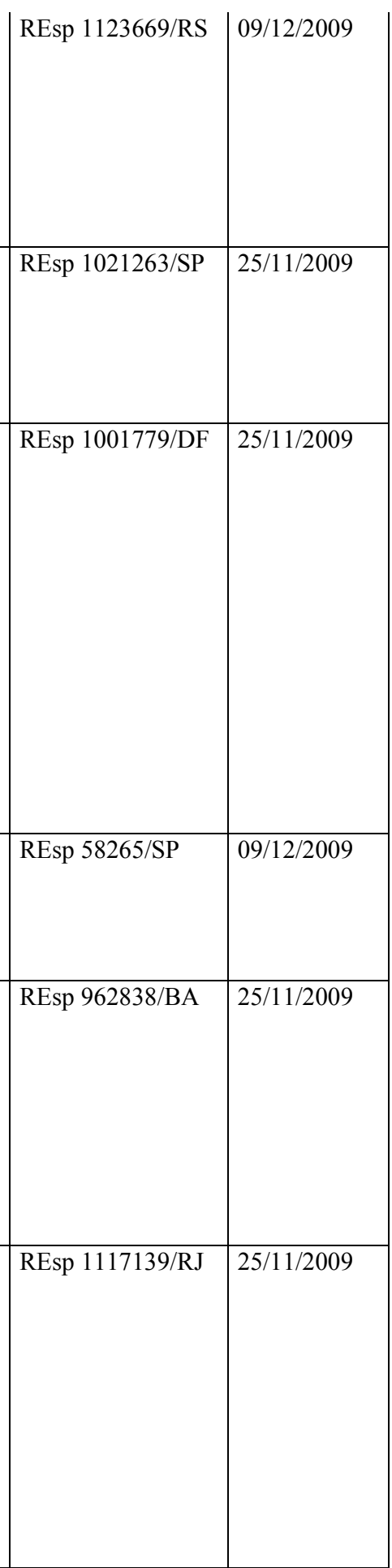




\begin{tabular}{|c|c|c|c|c|}
\hline 243 & $\begin{array}{l}\text { Questão referente aos requisitos } \\
\text { necessários à caracterização da fraude } \\
\text { de execução envolvendo bens imóveis, } \\
\text { excetuadas as execuções de natureza } \\
\text { fiscal. }\end{array}$ & $\begin{array}{l}\text { Para fins do art. 543-c do CPC, firma- } \\
\text { se a seguinte orientação: } 1.1 \text {. É } \\
\text { indispensável citação válida para } \\
\text { configuração da fraude de execução, } \\
\text { ressalvada a hipótese prevista no } \S 3^{\circ} \\
\text { do art. } 615 \text {-A do CPC.1.2. O } \\
\text { reconhecimento da fraude de } \\
\text { execução depende do registro da } \\
\text { penhora do bem alienado ou da prova } \\
\text { de má-fé do terceiro adquirente } \\
\text { (Súmula n. } 375 / \text { STJ). 1.3. A } \\
\text { presunção de boa-fé é princípio geral } \\
\text { de direito universalmente aceito, } \\
\text { sendo milenar parêmia: a boa-fé se } \\
\text { presume; a má-fé se prova. } 1.4 . \\
\text { Inexistindo registro da penhora na } \\
\text { matrícula do imóvel, é do credor o } \\
\text { ônus da prova de que o terceiro } \\
\text { adquirente tinha conhecimento de } \\
\text { demanda capaz de levar o alienante à } \\
\text { insolvência, sob pena de torna-se letra } \\
\text { morta o disposto no art. } 659, \S 4^{\circ} \text {, do } \\
\text { CPC. 1.5. Conforme previsto no } \S 3^{\circ} \\
\text { do art. 615-A do CPC, presume-se em } \\
\text { fraude de execução a alienação ou } \\
\text { oneração de bens realizada após } \\
\text { averbação referida no dispositivo. }\end{array}$ & REsp 956943/PR & $20 / 08 / 2014$ \\
\hline 245 & $\begin{array}{l}\text { Questão referente ao condicionamento } \\
\text { da homologação da opção pelo REFIS } \\
\text { à prestação de garantia no valor do } \\
\text { débito exequendo ou ao arrolamento } \\
\text { de bens, na hipótese em que a dívida } \\
\text { consolidada seja superior a R\$ } \\
500.000,00 \text { (art. } 3^{\circ}, \S \S 4^{\circ} \text { e } 5^{\circ} \text {, da Lei } \\
9.964 / 00) \text {. }\end{array}$ & $\begin{array}{l}\text { A suspensão da exigibilidade do } \\
\text { crédito tributário superior a } \\
\text { quinhentos mil reais para opção pelo } \\
\text { Refis pressupõe a homologação } \\
\text { expressa do comitê gestor e a } \\
\text { constituição de garantia por meio do } \\
\text { arrolamento de bens. }\end{array}$ & REsp 1133710/GO & $25 / 11 / 2009$ \\
\hline 246 & $\begin{array}{l}\text { Questão referente à possibilidade ou } \\
\text { não de capitalização de juros mensais } \\
\text { em contratos bancários, especialmente } \\
\text { após a entrada em vigor do art. } 5^{\circ} \text { da } \\
\text { Medida Provisória n. } 2170-36 / 2001 \text {. }\end{array}$ & $\begin{array}{l}\text { É permitida a capitalização de juros } \\
\text { com periodicidade inferior a um ano } \\
\text { em contratos celebrados após } \\
\text { 31.3.2000, data da publicação da } \\
\text { Medida Provisória n. } 1.963-17 / 2000 \\
\text { (em vigor como MP } 2.170-36 / 2001 \text { ), } \\
\text { desde que expressamente pactuada. }\end{array}$ & REsp 973827/RS & $08 / 08 / 2012$ \\
\hline 247 & $\begin{array}{l}\text { Questão referente à possibilidade ou } \\
\text { não de capitalização de juros mensais } \\
\text { em contratos bancários, especialmente } \\
\text { após a entrada em vigor do art. } 5^{\circ} \text { da } \\
\text { Medida Provisória n. } 2170-36 / 2001 \text {. }\end{array}$ & $\begin{array}{l}\text { A capitalização dos juros em } \\
\text { periodicidade inferior à anual deve vir } \\
\text { pactuada de forma expressa e clara. A } \\
\text { previsão no contrato bancário de taxa } \\
\text { de juros anual superior ao duodécuplo } \\
\text { da mensal é suficiente para permitir a } \\
\text { cobrança da taxa efetiva anual } \\
\text { contratada. }\end{array}$ & REsp 973827/RS & $08 / 08 / 2012$ \\
\hline 248 & $\begin{array}{l}\text { Questiona-se se incumbe ao Município } \\
\text { o ônus da prova da remessa e } \\
\text { recebimento do carnê de cobrança da } \\
\text { taxa de licença para funcionamento ao } \\
\text { endereço do contribuinte, sob pena de } \\
\text { nulidade da CDA. }\end{array}$ & $\begin{array}{l}\text { O envio da guia de cobrança (carnê), } \\
\text { da taxa de licença para } \\
\text { funcionamento, ao endereço do } \\
\text { contribuinte, configura a notificação } \\
\text { presumida do lançamento do tributo, } \\
\text { passível de ser ilidida pelo } \\
\text { contribuinte, a quem cabe comprovar } \\
\text { seu não recebimento. }\end{array}$ & REsp 1114780/SC & $12 / 05 / 2010$ \\
\hline
\end{tabular}


249 Questão referente à possibilidade de alteração do valor constante na Certidão da Dívida Ativa, quando configurado o excesso de execução, desde que a operação importe meros cálculos aritméticos, sendo certa a inexistência de mácula à liquidez do título executivo.
250 Questão referente à natureza do rol de moléstias graves constante do art. $6^{\circ}$, XIV, da Lei 7.713/88 - se taxativa ou exemplificativa -, de modo a possibilitar, ou não, a concessão de isenção de imposto de renda a aposentados portadores de outras doenças graves e incuráveis.
251 Questão referente à definição da natureza jurídica da remuneração cobrada pelo fornecimento de água e esgoto por concessionária de serviço público (se taxa ou tarifa/preço público) para fins de fixação do prazo prescricional.

252 Questão referente à definição da natureza jurídica da remuneração cobrada pelo fornecimento de água e esgoto por concessionária de serviço público (se taxa ou tarifa/preço público) para fins de fixação do prazo prescricional.
O prosseguimento da execução fiscal (pelo valor remanescente daquele constante do lançamento tributário ou do ato de formalização do contribuinte fundado em legislação posteriormente declarada inconstitucional em sede de controle difuso) revela-se forçoso em face da suficiência da liquidação do título executivo, consubstanciado na sentença proferida nos embargos à execução, que reconheceu o excesso cobrado pelo Fisco, sobressaindo a higidez do ato de constituição do crédito tributário, o que, a fortiori, dispensa a emenda ou substituição da certidão de dívida ativa (CDA).

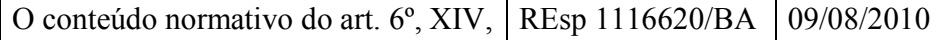
da Lei 7.713/88, com as alterações promovidas pela Lei 11.052/2004, é explícito em conceder o benefício fiscal em favor dos aposentados portadores das seguintes moléstias graves: moléstia profissional, tuberculose ativa, alienação mental, esclerose múltipla, neoplasia maligna, cegueira, hanseníase, paralisia irreversível e incapacitante, cardiopatia grave, doença de Parkinson, espondiloartrose anquilosante, nefropatia grave, hepatopatia grave, estados avançados da doença de Paget (osteíte deformante), contaminação por radiação, síndrome da

imunodeficiência adquirida, com base em conclusão da medicina especializada, mesmo que a doença tenha sido contraída depois da aposentadoria ou reforma. Por conseguinte, o rol contido no referido dispositivo legal é taxativo (numerus clausus), vale dizer, restringe a concessão de isenção às situações nele enumeradas.

A natureza jurídica da remuneração dos serviços de água e esgoto, prestados por concessionária de serviço público, é de tarifa ou preço público, consubstanciando, assim, contraprestação de caráter nãotributário, razão pela qual não se subsume ao regime jurídico tributário estabelecido para as taxas.

É vintenário o prazo prescricional da pretensão executiva atinente à tarifa por prestação de serviços de água e esgoto, cujo vencimento, na data da entrada em vigor do Código Civil de 2002, era superior a dez anos. Ao revés, cuidar-se-á de prazo prescricional decenal.

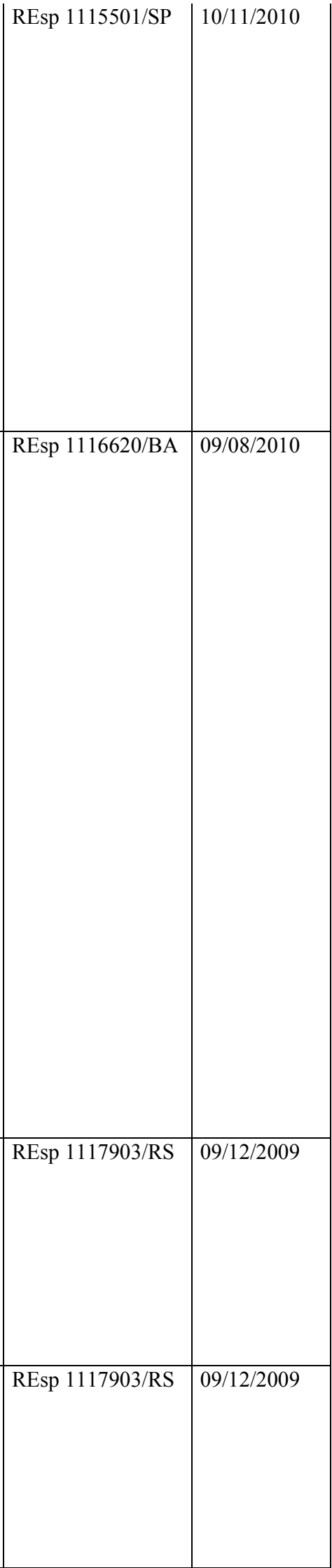


253 Questão referente à definição da natureza jurídica da remuneração cobrada pelo fornecimento de água e esgoto por concessionária de serviço público (se taxa ou tarifa/preço público) para fins de fixação do prazo prescricional.

254 Questão referente à definição da natureza jurídica da remuneração cobrada pelo fornecimento de água e esgoto por concessionária de serviço público (se taxa ou tarifa/preço público) para fins de fixação do prazo prescricional.

255 Questão referente à possibilidade de cobrança dos créditos provenientes de operações de crédito rural cedido à União pelo Banco do Brasil, nos termos da MP 2.196-3/2001, pelo rito da execução fiscal.
256 Questão referente à legitimidade da recusa de expedição de certidão positiva com efeitos de negativa, na hipótese de existência de declaração de tributo sujeito ao lançamento por homologação (DCTF) sem a antecipação do respectivo pagamento.

257 Questão referente à forma de extinção da ação de embargos, no caso de adesão a acordo de parcelamento de dívida (REFIS ou PAES) - se com ou sem resolução de mérito.
258 Questão referente à possibilidade de utilização do mandado de segurança como via adequada à obtenção da declaração do direito de compensação, nos termos da Súmula 213 do STJ, em oposição à utilização do mandamus como meio de validação, pelo Poder Judiciário, da compensação anteriormente efetuada.

259 Questão referente à não-incidência do ICMS sobre o mero deslocamento de equipamentos ou mercadorias entre estabelecimentos da titularidade do mesmo contribuinte, em razão da ausência de circulação econômica para fins de transferência de propriedade.

260 Questiona-se a impossibilidade de deferimento ex officio de reforço da penhora realizada validamente no executivo fiscal, a teor dos artigos 15 , II, da LEF e 667 e 685 do CPC.
A natureza jurídica da remuneração dos serviços de água e esgoto, prestados por concessionária de serviço público, é de tarifa ou preço público, consubstanciando, assim, contraprestação de caráter nãotributário, razão pela qual não se subsume ao regime jurídico tributário estabelecido para as taxas.

É vintenário o prazo prescricional da pretensão executiva atinente à tarifa por prestação de serviços de água e esgoto, cujo vencimento, na data da entrada em vigor do Código Civil de 2002, era superior a dez anos. Ao revés, cuidar-se-á de prazo prescricional decenal.

Os créditos rurais originários de operações financeiras alongadas ou renegociadas (cf. Lei n. 9.138/95), cedidos à União por força da Medida Provisória 2.196-3/2001, estão abarcados no conceito de Dívida Ativa da União para efeitos de execução fiscal - não importando a natureza pública ou privada dos créditos em si.

Declarado e não pago o débito tributário pelo contribuinte, é legítima a recusa de expedição de certidão negativa ou positiva com efeito de negativa.

Na esfera judicial, a renúncia sobre os direitos em que se funda a ação que discute débitos incluídos em parcelamento especial deve ser expressa, porquanto o preenchimento dos pressupostos para a inclusão da empresa no referido programa é matéria que deve ser verificada pela autoridade administrativa, fora do âmbito judicial.

É incabível o mandado de segurança para convalidar a compensação tributária realizada pelo contribuinte.

Não constitui fato gerador do ICMS o simples deslocamento de mercadoria de um para outro estabelecimento do mesmo contribuinte.

O reforço da penhora não pode ser

deferido ex officio, a teor dos artigos 15, II, da LEF e 685 do CPC. \begin{tabular}{|l|l|} 
REsp 1117903/RS & $09 / 12 / 2009$
\end{tabular}

REsp 1117903/RS 09/12/2009

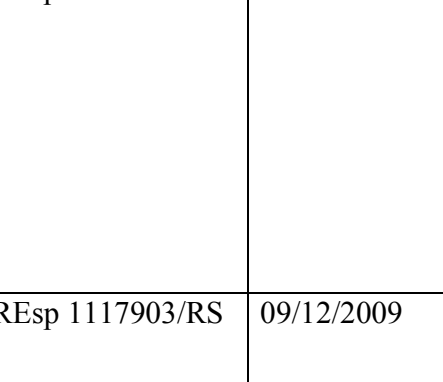

REsp 1123539/RS $09 / 12 / 2009$


261 Questiona-se a cobrança de diferencial de alíquota de ICMS sobre operações interestaduais, realizadas por empresa de construção civil, na aquisição de material a ser empregado na obra que executa.

262 Questina-se a possibilidade de argüição de prescrição em sede de exceção de pré-executividade, ainda que fundada na inconstitucionalidade da lei ordinária que ampliou o prazo prescricional (artigo 46, da Lei 8.212/91).

263 Questiona-se a legalidade da aplicação da sistemática de recolhimento da contribuição destinada ao PIS, constante da Lei Complementar 7/70, no período de outubro de 1995 a fevereiro de 1996.

264 Questão referente à impossibilidade de exclusão dos dados do devedor do CADIN, ante a mera discussão judicial da dívida, sem que sejam observados os requisitos do art. $7^{\circ}$ da Lei $10.722 / 2002$.

265 Questão referente à aplicabilidade das leis disciplinadoras dos regimes de compensação relativos aos tributos administrados pela Secretaria da Receita Federal.
As empresas de construção civil não estão obrigadas a pagar ICMS sobre mercadorias adquiridas como insumos em operações interestaduais.

A prescrição, causa extintiva do crédito tributário, é passível de ser veiculada em exceção de préexecutividade, máxime quando fundada na inconstitucionalidade.

A contribuição social destinada ao PIS permaneceu exigível no período compreendido entre outubro de 1995 a fevereiro de 1996, por força da Lei Complementar 7/70, e entre março de 1996 a outubro de 1998, por força da Medida Provisória 1.212/95 e suas reedições.

A mera discussão judicial da dívida, sem garantia idônea ou suspensão da exigibilidade do crédito, nos termos do art. 151 do CTN, não obsta a inclusão do nome do devedor no CADIN.

Em se tratando de compensação tributária, deve ser considerado o regime jurídico vigente à época do ajuizamento da demanda, não podendo ser a causa julgada à luz do direito superveniente, tendo em vista o inarredável requisito do prequestionamento, viabilizador do conhecimento do apelo extremo, ressalvando-se o direito de $o$ contribuinte proceder à compensação dos créditos pela via administrativa, em conformidade com as normas posteriores, desde que atendidos os requisitos próprios.

266 Questão referente ao prazo decadencial das contribuições previdenciárias, cujos fatos geradores são anteriores à vigência da Constituição Federal de 1988.

267 Questão referente à ilegalidade da inclusão do valor do transporte (frete) na base de cálculo da contribuição previdenciária ao FUNRURAL, por não integrar o valor comercial do produto rural.

268 Questão referente à desnecessidade da instrução da petição inicial da execução fiscal com o demonstrativo de cálculo, uma vez não estar arrolado entre os requisitos essenciais impostos pela Lei 6.830/80, sendo inaplicável à
O prazo prescricional, no que tange às contribuições previdenciárias, foi sucessivamente modificado pela $\mathrm{EC}$ n. $8 / 77$, pela Lei $6.830 / 80$, pela $\mathrm{CF} / 88$ e pela Lei 8.212/91, à medida em que as mesmas adquiriam ou perdiam sua natureza de tributo. (...) O prazo decadencial, por seu turno, não foi alterado pelos referidos diplomas legais, mantendo-se obediente ao disposto na lei tributária.

$\mathrm{O}$ valor do frete configura parcela estranha ao produto rural, por isso que não está inserido na base de cálculo da contribuição para o FUNRURAL, que consiste tão-somente no valor comercial do produto rural, correspondente ao preço pelo qual é vendido pelo produtor.

É desnecessária a apresentação do demonstrativo de cálculo, em execução fiscal, uma vez que a Lei n. 6.830/80 dispõe, expressamente, sobre os requisitos essenciais para a instrução da petição inicial e não

\begin{tabular}{|c|c|}
\hline REsp 1135489/AL & $09 / 12 / 2009$ \\
\hline REsp 1136144/RJ & $09 / 12 / 2009$ \\
\hline REsp 1136210/PR & $09 / 12 / 2009$ \\
\hline REsp 1137497/CE & $14 / 04 / 2010$ \\
\hline REsp 1137738/SP & $09 / 12 / 2009$ \\
\hline REsp 1138159/SP & $25 / 11 / 2009$ \\
\hline REsp 1138159/SP & $25 / 11 / 2009$ \\
\hline REsp 1138202/ES & 09/12/2009 \\
\hline
\end{tabular}




\begin{tabular}{|c|c|c|c|c|}
\hline & espécie o art. 614, II, do CPC. & $\begin{array}{l}\text { elenca o demonstrativo de débito } \\
\text { entre eles. }\end{array}$ & & \\
\hline 269 & $\begin{array}{l}\text { Questão referente à fixação, pelo } \\
\text { Poder Judiciário, de prazo razoável } \\
\text { para a conclusão de processo } \\
\text { administrativo fiscal. }\end{array}$ & $\begin{array}{l}\text { Tanto para os requerimentos } \\
\text { efetuados anteriormente à vigência da } \\
\text { Lei } 11.457 / 07 \text {, quanto aos pedidos } \\
\text { protocolados após o advento do } \\
\text { referido diploma legislativo, o prazo } \\
\text { aplicável é de } 360 \text { dias a partir do } \\
\text { protocolo dos pedidos (art. } 24 \text { da Lei } \\
11.457 / 07 \text { ). }\end{array}$ & REsp 1138206/RS & $09 / 08 / 2010$ \\
\hline 270 & $\begin{array}{l}\text { Questão referente à fixação, pelo } \\
\text { Poder Judiciário, de prazo razoável } \\
\text { para a conclusão de processo } \\
\text { administrativo fiscal. }\end{array}$ & $\begin{array}{l}\text { Tanto para os requerimentos } \\
\text { efetuados anteriormente à vigência da } \\
\text { Lei } 11.457 / 07 \text {, quanto aos pedidos } \\
\text { protocolados após o advento do } \\
\text { referido diploma legislativo, o prazo } \\
\text { aplicável é de } 360 \text { dias a partir do } \\
\text { protocolo dos pedidos (art. } 24 \text { da Lei } \\
11.457 / 07) \text {. }\end{array}$ & REsp 1138206/RS & $09 / 08 / 2010$ \\
\hline 271 & $\begin{array}{l}\text { Questão referente à impossibilidade de } \\
\text { ajuizamento de executivo fiscal } \\
\text { enquanto pendente de julgamento ação } \\
\text { anulatória de lançamento fiscal, em } \\
\text { face da suspensão da exigibilidade do } \\
\text { crédito tributário pelo depósito do } \\
\text { montante integral do débito, nos } \\
\text { termos do artigo 151, inciso II, do } \\
\text { CTN. }\end{array}$ & $\begin{array}{l}\text { Os efeitos da suspensão da } \\
\text { exigibilidade pela realização do } \\
\text { depósito integral do crédito } \\
\text { exequendo, quer no bojo de ação } \\
\text { anulatória, quer no de ação } \\
\text { declaratória de inexistência de relação } \\
\text { jurídico-tributária, ou mesmo no de } \\
\text { mandado de segurança, desde que } \\
\text { ajuizados anteriormente à execução } \\
\text { fiscal, têm o condão de impedir a } \\
\text { lavratura do auto de infração, assim } \\
\text { como de coibir o ato de inscrição em } \\
\text { dívida ativa e o ajuizamento da } \\
\text { execução fiscal, a qual, acaso } \\
\text { proposta, deverá ser extinta. }\end{array}$ & REsp 1140956/SP & $24 / 11 / 2010$ \\
\hline 272 & $\begin{array}{l}\text { Questiona-se a higidez do } \\
\text { aproveitamento de crédito de ICMS, } \\
\text { realizado pelo adquirente de boa-fé, no } \\
\text { que pertine às operações de circulação } \\
\text { de mercadorias cujas notas fiscais } \\
\text { (emitidas pela empresa vendedora) } \\
\text { tenham sido, posteriormente, } \\
\text { declaradas inidôneas, à luz do disposto } \\
\text { no artigo 23, da Lei Complementar } \\
\text { 87/96. }\end{array}$ & $\begin{array}{l}\text { O comerciante de boa-fé que adquire } \\
\text { mercadoria, cuja nota fiscal (emitida } \\
\text { pela empresa vendedora) } \\
\text { posteriormente seja declarada } \\
\text { inidônea, pode engendrar o } \\
\text { aproveitamento do crédito do ICMS } \\
\text { pelo princípio da não-cumulatividade, } \\
\text { uma vez demonstrada a veracidade da } \\
\text { compra e venda efetuada, porquanto o } \\
\text { ato declaratório da inidoneidade } \\
\text { somente produz efeitos a partir de sua } \\
\text { publicação. }\end{array}$ & REsp 1148444/MG & $14 / 04 / 2010$ \\
\hline 273 & $\begin{array}{l}\text { Questão referente à possibilidade de } \\
\text { expedição de certidão de regularidade } \\
\text { fiscal a pessoa jurídica de direito } \\
\text { público quando ajuizada ação } \\
\text { antiexacional (embargos à execução } \\
\text { fiscal ou ação anulatória), na ausência } \\
\text { de penhora ou causa de suspensão de } \\
\text { exigibilidade prevista no art. } 151 \text { do } \\
\text { CTN. }\end{array}$ & $\begin{array}{l}\text { A Fazenda Pública, quer em ação } \\
\text { anulatória, quer em execução } \\
\text { embargada, faz jus à expedição da } \\
\text { certidão positiva de débito com } \\
\text { efeitos negativos, independentemente } \\
\text { de penhora, posto inexpropriáveis os } \\
\text { seus bens. }\end{array}$ & REsp 1123306/SP & $09 / 12 / 2009$ \\
\hline 274 & $\begin{array}{l}\text { Questão referente à incidência do } \\
\text { ICMS sobre a importação de aeronave } \\
\text { sob o regime de arrendamento simples } \\
\text { (leasing operacional). }\end{array}$ & $\begin{array}{l}\text { O arrendamento mercantil, contratado } \\
\text { pela indústria aeronáutica de grande } \\
\text { porte para viabilizar o uso, pelas } \\
\text { companhias de navegação aérea, de } \\
\text { aeronaves por ela construídas, não } \\
\text { constitui operação relativa à } \\
\text { circulação de mercadoria sujeita à } \\
\text { incidência do ICMS. }\end{array}$ & REsp 1131718/SP & $24 / 03 / 2010$ \\
\hline
\end{tabular}


275 Questão referente à possibilidade da aplicação retroativa da Lei Complementar 105/2001 (que revogou o artigo 38, da Lei 4.595/64, que condicionava a quebra do sigilo bancário à obtenção de autorização judicial) para fins de viabilização da constituição do crédito tributário.
276 Questão referente ao direito de creditamento de IPI, no momento da saída de produto tributado do estabelecimento industrial, no que pertine às operações de aquisição de matéria-prima ou insumo isento, não tributado.

277 Questão referente ao direito de creditamento de IPI, no momento da saída de produto tributado do estabelecimento industrial, no que pertine às operações de aquisição de matéria-prima ou insumo sujeito à alíquota zero.

278 Questiona-se a legitimidade da incidência da base de cálculo de ICM sobre o valor total das operações de fornecimento de alimentação e bebidas por bares, restaurantes e similares.

279 Questiona-se a inclusão ou não das quantias recebidas a título de pagamento de salários e encargos sociais dos trabalhadores na base de cálculo da contribuição social destinada ao PIS e da COFINS devidas por empresas que, além da prestação de serviço de locação de mão-de-obra temporária (Lei 6.019/74), exercem a atividade de prestação de serviços especializados de limpeza, portaria, conservação, transporte, telefonista, jardinagem, dentre outros, fornecidos na forma de mão-de-obra terceirizada.

280 Questão referente à incidência de juros compensatórios nas desapropriações para fins de reforma agrária quando improdutivo o imóvel.

281 Questão referente à incidência de juros compensatórios nas desapropriações para fins de reforma agrária quando improdutivo o imóvel.
As leis tributárias procedimentais ou formais, conducentes à constituição do crédito tributário não alcançado pela decadência, são aplicáveis a fatos pretéritos, razão pela qual a Lei 8.021/90 e a Lei Complementar $105 / 2001$, por envergarem essa natureza, legitimam a atuação fiscalizatória/investigativa da Administração Tributária, ainda que os fatos imponíveis a serem apurados lhes sejam anteriores.

A aquisição de matéria-prima e/ou insumo não tributados ou sujeitos à alíquota zero, utilizados na industrialização de produto tributado pelo IPI, não enseja direito ao creditamento do tributo pago na saída do estabelecimento industrial.

A aquisição de matéria-prima e/ou insumo não tributados ou sujeitos à alíquota zero, utilizados na industrialização de produto tributado pelo IPI, não enseja direito ao creditamento do tributo pago na saída do estabelecimento industrial.

\begin{tabular}{|l|l|l|l}
\hline O ICMS incide sobre o fornecimento & REsp 1135534/PE & 09/12/2009
\end{tabular} de alimentação e bebidas em bares, restaurantes e estabelecimentos congêneres, cuja base de cálculo compreende o valor total das operações realizadas, inclusive aquelas correspondentes à prestação de serviço.

A base de cálculo do PIS e da COFINS, independentemente do regime normativo aplicável (Leis Complementares 7/70 e 70/91 ou Leis ordinárias 10.637/2002 e

$10.833 / 2003$ ), abrange os valores recebidos pelas empresas prestadoras de serviços de locação de mão de obra temporária (regidas pela Lei 6.019/1974 e pelo Decreto $73.841 / 1974)$, a título de pagamento de salários e encargos sociais dos trabalhadores temporários.

A eventual improdutividade do imóvel não afasta o direito aos juros compensatórios, pois esses restituem não só o que o expropriado deixou de ganhar com a perda antecipada, mas também a expectativa de renda, considerando a possibilidade do imóvel ser aproveitado a qualquer momento de forma racional e adequada, ou até ser vendido com o recebimento do seu valor à vista.

São indevidos juros compensatórios quando a propriedade se mostrar impassível de qualquer espécie de exploração econômica seja atual ou futura, em decorrência de limitações legais ou da situação geográfica ou topográfica do local onde se situa a

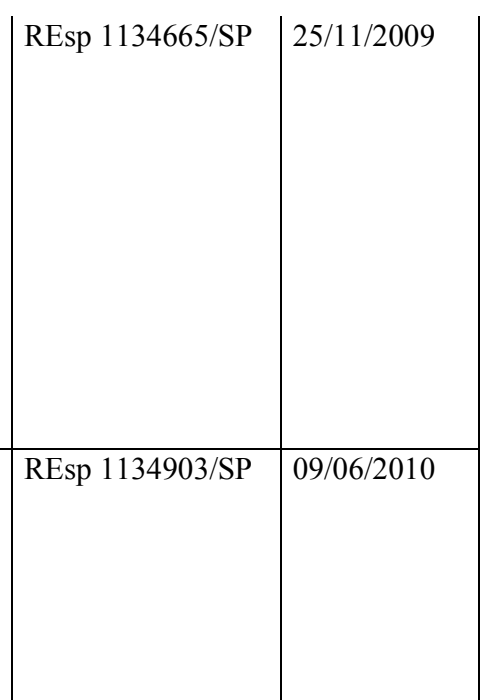

REsp 1134903/SP $09 / 06 / 2010$

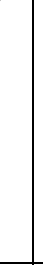

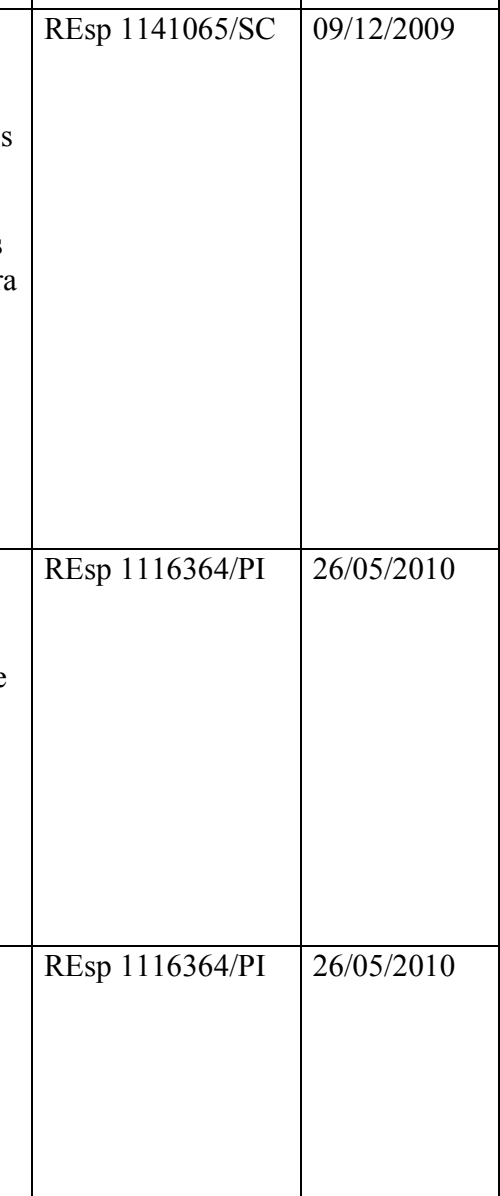




\begin{tabular}{|c|c|c|c|c|}
\hline & & propriedade. & & \\
\hline 282 & $\begin{array}{l}\text { Questão referente à incidência de juros } \\
\text { compensatórios nas desapropriações } \\
\text { para fins de reforma agrária quando } \\
\text { improdutivo o imóvel. }\end{array}$ & $\begin{array}{l}\text { Para aferir a incidência dos juros } \\
\text { compensatórios em imóvel } \\
\text { improdutivo, deve ser observado o } \\
\text { princípio do tempus regit actum, } \\
\text { assim como acontece na fixação do } \\
\text { percentual desses juros. As restrições } \\
\text { contidas nos } \S \S 1^{\circ} \text { e } 2^{\circ} \text { do art. } 15-A, \\
\text { inseridas pelas MP's n. } 1.901-30 / 99 \text { e } \\
2.027-38 / 00 \text { e reedições, as quais } \\
\text { vedam a incidência de juros } \\
\text { compensatórios em propriedade } \\
\text { improdutiva, serão aplicáveis, tão } \\
\text { somente, às situações ocorridas após a } \\
\text { sua vigência. }\end{array}$ & REsp 1116364/PI & $26 / 05 / 2010$ \\
\hline 283 & $\begin{array}{l}\text { Questão referente à incidência de juros } \\
\text { compensatórios nas desapropriações } \\
\text { para fins de reforma agrária quando } \\
\text { improdutivo o imóvel. }\end{array}$ & $\begin{array}{l}\text { Para aferir a incidência dos juros } \\
\text { compensatórios em imóvel } \\
\text { improdutivo, deve ser observado o } \\
\text { princípio do tempus regit actum, } \\
\text { assim como acontece na fixação do } \\
\text { percentual desses juros. Publicada a } \\
\text { medida liminar concedida na ADI } \\
2.332 / D F \text { (DJU de } 13.09 .2001 \text { ), deve } \\
\text { ser suspensa a aplicabilidade dos } \S \S \\
1^{\circ} \text { e } 2^{\circ} \text { do artigo } 15-A \text { do Decreto-lei } \\
\text { n. } 3.365 / 41 \text { até que haja o julgamento } \\
\text { de mérito da demanda. }\end{array}$ & REsp 1116364/PI & $26 / 05 / 2010$ \\
\hline 284 & $\begin{array}{l}\text { Questão referente à possibilidade de } \\
\text { reconhecimento ex officio da ausência } \\
\text { de cópia da petição do agravo de } \\
\text { instrumento, do comprovante de sua } \\
\text { interposição, assim como da relação } \\
\text { dos documentos que instruíram o } \\
\text { recurso, nos termos do art. } 526 \text { do } \\
\text { CPC. }\end{array}$ & $\begin{array}{l}\text { O descumprimento das providências } \\
\text { enumeradas no caput do art. } 526 \text { do } \\
\text { CPC, adotáveis no prazo de três dias, } \\
\text { somente enseja as consequências } \\
\text { dispostas em seu parágrafo único se o } \\
\text { agravado suscitar a questão formal no } \\
\text { momento processual oportuno, sob } \\
\text { pena de preclusão. }\end{array}$ & REsp 1008667/PR & $18 / 11 / 2009$ \\
\hline 285 & $\begin{array}{l}\text { Questão referente à validade da } \\
\text { intimação na qual, malgrado conste o } \\
\text { nome correto do advogado, há } \\
\text { equívoco quanto ao número de } \\
\text { inscrição na OAB. }\end{array}$ & $\begin{array}{l}\text { A ausência ou o equívoco quanto ao } \\
\text { número da inscrição do advogado na } \\
\text { Ordem dos Advogados do Brasil - } \\
\text { OAB não gera nulidade da intimação } \\
\text { da sentença, máxime quando } \\
\text { corretamente publicados os nomes das } \\
\text { partes e respectivos patronos, } \\
\text { informações suficientes para a } \\
\text { identificação da demanda. }\end{array}$ & REsp 1131805/SC & $03 / 03 / 2010$ \\
\hline 286 & $\begin{array}{l}\text { Questão referente à validade da } \\
\text { intimação na qual, malgrado conste o } \\
\text { nome correto do advogado, há } \\
\text { equívoco quanto ao número de } \\
\text { inscrição na OAB. }\end{array}$ & $\begin{array}{l}\text { A ausência ou o equívoco quanto ao } \\
\text { número da inscrição do advogado na } \\
\text { Ordem dos Advogados do Brasil - } \\
\text { OAB não gera nulidade da intimação } \\
\text { da sentença, máxime quando } \\
\text { corretamente publicados os nomes das } \\
\text { partes e respectivos patronos, } \\
\text { informações suficientes para a } \\
\text { identificação da demanda. Nada } \\
\text { obstante, é certo que a existência de } \\
\text { homonímia torna relevante o } \\
\text { equívoco quanto ao número da } \\
\text { inscrição na OAB, uma vez que a } \\
\text { parte é induzida em erro, sofrendo } \\
\text { prejuízo imputável aos serviços } \\
\text { judiciários. }\end{array}$ & REsp 1131805/SC & $03 / 03 / 2010$ \\
\hline
\end{tabular}


287 Questão referente à alegada impenhorabilidade absoluta de bem imóvel, sede da empresa individual executada, por força do disposto no artigo 649, V, do CPC.

288 Questiona-se a possibilidade de ajuizamento de novos embargos à execução restritos aos aspectos formais de nova penhora efetuada.

289 Questiona-se a configuração de renúncia tácita na hipótese em que a exeqüente, intimada a se manifestar pela satisfação integral do crédito exeqüendo ou pelo prosseguimento da execução de sentença, queda-se inerte, dando azo à extinção do processo, com arrimo no artigo 794, I, do CPC.

293 Questão referente à aplicação do art. $42, \S$ único, do CDC à hipótese de repetição dos valores indevidamente repassados ao consumidor, nas contas de telefone, a título de PIS/COFINS, pelas concessionárias de serviços de telecomunicações.

294 Questão referente à possibilidade de alegação da compensação nos embargos à execução, em decorrência do advento da Lei n. ${ }^{\circ} 8.383 / 91$, desde que se trate de crédito líquido e certo, como o resultante de declaração de inconstitucionalidade da exação, bem como quando existente lei específica permissiva da compensação.

95 Cinge-se a controvérsia sobre a taxa de juros de mora a ser aplicada na repetição de indébito da contribuição previdenciária estadual cobrada de inativos entre a EC 20/98 e a edição da Lei Complementar Paulista n. ${ }^{\circ}$ 954/03, se $o$ art. $1^{\circ}-\mathrm{F}$ da Lei 9.494/97, como entendeu o aresto recorrido, ou o art. $161 \mathrm{c} / \mathrm{c} 167$, parágrafo único, do CTN, como afirmam os recorrentes.

297 Questiona-se a inexistência do início de prova material a corroborar os testemunhos apresentados, impossibilitando, desta forma, o reconhecimento do trabalho rural, nos termos da Súmula 149 do STJ.
É legítima a penhora da sede do estabelecimento comercial.

É admissível o ajuizamento de novos embargos de devedor, ainda que nas hipóteses de reforço ou substituição da penhora, quando a discussão adstringir-se aos aspectos formais do novo ato constritivo. A renúncia ao crédito exequendo remanescente, com a consequente extinção do processo satisfativo, reclama prévia intimação, vedada a presunção de renúncia tácita.

O repasse econômico do PIS e da

COFINS realizados pelas empresas concessionárias de serviços de telecomunicação é legal e condiz com as regras de economia e de mercado.

A compensação efetuada pelo contribuinte, antes do ajuizamento do feito executivo, pode figurar como fundamento de defesa dos embargos à execução fiscal, a fim de ilidir a presunção de liquidez e certeza da $\mathrm{CDA}$, máxime quando, à época da compensação, restaram atendidos os requisitos da existência de crédito tributário compensável, da configuração do indébito tributário, e da existência de lei específica autorizativa da citada modalidade extintiva do crédito tributário.

Na restituição do indébito tributário, os juros de mora são devidos, à razão de $1 \%$ ao mês, conforme estabelecido no artigo $161, \S 1^{\circ}$, do $\mathrm{CTN}$, não prevalecendo o disposto no artigo $1^{\circ}$ F da Lei 9.494/97, acrescentado pela MP 2.180-35/01.

A prova exclusivamente testemunhal não basta à comprovação da atividade rurícola, para efeito da obtenção de benefício previdenciário. \begin{tabular}{l|l} 
REsp $1114767 / \mathrm{RS}$ & $02 / 12 / 2009$
\end{tabular}

REsp 1116287/SP $\quad 02 / 12 / 2009$

REsp 1143471/PR 03/02/2010

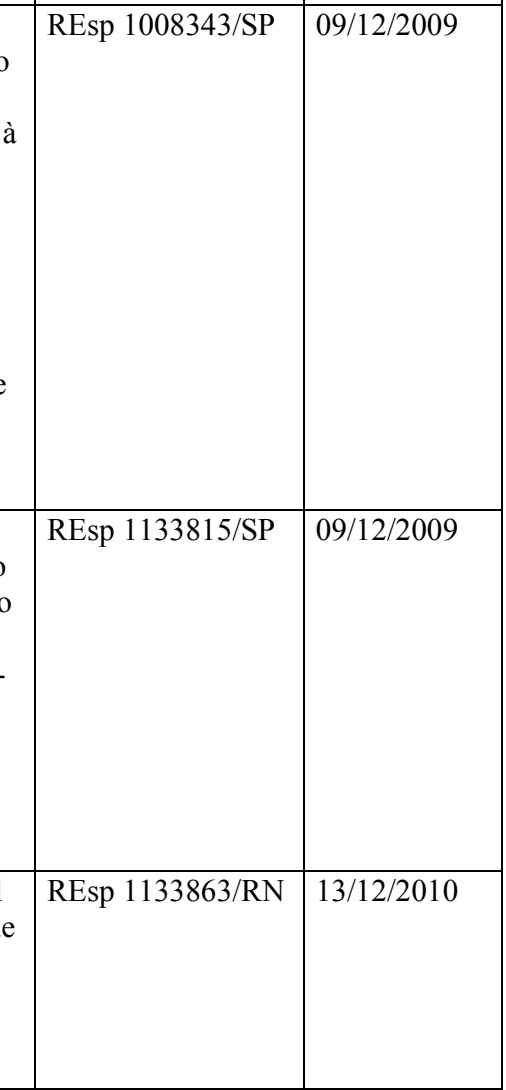


303 Questão referente aos índices aplicáveis para apuração de diferenças de correção monetária de valores depositados em Cadernetas de Poupança, decorrentes de Planos Econômicos.
304 Questão referente aos índices aplicáveis para apuração de diferenças de correção monetária de valores depositados em Cadernetas de Poupança, decorrentes de Planos Econômicos.
Quanto ao Plano Collor I (março/1990), é de 84,32\% fixado com base no índice de Preços ao Consumidor (IPC), conforme disposto nos arts. 10 e 17, III, da Lei 7.730/89, o índice a ser aplicado no mês de março de 1990 aos ativos financeiros retidos até o momento do respectivo aniversário da conta; ressalva-se, contudo, que devem ser atualizados pelo BTN Fiscal os valores excedentes ao limite estabelecido em $\mathrm{NCz} \$ 50.000,00$, que constituíram conta individualizada junto ao BACEN, assim como os valores que não foram transferidos para $o$ BACEN, para as cadernetas de poupança que tiveram os períodos aquisitivos iniciados após a vigência da Medida Provisória 168/90 e nos meses subsequentes ao seu advento (abril, maio e junho de 1990).

Quanto ao Plano Collor II, é de 20,21\%* o índice de correção monetária a ser aplicado no mês de março de 1991, nas hipóteses em que já iniciado o período mensal aquisitivo da caderneta de poupança quando do advento do Plano, pois o poupador adquiriu o direito de ter $\mathrm{o}$ valor aplicado remunerado de acordo com o disposto na Lei n. 8.088/90, não podendo ser aplicado o novo critério de remuneração previsto na Medida Provisória n. 294, de 31.1.1991, convertida na Lei n. 8.177/91.

305 Discussão acerca da legitimidade passiva da Brasil Telecom S/A para responder pelas ações não subscritas da Companhia Riograndense de Telecomunicações.

306 Discussão acerca da legitimidade passiva da Brasil Telecom S/A para responder pelas ações não subscritas da Companhia Riograndense de Telecomunicações, bem como do prazo prescricional para se pleitear o pagamento dos dividendos relativos às ações a serem indenizadas.

307 Discussão acerca da legitimidade passiva da Brasil Telecom S/A para responder pelas ações não subscritas da Companhia Riograndense de Telecomunicações, bem como do prazo prescricional para se pleitear o pagamento dos dividendos relativos às ações a serem indenizadas. integralização do capital.

A Brasil Telecom S/A, como

sucessora por incorporação da

Companhia Riograndense de

Telecomunicações (CRT), tem legitimidade passiva para responder pela complementação acionária decorrente de contrato de participação financeira, celebrado entre adquirente de linha telefônica e a incorporada. \begin{tabular}{ll|l} 
A legitimidade da Brasil Telecom S/A & REsp 1034255/RS & 28/04/2010
\end{tabular} para responder pela chamada 'dobra acionária', relativa às ações da Celular CRT Participações S/A, decorre do protocolo e da justificativa de cisão parcial da Companhia Riograndense de Telecomunicações (CRT), premissa fática infensa à análise do STJ por força das Súmulas 5 e 7.

É devida indenização a título de dividendos ao adquirente de linha telefônica, como decorrência lógica da procedência do pedido de complementação das ações da CRT/Celular CRT, a contar do ano da

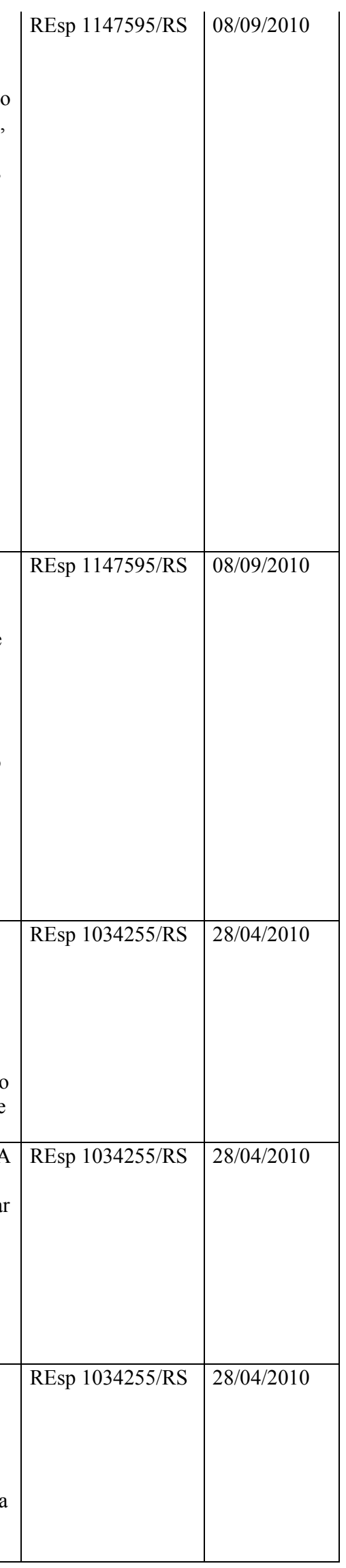


308 Discussão acerca da legitimidade passiva da Brasil Telecom S/A para responder pelas ações não subscritas da Companhia Riograndense de Telecomunicações, bem como do prazo prescricional para se pleitear o pagamento dos dividendos relativos às ações a serem indenizadas.

309 Discussão acerca da legitimidade passiva da Brasil Telecom S/A para responder pelas ações não subscritas da Companhia Riograndense de Telecomunicações, bem como do prazo prescricional para se pleitear o pagamento dos dividendos relativos às ações a serem indenizadas.

310 Controvérsia subjacente diz respeito ao prazo de prescrição para a cobrança de investimento feito por usuário em rede de eletrificação rural.

11 Controvérsia subjacente diz respeito ao prazo de prescrição para a cobrança de investimento feito por usuário em rede de eletrificação rural.

A pretensão de cobrança de indenização decorrente de dividendos relativos à subscrição complementar das ações da CRT/Celular CRT prescreve em três anos, nos termos do art. 206, $\S 3^{\circ}$, inciso III, do Código

Civil de 2002, somente começando a correr tal prazo após o reconhecimento do direito à complementação acionária. A pretensão de cobrança de indenização decorrente de dividendos relativos à subscrição complementar das ações da CRT/Celular CRT prescreve em três anos, nos termos do art. 206, $\S 3^{\circ}$, inciso III, do Código

Civil de 2002, somente começando a correr tal prazo após o reconhecimento do direito à complementação acionária.

Prescreve em 20 (vinte) anos, na vigência do Código Civil de 1916, e em 5 (cinco) anos, na vigência do Código Civil de 2002, a pretensão de cobrança dos valores aportados para a construção de rede de eletrificação rural, posteriormente incorporada ao patrimônio da CEEE/RGE, respeitada a regra de transição prevista no art. 2.028 do Código Civil de 2002.

Prescreve em 20 (vinte) anos, na vigência do Código Civil de 1916, e em 5 (cinco) anos, na vigência do Código Civil de 2002, a pretensão de cobrança dos valores aportados para a construção de rede de eletrificação rural, posteriormente incorporada ao patrimônio da CEEE/RGE, respeitada a regra de transição prevista no art. 2.028 do Código Civil de 2002.

312 Controvérsia subjacente diz respeito a restituição das parcelas pagas em consórcio em caso de desfazimento do contrato.

314 Questão referente à viabilidade da extinção ex officio do processo de execução fiscal não embargada, com base no art. 267, III, do CPC, restando afastado o Enunciado Sumular 240 do STJ.

15 Questão referente à inexistência de litisconsórcio passivo necessário entre a União e a Eletrobrás, em demanda que versa sobre questões relativas ao empréstimo compulsório de energia elétrica, em face da faculdade de o contribuinte eleger apenas um dos
É devida a restituição de valores

vertidos por consorciado desistente ao

grupo de consórcio, mas não de imediato, e sim em até trinta dias a contar do prazo previsto

contratualmente para o encerramento do plano.

A inércia da Fazenda exequente, ante a intimação regular para promover $o$ andamento do feito e a observância dos artigos 40 e 25 da Lei de Execução Fiscal, implica a extinção da execução fiscal não embargada ex officio, afastando-se o Enunciado Sumular 240 do STJ, segundo o qual 'A extinção do processo, por abandono da causa pelo autor, depende de requerimento do réu'. Matéria impassível de ser alegada pela exequente contumaz.

A parte autora pode eleger apenas um dos devedores solidários para figurar no pólo passivo da demanda. (...) A possibilidade de escolha de um dos devedores solidários afasta a figura do litisconsórcio compulsório ou necessário.

\begin{tabular}{|c|c|}
\hline REsp 1112474/RS & $28 / 04 / 2010$ \\
\hline REsp 1112474/RS & $28 / 04 / 2010$ \\
\hline REsp 1063661/RS & $24 / 02 / 2010$ \\
\hline REsp 1063661/RS & $24 / 02 / 2010$ \\
\hline REsp 1119300/RS & $14 / 04 / 2010$ \\
\hline REsp 112009//SP & 13/10/2010 \\
\hline REsp 1145146/RS & 09/12/2009 \\
\hline
\end{tabular}




\begin{tabular}{|c|c|c|c|c|}
\hline & devedores solidários. & & & \\
\hline 316 & $\begin{array}{l}\text { Questão referente à incidência ou não } \\
\text { da modificação do art. } 475 \text { do CPC, } \\
\text { promovida pela Lei } 10.352 / 2001 \text {, que } \\
\text { limitou o cabimento da remessa oficial } \\
\text { apenas às decisões desfavoráveis à } \\
\text { Fazenda Pública que sejam superiores } \\
\text { a } 60 \text { (sessenta) salários mínimos. }\end{array}$ & $\begin{array}{l}\text { A incidência do duplo grau de } \\
\text { jurisdição obrigatório é imperiosa } \\
\text { quando a resolução do processo } \\
\text { cognitivo for anterior à reforma } \\
\text { engendrada pela Lei } 10.352 / 2001 \text {. }\end{array}$ & REsp 1144079/SP & $02 / 03 / 2011$ \\
\hline 317 & $\begin{array}{l}\text { Questão referente à definição do foro } \\
\text { competente para o ajuizamento da } \\
\text { execução fiscal, à luz do art. } 578 \text { do } \\
\text { CPC. }\end{array}$ & $\begin{array}{l}\text { O devedor não tem assegurado o } \\
\text { direito de ser executado no foro de } \\
\text { seu domicílio, salvo se nenhuma das } \\
\text { espécies do parágrafo único se } \\
\text { verificar. }\end{array}$ & REsp 1120276/PA & $09 / 12 / 2009$ \\
\hline 318 & $\begin{array}{l}\text { Discute-se a aplicação do prazo } \\
\text { prescricional previsto no Decreto-Lei } \\
\text { n. } 20.910 / 32 \text {. }\end{array}$ & $\begin{array}{l}\text { O prazo prescricional para ação } \\
\text { ajuizada para reaver o quantum pago } \\
\text { a maior, em decorrência da majoração } \\
\text { da tarifa de energia elétrica pelas } \\
\text { Portarias } 38 / 86 \text { e } 45 / 86 \text {, é de } 20 \text { anos. }\end{array}$ & REsp 1110321/DF & $28 / 04 / 2010$ \\
\hline 319 & $\begin{array}{l}\text { Discute-se a ilegalidade das Portarias } \\
\text { do DNAEE n. } 38 / 86 \text { e } 45 / 86 \text { e, de } \\
\text { 4/3/1986, que majoraram as tarifas de } \\
\text { energia elétrica quando da vigência do } \\
\text { Plano Cruzado, que instituiu o } \\
\text { congelamento de todos os preços } \\
\text { públicos e privados. }\end{array}$ & $\begin{array}{l}\text { A majoração da tarifa de energia } \\
\text { elétrica estabelecida pelas Portarias } \\
\text { do DNAEE } 38 / 86 \text { e } 45 / 86 \text { é ilegítima, } \\
\text { por terem desrespeitado o } \\
\text { congelamento de preços instituído } \\
\text { pelo cognominado 'Plano Cruzado'. } \\
\text { Ressalta-se, todavia, a legalidade dos } \\
\text { reajustes das tarifas ocorridos a partir } \\
\text { da vigência da Portaria } 153 / 86 \text {, de } \\
27.11 .86 \text {, editada quando não mais } \\
\text { vigiam os referidos diplomas legais. } \\
\text { (...) A ilegalidade da majoração da } \\
\text { tarifa de energia elétrica estabelecida } \\
\text { pelas Portarias } 38 / 86 \text { e } 45 / 86 \text { deve ser } \\
\text { aferida da seguinte forma: a) aos } \\
\text { consumidores industriais atingidos } \\
\text { pelo congelamento, devesse-lhes } \\
\text { reconhecer o direito à repetição da } \\
\text { tarifa majorada, e; b) aos } \\
\text { consumidores residenciais não assiste } \\
\text { o direito à repetição. }\end{array}$ & REsp 1110321/DF & $28 / 04 / 2010$ \\
\hline 320 & $\begin{array}{l}\text { Questiona-se a possibilidade de } \\
\text { conversão, ex officio, de ação } \\
\text { executiva que não preenche os } \\
\text { requisitos de certeza, liquidez e } \\
\text { exigibilidade em ação monitória. }\end{array}$ & $\begin{array}{l}\text { É inadmissível a conversão, de ofício } \\
\text { ou a requerimento das partes, da } \\
\text { execução em ação monitória após ter } \\
\text { ocorrido a citação. }\end{array}$ & REsp 1129938/PE & $28 / 09 / 2011$ \\
\hline 321 & $\begin{array}{l}\text { Questiona-se a natureza jurídica do } \\
\text { prazo estabelecido no art. } 284 \text { do } \\
\text { Código de Processo Civil, à luz da } \\
\text { hipótese de justa causa prevista no art. } \\
183 \text { do mesmo diploma legal. }\end{array}$ & $\begin{array}{l}\text { O prazo do art. } 284 \text { do Código de } \\
\text { Processo Civil não é peremptório, } \\
\text { mas dilatório, ou seja, pode ser } \\
\text { reduzido ou ampliado por convenção } \\
\text { das partes ou por determinação do } \\
\text { juiz. }\end{array}$ & REsp 1133689/PE & $28 / 03 / 2012$ \\
\hline 322 & $\begin{array}{l}\text { Questiona-se a fixação de um VMAA } \\
\text { nacional, a partir do menor valor } \\
\text { encontrado em cada Estado ou no } \\
\text { Distrito Federal, porquanto o } \\
\text { FUNDEF tem natureza de fundo } \\
\text { regional. }\end{array}$ & $\begin{array}{l}\text { Para fins de complementação pela } \\
\text { União ao Fundo de Manutenção e } \\
\text { Desenvolvimento do Ensino } \\
\text { Fundamental - FUNDEF (art. } 60 \text { do } \\
\text { ADCT, redação da EC } 14 / 96 \text { ), o 'valor } \\
\text { mínimo anual por aluno' (VMAA), de } \\
\text { que trata o art. } 6^{\circ}, \S 1^{\circ} \text { da Lei } \\
9.424 / 96 \text {, deve ser calculado levando } \\
\text { em conta a média nacional. }\end{array}$ & REsp 1101015/BA & $26 / 05 / 2010$ \\
\hline
\end{tabular}


323 Questão referente à possibilidade, ou não, da segunda quitação do saldo residual relativo a contrato de financiamento para aquisição de residência própria, entabulado pelas regras do Sistema Financeiro da Habitação - SFH, com a utilização de recursos provenientes do Fundo de Compensação de Variações Salariais FCVS, nos termos da Leis 4.380/64, $8.004 / 99$ e $8.100 / 99$.

324 Cinge-se a controvérsia sobre o prazo prescricional para a cobrança de multa administrativa por infração à legislação do meio ambiente aplicada por órgão ou entidade da

Administração Pública Federal, direta ou indireta: se quinquenal, nos termos do art. $1^{\circ}$ do Decreto 20.910/32, ou vintenária, segundo o art. 177 do Código Civil de 1916

325 Cinge-se a controvérsia sobre o prazo prescricional para a cobrança de multa administrativa por infração à legislação do meio ambiente aplicada por órgão ou entidade da

Administração Pública Federal, direta ou indireta: se quinquenal, nos termos do art. $1^{\circ}$ do Decreto 20.910/32, ou vintenária, segundo o art. 177 do Código Civil de 1916.

326 Cinge-se a controvérsia sobre o prazo prescricional para a cobrança de multa administrativa por infração à legislação do meio ambiente aplicada por órgão ou entidade da

Administração Pública Federal, direta ou indireta: se quinquenal, nos termos do art. $1^{\circ}$ do Decreto 20.910/32, ou vintenária, segundo o art. 177 do Código Civil de 1916.

327 Cinge-se a controvérsia sobre o prazo prescricional para a cobrança de multa administrativa por infração à legislação do meio ambiente aplicada por órgão ou entidade da Administração Pública Federal, direta ou indireta: se quinquenal, nos termos do art. $1^{\circ}$ do Decreto 20.910/32, ou vintenária, segundo o art. 177 do Código Civil de 1916.

328 Cinge-se a controvérsia sobre o prazo prescricional para a cobrança de multa administrativa por infração à legislação do meio ambiente aplicada por órgão ou entidade da Administração Pública Federal, direta ou indireta: se quinquenal, nos termos do art. $1^{\circ}$ do Decreto 20.910/32, ou vintenária, segundo o art. 177 do Código Civil de 1916
O Fundo de Compensação de Variações Salariais - FCVS é responsável pela quitação do saldo residual de segundo financiamento nos contratos celebrados até 05.12.1990, ante a ratio essendi do art. $3^{\circ}$ da Lei 8.100/90, com o redação conferida pela Lei n 10.150 , de 21.12.2001.

É de cinco anos o prazo decadencia para se constituir o crédito decorrente de infração à legislação administrativa.

O prazo decadencial para constituição do crédito decorrente de infração à legislação administrativa 'conta-se da data da infração', 'caso se trate de ilícito instantâneo'.

O prazo decadencial para constituição do crédito decorrente de infração à legislação administrativa, 'no caso de infração permanente ou continuada, conta-se do dia em que tiver cessado' o ilícito.

Interrompe-se o prazo decadencial para a constituição do crédito decorrente de infração à legislação administrativa: a) pela notificação ou citação do indiciado ou executado, inclusive por meio de edital; b) por qualquer ato inequívoco, que importe apuração do fato; pela decisão condenatória recorrível; por qualquer ato inequívoco que importe em manifestação expressa de tentativa de solução conciliatória no âmbito interno da administração pública federal.

É de três anos o prazo para a conclusão do processo administrativo instaurado para se apurar a infração administrativa ('prescrição intercorrente').

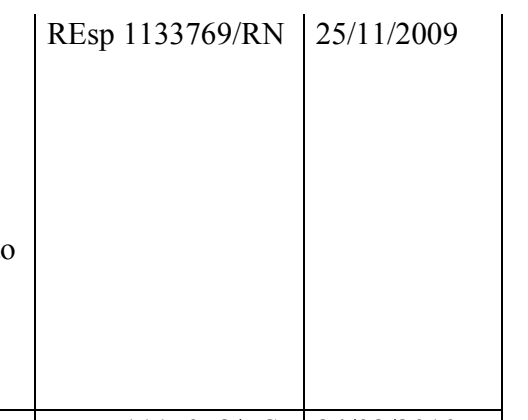

REsp 1115078/RS $24 / 03 / 2010$

\begin{tabular}{l|l} 
REsp 1115078/RS & 24/03/2010
\end{tabular}

REsp 1115078/RS $24 / 03 / 2010$

\begin{tabular}{|l|l|}
\hline REsp 1115078/RS & 24/03/2010 \\
\hline REsp 1115078/RS & $24 / 03 / 2010$ \\
& \\
\end{tabular}


329 Cinge-se a controvérsia sobre o prazo prescricional para a cobrança de multa administrativa por infração à

legislação do meio ambiente aplicada por órgão ou entidade da

Administração Pública Federal, direta ou indireta: se quinquenal, nos termos do art. $1^{\circ}$ do Decreto 20.910/32, ou vintenária, segundo o art. 177 do Código Civil de 1916.

330 Cinge-se a controvérsia sobre o prazo prescricional para a cobrança de multa administrativa por infração à

legislação do meio ambiente aplicada por órgão ou entidade da

Administração Pública Federal, direta ou indireta: se quinquenal, nos termos do art. $1^{\circ}$ do Decreto 20.910/32, ou vintenária, segundo o art. 177 do Código Civil de 1916.

331 Cinge-se a controvérsia sobre o prazo prescricional para a cobrança de multa administrativa por infração à legislação do meio ambiente aplicada por órgão ou entidade da Administração Pública Federal, direta ou indireta: se quinquenal, nos termos do art. $1^{\circ}$ do Decreto 20.910/32, ou vintenária, segundo o art. 177 do Código Civil de 1916.
332 Questiona-se o afastamento da cobrança de laudêmio, na hipótese de transferência do domínio útil de imóvel da União, situado em terreno de marinha, para fins de integralização do capital social de empresa.

333 Questão referente à possibilidade de juntada de documentos destinados à apuração do quantum debeatur relativo ao benefício do crédito prêmio do IPI, em fase de liquidação de sentença.
Prescreve em cinco anos, contados do término do processo administrativo, a pretensão da Administração Pública de promover a execução da multa por infração ambiental.

\section{O termo inicial do prazo prescricional} para o ajuizamento da ação executória 'é a constituição definitiva do crédito, que se dá com o término do processo administrativo de apuração da infração e constituição da dívida'.

São causas de interrupção do prazo prescricional: a) o despacho do juiz que ordenar a citação em executivo fiscal; b) o protesto judicial; c) qualquer ato judicial que constitua em mora o devedor; d) qualquer ato inequívoco, ainda que extrajudicial, que importe em reconhecimento do débito pelo devedor; e) qualquer ato inequívoco que importe em manifestação expressa de tentativa de solução conciliatória no âmbito interno da administração pública federal.

A transferência de domínio útil de imóvel para integralização de capital social de empresa é ato oneroso, de modo que é devida a cobrança de laudêmio, nos termos do art. $3^{\circ}$ do Decreto-Lei 2.398/87.

$\mathrm{Na}$ oportunidade da liquidação da sentença, por se tratar de reconhecimento de crédito-prêmio de IPI, a parte deverá apresentar toda a documentação suficientes à comprovação da efetiva operação de exportação, bem como do ingresso de divisas no País, sem o que não se habilita à fruição do benefício, mesmo estando ele reconhecido na sentença.

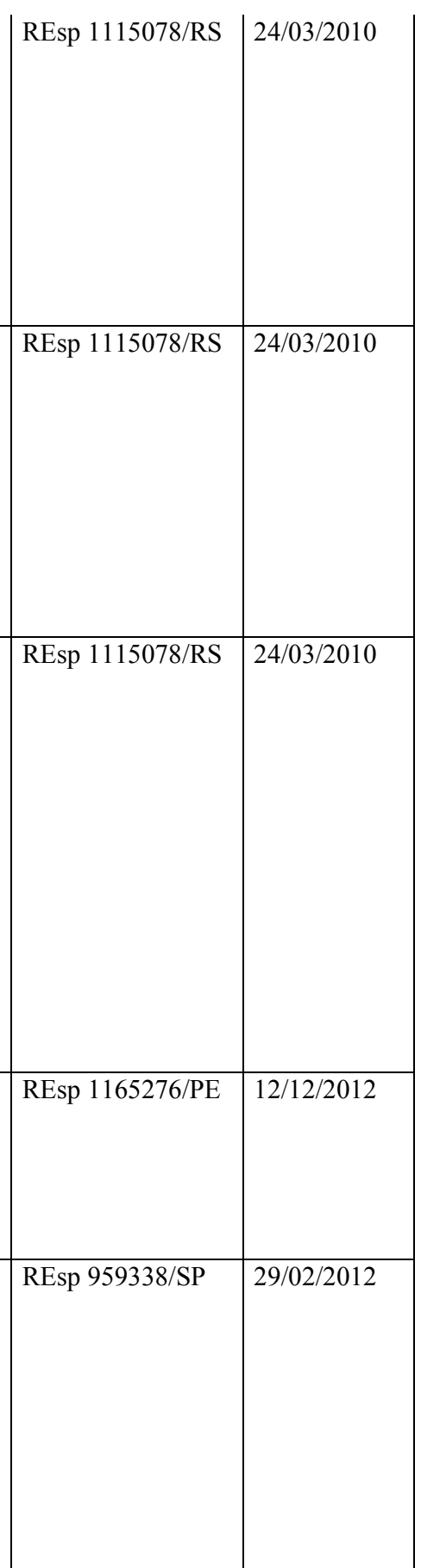


334 Questiona se a responsabilização pessoal dos sócios por débitos previdenciários das sociedades por quotas de responsabilidade limitada, com base no art. 13 da Lei 8.620/93, deve ficar subordinada à verificação das condições estabelecidas no art. 135, III, do CTN.
Também merece provimento quanto à matéria de fundo, que trata da responsabilidade dos sócios em face do disposto no art. 13 da Lei 8.620/93. Na vigência de tal dispositivo (posteriormente revogado de modo expresso pelo art. 79, VII, da Lei 11.941/09), já havia entendimento desta $1^{\text {a }}$ Seção segundo o qual, mesmo em se tratando de débitos para com a Seguridade Social, a responsabilidade pessoal dos sócios das sociedades por quotas de responsabilidade limitada, prevista no art. 13 da Lei 8.620/93, só existe, quando presentes as condições estabelecidas no art. 135, III do CTN. Há, todavia uma razão superior, mais importante que todas as outras, a justificar a inexistência da responsabilidade do sócio, em casos da espécie: o STF, no julgamento do RE 562.276, ocorrido em 03.11.10, relatora a Ministra Ellen Gracie (acórdão pendente de publicação), declarou a inconstitucionalidade do art. 13 da Lei 8.620/93, tanto por vício formal (violação ao art. 146, III, da Constituição Federal), como por vício material (violação aos arts.. $5^{\circ}$, XIII, e 170, parágrafo único, da Constituição Federal. O julgamento do recurso extraordinário se deu sob o regime do art. 543-B do CPC, o que confere especial eficácia vinculativa ao precedente e impõe sua adoção imediata em casos análogos, como o aqui em exame.

335 Questiona-se se, na vigência da Lei 9.711/98, a responsabilidade das empresas cedentes de mão-de-obra pelo recolhimento das contribuições previdenciárias nos casos em que as empresas tomadoras não realizem a retenção e o pagamento ou o efetuem em valor menor que o devido.

A partir da vigência do art. 31 da Lei 8.212/91, com a redação dada pela Lei 9.711/98, a empresa contratante é responsável, com exclusividade, pelo recolhimento da contribuição previdenciária por ela retida do valor bruto da nota fiscal ou fatura de prestação de serviços, afastada, em relação ao montante retido, a responsabilidade supletiva da empresa prestadora, cedente de mão-de-obra.

336 Cinge-se a discussão em saber se a declaração de compensação relativa ao crédito-prêmio de IPI suspende, ou não, a exigibilidade do crédito para efeitos de expedição de certidão positiva com efeitos de negativa.
A simples declaração de compensação

relativa ao crédito-prêmio de IPI não suspende a exigibilidade do crédito tributário - a menos que esteja presente alguma outra causa de suspensão elencada no art. 151 do CTN - , razão porque poderá a Fazenda Nacional recusar-se a emitir a certidão de regularidade fiscal.

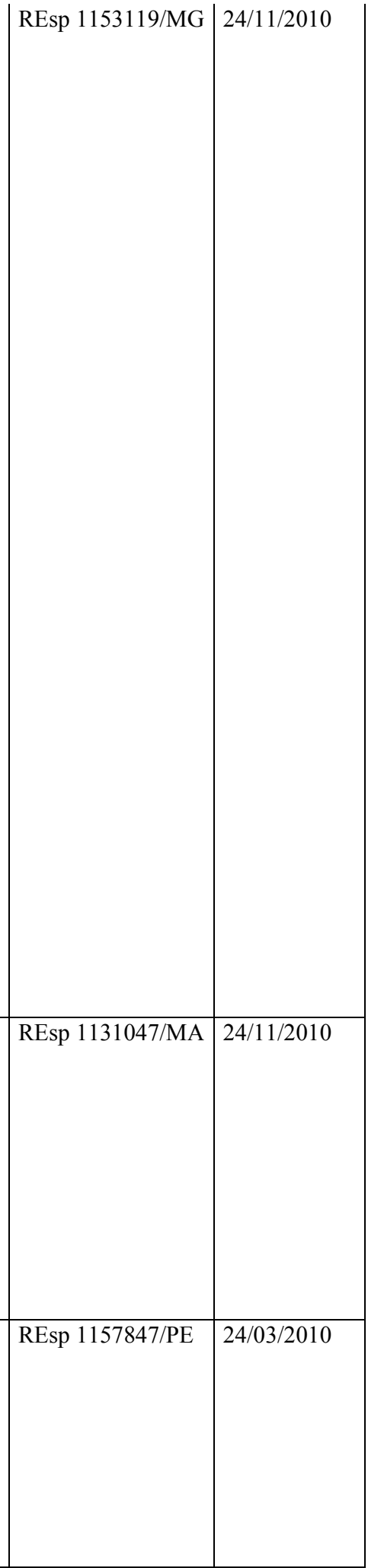


337 Questão referente ao reconhecimento do direito de efetuar a compensação de tributos indevidamente recolhidos a título de PIS com parcelas vincendas do próprio PIS e de outras contribuições arrecadadas pela Receita Federal, decidiu pela ausência de interesse de agir do impetrante, tendo em vista a edição da Instrução Normativa n. 21/97, que eliminou quaisquer óbices à compensação tributária.
338 Questão relativa à incidência de contribuição previdenciária sobre os valores recebidos a título de auxíliocreche.

339 Questiona a legitimidade do ato que condiciona a liberação de veículo apreendido por transporte irregular de passageiros ao pagamento de multas e de demais despesas (Lei 9503/97, art. 231, VIII, c/c Decreto 2521/98, art. 85, $\left.\S 3^{\circ}\right)$.

340 Controvérsia sobre os limites objetivos da coisa julgada, dadas as alterações legislativas posteriores ao trânsito em julgado de sentença declaratória de inexistência de relação jurídica tributária no tocante à Contribuição Social sobre o Lucro Líquido instituída pela Lei 7.689/88.
O interesse de agir se caracteriza pelos entraves rotineiramente opostos pela Secretaria da Receita Federal àquele que postula a compensação tributária dos valores indevidamente recolhidos a maior a título de PIS, sem as exigências que são impostas pela legislação de regência, notadamente em relação ao critérios que envolvem o encontro de contas, à aplicação de expurgos inflacionários no cálculo da correção monetária dos valores a serem repetidos, à incidência de juros moratórios e compensatórios, bem como à definição do prazo prescricional para o exercício do direito à compensação, considerando, em especial, o disposto no $\operatorname{artigo} 3^{\circ}$ da Lei Complementar n. 118/2005. Assim, é inegável a necessidade do contribuinte buscar tutela jurisdicional favorável, a fim de proteger seu direito de exercer o pleno exercício da compensação de que trata o art. 66 da Lei 8.383/91, sem que lhe fosse impingidos os limites previstos nas normas infralegais pela autoridade administrativa.

$\mathrm{O}$ auxílio-creche funciona como

indenização, não integrando o saláriode-contribuição para a Previdência. Inteligência da Súmula 310/STJ.

A liberação do veículo retido por transporte irregular de passageiros, com base no art. 231, VIII, do Código de Trânsito Brasileiro, não está condicionada ao pagamento de multas e despesas.

Não é possível a cobrança da Contribuição Social sobre o Lucro (CSLL) do contribuinte que tem a seu favor decisão judicial transitada em julgado declarando a inconstitucionalidade formal e material da exação conforme concebida pela Lei 7.689/88, assim como a inexistência de relação jurídica material a seu recolhimento. $\mathrm{O}$ fato de o Supremo Tribunal Federal posteriormente manifestar-se em sentido oposto à decisão judicial transitada em julgado em nada pode alterar a relação jurídica estabilizada pela coisa julgada, sob pena de negar validade ao próprio controle difuso de constitucionalidade.

341 Questão referente à exclusão da sociedade empresária do regime de recolhimento de tributos denominado SIMPLES deve produzir efeitos a partir do mês subsequente à situação excludente e não apenas a partir da intimação do contribuinte ou da data constante do ato declaratório da exclusão.

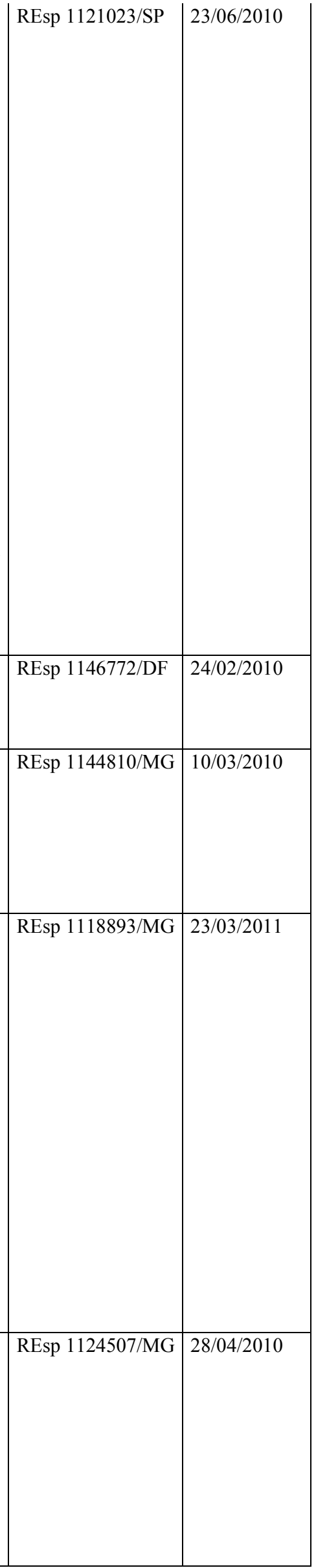




\begin{tabular}{|c|c|c|c|c|}
\hline & & da mesma lei. & & \\
\hline 342 & $\begin{array}{l}\text { Questão referente à legalidade da } \\
\text { imposição do Decreto 332/91 no } \\
\text { sentido de não admitir a exclusão da } \\
\text { parcela relativa à diferença entre o } \\
\text { BTNF e o IPC da base de cálculo da } \\
\text { CSLL, apesar de ser admitida tal } \\
\text { exclusão da base de cálculo do } \\
\text { imposto de renda. }\end{array}$ & $\begin{array}{l}\text { Não há ilegalidade no artigo } 41 \text { do } \\
\text { Decreto n. 332/91, consonante com a } \\
\text { Lei n. 8.200/1, artigo } 1^{\circ} \text {, que, ao } \\
\text { cuidar da correção monetária de } \\
\text { balanço relativamente ao ano-base de } \\
\text { 1990, limitou-se ao IRPJ, não } \\
\text { estendendo a previsão legal à CSLL. }\end{array}$ & REsp 1127610/MG & $23 / 06 / 2010$ \\
\hline 343 & $\begin{array}{l}\text { Questão referente à isenção de custas } \\
\text { em favor da CEF, estabelecida pelo } \\
\text { art. 24-A da MP 1984-23, não a } \\
\text { desobriga de ressarcir as custas } \\
\text { adiantadas pelo autor da ação. } \\
\end{array}$ & $\begin{array}{l}\text { Nas ações em que representa o FGTS, } \\
\text { a CEF, quando sucumbente, não está } \\
\text { isenta de reembolsar as custas } \\
\text { antecipadas pela parte vencedora. }\end{array}$ & REsp 1151364/PE & $24 / 02 / 2010$ \\
\hline 344 & $\begin{array}{l}\text { Questão referente ao cabimento da } \\
\text { dispensa da defesa prévia em ação de } \\
\text { improbidade administrativa, prevista } \\
\text { no art. } 17, \S 7^{\circ} \text {, da Lei } 8.429 / 92, \\
\text { quando instruído o processo com o } \\
\text { inquérito civil promovido pelo } \\
\text { Ministério Público. }\end{array}$ & $\begin{array}{l}\text { O especialíssimo procedimento } \\
\text { estabelecido na Lei } 8.429 / 92 \text {, que } \\
\text { prevê um juízo de delibação para } \\
\text { recebimento da petição inicial (art. } 17 \text {, } \\
\left.\S \S 8^{\circ} \text { e } 9^{\circ}\right) \text {, precedido de notificação } \\
\text { do demandado (art. } 17, \S 7^{\circ} \text { ), somente } \\
\text { é aplicável para ações de improbidade } \\
\text { administrativa típicas. }\end{array}$ & REsp 1163643/SP & $24 / 03 / 2010$ \\
\hline 345 & $\begin{array}{l}\text { Questiona a incidência do comando } \\
\text { inserto no art. 170-A do CTN, } \\
\text { introduzido pela LC 104/01, } \\
\text { relativamente à compensação de } \\
\text { tributo objeto de ações já em curso } \\
\text { quando da entrada em vigor desse } \\
\text { dispositivo. }\end{array}$ & $\begin{array}{l}\text { Em se tratando de compensação de } \\
\text { crédito objeto de controvérsia judicial, } \\
\text { é vedada a sua realização 'antes do } \\
\text { trânsito em julgado da respectiva } \\
\text { decisão judicial', conforme prevê o } \\
\text { art. } 170 \text {-A do CTN, vedação que, } \\
\text { todavia, não se aplica a ações judiciais } \\
\text { propostas em data anterior à vigência } \\
\text { desse dispositivo, introduzido pela LC } \\
\text { 104/2001. }\end{array}$ & REsp 1164452/MG & $25 / 08 / 2010$ \\
\hline 346 & $\begin{array}{l}\text { Questiona o alcance da expressão } \\
\text { 'objeto de contestação judicial pelo } \\
\text { sujeito passivo' constante no art. 170- } \\
\text { A do CTN, introduzido pela LC } \\
\text { 104/01, na hipótese de o crédito do } \\
\text { contribuinte apresentado para } \\
\text { compensação ser de tributo declarado } \\
\text { inconstitucional. }\end{array}$ & $\begin{array}{l}\text { Nos termos do art. 170-A do CTN, 'é } \\
\text { vedada a compensação mediante o } \\
\text { aproveitamento de tributo, objeto de } \\
\text { contestação judicial pelo sujeito } \\
\text { passivo, antes do trânsito em julgado } \\
\text { da respectiva decisão judicial', } \\
\text { vedação que se aplica inclusive às } \\
\text { hipóteses de reconhecida } \\
\text { inconstitucionalidade do tributo } \\
\text { indevidamente recolhido. }\end{array}$ & REsp 1167039/DF & $25 / 08 / 2010$ \\
\hline 347 & $\begin{array}{l}\text { A controvérsia refere-se ao critério de } \\
\text { fixação dos honorários advocatícios } \\
\text { em feito que objetiva a declaração do } \\
\text { direito à compensação tributária, se } \\
\text { deve ser adotado como base de cálculo } \\
\text { o valor da causa - como afirmado no } \\
\text { aresto recorrido - , ou o valor da } \\
\text { condenação - como defende a } \\
\text { recorrente. }\end{array}$ & $\begin{array}{l}\text { Nas demandas de cunho declaratório, } \\
\text { até por inexistir condenação } \\
\text { pecuniária que possa servir de base de } \\
\text { cálculo, os honorários devem ser } \\
\text { fixados com referência no valor da } \\
\text { causa ou em montante fixo. }\end{array}$ & REsp 1155125/MG & $10 / 03 / 2010$ \\
\hline
\end{tabular}


348 Cinge-se a discussão em saber se a câmara de vereadores detém legitimidade ativa para discutir a incidência da contribuição previdenciária sobre a remuneração paga a vereadores.
349 Discute a legalidade da exigência de prestação de garantia pessoal (fiador) para a celebração de contrato de financiamento estudantil vinculado ao FIES.

350 Discute a legalidade da cobrança de juros capitalizados para a celebração de contrato de financiamento estudantil vinculado ao FIES.

351 Questiona a forma de cálculo do Imposto de Renda na fonte, na hipótese de pagamento acumulado de benefícios previdenciários atrasados, vale dizer, se o IR deve ter como parâmetro o valor de cada parcela mensal a que faria jus o beneficiário, ou se deve ser calculado sobre o montante integral creditado.

352 Discute a possibilidade de o credor unilateralmente eleger o agente fiduciário no bojo de execução extrajudicial de contrato regido pelas normas do Sistema Financeiro da Habitação (SFH) com garantia hipotecária.

353 Discute-se a observância do DecretoLei n. 70/66, precisamente acerca da notificação pessoal do devedor para purgação da mora.

356 Questão referente ao prazo prescricional relativo das ações de repetição de indébito relativas à contribuição ao Fusex.

358 Questão referente à legitimidade da recusa do fornecimento de certidão negativa de débito tributário, na hipótese em que a autoridade administrativa competente não procede ao lançamento de ofício supletivo de suposta diferença advinda da compensação efetuada pelo contribuinte, por sua conta e risco, de
A Câmara de Vereadores não possui personalidade jurídica, mas apenas personalidade judiciária, de modo que somente pode demandar em juízo para defender os seus direitos institucionais, entendidos esses como sendo os relacionados ao funcionamento, autonomia $\mathrm{e}$ independência do órgão. No caso, a Câmara de Vereadores do Município de Lagoa do Piauí/PI ajuizou ação ordinária inibitória com pedido de tutela antecipada contra a Fazenda Nacional e o INSS, objetivando afastar a incidência da contribuição previdenciária sobre os vencimentos pagos aos próprios vereadores. Não se trata, portanto, de defesa de prerrogativa institucional, mas de pretensão de cunho patrimonial. É legal a exigência de prestação de garantia pessoal para a celebração de contrato de financiamento estudantil vinculado ao FIES.

Em se tratando de crédito educativo, não se admite sejam os juros capitalizados.

O Imposto de Renda incidente sobre os benefícios previdenciários atrasados pagos acumuladamente deve ser calculado de acordo com as tabelas e alíquotas vigentes à época em que os valores deveriam ter sido adimplidos, observando a renda auferida mês a mês pelo segurado, não sendo legítima a cobrança de IR com parâmetro no montante global pago extemporaneamente.

\begin{tabular}{ll|l} 
A exigência de comum acordo entre o & REsp 1160435/PE & 06/04/2011
\end{tabular} credor e o devedor na escolha do agente fiduciário tão-somente se aplica aos contratos não vinculados ao Sistema Financeiro da Habitação SFH.

Não se cogita perempção da execução extrajudicial na hipótese do não cumprimento do prazo estabelecido pelo $\S 1^{\circ}$ do art. 31 do Decreto-lei $n$. $70 / 66$.

\begin{tabular}{l|l|l}
\hline O prazo prescricional a ser aplicado & REsp 1086382/RS & 14/04/2010
\end{tabular}

às ações de repetição de indébito relativas à contribuição ao FUSEX, que consubstancia tributo sujeito ao lançamento de ofício, é o quinquenal, nos termos do art. 168, I, do CTN.

O descumprimento da obrigação acessória de informar, mensalmente, ao INSS, dados relacionados aos fatos geradores da contribuição previdenciária, é condição impeditiva para expedição da prova de inexistência de débito.

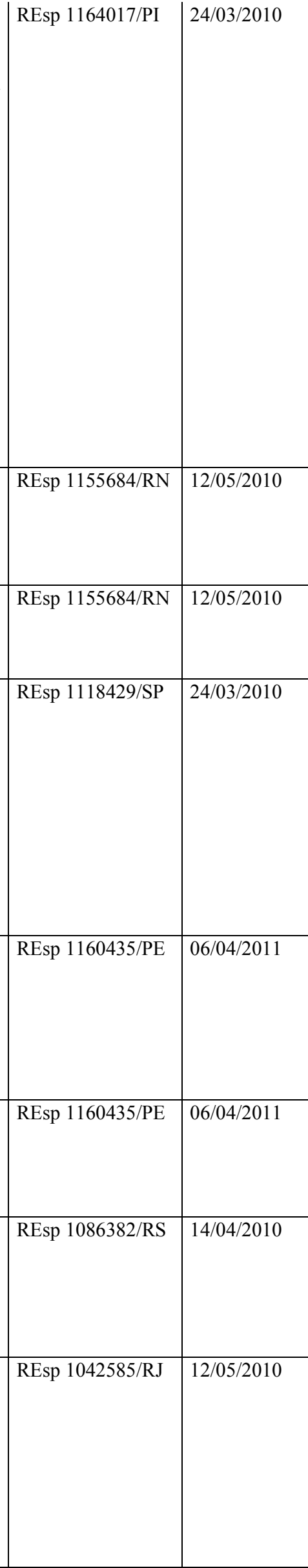




\begin{tabular}{|c|c|c|c|c|}
\hline & $\begin{array}{l}\text { crédito vincendo atinente a tributo } \\
\text { sujeito a lançamento por } \\
\text { homologação. }\end{array}$ & & & \\
\hline 359 & $\begin{array}{l}\text { Questão à violação da coisa julgada } \\
\text { em decorrência da determinação de } \\
\text { incidência da taxa SELIC em sede de } \\
\text { execução de sentença, quando esta } \\
\text { determinou a aplicação de juros de } \\
\text { mora em } 1 \% \text {, posteriormente à } \\
\text { vigência da Lei } 9.250 / 95 \text {. }\end{array}$ & $\begin{array}{l}\text { A fixação de percentual relativo aos } \\
\text { juros moratórios, após a edição da Lei } \\
\text { 9.250/95, em decisão que transitou em } \\
\text { julgado, impede a inclusão da Taxa } \\
\text { SELIC em fase de liquidação de } \\
\text { sentença, sob pena de violação ao } \\
\text { instituto da coisa julgada, porquanto a } \\
\text { referida taxa engloba juros e correção } \\
\text { monetária, não podendo ser cumulada } \\
\text { com qualquer outro índice de } \\
\text { atualização. }\end{array}$ & REsp 1136733/PR & $13 / 10 / 2010$ \\
\hline 360 & $\begin{array}{l}\text { Questão relativa à incidência do } \\
\text { imposto sobre a renda em relação ao } \\
\text { pagamento de verba decorrente de } \\
\text { reintegração do servidor ao cargo por } \\
\text { decisão judicial. }\end{array}$ & $\begin{array}{l}\text { Os valores a serem pagos em razão de } \\
\text { decisão judicial trabalhista, que } \\
\text { determina a reintegração do ex- } \\
\text { empregado, assumem a natureza de } \\
\text { verba remuneratória, atraindo a } \\
\text { incidência do imposto sobre a renda. } \\
\text { Isso porque são percebidos a título de } \\
\text { salários vencidos, como se o } \\
\text { empregado estivesse no pleno } \\
\text { exercício de seu vínculo empregatício. }\end{array}$ & REsp 1142177/RS & $09 / 08 / 2010$ \\
\hline 361 & $\begin{array}{l}\text { Questão relativa à incidência do } \\
\text { Imposto sobre a Renda em relação ao } \\
\text { pagamento de verba decorrente de } \\
\text { reintegração do servidor ao cargo por } \\
\text { decisão judicial. }\end{array}$ & $\begin{array}{l}\text { Sendo a reintegração inviável, os } \\
\text { valores a serem percebidos pelo } \\
\text { empregado amoldam-se à indenização } \\
\text { prevista no artigo } 7^{\circ}, \text { I, da Carta } \\
\text { Maior, em face da natureza } \\
\text { eminentemente indenizatória, não } \\
\text { dando azo a qualquer acréscimo } \\
\text { patrimonial ou geração de renda, } \\
\text { posto não ensejar riqueza nova } \\
\text { disponível, mas reparações, em } \\
\text { pecúnia, por perdas de direitos, } \\
\text { afastando a incidência do Imposto } \\
\text { sobre a Renda. }\end{array}$ & REsp 1142177/RS & $09 / 08 / 2010$ \\
\hline 362 & $\begin{array}{l}\text { Questão referente à sujeição passiva } \\
\text { da relação jurídico-tributária relativa } \\
\text { ao salário-educação, vale dizer, se o } \\
\text { pólo passivo da referida relação é } \\
\text { integrado por empresa em sentido lato } \\
\text { ou em sentido estrito. }\end{array}$ & $\begin{array}{l}\text { A contribuição para o salário- } \\
\text { educação tem como sujeito passivo as } \\
\text { empresas, assim entendidas as firmas } \\
\text { individuais ou sociedades que } \\
\text { assumam o risco de atividade } \\
\text { econômica, urbana ou rural, com fins } \\
\text { lucrativos ou não, em consonância } \\
\text { com o art. } 15 \text { da Lei 9.424/96, } \\
\text { regulamentado pelo Decreto } 3.142 / 99 \text {, } \\
\text { sucedido pelo Decreto } 6.003 / 2006 \text {. }\end{array}$ & REsp 1162307/RJ & $24 / 11 / 2010$ \\
\hline 364 & $\begin{array}{l}\text { Discute-se a subsistência da isenção da } \\
\text { COFINS incidente sobre o } \\
\text { faturamento/receita das sociedades } \\
\text { civis prestadoras de serviços de } \\
\text { profissão legalmente regulamentada, } \\
\text { prevista no artigo } 6^{\circ} \text {, II, da Lei } \\
\text { Complementar } 70 / 91 \text {, tendo em vista a } \\
\text { revogação perpetrada pelo artigo } 56 \text {, } \\
\text { da Lei } 9.430 / 96 \text {. }\end{array}$ & $\begin{array}{l}\text { A Contribuição para Financiamento } \\
\text { da Seguridade Social - COFINS } \\
\text { incide sobre o faturamento das } \\
\text { sociedades civis de prestação de } \\
\text { serviços de profissão legalmente } \\
\text { regulamentada, de que trata o artigo } \\
1^{\circ} \text {, do Decreto-Lei } 2.397 / 87, \text { tendo em } \\
\text { vista a validade da revogação da } \\
\text { isenção prevista no artigo } 6^{\circ} \text {, II, da } \\
\text { Lei Complementar } 70 / 91 \text { (lei } \\
\text { materialmente ordinária), perpetrada } \\
\text { pelo artigo 56, da Lei } 9.430 / 96 .\end{array}$ & REsp 826428/MG & $09 / 06 / 2010$ \\
\hline
\end{tabular}




\begin{tabular}{|c|c|c|c|c|}
\hline 366 & $\begin{array}{l}\text { Questão referente à não incidência do } \\
\text { Imposto sobre a Renda em relação à } \\
\text { complementação do benefício de } \\
\text { pensão recebida de entidades de } \\
\text { previdência privada, em razão da } \\
\text { morte do participante ou contribuinte } \\
\text { do fundo de assistência, considerando- } \\
\text { se o disposto no art. } 32 \text { da Lei no } \\
\text { 9.250/95, que alterou o art. } 6^{\circ} \text {, VII, } \\
\text { "a", da Lei n }{ }^{\circ} 7.713 / 88 \text {. }\end{array}$ & $\begin{array}{l}\text { A complementação da pensão } \\
\text { recebida de entidades de previdência } \\
\text { privada, em decorrência da morte do } \\
\text { participante ou contribuinte do fundo } \\
\text { de assistência, quer a título de } \\
\text { benefício quer de seguro, não sofre a } \\
\text { incidência do Imposto de Renda } \\
\text { apenas sob a égide da Lei } 7.713 / 88, \\
\text { art. } 6^{\circ}, \text { VII, "a", que restou revogado } \\
\text { pela Lei } 9.250 / 95, \text { a qual, retornando } \\
\text { ao regime anterior, previu a } \\
\text { incidência do imposto de renda no } \\
\text { momento da percepção do benefício. }\end{array}$ & REsp 1086492/PR & $13 / 10 / 2010$ \\
\hline 367 & $\begin{array}{l}\text { Discute-se a legalidade da autuação } \\
\text { fiscal do contribuinte que, ao proceder } \\
\text { ao simples deslocamento de } \\
\text { mercadoria de um para outro } \\
\text { estabelecimento próprio (operação que } \\
\text { não constitui hipótese de incidência do } \\
\text { ICMS), não cumpriu o dever } \\
\text { instrumental consistente no transporte } \\
\text { dos bens acompanhados de documento } \\
\text { fiscal hábil (nota fiscal), tendo em } \\
\text { vista o disposto nos artigos } 113, \S \S 2^{\circ} \\
\text { e } 3^{\circ} \text {, e } 194 \text {, do CTN. }\end{array}$ & $\begin{array}{l}\text { Ainda que, em tese, o deslocamento } \\
\text { de bens do ativo imobilizado e de } \\
\text { material de uso e consumo entre } \\
\text { estabelecimentos de uma mesma } \\
\text { instituição financeira não configure } \\
\text { hipótese de incidência do ICMS, } \\
\text { compete ao Fisco Estadual averiguar a } \\
\text { veracidade da aludida operação, } \\
\text { sobressaindo a razoabilidade e } \\
\text { proporcionalidade da norma jurídica } \\
\text { que tão-somente exige que os bens da } \\
\text { pessoa jurídica sejam acompanhados } \\
\text { das respectivas notas fiscais. }\end{array}$ & REsp 1116792/PB & $24 / 11 / 2010$ \\
\hline 370 & $\begin{array}{l}\text { Questão referente à incidência ou não } \\
\text { do imposto sobre a renda em relação } \\
\text { às verbas decorrentes de indenização } \\
\text { por dano moral. }\end{array}$ & $\begin{array}{l}\text { Não incide Imposto de Renda sobre } \\
\text { verba percebida a título de dano } \\
\text { moral. }\end{array}$ & REsp 1152764/CE & $23 / 06 / 2010$ \\
\hline 371 & $\begin{array}{l}\text { Questão referente à obrigação de a } \\
\text { União ressarcir ex-congressistas, sem } \\
\text { direito à pensão, em relação às } \\
\text { importâncias recolhidas a título de } \\
\text { contribuição previdenciária ao } \\
\text { Instituto de Previdência dos } \\
\text { Congressistas - IPC, extinto pela Lei } \\
\text { 9.506/97. }\end{array}$ & $\begin{array}{l}\text { Há de se reconhecer o direito à } \\
\text { restituição de contribuições pagas ao } \\
\text { extinto Instituto de Previdência dos } \\
\text { Congressistas - IPC, fundo fechado de } \\
\text { previdência, visto que os segurados, } \\
\text { ex-contribuintes, após a extinção, } \\
\text { nenhum benefício receberão em } \\
\text { contrapartida, evitando-se, assim, o } \\
\text { enriquecimento ilícito da União, } \\
\text { sucessora nos direitos e obrigações do } \\
\text { IPC. }\end{array}$ & REsp 1122387/DF & $25 / 08 / 2010$ \\
\hline 372 & $\begin{array}{l}\text { Questão referente à possibilidade de } \\
\text { entidade hospitalar optar pelo } \\
\text { SIMPLES, em face da vedação } \\
\text { imposta pelo art. } 9^{\circ} \text {, IX, da Lei } \\
\text { 9.317/96. }\end{array}$ & $\begin{array}{l}\text { Os hospitais podem optar pelo } \\
\text { SIMPLES, tendo em vista que eles } \\
\text { não são prestadores de serviços } \\
\text { médicos e de enfermagem, mas, ao } \\
\text { contrário, dedicam-se a atividades que } \\
\text { dependem de profissionais que } \\
\text { prestem referidos serviços, uma vez } \\
\text { que há diferença entre a empresa que } \\
\text { presta serviços médicos e aquela que } \\
\text { contrata profissionais para a } \\
\text { consecução de sua finalidade. }\end{array}$ & REsp 1127564/PR & $09 / 08 / 2010$ \\
\hline 374 & $\begin{array}{l}\text { Discute-se a possibilidade de exclusão, } \\
\text { da base de cálculo do IPI, dos } \\
\text { descontos incondicionais concedidos } \\
\text { pelas fabricantes de bebidas às } \\
\text { empresas distribuidoras. }\end{array}$ & $\begin{array}{l}\text { A dedução dos descontos } \\
\text { incondicionais é vedada, no entanto, } \\
\text { quando a incidência do tributo se dá } \\
\text { sobre valor previamente fixado, nos } \\
\text { moldes da Lei } 7.798 / 89 \text { (regime de } \\
\text { preços fixos), salvo se o resultado } \\
\text { dessa operação for idêntico ao que se } \\
\text { chegaria com a incidência do imposto } \\
\text { sobre o valor efetivo da operação, } \\
\text { depois de realizadas as deduções } \\
\text { pertinentes. }\end{array}$ & REsp 1149424/BA & $28 / 04 / 2010$ \\
\hline
\end{tabular}


375 Questão referente à impossibilidade de revisão judicial da confissão de dívida, efetuada com o escopo de obter parcelamento de débitos tributários, quando o fundamento desse reexame judicial é relativo à situação fática

76 Questão referente à necessidade de intimação do agravado para responder ao recurso, nos termos do art. 527, I, do CPC. sobre a qual incide a norma tributária.

A confissão da dívida não inibe o questionamento judicial da obrigação tributária, no que se refere aos seus aspectos jurídicos. Quanto aos aspectos fáticos sobre os quais incide a norma tributária, a regra é que não se pode rever judicialmente a confissão de dívida efetuada com o escopo de obter parcelamento de débitos tributários. No entanto, como na situação presente, a matéria de fato constante de confissão de dívida pode ser invalidada quando ocorre defeito causador de nulidade do ato jurídico (v.g. erro, dolo, simulação e fraude).

A intimação da parte agravada para resposta é procedimento natural de preservação do princípio do contraditório, nos termos do art. 527, V, do CPC. (...) A dispensa do referido ato processual ocorre tãosomente quando o relator nega seguimento ao agravo (art. 527, I), uma vez que essa decisão beneficia o agravado, razão pela qual conclui-se que a intimação para a apresentação de contrarrazões é condição de validade da decisão que causa prejuízo ao recorrente.
377 Questão referente à necessidade de intimação do agravado para responder ao recurso, nos termos do art. 527, I, do CPC.

A intimação da parte agravada para resposta é procedimento natural de preservação do princípio do contraditório, nos termos do art. 527 , $\mathrm{V}$, do CPC. (...) A dispensa do referido ato processual ocorre tãosomente quando o relator nega seguimento ao agravo (art. 527, I), uma vez que essa decisão beneficia o agravado, razão pela qual conclui-se que a intimação para a apresentação de contrarrazões é condição de validade da decisão que causa prejuízo ao recorrente.

380 Discute-se a aplicação da multa de $10 \%$, prevista no caput do artigo 475 $\mathrm{J}$, do CPC, na hipótese em que o devedor, na fase de cumprimento de sentença ilíquida, efetua o depósito das quantias incontroversas e apresenta garantias referentes aos valores controvertidos, objeto de impugnação.

381 Questão referente à possibilidade ou não de aplicação das regras da imputação do pagamento, previstas no Código Civil, à compensação tributária, de modo que a amortização da dívida da Fazenda perante o contribuinte, mediante compensação, seja realizada primeiro sobre os juros e, somente após, sobre o principal do crédito.

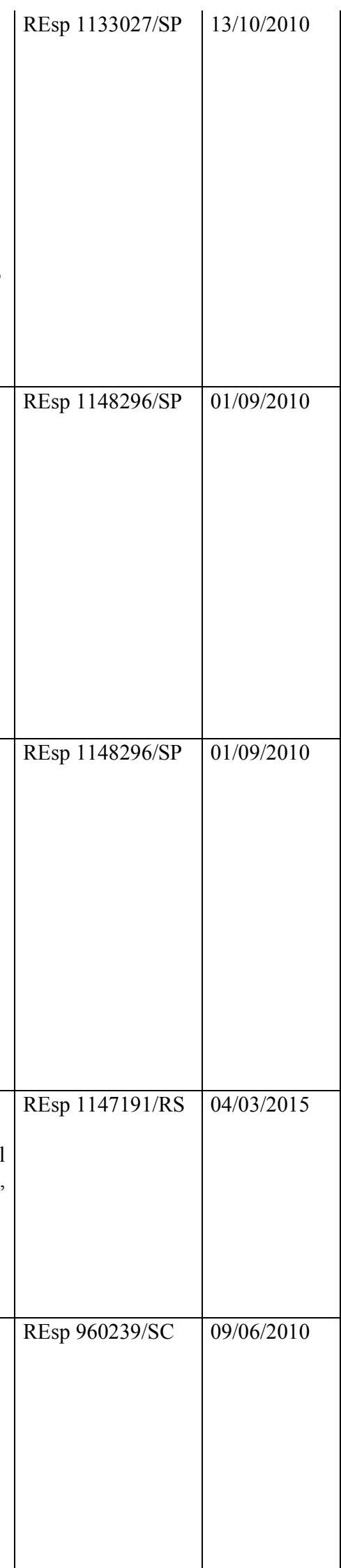


382 Questão referente à possibilidade ou não de extensão da responsabilidade tributária da empresa sucessora às multas, moratórias ou de outra espécie, aplicadas à empresa sucedida, e não apenas aos tributos por esta devidos.

383 Discute-se o termo inicial do prazo prescricional para o exercício da pretensão de cobrança judicial dos créditos tributários declarados pelo contribuinte (mediante DCTF ou GIA, entre outros), mas não pagos.
A responsabilidade tributária do sucessor abrange, além dos tributos devidos pelo sucedido, as multas moratórias ou punitivas, que, por representarem dívida de valor, acompanham o passivo do patrimônio adquirido pelo sucessor, desde que seu fato gerador tenha ocorrido até a data da sucessão.

O prazo prescricional quinquenal para

o Fisco exercer a pretensão de cobrança judicial do crédito tributário conta-se da data estipulada como vencimento para o pagamento da obrigação tributária declarada (mediante DCTF, GIA, entre outros), nos casos de tributos sujeitos a lançamento por homologação, em que, não obstante cumprido o dever instrumental de declaração da exação devida, não restou adimplida a obrigação principal (pagamento antecipado), nem sobreveio quaisquer das causas suspensivas da exigibilidade do crédito ou interruptivas do prazo prescricional.

384 Discute-se a legalidade ou não da recusa do fornecimento de Certidão Negativa de Débitos - CND ou Positiva com efeitos de Negativa CPD-EN ao contribuinte que, na seara administrativa, pleiteou a revisão de lançamento, fundado na alegação de pagamento integral do débito inscrito na dívida ativa, à luz do artigo 13 , da Lei 11.051/2004.

385 Discute-se a configuração de denúncia espontânea (artigo 138, do CTN) na hipótese em que o contribuinte, após efetuar a declaração parcial do débito tributário acompanhado do respectivo pagamento integral, retifica-a (antes de qualquer procedimento do fisco), noticiando a existência de diferença a maior, cuja quitação se dá concomitantemente.

387 Questão referente à alteração de dados cadastrais do imóvel não constitui erro de fato apto a ensejar a revisão do lançamento de IPTU, à luz do disposto nos artigos 146 e 149, do CTN.
A recusa, pela Administração

Fazendária Federal, do fornecimento de Certidão Positiva com efeitos de Negativa (CPD-EN), no período de 30.12.2004 a 30.12.2005, revela-se ilegítima na hipótese em que (trinta) dias do pedido de revisão administrativa formulado pelo contribuinte, fundado na alegação de pagamento integral do débito fiscal antes de sua inscrição na dívida ativa, ex vi do disposto no artigo 13, da Lei 11.051/2004.

\section{A denúncia espontânea resta} configurada na hipótese em que o contribuinte, após efetuar a declaração parcial do débito tributário (sujeito a lançamento por homologação) acompanhado do respectivo pagamento integral, retifica-a (antes de qualquer procedimento da Administração Tributária), noticiando a existência de diferença a maior, cuja quitação se dá concomitantemente. A retificação de dados cadastrais do imóvel, após a constituição do crédito tributário, autoriza a revisão do lançamento pela autoridade administrativa (desde que não extinto o direito potestativo da Fazenda Pública pelo decurso do prazo decadencial), quando decorrer da apreciação de fato não conhecido por ocasião do lançamento anterior, ex vi do disposto no artigo 149, inciso VIII, do CTN. configurada pendência superior a 30

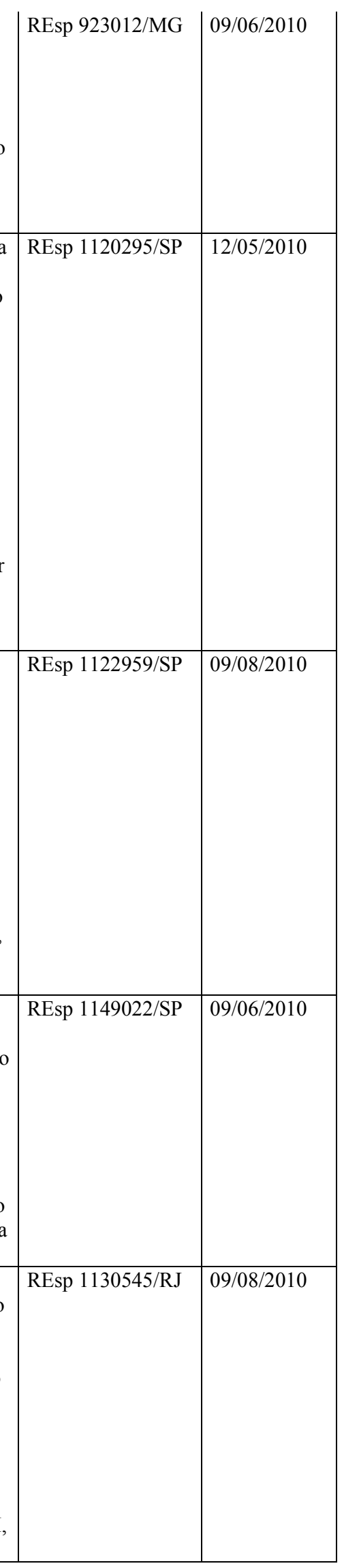


388 Discute-se a incidência ou não da CPMF (Contribuição Provisória sobre Movimentação ou Transmissão de Valores de Créditos e Direitos de natureza Financeira) sobre a conversão de crédito decorrente de empréstimo em investimento externo direto (contrato de câmbio simbólico).
389 Discute-se a responsabilidade tributária dos agentes marítimos representantes de transportadora, no que concerne ao Imposto de Importação.
A Contribuição Provisória sobre Movimentação ou Transmissão de Valores de Créditos e Direitos de Natureza Financeira - CPMF, enquanto vigente, incidia sobre a conversão de crédito decorrente de empréstimo em investimento externo direto (contrato de câmbio simbólico), uma vez que a tributação aperfeiçoava-se mesmo diante de operação unicamente escritural.

O agente marítimo, no exercício exclusivo de atribuições próprias, no período anterior à vigência do Decreto-Lei 2.472/88 (que alterou o artigo 32, do Decreto-Lei 37/66), não ostentava a condição de responsável tributário, nem se equiparava ao transportador, para fins de recolhimento do Imposto sobre Importação, porquanto inexistente previsão legal para tanto.

391 Discute-se a competência do juízo do inventário (arrolamento sumário) para apreciar pedido de reconhecimento de isenção do ITCMD (Imposto sobre Transmissão Causa Mortis e Doação de quaisquer Bens ou Direitos), à luz do disposto no artigo 179, do CTN.

392 Estabelecer se consubstancia uma faculdade do Juiz a reunião de processos contra o mesmo devedor por conveniência da unidade da garantia da execução, nos termos do art. 28 da Lei 6.830/80.

393 Questão referente à possibilidade ou não de, em concurso de credores, o crédito tributário de uma autarquia federal, in casu, o INSS, preferir os créditos da Fazenda Estadual, considerando-se a coexistência de execuções e penhoras, nos termos dos arts. 187, do CTN, e 29, da LEF.

394 Discute-se a legalidade dos arts. $7^{\circ} \mathrm{e}$ $8^{\circ}$ da Lei 8.541/1992 - Vedação à dedutibilidade para a apuração de base de cálculo de Imposto de Renda. Questão referente ao valor que representa 50 (cinqüenta) Obrigações Reajustáveis do Tesouro Nacional ORTN, à luz do disposto no artigo 34, da Lei n. $^{\circ} 6.830$, de 22 de setembro de 1980, para fins de alçada.

\section{O juízo do inventário, na modalidade} de arrolamento sumário, não detém competência para apreciar pedido de reconhecimento da isenção do ITCMD (Imposto sobre Transmissão Causa Mortis e Doação de quaisquer Bens ou Direitos), à luz do disposto no caput do artigo 179, do CTN. A reunião de processos contra $o$ mesmo devedor, por conveniência da unidade da garantia da execução, nos termos do art. 28 da Lei 6.830/80, é uma faculdade outorgada ao juiz, e não um dever.

O crédito tributário de autarquia federal goza do direito de preferência em relação àquele de que seja titular a Fazenda Estadual, desde que a penhora recaia sobre o mesmo bem.

Os depósitos judiciais utilizados para suspender a exigibilidade do crédito tributário consistem em ingressos tributários, sujeitos à sorte da demanda judicial, e não em receitas tributárias, de modo que não são dedutíveis da base de cálculo do IRPJ até o trânsito em julgado da demanda. Adota-se como valor de alçada para o cabimento de apelação em sede de execução fiscal o valor de R \$ 328,27 (trezentos e vinte e oito reais e vinte e sete centavos), corrigido pelo IPCA-E a partir de janeiro de 2001, valor esse que deve ser observado à data da propositura da execução.

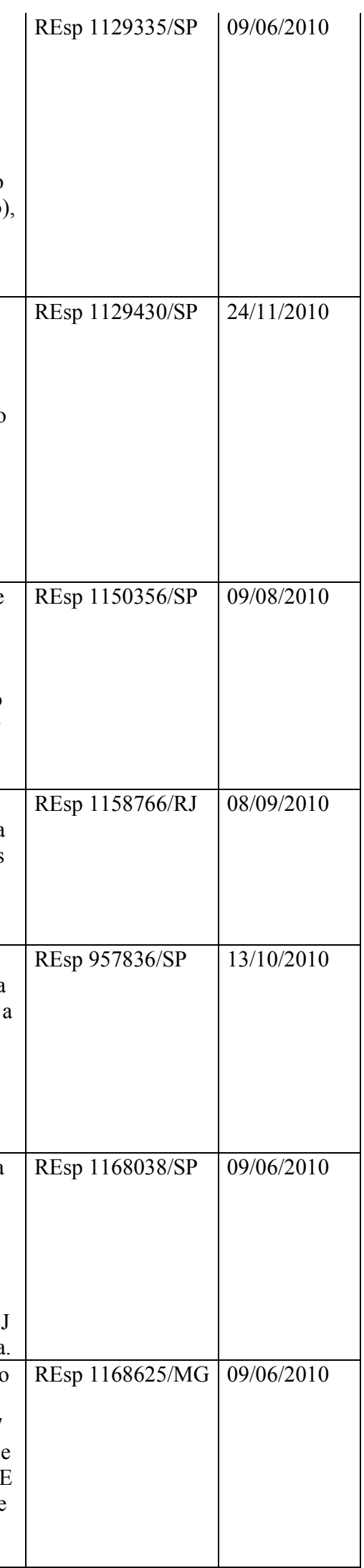


396 Discute-se a possibilidade de expedição de carta precatória de penhora e avaliação e conseqüente determinação de pagamento de custas e/ou despesas com o deslocamento do oficial de justiça estadual, no âmbito de execução fiscal ajuizada na Justiça Federal, à luz dos artigos 42 e 46, da Lei 5.010/66 e da Súmula 190/STJ.

397 Questão referente à não-incidência de Imposto de Renda sobre indenização decorrente de desapropriação, seja por necessidade ou utilidade pública ou por interesse social, porquanto não representa acréscimo patrimonial.
398 Questão referente à legitimidade da exigência da prova de ausência da repercussão financeira relativa ao ISS sobre locação de bens móveis, ou a autorização de quem a tenha assumido, nos termos do art. 166 do CTN, para fins de repetição de indébito.
Ainda que a execução fiscal tenha sido ajuizada na Justiça Federal (o que afasta a incidência da norma inserta no artigo $1^{\circ}, \S 1^{\circ}$, da Lei 9.289/96), cabe à Fazenda Pública Federal adiantar as despesas com o transporte/condução/deslocamento dos oficiais de justiça necessárias ao cumprimento da carta precatória de penhora e avaliação de bens (processada na Justiça Estadual), por força da princípio hermenêutico ubi eadem ratio ibi eadem legis dispositio. A indenização decorrente de desapropriação não encerra ganho de capital, porquanto a propriedade é transferida ao poder público por valor justo e determinado pela justiça a título de indenização, não ensejando lucro, mas mera reposição do valor do bem expropriado. (...) Não-incidência da exação sobre as verbas auferidas a título de indenização advinda de desapropriação, seja por necessidade ou utilidade pública ou por interesse social, porquanto não representam acréscimo patrimonial.

A pretensão repetitória de valores indevidamente recolhidos a título de ISS incidente sobre a locação de bens móveis (cilindros, máquinas e equipamentos utilizados para acondicionamento dos gases vendidos), hipótese em que o tributo assume natureza indireta, reclama da parte autora a prova da não repercussão, ou, na hipótese de ter a mesma transferido o encargo a terceiro, de estar autorizada por este a recebê-los.

399 Questão referente à incidência ou nãoincidência do ISS sobre os serviços prestados por empresas franqueadas dos Correios que realizam atividades postais e telemáticas.

Os serviços postais e telemáticos prestados por empresas franqueadas, sob a égide da LC 56/87, não sofrem a incidência do ISS, em observância ao princípio tributário da legalidade.

\section{A condenação, em honorários} advocatícios, do contribuinte, que formula pedido de desistência dos embargos à execução fiscal de créditos tributários da Fazenda Nacional, para fins de adesão a programa de parcelamento fiscal, configura inadmissível bis in idem, tendo em vista o encargo estipulado no Decreto-lei 1.025/69.

honorários advocatícios, a despeito do encargo legal de $20 \%$ previsto no Decreto-Lei 1.025/69.

401 Discute-se a legalidade da exclusão do contribuinte do programa de parcelamento - PAES, tão-somente em virtude da extemporaneidade do cumprimento do requisito da desistência de impugnação administrativa, na hipótese em que houve o deferimento tácito da adesão (não manifestação da autoridade fazendário no prazo de 90 dias - artigo

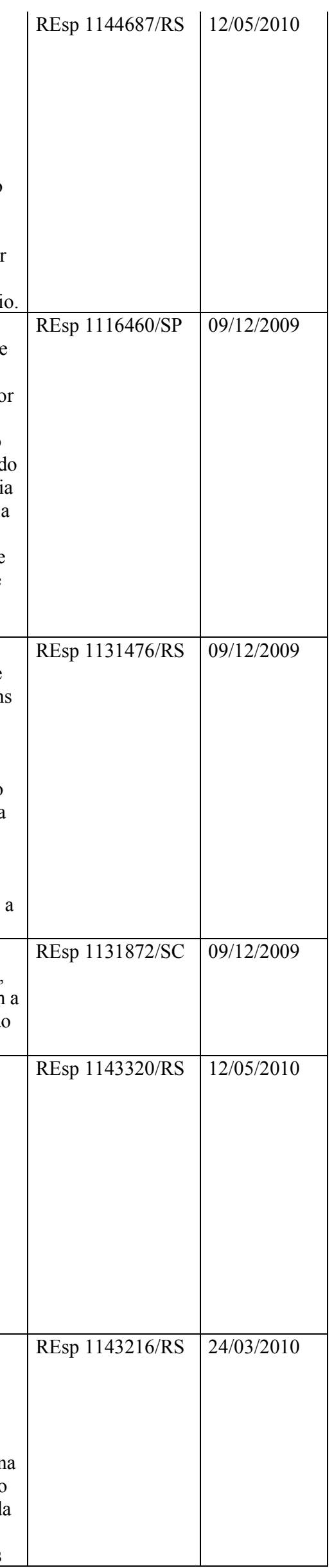




\begin{tabular}{|c|c|c|c|c|}
\hline & $\begin{array}{l}4^{\mathrm{o}}, \text { III, da Lei } 10.684 / 2003 \mathrm{c} / \mathrm{c} \text { artigo } \\
\left.11, \S 4^{\mathrm{o}} \text {, da Lei } 10.522 / 2002\right) \text { e o } \\
\text { efetivo pagamento das prestações } \\
\text { mensais estabelecidas. }\end{array}$ & $\begin{array}{l}\text { prestações mensais estabelecidas por } \\
\text { mais de quatro anos e sem qualquer } \\
\text { oposição do Fisco. }\end{array}$ & & \\
\hline 402 & $\begin{array}{l}\text { Discute-se a legitimidade da recusa do } \\
\text { fornecimento, pelo Fisco, de certidão } \\
\text { de regularidade fiscal (Certidão } \\
\text { Negativa de Débitos - CND), em } \\
\text { virtude da existência, por si só, de } \\
\text { apontada irregularidade em Guias de } \\
\text { Recolhimento do FGTS e Informações } \\
\text { à Previdência Social (GFIP's), a } \\
\text { despeito da ausência de lançamento de } \\
\text { ofício da suposta diferença constatada. }\end{array}$ & $\begin{array}{l}\text { Revela-se legítima a recusa da } \\
\text { autoridade impetrada em expedir } \\
\text { certidão negativa de débito (CND) ou } \\
\text { de certidão positiva com efeitos de } \\
\text { negativa (CPEN) quando a autoridade } \\
\text { tributária verifica a ocorrência de } \\
\text { pagamento a menor, em virtude da } \\
\text { existência de divergências entre os } \\
\text { valores declarados na Guia de } \\
\text { Recolhimento do FGTS e } \\
\text { Informações à Previdência Social } \\
\text { (GFIP) e os valores efetivamente } \\
\text { recolhidos mediante guia de } \\
\text { pagamento (GP). }\end{array}$ & REsp 1143094/SP & $09 / 12 / 2009$ \\
\hline 403 & $\begin{array}{l}\text { Questão referente à definição da base } \\
\text { de cálculo do ISS incidente sobre a } \\
\text { prestação de serviços de agenciamento } \\
\text { de mão-de-obra temporária. }\end{array}$ & $\begin{array}{l}\text { As empresas de mão-de-obra } \\
\text { temporária podem encartar-se em } \\
\text { duas situações, em razão da natureza } \\
\text { dos serviços prestados: (i) como } \\
\text { intermediária entre o contratante da } \\
\text { mão-de-obra e o terceiro que é } \\
\text { colocado no mercado de trabalho; (ii) } \\
\text { como prestadora do próprio serviço, } \\
\text { utilizando de empregados a ela } \\
\text { vinculados mediante contrato de } \\
\text { trabalho. A intermediação implica o } \\
\text { preço do serviço que é a comissão, } \\
\text { base de cálculo do fato gerador } \\
\text { consistente nessas "intermediações". } \\
\text { O ISS incide, nessa hipótese, apenas } \\
\text { sobre a taxa de agenciamento, que é o } \\
\text { preço do serviço pago ao agenciador, } \\
\text { sua comissão e sua receita, excluídas } \\
\text { as importâncias voltadas para o } \\
\text { pagamento dos salários e encargos } \\
\text { sociais dos trabalhadores. Distinção } \\
\text { de valores pertencentes a terceiros (os } \\
\text { empregados) e despesas com a } \\
\text { prestação. Distinção necessária entre } \\
\text { receita e entrada para fins financeiro- } \\
\text { tributários. }\end{array}$ & REsp 1138205/PR & $09 / 12 / 2009$ \\
\hline 404 & $\begin{array}{l}\text { Questão referente à definição da base } \\
\text { de cálculo do ISS incidente sobre a } \\
\text { prestação de serviços de agenciamento } \\
\text { de mão-de-obra temporária. }\end{array}$ & $\begin{array}{l}\text { As empresas de mão-de-obra } \\
\text { temporária podem encartar-se em } \\
\text { duas situações, em razão da natureza } \\
\text { dos serviços prestados: (i) como } \\
\text { intermediária entre o contratante da } \\
\text { mão-de-obra e o terceiro que é } \\
\text { colocado no mercado de trabalho; (ii) } \\
\text { como prestadora do próprio serviço, } \\
\text { utilizando de empregados a ela } \\
\text { vinculados mediante contrato de } \\
\text { trabalho. (...) Se a atividade de } \\
\text { prestação de serviço de mão-de-obra } \\
\text { temporária é prestada através de } \\
\text { pessoal contratado pelas empresas de } \\
\text { recrutamento, resta afastada a figura } \\
\text { da intermediação, considerando-se a } \\
\text { mão-de-obra empregada na prestação }\end{array}$ & REsp 1138205/PR & $09 / 12 / 2009$ \\
\hline
\end{tabular}




\begin{tabular}{|c|c|c|c|c|}
\hline & & $\begin{array}{l}\text { do serviço contratado como custo do } \\
\text { serviço, despesa não dedutível da base } \\
\text { de cálculo do ISS. }\end{array}$ & & \\
\hline 406 & $\begin{array}{l}\text { Discute-se a legalidade da cobrança } \\
\text { das contribuições para o Fundo de } \\
\text { Garantia por Tempo de Serviço - } \\
\text { FGTS, no período de } 1984 \text { a 1988, de } \\
\text { empresa dedicada a atividades } \\
\text { agroindustriais no setor sucro- } \\
\text { alcooleiro. }\end{array}$ & $\begin{array}{l}\text { Os empregados, que laboram no } \\
\text { cultivo da cana-de-açúcar para } \\
\text { empresa agroindustrial ligada ao setor } \\
\text { alcooleiro, detém a qualidade de } \\
\text { rurícola, o que traz como } \\
\text { consequência a isenção do FGTS } \\
\text { desde a edição da Lei Complementar } \\
\text { n. } 11 / 71 \text { até a promulgação da } \\
\text { Constituição Federal de } 1988 . \\
\end{array}$ & REsp 1133662/PE & $09 / 08 / 2010$ \\
\hline 407 & $\begin{array}{l}\text { Discussão acerca do cabimento de } \\
\text { honorários advocatícios em fase de } \\
\text { cumprimento de sentença, bem como } \\
\text { na sua impugnação, de acordo com a } \\
\text { sistemática processual introduzida pela } \\
\text { Lei }{ }^{\circ} 11.232 / 05 \text {. }\end{array}$ & $\begin{array}{l}\text { São cabíveis honorários advocatícios } \\
\text { em fase de cumprimento de sentença, } \\
\text { haja ou não impugnação, depois de } \\
\text { escoado o prazo para pagamento } \\
\text { voluntário a que alude o art. 475-J do } \\
\text { CPC, que somente se inicia após a } \\
\text { intimação do advogado, com a baixa } \\
\text { dos autos e a aposição do 'cumpra-se'. }\end{array}$ & REsp 1134186/RS & $01 / 08 / 2011$ \\
\hline 408 & $\begin{array}{l}\text { Discussão acerca do cabimento de } \\
\text { honorários advocatícios em fase de } \\
\text { cumprimento de sentença, bem como } \\
\text { na sua impugnação, de acordo com a } \\
\text { sistemática processual introduzida pela } \\
\text { Lei no } 11.232 / 05 \text {. } \\
\end{array}$ & $\begin{array}{l}\text { Não são cabíveis honorários } \\
\text { advocatícios pela rejeição da } \\
\text { impugnação ao cumprimento de } \\
\text { sentença. }\end{array}$ & REsp 1134186/RS & $01 / 08 / 2011$ \\
\hline 409 & $\begin{array}{l}\text { Discussão acerca do cabimento de } \\
\text { honorários advocatícios em fase de } \\
\text { cumprimento de sentença, bem como } \\
\text { na sua impugnação, de acordo com a } \\
\text { sistemática processual introduzida pela } \\
\text { Lei } n^{\circ} 11.232 / 05 \text {. }\end{array}$ & $\begin{array}{l}\text { Em caso de sucesso da impugnação, } \\
\text { com extinção do feito mediante } \\
\left.\text { sentença (art. } 475-\mathrm{M}, \S 3^{\circ}\right) \text {, revela-se } \\
\text { que quem deu causa ao procedimento } \\
\text { de cumprimento de sentença foi o } \\
\text { exequente, devendo ele arcar com as } \\
\text { verbas advocatícias. }\end{array}$ & REsp 1134186/RS & $01 / 08 / 2011$ \\
\hline 410 & $\begin{array}{l}\text { Discussão acerca do cabimento de } \\
\text { honorários advocatícios em fase de } \\
\text { cumprimento de sentença, bem como } \\
\text { na sua impugnação, de acordo com a } \\
\text { sistemática processual introduzida pela } \\
\text { Lei } \mathrm{n}^{\circ} 11.232 / 05 \text {. }\end{array}$ & $\begin{array}{l}\text { O acolhimento ainda que parcial da } \\
\text { impugnação gerará o arbitramento dos } \\
\text { honorários, que serão fixados nos } \\
\text { termos do art. } 20, \S 4^{\circ} \text {, do CPC, do } \\
\text { mesmo modo que o acolhimento } \\
\text { parcial da exceção de pré- } \\
\text { executividade, porquanto, nessa } \\
\text { hipótese, há extinção também parcial } \\
\text { da execução. }\end{array}$ & REsp 1134186/RS & $01 / 08 / 2011$ \\
\hline
\end{tabular}


411 Questiona a obrigação ou não de a instituição financeira exibir documentos (extratos bancários) comuns às partes.
É cabível a inversão do ônus da prova em favor do consumidor para o fim de determinar às instituições financeiras a exibição de extratos bancários, enquanto não estiver prescrita a eventual ação sobre eles, tratando-se de obrigação decorrente de lei e de integração contratual compulsória, não sujeita à recusa ou condicionantes, tais como o adiantamento dos custos da operação pelo correntista e a prévia recusa administrativa da instituição financeira em exibir os documentos, com a ressalva de que ao correntista, autor da ação, incumbe a

demonstração da plausibilidade da relação jurídica alegada, com indícios mínimos capazes de comprovar a existência da contratação, devendo, ainda, especificar, de modo preciso, os períodos em que pretenda ver exibidos os extratos.

412 Versa sobre a interpretação do art. $6^{\circ}$, parágrafo único, da Lei Complementar 7/1970. Discute-se, no caso, se tal dispositivo refere-se ao prazo para recolhimento do PIS ou à sua base de cálculo.

413 Discute-se a possibilidade de recolhimento das custas processuais em dia útil posterior, quando o agravo de instrumento tenha sido protocolado após o fim do horário de expediente das agências bancárias.

414 Discute-se a possibilidade de cobrança de tarifa mínima de água, com base no número de economias, sem considerar o consumo efetivamente registrado no único hidrômetro local.

415 Definir se a entrega de carnês de IPTU, diretamente por servidores municipais, violaria a exclusividade da Empresa Nacional de Correios e Telégrafos na prestação do serviço postal.

416 Discute-se a possibilidade de concessão de auxílio-acidente independe do grau da incapacidade, sendo de rigor o deferimento, ainda que mínima a redução da capacidade laborativa. manutenção do serviço público postal.
A base de cálculo do PIS, até a edição

da MP n. 1.212/1995, era o

faturamento ocorrido no sexto mês anterior ao do fato gerador.

\begin{tabular}{|c|c|}
\hline Admite-se que o preparo seja efetuado & REsp 1122064/DF \\
\hline
\end{tabular}
no primeiro dia útil subsequente, quando a interposição do recurso ocorrer após o encerramento do expediente bancário.

Não é lícita a cobrança de tarifa de água no valor do consumo mínimo multiplicado pelo número de economias existentes no imóvel, quando houver único hidrômetro no local. A cobrança pelo fornecimento de água aos condomínios em que o consumo total de água é medido por único hidrômetro deve se dar pelo consumo real aferido.

A entrega de carnês de IPTU pelos municípios, sem a intermediação de terceiros, no seu âmbito territorial, não viola o privilégio da União na

Exige-se, para concessão do auxílioacidente, a existência de lesão, decorrente de acidente do trabalho, que implique redução da capacidade para o labor habitualmente exercido. O nível do dano e, em consequência, o grau do maior esforço, não interferem na concessão do benefício, o qual será devido ainda que mínima a lesão.

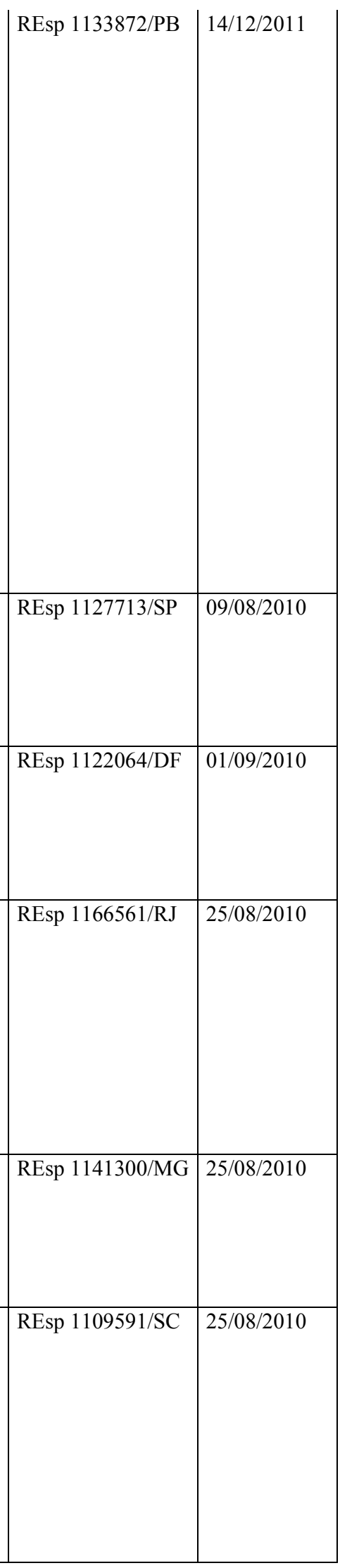


420 Cinge-se a discussão em saber se o art. 741, parágrafo único, do CPC, que criou hipótese de inexigibilidade do título judicial, pode ser alegado em embargos à execução propostos pela CEF para excluir percentuais de correção monetária e expurgos inflacionários considerados indevidos pelo Supremo, por meio de recurso extraordinário, para as contas vinculadas ao FGTS.

421 EXECUÇÃO FISCAL. EXCEÇÃO É possível a condenação da Fazenda DE PRÉ- EXECUTIVIDADE. CONDENAÇÃO EM HONORÁRIOS.

422 PREVIDENCIÁRIO. APOSENTADORIA. CONVERSÃO DE TEMPO DE SERVIÇO ESPECIAL EM COMUM. FATOR MULTIPLICADOR PREVISTO NA LEGISLAÇÃO EM VIGOR À ÉPOCA DA ATIVIDADE. TERMO FINAL PARA CONVERSÃO EM 28/5/1998. NECESSIDADE DE EXPOSIÇÃO PERMANENTE E HABITUAL. VIOLAÇÃO DOS ARTS. 57, § $3^{\circ}$, LEI N. 8.213/1991 E 63, I, DO DECRETO N. 611/1992. CONTAGEM DE TEMPO DE SERVIÇO POSTERIOR À EMENDA CONSTITUCIONAL N. 20/1998.

423 PREVIDENCIÁRIO. APOSENTADORIA. CONVERSÃO DE TEMPO DE SERVIÇO ESPECIAL EM COMUM. FATOR MULTIPLICADOR PREVISTO NA LEGISLAÇÃO EM VIGOR À ÉPOCA DA ATIVIDADE. TERMO FINAL PARA CONVERSÃO EM 28/5/1998. NECESSIDADE DE EXPOSIÇÃO PERMANENTE E HABITUAL. VIOLAÇÃO DOS ARTS. 57, $\S 3^{\circ}$, LEI N. 8.213/1991 E 63, I, DO DECRETO N. 611/1992. CONTAGEM DE TEMPO DE SERVIÇO POSTERIOR À EMENDA CONSTITUCIONAL N. 20/1998.

424 Discute-se a incidência do Imposto de Renda sobre o abono de permanência de que trata o $\S 19$ do art. 40 da Constituição Federal, acrescentado pela Emenda Constitucional 41/2003.

425 Discute-se a quebra do sigilo bancário em execução fiscal, por meio do sistema BACEN-JUD, viabilizadora do bloqueio de ativos financeiros do executado (Lei Complementar $105 / 2001)$.

A adoção deste ou daquele fator de conversão depende, tão somente, do tempo de contribuição total exigido em lei para a aposentadoria integral, ou seja, deve corresponder ao valor tomado como parâmetro, numa relação de proporcionalidade, o que corresponde a um mero cálculo matemático e não de regra previdenciária.
Sujeitam-se a incidência do Imposto de Renda os rendimentos recebidos a título de abono de permanência a que se referem o $\S 19$ do art. 40 da Constituição Federal, o $\S 5^{\circ}$ do art. $2^{\circ}$ e o $\S 1^{\circ}$ do art. $3^{\circ}$ da Emenda Constitucional 41/203, e o art. $7^{\circ}$ da Lei $10.887 / 2004$.

A utilização do Sistema BACENJUD, no período posterior à vacatio legis da Lei 11.382/2006

(21.01.2007), prescinde do exaurimento de diligências extrajudiciais, por parte do exequente, a fim de se autorizar o bloqueio eletrônico de depósitos ou aplicações financeiras. 
426 Questiona, no âmbito dos contratos de financiamento habitacional, a) a prática de anatocismo em decorrência da utilização do Sistema de Amortização Francês - "Tabela Price"; e b) a cobertura do saldo devedor pelo FCVS, na ausência de disposição contratual a respeito.

427 Questão referente à ilegitimidade da incidência do ICMS sobre serviços suplementares ao serviços de comunicação (atividade-meio), sob pena de violação ao princípio da tipicidade tributária.

30 Definir se o mandamus não pode ser impetrado contra lei em tese.

31 Discute-se o cabimento da retenção da contribuição previdenciária prevista no art. 16-A da Lei 10.887/2004, introduzido pela Medida Provisória $449 / 2008$, pois não prevista no título executivo.

432 Discute-se a legalidade da Instrução Normativa 23/97 que restringiu o direito ao crédito presumido do IPI às pessoas jurídicas efetivamente sujeitas à incidência da contribuição destinada ao PIS/PASEP e da COFINS, à luz do
Salvo disposição contratual em sentido diferente, aplica-se aos contratos celebrados no âmbito do Sistema Financeiro da Habitação a regra de imputação prevista no art. 354 do Código Civil de 2002, que reproduz o art. 993 do Código Civil de 1916 e foi adotada pela RD BNH $81 / 1969$.

A incidência do ICMS, no que se

refere à prestação dos serviços de comunicação, deve ser extraída da Constituição Federal e da LC 87/96, incidindo o tributo sobre os serviços de comunicação prestados de forma onerosa, através de qualquer meio, inclusive a geração, a emissão, a recepção, a transmissão, a retransmissão, a repetição e a ampliação de comunicação de qualquer natureza (art. $2^{\circ}$, III, da LC 87/96). A prestação de serviços conexos ao de comunicação por meio da telefonia móvel (que são preparatórios, acessórios ou intermediários da comunicação) não se confunde com a prestação da atividade fim processo de transmissão (emissão ou recepção) de informações de qualquer natureza, esta sim, passível de incidência pelo ICMS. Desse modo, a despeito de alguns deles serem essenciais à efetiva prestação do serviço de comunicação e admitirem a cobrança de tarifa pela prestadora do serviço (concessionária de serviço público), por assumirem o caráter de atividade meio, não constituem, efetivamente, serviços de comunicação, razão pela qual não é possível a incidência do ICMS.

No pertinente a impetração de ação mandamental contra lei em tese, a jurisprudência desta Corte Superior embora reconheça a possibilidade de mandado de segurança invocar a inconstitucionalidade da norma como fundamento para o pedido, não admite que a declaração de inconstitucionalidade, constitua, ela própria, pedido autônomo.

A retenção na fonte da contribuição do Plano de Seguridade do Servidor Público - PSS, incidente sobre valores pagos em cumprimento de decisão judicial, prevista no art. 16-A da Lei $10.887 / 04$, constitui obrigação ex lege e como tal deve ser promovida independentemente de condenação ou de prévia autorização no título executivo.

\begin{tabular}{|l|l|l|}
\hline O benefício fiscal do ressarcimento do & REsp 993164/MG & 13/12/2010
\end{tabular} crédito presumido do IPI relativo às exportações incide mesmo quando as matérias-primas ou os insumos sejam adquiridos de pessoa física ou jurídica não contribuinte do PIS/PASEP.

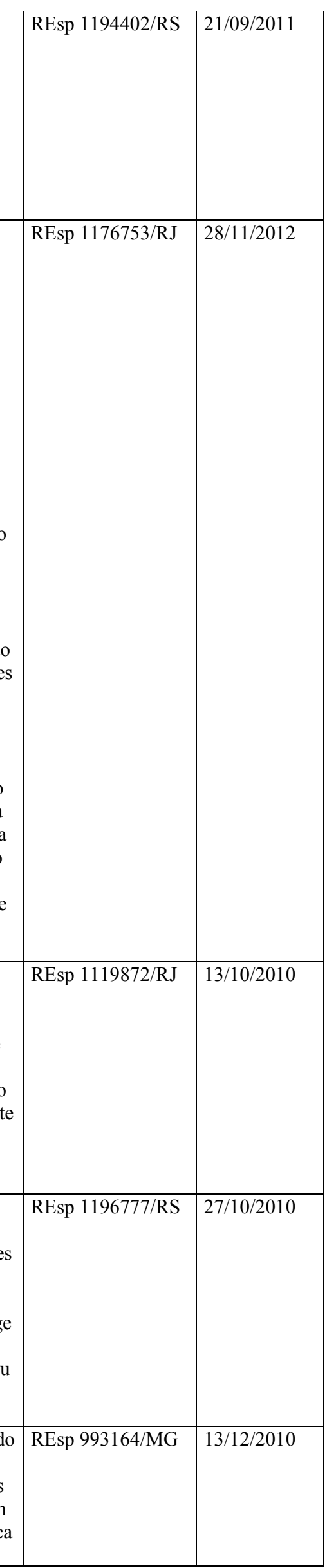




\begin{tabular}{|c|c|c|c|c|}
\hline & disposto na Lei 9.363/96. & & & \\
\hline 433 & $\begin{array}{l}\text { Sustenta a contrariedade ao disposto } \\
\text { no art. } 381 \text { do Código Civil de } 2002 \text {, } \\
\text { ao argumento de que não é cabível a } \\
\text { condenação de autarquia estadual ao } \\
\text { pagamento de honorários advocatícios } \\
\text { nas demandas patrocinadas pela } \\
\text { Defensoria Pública, por haver } \\
\text { confusão entre as qualidades de credor } \\
\text { e devedor. }\end{array}$ & $\begin{array}{l}\text { Não são devidos honorários } \\
\text { advocatícios à Defensoria Pública } \\
\text { quando ela atua contra pessoa jurídica } \\
\text { de direito público integrante da } \\
\text { mesma Fazenda Pública. }\end{array}$ & REsp 1199715/RJ & $16 / 02 / 2011$ \\
\hline 434 & $\begin{array}{l}\text { Discute-se a legitimidade da aplicação } \\
\text { da multa prevista no art. } 557, \S 2^{\circ} \text {, do } \\
\text { CPC, ao fundamento da necessidade } \\
\text { de esgotamento de instância para fins } \\
\text { de acesso às Cortes Superiores. }\end{array}$ & $\begin{array}{l}\text { O agravo interposto contra decisão } \\
\text { monocrática do Tribunal de origem, } \\
\text { com o objetivo de exaurir a instância } \\
\text { recursal ordinária, a fim de permitir a } \\
\text { interposição de recurso especial e do } \\
\text { extraordinário, não é manifestamente } \\
\text { inadmissível ou infundado, o que } \\
\text { torna inaplicável a multa prevista no } \\
\text { art. } 557, \S 2^{\circ} \text {, do Código de Processo } \\
\text { Civil. }\end{array}$ & REsp 1198108/RJ & $17 / 10 / 2012$ \\
\hline 435 & $\begin{array}{l}\text { Discute-se a contrariedade aos artigos } \\
4^{\circ}, \text { do Decreto-Lei n. } 1.564 / 77 \text { (arts. } \\
449 \text { e } 459 \text {, do RIR/80); art. } 19, \S 6^{\circ} \text {, do } \\
\text { Decreto-Lei n. } 1.598 / 77 \text { (acrescentado } \\
\text { pelo Decreto-Lei n. } 1.730 / 79 \text { ) e ao art. } \\
4^{\circ} \text {, do Decreto-Lei n. } 2.462 / 88 \text {. Alega } \\
\text { que o lançamento suplementar foi } \\
\text { calcado na legislação vigente segundo } \\
\text { a qual na utilização do incentivo fiscal } \\
\text { (depósito para reinvestimento) teria de } \\
\text { ser observado, além do limite de } 40 \% \\
\text { (quarenta por cento) do imposto } \\
\text { devido, também o limite de } 40 \% \\
\text { (quarenta por cento) do imposto } \\
\text { calculado sobre o lucro da exploração. }\end{array}$ & $\begin{array}{l}\text { O art. } 4^{\circ} \text {, do Decreto-Lei n. } 2.462 / 88, \\
\text { ao dispor que o benefício fiscal } \\
\text { denominado 'depósito para } \\
\text { reinvestimento' é de } 40 \% \text { (quarenta } \\
\text { por cento) sobre o valor do imposto } \\
\text { devido somado a outros } 40 \% \\
\text { (quarenta por cento) de recursos } \\
\text { próprios, não modificou a base de } \\
\text { cálculo do benefício fiscal, } \\
\text { permanecendo íntegra a exigência de } \\
\text { que o benefício deve ser calculado } \\
\text { com base no imposto de renda } \\
\text { incidente sobre o lucro da exploração } \\
\text { (art. } 19, \S 6^{\circ} \text {, do Decreto-Lei n. } \\
1.598 / 77, \text { incluído pelo Decreto-Lei n. } \\
1.730 / 79 \text { ). }\end{array}$ & REsp 1201850/PE & $24 / 11 / 2010$ \\
\hline 436 & $\begin{array}{l}\text { Discute-se a ilegitimidade ativa ad } \\
\text { causam em ação de indenização por } \\
\text { danos materiais e morais em razão de } \\
\text { acidente ambiental ocorrido no Porto } \\
\text { de Paranaguá com o navio N/T.Norma }\end{array}$ & $\begin{array}{l}\text { É parte legítima para ação de } \\
\text { indenização o pescador profissional } \\
\text { artesanal, com início de atividade } \\
\text { profissional registrada no } \\
\text { Departamento de Pesca e Agricultura } \\
\text { do Ministério da Agricultura e do } \\
\text { Abastecimento anteriormente ao fato, } \\
\text { ainda que a emissão da carteira de } \\
\text { pescador profissional tenha ocorrido } \\
\text { posteriormente. }\end{array}$ & REsp 1114398/PR & $08 / 02 / 2012$ \\
\hline 437 & $\begin{array}{l}\text { Discute-se o cerceamento de defesa } \\
\text { em decorrência do julgamento } \\
\text { antecipado da lide. }\end{array}$ & $\begin{array}{l}\text { Não configura cerceamento de defesa } \\
\text { o julgamento antecipado da lide, ante } \\
\text { os elementos documentais suficientes. }\end{array}$ & REsp 1114398/PR & $08 / 02 / 2012$ \\
\hline 438 & $\begin{array}{l}\text { Discute-se presença de culpa exclusiva } \\
\text { de terceiro como excludente de } \\
\text { responsabilidade, o que importaria na } \\
\text { não aplicação da teoria do risco } \\
\text { integral em acidente ambiental. }\end{array}$ & $\begin{array}{l}\text { A alegação de culpa exclusiva de } \\
\text { terceiro pelo acidente em causa, como } \\
\text { excludente de responsabilidade, deve } \\
\text { ser afastada, ante a incidência da } \\
\text { teoria do risco integral e da } \\
\text { responsabilidade objetiva ínsita ao } \\
\text { dano ambiental (art. } 225, \S 3^{\circ} \text {, da CF } \\
\text { e do art. } 14, \S 1^{\circ} \text {, da Lei } \mathrm{n}^{\circ} 6.938 / 81 \text { ), } \\
\text { responsabilizando o degradador em } \\
\text { decorrência do princípio do poluidor- } \\
\text { pagador. }\end{array}$ & REsp 1114398/PR & $08 / 02 / 2012$ \\
\hline
\end{tabular}


439 Discute-se a inexistência de dano moral em razão de acidente ambiental ocorrido no Porto de Paranaguá com o navio N/T Norma.

440 Discute o termo inicial da incidência dos juros moratórios para a reparação a título de danos morais e materias decorrentes de acidente ambiental.

441 Discute-se a distribuição do ônus da sucumbência de forma recíproca em em ação visando reparação decorrente de acidente ambiental.

442 Discute-se forma de amortização do saldo devedor do sistema financeiro de habitação.

443 Questiona a possibilidade de levantamento do depósito judicial, em execução provisória oriunda de ação de indenização por danos morais e materiais, no valor não excedente a 60 (sessenta) salários mínimos, sem a prestação de caução, nos termos do art. 475-O, III e $\S 2^{\circ}$, I, do CPC (situação de necessidade e créditos de natureza alimentar ou decorrentes de ato ilícito), mesmo havendo o risco de irreversibilidade da medida.

446 Questão referente à legítima a recusa do suspeito a soprar o etilômetro ou a fornecer sangue para a alcoolemia.

Discute-se o argumento de que a inclusão, efetivada pela Lei 11.705/08 ao artigo 306 do CTB, de concentração equivalente a 6 decigramas de álcool por litro de sangue, não significa, de forma alguma, abrandamento da norma penal. Cria, na realidade, apenas maior dificuldade para comprovação fática daquilo que se contêm na denúncia.
449 Discute-se a verificação da incidência da regra prevista no art. 26, II, do Código de Defesa do Consumidor, à ação de prestação de contas ajuizada pelo cliente de instituição financeira, visando a obter esclarecimentos acerca
É devida a indenização por dano moral patente o sofrimento intenso do pescador profissional artesanal, causado pela privação das condições de trabalho, em consequência do dano ambiental.

Os juros moratórios incidem a partir

da data do fato, no tocante aos valores devidos a título de dano material e moral.

A condenação em montante inferior ao postulado na inicial não afasta a sucumbência mínima, de modo que não se redistribuem os ônus da sucumbência.

Nos contratos vinculados ao SFH, a atualização do saldo devedor antecede sua amortização pelo pagamento da prestação. Súmula 450/STJ

É permitido ao juiz da execução, diante da natureza alimentar do crédito e do estado de necessidade dos exequentes, a dispensa da contracautela para o levantamento do crédito, limitado, contudo, a 60 (sessenta) vezes o salário mínimo.

\begin{tabular}{|l|l|l} 
O indivíduo não pode ser compelido a & REsp 1111566/DF & 28/03/2012
\end{tabular} colaborar com os referidos testes do 'bafômetro' ou do exame de sangue, em respeito ao princípio segundo o qual ninguém é obrigado a se autoincriminar (nemo tenetur se detegere).

O tipo penal do art. 306 do Código de Trânsito Brasileiro é formado, entre outros, por um elemento objetivo, de natureza exata, que não permite a aplicação de critérios subjetivos de interpretação, qual seja, o índice de 6 decigramas de álcool por litro de sangue. O grau de embriaguez é elementar objetiva do tipo, não configurando a conduta típica o exercício da atividade em qualquer outra concentração inferior àquela determinada pela lei, emanada do Congresso Nacional. O decreto regulamentador, podendo elencar quaisquer meios de prova que considerasse hábeis à tipicidade da conduta, tratou especificamente de 2 (dois) exames por métodos técnicos e científicos que poderiam ser realizados em aparelhos homologados pelo CONTRAN, quais sejam, o exame de sangue e o etilômetro.

A decadência do art. 26 do CDC não é REsp 1117614/PR

$10 / 08 / 2011$ aplicável à prestação de contas para obter esclarecimentos sobre cobrança de taxas, tarifas e encargos bancários.

\begin{tabular}{|l|l|} 
REsp 1114398/PR & $08 / 02 / 2012$ \\
\hline REsp 1114398/PR & $08 / 02 / 2012$ \\
\hline REsp 1114398/PR & $08 / 02 / 2012$ \\
\hline REsp 1110903/PR & $01 / 12 / 2010$ \\
\hline REsp 1145353/PR & $25 / 04 / 2012$
\end{tabular}

$\mathrm{R}$

REsp 1111566/DF

$28 / 03 / 2012$ 


\begin{tabular}{|c|c|c|c|c|}
\hline & $\begin{array}{l}\text { de lançamentos realizados em conta } \\
\text { corrente de sua titularidade, os quais } \\
\text { reputa indevidos. }\end{array}$ & & & \\
\hline 450 & $\begin{array}{l}\text { Havendo acordo com a Fazenda } \\
\text { Pública, mesmo extrajudicial e sem } \\
\text { participação do advogado, cada parte } \\
\text { arcará com os honorários advocatícios } \\
\text { devidos a seus respectivos patronos -, } \\
\text { não prevalece sobre o disposto no } § 4^{\circ} \\
\text { do art. } 24 \text { da Lei } 8.906 / 04 \text { (Estatuto da } \\
\text { Advocacia), norma especial que } \\
\text { assegura ao advogado o direito } \\
\text { autônomo a seus honorários quando } \\
\text { não participa do acordo celebrado. }\end{array}$ & $\begin{array}{l}\mathrm{O} \S 2^{\circ} \text { do art. } 6^{\circ} \text { da Lei n. 9.469/1997, } \\
\text { que obriga à repartição dos honorários } \\
\text { advocatícios, é inaplicável a acordos } \\
\text { ou transações celebrados em data } \\
\text { anterior à sua vigência. }\end{array}$ & REsp 1218508/MG & $16 / 03 / 2011$ \\
\hline 451 & $\begin{array}{l}\text { Discute-se a majoração da taxa de } \\
\text { ocupação de terreno de marinha pela } \\
\text { revisão dos valores dos imóveis } \\
\text { promovida pela SPU. }\end{array}$ & $\begin{array}{l}\text { No caso das taxas de ocupação dos } \\
\text { terrenos de marinha, é despiciendo } \\
\text { procedimento administrativo prévio } \\
\text { com participação dos administrados } \\
\text { interessados, bastando que a } \\
\text { Administração Pública siga as normas } \\
\text { do Decreto n. } 2.398 / 87 \text { no que tange à } \\
\text { matéria. }\end{array}$ & REsp 1150579/SC & $10 / 08 / 2011$ \\
\hline 452 & $\begin{array}{l}\text { Questiona a obrigação de reajuste da } \\
\text { remuneração dos servidores públicos } \\
\text { municipais, a partir de fevereiro/1995, } \\
\text { em conformidade com as Leis } \\
\text { Municipais } 10.668 / 88 \text { e } 10.722 / 89, \\
\text { decidiu que não há falar em violação à } \\
\text { coisa julgada na aplicação da Lei } \\
\text { Municipal } 12.397 / 97, \text { motivo pelo } \\
\text { qual manteve a decisão que declarara } \\
\text { cumprida tal obrigação. }\end{array}$ & $\begin{array}{l}\text { Na fase cognitiva, foi assegurado a } \\
\text { servidores do Município de São Paulo } \\
\text { reajuste de vencimentos, para o mês } \\
\text { de fevereiro de } 1995 \text {, com base nas } \\
\text { Leis } 10.668 / 88 \text { e } 10.722 / 89 \text {, sem } \\
\text { fixação de percentual. A discussão, na } \\
\text { fase de liquidação, a respeito dos } \\
\text { supervenientes reajustes concedidos } \\
\text { pela legislação municipal (Lei } \\
\text { 12.397/97) e seus reflexos no cálculo } \\
\text { do percentual devido e no } \\
\text { cumprimento da condenação imposta } \\
\text { envolve exclusivamente interpretação } \\
\text { e aplicação de direito local, } \\
\text { insuscetível de reexame por recurso } \\
\text { especial. Aplicação, por analogia, da } \\
\text { Súmula } 280 \text { do STF. }\end{array}$ & REsp 1217076/SP & $28 / 09 / 2011$ \\
\hline 453 & $\begin{array}{l}\text { Questão relativa à impossibilidade de } \\
\text { a empresa arrendante de veículo ser } \\
\text { responsabilizada por valores cobrados } \\
\text { pela municipalidade, relativos à } \\
\text { remoção, guarda e conservação de } \\
\text { veículo apreendido em decorrência do } \\
\text { cometimento de infrações pelo } \\
\text { arrendatário, tendo em vista a posterior } \\
\text { retomada da posse do bem ante a } \\
\text { efetivação de sua busca e apreensão } \\
\text { pelo arrendante. }\end{array}$ & $\begin{array}{l}\text { As despesas relativas à remoção, } \\
\text { guarda e conservação de veículo } \\
\text { apreendido no caso de arrendamento } \\
\text { mercantil, independentemente da } \\
\text { natureza da infração que deu origem à } \\
\text { apreensão do veículo e ainda que haja } \\
\text { posterior retomada da posse do bem } \\
\text { pelo arrendante, são da } \\
\text { responsabilidade do arrendatário, que } \\
\text { se equipara ao proprietário enquanto } \\
\text { em vigor o contrato de arrendamento } \\
\text { (cf. artigo } 4^{\circ} \text { da Resolução Contran } n^{\circ} \\
149 / 2003 \text { ). }\end{array}$ & REsp 1114406/SP & $27 / 04 / 2011$ \\
\hline 455 & $\begin{array}{l}\text { Discute-se a incidência ou não da } \\
\text { contribuição social destinada ao PIS } \\
\text { sobre juros sobre capital próprio, à luz } \\
\text { da Lei 9.718/98 (regime cumulativo de } \\
\text { tributação). }\end{array}$ & $\begin{array}{l}\text { Não incide PIS/COFINS sobre o JCP } \\
\text { recebido durante a vigência da Lei } \\
9.718 / 98 \text { até a edição das Leis } \\
10.637 / 02 \text { (cujo art. } 1^{\circ} \text {. entrou em } \\
\text { vigor a partir de } 01.12 .2002 \text { ) e } \\
10.833 / 03 \text {, tal como no caso dos } \\
\text { autos, que se refere apenas ao período } \\
\text { compreendido entre } 01.03 .1999 \text { e } \\
30.09 .2002 \text {. }\end{array}$ & REsp 1104184/RS & $29 / 02 / 2012$ \\
\hline
\end{tabular}


456 Discute-se o método para a aferição do valor de R\$10.000,00 (dez mil reais) para fins da concessão da remissão prevista no art. 14, da Lei n. 11.941/2009.

57 Discute-se o método para a aferição do valor de R\$10.000,00 (dez mil reais) para fins da concessão da remissão prevista no art. 14, da Lei n. $11.941 / 2009$.

59 Questão referente à possibilidade de a parte autora interpor recurso adesivo de decisão que, em pedido de indenização por danos morais, fixa o valor da condenação em patamar inferior ao pleiteado.
A Lei 11.941/2008 remite os débitos para com a Fazenda Nacional vencidos há cinco anos ou mais cujo valor total consolidado seja igual ou inferior a 10 mil reais. $\mathrm{O}$ valor-limite acima referido deve ser considerado por sujeito passivo, e separadamente apenas em relação à natureza dos créditos, nos termos dos incisos I a IV do art. 14.

A Lei 11.941/2008 remite os débitos para com a Fazenda Nacional vencidos há cinco anos ou mais cujo valor total consolidado seja igual ou inferior a 10 mil reais. Não pode o magistrado, de ofício, pronunciar a remissão, analisando isoladamente o valor cobrado em uma Execução Fiscal, sem questionar a Fazenda sobre a existência de outros débitos que somados impediriam o contribuinte de gozar do benefício. $\mathrm{O}$ recurso adesivo pode ser interposto pelo autor da demanda indenizatória, julgada procedente, quando arbitrado, a título de danos morais, valor inferior ao que era almejado, uma vez configurado o interesse recursal do demandante em ver majorada a condenação, hipótese caracterizadora de sucumbência material. poderes de mandatário ou em razão de
462 Discute-se a necessidade de juntada, no momento da interposição do agravo de instrumento previsto no artigo 522 do Código de Processo Civil, de peças necessárias à compreensão da controvérsia (art. 525, II, do CPC).

463 Discute-se a responsabilidade da instituição financeira que, recebendo título por endosso-mandato, leva-o indevidamente a protesto.

64 Discute-se a responsabilidade da instituição financeira que, recebendo título por endosso-mandato, leva-o indevidamente a protesto.

465 Discute-se a responsabilidade da instituição financeira que, recebendo título por endosso translativo, leva-o indevidamente a protesto.

No agravo do artigo 522 do CPC, entendendo o Julgador ausente peças necessárias para a compreensão da controvérsia, deverá ser indicado quais são elas, para que o recorrente complemente o instrumento.

Só responde por danos materiais e morais o endossatário que recebe título de crédito por endosso-mandato e o leva a protesto se extrapola os ato culposo próprio, como no caso de apontamento depois da ciência acerca do pagamento anterior ou da falta de higidez da cártula

Só responde por danos materiais e morais o endossatário que recebe título de crédito por endosso-mandato e o leva a protesto se extrapola os poderes de mandatário ou em razão de ato culposo próprio, como no caso de apontamento depois da ciência acerca do pagamento anterior ou da falta de higidez da cártula.

Responde pelos danos decorrentes de protesto indevido o endossatário que recebe por endosso translativo título de crédito contendo vício formal extrínseco ou intrínseco, ficando ressalvado seu direito de regresso contra os endossantes e avalistas.

466 Discute-se a responsabilidade civil de fornecedores de serviços ou produtos, por inclusão indevida do nome de consumidores em cadastros de proteção ao crédito, em decorrência de

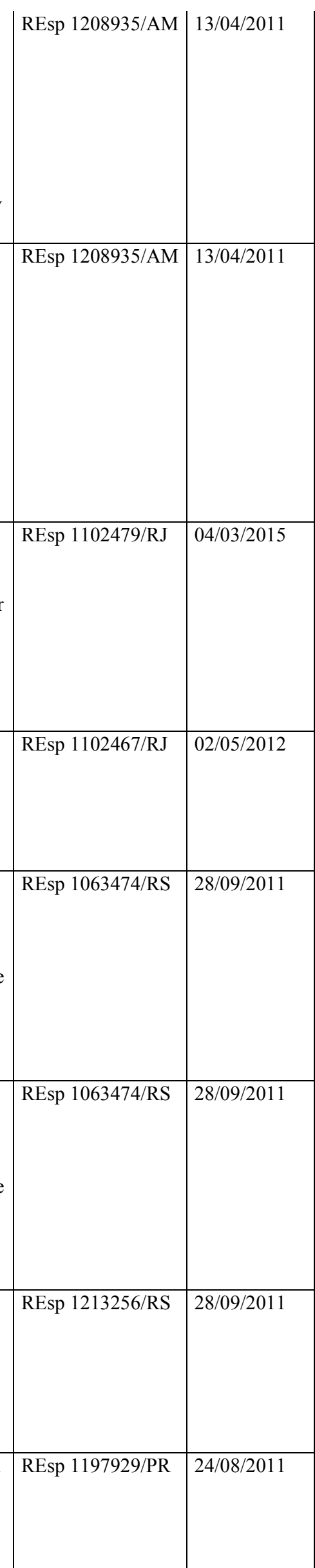




\begin{tabular}{|c|c|c|c|c|}
\hline & fraude praticada por terceiros. & & & \\
\hline 467 & $\begin{array}{l}\text { Questão referente ao cumprimento de } \\
\text { sentença proferida em ação } \\
\text { indenizatória ajuizada em face da } \\
\text { FLUMITRENS. Alegada ilegitimidade } \\
\text { passiva ad causam da SUPERVIA } \\
\text { CONCESSIONÁRIA DE } \\
\text { TRANSPORTE FERROVIÁRIO S/A. }\end{array}$ & $\begin{array}{l}\text { A concessão da exploração do serviço } \\
\text { de transporte ferroviário de } \\
\text { passageiros em favor da SUPERVIA, } \\
\text { mediante prévio procedimento } \\
\text { licitatório, não implicou sucessão } \\
\text { empresarial entre esta e a } \\
\text { FLUMITRENS. }\end{array}$ & REsp 1120620/RJ & $24 / 10 / 2012$ \\
\hline 468 & $\begin{array}{l}\text { Questão referente ao cumprimento de } \\
\text { sentença proferida em ação } \\
\text { indenizatória ajuizada em face da } \\
\text { FLUMITRENS. Alegada ilegitimidade } \\
\text { passiva ad causam da SUPERVIA } \\
\text { CONCESSIONÁRIA DE } \\
\text { TRANSPORTE FERROVIÁRIO S/A. }\end{array}$ & $\begin{array}{l}\text { A SUPERVIA não tem legitimidade } \\
\text { para responder por ilícitos praticados } \\
\text { pela FLUMITRENS à época em que } \\
\text { operava o serviço de transporte } \\
\text { ferroviário de passageiros. }\end{array}$ & REsp 1120620/RJ & $24 / 10 / 2012$ \\
\hline 469 & $\begin{array}{l}\text { Discute-se a possibilidade de } \\
\text { condenação solidária de seguradora } \\
\text { que foi litisdenunciada pelo segurado, } \\
\text { causador de danos a terceiros, em ação } \\
\text { de indenização por este ajuizada. }\end{array}$ & $\begin{array}{l}\text { Em ação de reparação de danos } \\
\text { movida em face do segurado, a } \\
\text { Seguradora denunciada pode ser } \\
\text { condenada direta e solidariamente } \\
\text { junto com este a pagar a indenização } \\
\text { devida à vítima, nos limites } \\
\text { contratados na apólice. }\end{array}$ & REsp 925130/SP & $08 / 02 / 2012$ \\
\hline 470 & $\begin{array}{l}\text { Discute-se a tributação pelo Imposto } \\
\text { de Renda dos juros de mora recebidos } \\
\text { como consectários de sentença } \\
\text { condenatória em reclamatória } \\
\text { trabalhista. }\end{array}$ & $\begin{array}{l}\text { Não incide Imposto de Renda sobre } \\
\text { os juros moratórios legais vinculados } \\
\text { a verbas trabalhistas reconhecidas em } \\
\text { decisão judicial. }\end{array}$ & REsp 1227133/RS & $28 / 09 / 2011$ \\
\hline 471 & $\begin{array}{l}\text { Questão referente à possibilidade de a } \\
\text { vítima de sinistro ajuizar ação } \\
\text { indenizatória diretamente contra a } \\
\text { seguradora do pretenso causador do } \\
\text { dano, ainda que não tenha feito parte } \\
\text { do contrato de seguro. }\end{array}$ & $\begin{array}{l}\text { Descabe ação do terceiro prejudicado } \\
\text { ajuizada direta e exclusivamente em } \\
\text { face da Seguradora do apontado } \\
\text { causador do dano. No seguro de } \\
\text { responsabilidade civil facultativo a } \\
\text { obrigação da Seguradora de ressarcir } \\
\text { danos sofridos por terceiros pressupõe } \\
\text { a responsabilidade civil do segurado, } \\
\text { a qual, de regra, não poderá ser } \\
\text { reconhecida em demanda na qual este } \\
\text { não interveio, sob pena de vulneração } \\
\text { do devido processo legal e da ampla } \\
\text { defesa. }\end{array}$ & REsp 962230/RS & $08 / 02 / 2012$ \\
\hline 472 & $\begin{array}{l}\text { Discute-se a necessidade da prévia } \\
\text { avaliação do imóvel para apuração do } \\
\text { valor da justa indenização para a } \\
\text { concessão de imissão provisória em } \\
\text { ação de desapropriação por utilidade } \\
\text { pública em caráter e regime de } \\
\text { urgência. }\end{array}$ & $\begin{array}{l}\text { O depósito judicial do valor } \\
\text { simplesmente apurado pelo corpo } \\
\text { técnico do ente público, sendo inferior } \\
\text { ao valor arbitrado por perito judicial e } \\
\text { ao valor cadastral do imóvel, não } \\
\text { viabiliza a imissão provisória na } \\
\text { posse. }\end{array}$ & REsp 1185583/SP & $27 / 06 / 2012$ \\
\hline 473 & $\begin{array}{l}\text { Questiona se a complementação de } \\
\text { aposentadoria ou pensão de ex- } \\
\text { ferroviário deveria, em razão do } \\
\text { princípio tempus regit actum, observar } \\
\text { a legislação previdenciária aplicável à } \\
\text { concessão do benefício - art. } 41 \text { do } \\
\text { Decreto } 83.080 / 79 \text {, que estabelecia } \\
\text { que a importância da pensão devida ao } \\
\text { conjunto dos dependentes do segurado } \\
\text { seria constituída de uma parcela } \\
\text { familiar, igual a } 50 \% \text { do valor da } \\
\text { aposentadoria que o segurado } \\
\text { percebida ou daquela a que teria } \\
\text { direito se na data do seu falecimento } \\
\text { fosse aposentado, e mais tantas } \\
\text { parcelas de } 10 \% \text { para cada dependente }\end{array}$ & $\begin{array}{l}\mathrm{O} \text { art. } 5^{\circ} \text { da Lei } 8.186 / 91 \text { assegura o } \\
\text { direito à complementação à pensão, } \\
\text { na medida em que determina a } \\
\text { observância das disposições do } \\
\text { parágrafo único do art. } 2^{\circ} \text { da citada } \\
\text { norma, o qual, de sua parte, garante a } \\
\text { permanente igualdade de valores entre } \\
\text { ativos e inativos. }\end{array}$ & REsp 1211676/RN & $08 / 08 / 2012$ \\
\hline
\end{tabular}




\begin{tabular}{|c|c|c|c|c|}
\hline & $\begin{array}{l}\text { segurado, até o máximo de } 5 \text { (cinco) } \\
\text { parcelas. }\end{array}$ & & & \\
\hline 474 & $\begin{array}{l}\text { Questiona a aplicação extensiva do } \\
\text { óbice da Súmula } 247 / \mathrm{STJ} \text { aos } \\
\text { contratos de mútuo imobiliário. }\end{array}$ & $\begin{array}{l}\text { A petição inicial da ação monitória } \\
\text { para cobrança de soma em dinheiro } \\
\text { deve ser instruída com demonstrativo } \\
\text { de débito atualizado até a data do } \\
\text { ajuizamento, assegurando-se, na sua } \\
\text { ausência ou insuficiência, o direito da } \\
\text { parte de supri-la, nos termos do art. } \\
284 \text { do CPC. }\end{array}$ & REsp 1154730/PE & $08 / 04 / 2015$ \\
\hline 475 & $\begin{array}{l}\text { Cinge-se a discussão em saber se, } \\
\text { julgados procedentes em parte os } \\
\text { embargos à execução para autorizar } \\
\text { que o reajuste de } 28,86 \% \text { nos } \\
\text { vencimentos dos servidores públicos o } \\
\text { montante obtido pode ser compensado } \\
\text { com aumentos concedidos } \\
\text { administrativamente, sem qualquer } \\
\text { previsão no título executivo judicial, } \\
\text { viola ou não a coisa julgada. }\end{array}$ & $\begin{array}{l}\text { Tratando-se de processo de } \\
\text { conhecimento, é devida a } \\
\text { compensação do índice de } 28,86 \% \\
\text { com os reajustes concedidos por essas } \\
\text { leis. }\end{array}$ & REsp 1235513/AL & $27 / 06 / 2012$ \\
\hline 476 & $\begin{array}{l}\text { Cinge-se a discussão em saber se, } \\
\text { julgados procedentes em parte os } \\
\text { embargos à execução para autorizar } \\
\text { que o reajuste de } 28,86 \% \text { nos } \\
\text { vencimentos dos servidores públicos o } \\
\text { montante obtido pode ser compensado } \\
\text { com aumentos concedidos } \\
\text { administrativamente, sem qualquer } \\
\text { previsão no título executivo judicial, } \\
\text { viola ou não a coisa julgada. }\end{array}$ & $\begin{array}{l}\text { Transitado em julgado o título judicial } \\
\text { sem qualquer limitação ao pagamento } \\
\text { integral do índice de } 28,86 \% \text {, não } \\
\text { cabe à União e às autarquias federais } \\
\text { alegar, por meio de embargos, a } \\
\text { compensação com tais reajustes, sob } \\
\text { pena de ofender-se a coisa julgada. }\end{array}$ & REsp 1235513/AL & $27 / 06 / 2012$ \\
\hline 477 & $\begin{array}{l}\text { Cinge-se a discussão em saber se ao } \\
\text { servidor aposentado do extinto DNER, } \\
\text { que passou a integrar os quadros do } \\
\text { Ministério dos Transportes, deve, ou } \\
\text { não, ter assegurada a extensão do } \\
\text { reajuste remuneratório previsto na Lei } \\
11.171 / 05 \text { para os servidores ativos do } \\
\text { DNIT. }\end{array}$ & $\begin{array}{l}\text { O servidor aposentado do extinto } \\
\text { DNER, ainda que passe a integrar o } \\
\text { quadro de inativos do Ministério dos } \\
\text { Transportes, deve ter como parâmetro } \\
\text { de seus proventos a retribuição dos } \\
\text { servidores ativos do DNER } \\
\text { absorvidos pelo DNIT, pois esta } \\
\text { autarquia é que é a sucessora do } \\
\text { DNER, não havendo razão jurídica } \\
\text { para justificar qualquer disparidade. }\end{array}$ & REsp 1244632/CE & $10 / 08 / 2011$ \\
\hline 482 & $\begin{array}{l}\text { Discute-se o foro competente para a } \\
\text { liquidação individual de sentença } \\
\text { proferida em ação civil pública. }\end{array}$ & $\begin{array}{l}\text { A sentença genérica prolatada no } \\
\text { âmbito da ação civil coletiva, por si, } \\
\text { não confere ao vencido o atributo de } \\
\text { devedor de 'quantia certa ou já fixada } \\
\text { em liquidação' (art. } 475-J \text { do CPC), } \\
\text { porquanto, 'em caso de procedência } \\
\text { do pedido, a condenação será } \\
\text { genérica', apenas 'fixando a } \\
\text { responsabilidade do réu pelos danos } \\
\text { causados' (art. } 95 \text { do CDC). A } \\
\text { condenação, pois, não se reveste de } \\
\text { liquidez necessária ao cumprimento } \\
\text { espontâneo do comando sentencial, } \\
\text { não sendo aplicável a reprimenda } \\
\text { prevista no art. } 475-J \text { do CPC. }\end{array}$ & REsp 1247150/PR & $19 / 10 / 2011$ \\
\hline
\end{tabular}


483 Demanda relativa à necessidade, ou não, nos termos da legislação vigente, da atuação de farmacêutico em dispensário de medicamentos, mantido por clínica e/ou unidades hospitalares, negou provimento ao recurso de apelação do recorrente.

484 Discussão sobre a possibilidade de retenção de valor a ser restituído/ressarcido quando o contribuinte manifesta a sua discordância em procedimento de compensação de ofício previsto no art. 73 , da lei n. $9.430 / 96$ e art. $7^{\circ}$, do decreto-lei n. 2.287/86.

485 Discussão sobre a possibilidade de pagamento mediante a transformação em pagamento definitivo (conversão em renda) de depósitos judiciais vinculados a ações já transitadas em julgado. Discute-se ainda sobre a possibilidade de devolução da diferença de juros selic incidentes sobre o valor depositado.
Não é obrigatória a presença de farmacêutico em dispensário de medicamentos.

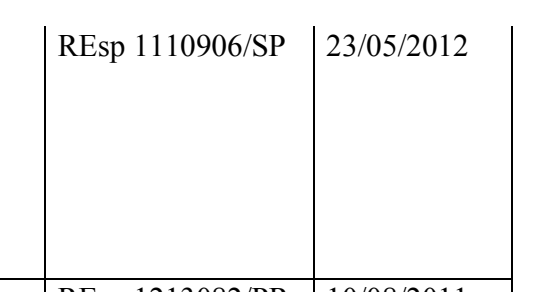

Fora dos casos previstos no art. 151, do CTN, a compensação de ofício é ato vinculado da Fazenda Pública Federal a que deve se submeter o sujeito passivo, inclusive sendo lícitos os procedimentos de concordância tácita e retenção previstos nos $\S \S 1^{\circ} \mathrm{e}$ $3^{\circ}$, do art. $6^{\circ}$, do Decreto n. 2.138/97. De acordo com o art. 156, I, do CTN, o pagamento extingue o crédito tributário. Se o pagamento por parte do contribuinte ou a transformação do depósito em pagamento definitivo por ordem judicial (art. $1^{\circ}, \S 3^{\circ}$, II, da Lei n. 9.703/98) somente ocorre depois de encerrada a lide, o crédito tributário tem vida após o trânsito em julgado que o confirma. Se tem vida, pode ser objeto de remissão e/ou anistia neste ínterim (entre o trânsito em julgado e a ordem para transformação em pagamento definitivo, antiga conversão em renda) quando a lei não exclui expressamente tal situação do seu âmbito de incidência.

486 Discussão sobre a possibilidade de pagamento mediante a transformação em pagamento definitivo (conversão em renda) de depósitos judiciais vinculados a ações já transitadas em julgado. Discute-se ainda sobre a possibilidade de devolução da diferença de juros selic incidentes sobre o valor depositado.

487 Discussão sobre a possibilidade de pagamento mediante a transformação em pagamento definitivo (conversão em renda) de depósitos judiciais vinculados a ações já transitadas em julgado. Discute-se ainda sobre a possibilidade de devolução da diferença de juros selic incidentes sobre o valor depositado.

488 Discussão sobre a possibilidade de pagamento mediante a transformação em pagamento definitivo (conversão em renda) de depósitos judiciais vinculados a ações já transitadas em julgado. Discute-se ainda sobre a possibilidade de devolução da diferença de juros selic incidentes sobre o valor depositado.

489 Discussão sobre a possibilidade de pagamento mediante a transformação em pagamento definitivo (conversão em renda) de depósitos judiciais vinculados a ações já transitadas em julgado. Discute-se ainda sobre a possibilidade de devolução da diferença de juros selic incidentes
A remissão/anistia das rubricas concedida (multa, juros de mora, encargo legal) somente incide se efetivamente existirem tais rubricas (saldos devedores) dentro da composição do crédito tributário cuja exigibilidade se encontra suspensa pelo depósito.

A remissão/anistia das rubricas concedida (multa, juros de mora, encargo legal) somente incide se efetivamente existirem tais rubricas composição do crédito tributário cuja exigibilidade se encontra suspensa pelo depósito.

A remissão/anistia das rubricas concedida (multa, juros de mora, encargo legal) somente incide se efetivamente existirem tais rubricas (saldos devedores) dentro da composição do crédito tributário cuja exigibilidade se encontra suspensa pelo depósito.

\section{A remissão/anistia das rubricas} concedida (multa, juros de mora, encargo legal) somente incide se efetivamente existirem tais rubricas (saldos devedores) dentro da composição do crédito tributário cuja exigibilidade se encontra suspensa pelo depósito. (saldos devedores) dentro da

\begin{tabular}{|l|l|}
\hline REsp 1213082/PR & $10 / 08 / 2011$ \\
\hline REsp 1251513/PR & $10 / 08 / 2011$ \\
\hline REsp 1251513/PR & $10 / 08 / 2011$ \\
\hline REsp 1251513/PR & $10 / 08 / 2011$ \\
& \\
& \\
& \\
& \\
& \\
& \\
& \\
\hline
\end{tabular}




\begin{tabular}{|c|c|c|c|c|}
\hline & sobre o valor depositado. & & & \\
\hline 490 & $\begin{array}{l}\text { Discussão sobre a possibilidade de } \\
\text { pagamento mediante a transformação } \\
\text { em pagamento definitivo (conversão } \\
\text { em renda) de depósitos judiciais } \\
\text { vinculados a ações já transitadas em } \\
\text { julgado. Discute-se ainda sobre a } \\
\text { possibilidade de devolução da } \\
\text { diferença de juros selic incidentes } \\
\text { sobre o valor depositado. }\end{array}$ & $\begin{array}{l}\text { A remissão de juros de mora insertos } \\
\text { dentro da composição do crédito } \\
\text { tributário não enseja o resgate de } \\
\text { juros remuneratórios incidentes sobre } \\
\text { o depósito judicial feito para } \\
\text { suspender a exigibilidade desse } \\
\text { mesmo crédito tributário. }\end{array}$ & REsp 1251513/PR & $10 / 08 / 2011$ \\
\hline 493 & $\begin{array}{l}\text { Hospital conveniado ao SUS. Tabelas } \\
\text { de preços. Fator de conversão em } \\
\text { URV. Competência. Prescrição. }\end{array}$ & $\begin{array}{l}\text { Nas demandas que envolvem a } \\
\text { discussão sobre a conversão da tabela } \\
\text { de ressarcimentos de serviços } \\
\text { prestados ao Sistema Único de Saúde } \\
\text { - SUS de cruzeiro real para real, (...) } \\
\text { por se tratar de relação de trato } \\
\text { sucessivo, prescrevem apenas as } \\
\text { parcelas vencidas anteriormente ao } \\
\text { quinquênio que antecedeu ao } \\
\text { ajuizamento da ação (Súmula } \\
\text { 85/STJ). }\end{array}$ & REsp 1179057/AL & $12 / 09 / 2012$ \\
\hline 494 & $\begin{array}{l}\text { Hospital conveniado ao SUS. Tabelas } \\
\text { de preços. Fator de conversão em } \\
\text { URV. Competência. Prescrição. }\end{array}$ & $\begin{array}{l}\text { Nas demandas que envolvem a } \\
\text { discussão sobre a conversão da tabela } \\
\text { de ressarcimentos de serviços } \\
\text { prestados ao Sistema Único de Saúde } \\
\text { - SUS de cruzeiro real para real, (...) } \\
\text { deve ser adotado como fator de } \\
\text { conversão o Valor de Cr } \$ 2.750,00 \text {, } \\
\text { nos termos do art. } 1^{\circ} \text {, } 3^{\circ} \text {, da MP } \\
542 / 95 \text {, convertida na Lei } 9.096 / 95 \text {. }\end{array}$ & REsp 1179057/AL & $12 / 09 / 2012$ \\
\hline 495 & $\begin{array}{l}\text { Hospital conveniado ao SUS. Tabelas } \\
\text { de preços. Fator de conversão em } \\
\text { URV. Competência. Prescrição. }\end{array}$ & $\begin{array}{l}\text { Nas demandas que envolvem a } \\
\text { discussão sobre a conversão da tabela } \\
\text { de ressarcimentos de serviços } \\
\text { prestados ao Sistema Único de Saúde } \\
\text { - SUS de cruzeiro real para real, (...) o } \\
\text { índice de } 9,56 \% \text {, decorrente da } \\
\text { errônea conversão em real, somente é } \\
\text { devido até } 1^{\circ} \text { de outubro de } 1999 \text {, data } \\
\text { do início dos efeitos financeiros da } \\
\text { Portaria } 1.323 / 99 \text {, que estabeleceu } \\
\text { novos valores para todos os } \\
\text { procedimentos. }\end{array}$ & REsp 1179057/AL & $12 / 09 / 2012$ \\
\hline 496 & $\begin{array}{l}\text { Discute a exigibilidade da } \\
\text { contribuição para o SESC e SENAC } \\
\text { por empresa prestadora de serviços } \\
\text { educacionais. } \\
\end{array}$ & $\begin{array}{l}\text { As empresas prestadoras de serviços } \\
\text { estão sujeitas às contribuições ao Sesc } \\
\text { e Senac, salvo se integradas noutro } \\
\text { serviço social. }\end{array}$ & REsp 1255433/SE & $23 / 05 / 2012$ \\
\hline 499 & $\begin{array}{l}\text { Questão referente à aplicação do artigo } \\
42 \text { do Decreto } \mathrm{n}^{\circ} 70.951 / 72 \text { quanto ao } \\
\text { limite do percentual da taxa de } \\
\text { administração cobrado pelas } \\
\text { administradoras de consórcio. }\end{array}$ & $\begin{array}{l}\text { As administradoras de consórcio têm } \\
\text { liberdade para fixar a respectiva taxa } \\
\text { de administração, nos termos do art. } \\
33 \text { da Lei } \mathrm{n}^{\circ} 8.177 / 91 \text { e da Circular } \mathrm{n}^{\circ} \\
2.766 / 97 \text { do Banco Central, não } \\
\text { havendo falar em ilegalidade ou } \\
\text { abusividade da taxa contratada } \\
\text { superior a } 10 \% \text { (dez por cento). }\end{array}$ & REsp 1114604/PR & $13 / 06 / 2012$ \\
\hline 500 & $\begin{array}{l}\text { Questão referente à obrigação do } \\
\text { arrendador devolver as quantias pagas } \\
\text { antecipadamente a título de Valor } \\
\text { Residual Garantido - VRG, nos caos } \\
\text { em que o produto objeto do leasing for } \\
\text { apreendido. }\end{array}$ & $\begin{array}{l}\text { Nas ações de reintegração de posse } \\
\text { motivadas por inadimplemento de } \\
\text { arrendamento mercantil financeiro, } \\
\text { quando o produto da soma do VRG } \\
\text { quitado com o valor da venda do bem } \\
\text { for maior que o total pactuado como } \\
\text { VRG na contratação, será direito do } \\
\text { arrendatário receber a diferença, }\end{array}$ & REsp 1099212/RJ & $27 / 02 / 2013$ \\
\hline
\end{tabular}




\begin{tabular}{|c|c|c|c|c|}
\hline & & $\begin{array}{l}\text { cabendo, porém, se estipulado no } \\
\text { contrato, o prévio desconto de outras } \\
\text { despesas ou encargos contratuais. }\end{array}$ & & \\
\hline 501 & $\begin{array}{l}\text { Discute-se a incidência da } \\
\text { contribuição do Plano de Seguridade } \\
\text { do Servidor Público - PSS sobre os } \\
\text { juros de mora. }\end{array}$ & $\begin{array}{l}\text { Ainda que seja possível a incidência } \\
\text { de contribuição social sobre quaisquer } \\
\text { vantagens pagas ao servidor público } \\
\text { federal }\left(\text { art. } 4^{\circ}, \S 1^{\circ} \text {, da Lei }\right. \\
10.887 / 2004) \text {, não é possível a sua } \\
\text { incidência sobre as parcelas pagas a } \\
\text { título de indenização (como é o caso } \\
\text { dos juros de mora), pois, conforme } \\
\text { expressa previsão legal (art. } 49, \text { I e } \S \\
\left.1^{\circ} \text {, da Lei } 8.112 / 90\right) \text {, não se } \\
\text { incorporam ao vencimento ou } \\
\text { provento. }\end{array}$ & REsp 1239203/PR & $12 / 12 / 2012$ \\
\hline 502 & $\begin{array}{l}\text { Definir se Gratificação Eleitoral } \\
\text { recebida pelos Escrivães e Chefes de } \\
\text { Cartório Eleitoral deve ser } \\
\text { correspondente à integralidade da } \\
\text { função comissiona exercida. }\end{array}$ & $\begin{array}{l}\text { Os servidores estaduais, que } \\
\text { exerceram as funções de Escrivão } \\
\text { Eleitoral e Chefe de Cartório das } \\
\text { zonas eleitorais do interior do } \\
\text { Estado," não têm direito de perceber" } \\
\text { a gratificação eleitoral, no período de } \\
1996 \text { a 2004, correspondente à } \\
\text { integralidade das Funções } \\
\text { Comissionadas FC-03 e FC-01, } \\
\text { respectivamente. }\end{array}$ & REsp 1258303/PB & $12 / 02 / 2014$ \\
\hline 506 & $\begin{array}{l}\text { EXECUÇÃO DE SENTENÇA. } \\
\text { ARBITRAMENTO DE } \\
\text { HONORÁRIOS SUCUMBENCIAIS } \\
\text { REFERENTES À FASE } \\
\text { EXECUTÓRIA DO JULGADO, } \\
\text { APÓS PROMOÇÃO DO ATO } \\
\text { CITATÓRIO. PRECLUSÃO. }\end{array}$ & $\begin{array}{l}\text { Hipótese de ocorrência da preclusão } \\
\text { lógica a que se refere o legislador no } \\
\text { art. } 503 \text { do CPC, segundo o qual 'A } \\
\text { parte, que aceitar expressa ou } \\
\text { tacitamente a sentença ou a decisão, } \\
\text { não poderá recorrer'. Isso porque, } \\
\text { apesar da expressa postulação de } \\
\text { arbitramento dos honorários na inicial } \\
\text { da execução de sentença, não houve } \\
\text { pronunciamento do magistrado por } \\
\text { ocasião do despacho citatório, } \\
\text { sobrevindo petição dos recorridos em } \\
\text { momento posterior à citação apenas } \\
\text { para postular a retenção do valor dos } \\
\text { honorários contratuais, sem reiteração } \\
\text { da verba de sucumbência. (...) Ainda } \\
\text { que não se trate propriamente de ação } \\
\text { autônoma, por compreensão } \\
\text { extensiva, incide o enunciado da } \\
\text { Súmula } 453 / S T J \text { quando a parte } \\
\text { exequente reitera o pedido formulado } \\
\text { na inicial da execução - a fim de } \\
\text { arbitrar os honorários advocatícios } \\
\text { sucumbenciais - após o pagamento da } \\
\text { execução e o consequente } \\
\text { arquivamento do feito. }\end{array}$ & REsp 1252412/RN & $06 / 11 / 2013$ \\
\hline 507 & $\begin{array}{l}\text { Questão referente à impossibilidade da } \\
\text { cumulação da multa aplicada em razão } \\
\text { do caráter protelatório dos embargos } \\
\text { declaratórios com a imposição da } \\
\text { indenização decorrente do } \\
\text { reconhecimento da litigância de má-fé. }\end{array}$ & $\begin{array}{l}\text { A multa prevista no artigo 538, } \\
\text { parágrafo único, do Código de } \\
\text { Processo Civil tem caráter } \\
\text { eminentemente administrativo - } \\
\text { punindo conduta que ofende a } \\
\text { dignidade do tribunal e a função } \\
\text { pública do processo -, sendo possível } \\
\text { sua cumulação com a sanção prevista } \\
\text { nos artigos } 17 \text {, VII e } 18, \S 2^{\circ} \text {, do } \\
\text { Código de Processo Civil, de natureza } \\
\text { reparatória. }\end{array}$ & REsp 1250739/PA & $04 / 12 / 2013$ \\
\hline
\end{tabular}




\begin{tabular}{|c|c|c|c|c|}
\hline 508 & $\begin{array}{l}\text { Questão referente à necessidade de } \\
\text { intimação do representante da Fazenda } \\
\text { Pública nos autos de execução fiscal, } \\
\text { inclusive no segundo grau de } \\
\text { jurisdição. }\end{array}$ & $\begin{array}{l}\text { O representante da Fazenda Pública } \\
\text { Municipal (caso dos autos), em sede } \\
\text { de execução fiscal e respectivos } \\
\text { embargos, possui a prerrogativa de ser } \\
\text { intimado pessoalmente, em virtude do } \\
\text { disposto no art. } 25 \text { da Lei } 6.830 / 80 \text {, } \\
\text { sendo que tal prerrogativa também é } \\
\text { assegurada no segundo grau de } \\
\text { jurisdição, razão pela qual não é } \\
\text { válida, nessa situação, a intimação } \\
\text { efetuada, exclusivamente, por meio da } \\
\text { imprensa oficial ou carta registrada. }\end{array}$ & REsp 1268324/PA & $17 / 10 / 2012$ \\
\hline 509 & $\begin{array}{l}\text { Discute a possibilidade de a } \\
\text { concessionária de energia elétrica } \\
\text { promover cumprimento de sentença } \\
\text { declaratória de débito nos próprios } \\
\text { autos em que julgado (in)exigível o } \\
\text { custo administrativo de } 30 \% \text { referente } \\
\text { a cálculo de recuperação de consumo. }\end{array}$ & $\begin{array}{l}\text { Com a atual redação do art. } 475-\mathrm{N} \text {, } \\
\text { inc. I, do CPC, atribuiu-se 'eficácia } \\
\text { executiva' às sentenças 'que } \\
\text { reconhecem a existência de obrigação } \\
\text { de pagar quantia'. }\end{array}$ & REsp 1261888/RS & $09 / 11 / 2011$ \\
\hline 510 & $\begin{array}{l}\text { Discute-se o pagamento pelo } \\
\text { Ministério Público de despesas } \\
\text { relativas à produção de prova em } \\
\text { demanda coletiva, na forma do art. } 18 \\
\text { da Lei n. } 7.347 / 85 \text {. }\end{array}$ & $\begin{array}{l}\text { Não é possível se exigir do Ministério } \\
\text { Público o adiantamento de honorários } \\
\text { periciais em ações civis públicas. } \\
\text { Ocorre que a referida isenção } \\
\text { conferida ao Ministério Público em } \\
\text { relação ao adiantamento dos } \\
\text { honorários periciais não pode obrigar } \\
\text { que o perito exerça seu ofício } \\
\text { gratuitamente, tampouco transferir ao } \\
\text { réu o encargo de financiar ações } \\
\text { contra ele movidas. Dessa forma, } \\
\text { considera-se aplicável, por analogia, a } \\
\text { Súmula n. } 232 \text { desta Corte Superior } \\
\text { ('A Fazenda Pública, quando parte no } \\
\text { processo, fica sujeita à exigência do } \\
\text { depósito prévio dos honorários do } \\
\text { perito'), a determinar que a Fazenda } \\
\text { Pública ao qual se acha vinculado o } \\
\text { Parquet arque com tais despesas. }\end{array}$ & REsp 1253844/SC & $13 / 03 / 2013$ \\
\hline 511 & $\begin{array}{l}\text { Discute-se a aplicação dos expurgos } \\
\text { inflacionários sobre os valores } \\
\text { recebidos a título de reserva de } \\
\text { poupança de participantes de plano } \\
\text { previdenciário que dele se desligaram } \\
\text { antes do implemento das condições } \\
\text { necessárias para fruição dos } \\
\text { benefícios. }\end{array}$ & $\begin{array}{l}\text { É devida a restituição da denominada } \\
\text { reserva de poupança a ex- } \\
\text { participantes de plano de benefícios } \\
\text { de previdência privada, devendo ser } \\
\text { corrigida monetariamente conforme } \\
\text { os índices que reflitam a real inflação } \\
\text { ocorrida no período, mesmo que o } \\
\text { estatuto da entidade preveja critério } \\
\text { de correção diverso, devendo ser } \\
\text { incluídos os expurgos inflacionários } \\
\text { (Súmula 289/STJ). }\end{array}$ & REsp 1177973/DF & $14 / 11 / 2012$ \\
\hline 512 & $\begin{array}{l}\text { Discute-se a aplicação do IPC } \\
\text { atualização das parcelas restituídas a } \\
\text { título de reserva de poupança de } \\
\text { participantes de plano previdenciário } \\
\text { que dele se desligaram antes do } \\
\text { implemento das condições necessárias } \\
\text { para fruição dos benefícios. }\end{array}$ & $\begin{array}{l}\text { A atualização monetária das } \\
\text { contribuições devolvidas pela } \\
\text { entidade de previdência privada ao } \\
\text { associado deve ser calculada pelo } \\
\text { IPC, por ser o índice que melhor } \\
\text { traduz a perda do poder aquisitivo da } \\
\text { moeda." }\end{array}$ & REsp 1177973/DF & $14 / 11 / 2012$ \\
\hline 513 & $\begin{array}{l}\text { Possibilidade de aplicação dos índices } \\
\text { de correção do FGTS sobre as parcelas } \\
\text { de contribuição restituídas aos } \\
\text { participantes desligados de plano de } \\
\text { previdência privada. }\end{array}$ & $\begin{array}{l}\text { A Súmula 252/STJ, por ser específica } \\
\text { para a correção de saldos do FGTS, } \\
\text { não tem aplicação nas demandas que } \\
\text { envolvem previdência privada. }\end{array}$ & REsp 1177973/DF & $14 / 11 / 2012$ \\
\hline
\end{tabular}




\begin{tabular}{|c|c|c|c|c|}
\hline 514 & $\begin{array}{l}\text { Discute-se a validade da quitação dos } \\
\text { expurgos inflacionários, por } \\
\text { instrumento de transação. }\end{array}$ & $\begin{array}{l}\text { A quitação relativa à restituição, por } \\
\text { instrumento de transação, somente } \\
\text { alcança as parcelas efetivamente } \\
\text { quitadas, não tendo eficácia em } \\
\text { relação às verbas por ele não } \\
\text { abrangidas. Portanto, se os expurgos } \\
\text { inflacionários não foram pagos aos } \\
\text { participantes que faziam jus à } \\
\text { devolução das parcelas da } \\
\text { contribuição, não se pode considerá- } \\
\text { los saldados por recibo de quitação } \\
\text { passado de forma geral. }\end{array}$ & REsp 1183474/DF & $14 / 11 / 2012$ \\
\hline 515 & $\begin{array}{l}\text { Estabelecer se o prazo de prescrição } \\
\text { das execuções individuais de } \\
\text { julgamento de ações coletivas seria o } \\
\text { mesmo prazo prescricional destas, ou } \\
\text { seja, de cinco anos. }\end{array}$ & $\begin{array}{l}\text { No âmbito do Direito Privado, é de } \\
\text { cinco anos o prazo prescricional para } \\
\text { ajuizamento da execução individual } \\
\text { em pedido de cumprimento de } \\
\text { sentença proferida em Ação Civil } \\
\text { Pública. }\end{array}$ & REsp 1273643/PR & $27 / 02 / 2013$ \\
\hline 516 & $\begin{array}{l}\text { Discute-se o termo inicial da } \\
\text { prescrição para pleitear indenização } \\
\text { referente a licença-prêmio não gozada. }\end{array}$ & $\begin{array}{l}\text { A contagem da prescrição quinquenal } \\
\text { relativa à conversão em pecúnia de } \\
\text { licença-prêmio não gozada e nem } \\
\text { utilizada como lapso temporal para a } \\
\text { aposentadoria, tem como termo a quo } \\
\text { a data em que ocorreu a aposentadoria } \\
\text { do servidor público. }\end{array}$ & REsp 1254456/PE & $25 / 04 / 2012$ \\
\hline 517 & $\begin{array}{l}\text { Discute-se a responsabilidade civil da } \\
\text { concessionária de transporte } \\
\text { ferroviário, por morte decorrente de } \\
\text { atropelamento por trem, diante da } \\
\text { existência ou não de culpa } \\
\text { concorrente. }\end{array}$ & $\begin{array}{l}\text { A despeito de situações fáticas } \\
\text { variadas no tocante ao } \\
\text { descumprimento do dever de } \\
\text { segurança e vigilância contínua das } \\
\text { vias férreas, a responsabilização da } \\
\text { concessionária é uma constante, } \\
\text { passível de ser elidida tão somente } \\
\text { quando cabalmente comprovada a } \\
\text { culpa exclusiva da vítima. Para os fins } \\
\text { da sistemática prevista no art. 543-C } \\
\text { do CPC, citam-se algumas situações: } \\
\text { (i) existência de cercas ao longo da } \\
\text { via, mas caracterizadas pela sua } \\
\text { vulnerabilidade, insuscetíveis de } \\
\text { impedir a abertura de passagens } \\
\text { clandestinas, ainda quando existente } \\
\text { passarela nas imediações do local do } \\
\text { sinistro; (ii) a própria inexistência de } \\
\text { cercadura ao longo de toda a ferrovia; } \\
\text { (iii) a falta de vigilância constante e } \\
\text { de manutenção da incolumidade dos } \\
\text { muros destinados à vedação do acesso } \\
\text { à linha férrea pelos pedestres; (iv) a } \\
\text { ausência parcial ou total de } \\
\text { sinalização adequada a indicar o } \\
\text { perigo representado pelo tráfego das } \\
\text { composicões. }\end{array}$ & REsp 1210064/SP & $08 / 08 / 2012$ \\
\hline
\end{tabular}


518 Discute-se a responsabilidade civil da concessionária de transporte ferroviário, por morte decorrente de atropelamento em via férrea, em virtude de alegada culpa concorrente. Discute-se o prazo prescricional da ação de cobrança relativa aos expurgos inflacionários incidente sobre saldo de poupança manejada contra a MINASCAIXA, que foi sucedida pelo Estado de Minas Gerais: se quinquenal, consoante previsão do Decreto $n^{\circ} 20.910 / 32$ que disciplina a prescrição contra a Fazenda Pública, ou se vintenária, nos termos da legislação civil.

520 Discute-se a legitimidade do adquirente de imóvel por meio de "contrato de gaveta" para demandar em juízo a revisão de cláusulas pactuadas em contrato de mútuo habitacional, firmado no âmbito do Sistema Financeiro de Habitação, se realizada a cessão sem a anuência da instituição financeira.

521 Discute-se a legitimidade do adquirente de imóvel por meio de "contrato de gaveta" para demandar em juízo a revisão de cláusulas pactuadas em contrato de mútuo habitacional, firmado no âmbito do Sistema Financeiro de Habitação, se realizada a cessão sem a anuência da instituição financeira.

522 Questão referente à legitimidade do adquirente de imóvel por meio de "contrato de gaveta" para demandar em juízo a revisão de cláusulas pactuadas em contrato de mútuo habitacional, firmado no âmbito do Sistema Financeiro de Habitação, se realizada a cessão sem a anuência da instituição financeira.
A despeito de situações fáticas variadas no tocante ao

descumprimento do dever de segurança e vigilância contínua das vias férreas, a responsabilização da concessionária é uma constante, passível de ser elidida tão somente quando cabalmente comprovada a culpa exclusiva da vítima. No caso de atropelamento de pedestre em via férrea, configura-se a concorrência de causas, impondo a redução da indenização por dano moral pela metade, quando: (i) a concessionária do transporte ferroviário descumpre o dever de cercar e fiscalizar os limites da linha férrea, mormente em locais urbanos e populosos, adotando conduta negligente no tocante às necessárias práticas de cuidado e vigilância tendentes a evitar a ocorrência de sinistros; e (ii) a vítima adota conduta imprudente, atravessando a via férrea em local inapropriado.

O prazo prescricional da ação

individual de cobrança relativa a

expurgos inflacionários incidentes sobre saldo de caderneta de poupança proposta contra o Estado de Minas Gerais, sucessor da MINAS CAIXA, é vintenário, não se aplicando à espécie o Decreto ${ }^{\circ}$ 20.910/32 que disciplina a prescrição contra a Fazenda Pública.

Tratando-se de contrato de mútuo para aquisição de imóvel garantido pelo FCVS, avençado até 25/10/96 e transferido sem a interveniência da instituição financeira, o cessionário possui legitimidade para discutir e demandar em juízo questões pertinentes às obrigações assumidas e aos direitos adquiridos.

Na hipótese de contrato originário de mútuo sem cobertura do FCVS, celebrado até 25/10/96, transferido sem a anuência do agente financiador e fora das condições estabelecidas pela Lei $\mathrm{n}^{\circ} 10.150 / 2000$, o cessionário não tem legitimidade ativa para ajuizar ação postulando a revisão do respectivo contrato.

No caso de cessão de direitos sobre imóvel financiado no âmbito do Sistema Financeiro da Habitação realizada após 25/10/1996, a anuência da instituição financeira mutuante é indispensável para que o cessionário adquira legitimidade ativa para requerer revisão das condições ajustadas, tanto para os contratos garantidos pelo FCVS como para aqueles sem a cobertura do mencionado Fundo.

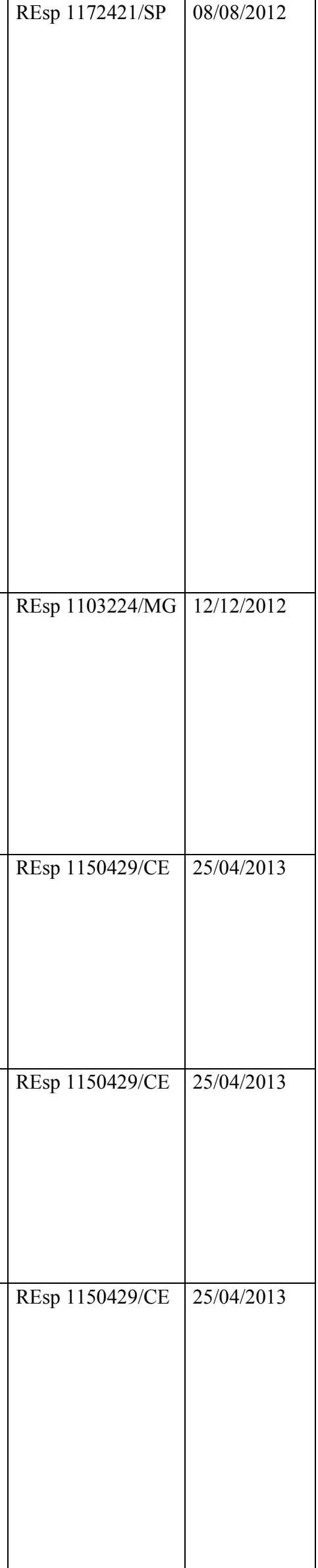


523 Questão referente à legitimidade do adquirente de imóvel por meio de "contrato de gaveta" para demandar em juízo a revisão de cláusulas pactuadas em contrato de mútuo habitacional, firmado no âmbito do Sistema Financeiro de Habitação, se realizada a cessão sem a anuência da instituição financeira.

524 Discute-se violação ao disposto no art. $3^{\circ}$ da Lei n. 9.469/97, que condiciona a concordância do pedido de desistência à renúncia do direito o qual se funda $\mathrm{a}$ ação.
526 APLICABILIDADE DO ART. 739-A, $\S 1^{\circ}$, DO CPC. ANÁLISE DO JUIZ A RESPEITO DE OCORRENNCIA DE GRAVE DANO DE DIFÍCIL OU INCERTA REPARAÇÃO PARA A CONCESSÃO DE EFEITO SUSPENSIVO AOS EMBARGOS DO DEVEDOR OPOSTOS EM EXECUÇÃO FISCAL.

527 IMPOSTO DE RENDA DA PESSOA FÍSICA. EMBARGOS À EXECUÇÃO MOVIDA CONTRA A FAZENDA PÚBLICA. VALOR PROBATÓRIO (PRESUNÇÃO DE VERACIDADE) DAS PLANILHAS PRODUZIDAS PELA SECRETARIA DA RECEITA FEDERAL E APRESENTADAS EM JUÍZO PELA PROCURADORIA-GERAL DA FAZENDA NACIONAL PARA DEMONSTRAR A AUSÊNCIA DE DEDUÇÃO DE QUANTIA RETIDA NA FONTE E JÁ RESTITUÍDA POR CONTA DE DECLARAÇÃO DE AJUSTE ANUAL.

528 Discute-se a existência de interesse de agir do consumidor para propor ação de prestação de contas, a fim de obter esclarecimentos a respeito da evolução do débito, assim também no tocante a certificação quanto à correção dos valores lançados e também apuração de eventual crédito a seu favor.

530 Discute-se a validade de notificação extrajudicial realizada por Cartório de Títulos e Documentos de Comarca diversa da do domicílio do devedor.
No caso de cessão de direitos sobre imóvel financiado no âmbito do Sistema Financeiro da Habitação realizada após 25/10/1996, a anuência da instituição financeira mutuante é indispensável para que o cessionário adquira legitimidade ativa para requerer revisão das condições ajustadas, tanto para os contratos garantidos pelo FCVS como para aqueles sem a cobertura do mencionado Fundo.

Após o oferecimento da contestação, não pode o autor desistir da ação, sem o consentimento do réu (art. 267, § $4^{\circ}$, do CPC), sendo que é legítima a oposição à desistência com fundamento no art. $3^{\circ}$ da Lei 9.469/97, razão pela qual, nesse caso, a desistência é condicionada à renúncia expressa ao direito sobre o qual se funda a ação.

A atribuição de efeitos suspensivos aos embargos do devedor" fica condicionada "ao cumprimento de três requisitos: apresentação de garantia; verificação pelo juiz da relevância da fundamentação (fumus boni juris) e perigo de dano irreparável ou de difícil reparação (periculum in mora).

\section{Em sede de embargos à execução} contra a Fazenda Pública cujo objeto é a repetição de imposto de renda, não se pode tratar como documento particular os demonstrativos de cálculo (planilhas) elaborados pela Procuradoria-Geral da Fazenda Nacional - PGFN e adotados em suas petições com base em dados obtidos junto à Secretaria da Receita Federal do Brasil - SRF (órgão público que detém todas as informações a respeito das declarações do imposto de renda dos contribuintes) por se tratarem de verdadeiros atos administrativos enunciativos que, por isso, gozam do atributo de presunção de legitimidade.

\section{Nos contratos de mútuo e} financiamento, o devedor não possui interesse de agir para a ação de prestação de contas.

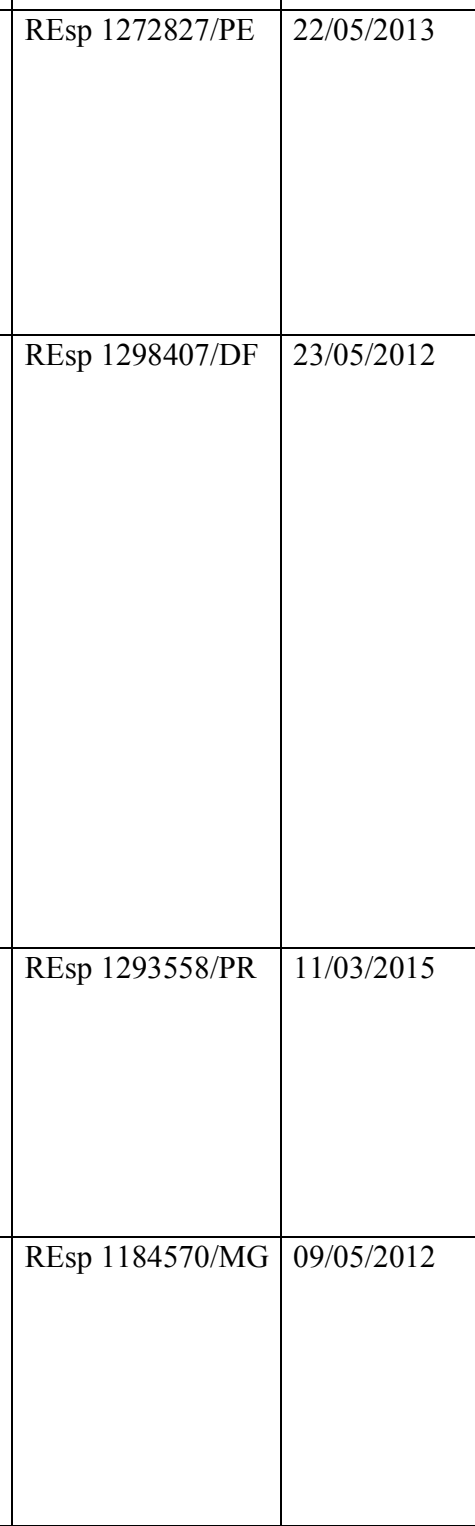

|REsp 1150429/CE |25/04/2013

REsp 1267995/PB 27/06/2012

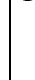


531 Discute-se a possibilidade de devolução ao Erário de valores recebidos de boa-fé pelo servidor público, quando pagos indevidamente pela Administração.

532 Discute-se a repercussão de atividade urbana do cônjuge na pretensão de configuração jurídica de trabalhador rural previsto no art. 143 da Lei $8.213 / 1991$.

33 Discute-se a repercussão de atividade urbana do cônjuge na pretensão de configuração jurídica de trabalhador rural previsto no art. 143 da Lei $8.213 / 1991$.

534 Discute-se a possibilidade de configuração do trabalho exposto ao agente perigoso eletricidade, exercido após a vigência do Decreto 2.172/1997, como atividade especial, para fins do artigo 57 da Lei $8.213 / 1991$

535 Discute-se a isenção do Imposto de Renda dos rendimentos recebidos pela parte, na condição de técnica a serviço das Nações Unidas, contratada no Brasil para atuar como consultora no âmbito doo Programa das Nações Unidas para o DesenvolvimentoPNUD.
Quando a Administração Pública interpreta erroneamente uma lei, resultando em pagamento indevido ao servidor, cria-se uma falsa expectativa de que os valores recebidos são legais e definitivos, impedindo, assim, que ocorra desconto dos mesmos, ante a boa-fé do servidor público.

O trabalho urbano de um dos membros do grupo familiar não descaracteriza, por si só, os demais integrantes como segurados especiais, devendo ser averiguada a dispensabilidade do trabalho rural para a subsistência do grupo familiar, incumbência esta das instâncias ordinárias (Súmula 7/STJ).

Em exceção à regra geral (...), a extensão de prova material em nome de um integrante do núcleo familiar a outro não é possível quando aquele passa a exercer trabalho incompatível com o labor rurícola, como o de natureza urbana.

As normas regulamentadoras que estabelecem os casos de agentes e atividades nocivos à saúde do trabalhador são exemplificativas, podendo ser tido como distinto o labor que a técnica médica e a legislação correlata considerarem como prejudiciais ao obreiro, desde que o trabalho seja permanente, não ocasional, nem intermitente, em condições especiais (art. 57, § $3^{\circ}$, da Lei 8.213/1991).

São isentos do Imposto de Renda os rendimentos do trabalho recebidos por técnicos a serviço das Nações Unidas, contratados no Brasil para atuar como consultores no âmbito do Programa das Nações Unidas para o

Desenvolvimento - PNUD. 'Peritos' a que se refere o Acordo Básico de Assistência Técnica com a Organização das Nações Unidas, suas Agências Especializadas e a Agência Internacional de Energia Atômica, promulgado pelo Decreto 59.308/66, estão ao abrigo da norma isentiva do imposto de renda. O Acordo Básico de Assistência Técnica atribuiu os benefícios fiscais decorrentes da Convenção sobre Privilégios e Imunidades das Nações Unidas, promulgada pelo Decreto $27.784 / 50$, não só aos funcionários da $\mathrm{ONU}$ em sentido estrito, mas também aos que a ela prestam serviços na condição de 'peritos de assistência técnica', no que se refere a essas atividades específicas.

\begin{tabular}{|l|l|} 
REsp 1244182/PB & $10 / 10 / 2012$ \\
\hline REsp 1304479/SP & $10 / 10 / 2012$ \\
\hline REsp 1304479/SP & $10 / 10 / 2012$ \\
\hline REsp 1306113/SC & $14 / 11 / 2012$ \\
\hline REsp 1306393/DF & $24 / 10 / 2012$ \\
& \\
& \\
& \\
& \\
& \\
& \\
& \\
& \\
& \\
& \\
& \\
\end{tabular}




\begin{tabular}{|c|c|c|c|c|}
\hline 536 & $\begin{array}{l}\text { Discute-se a necessidade de intimação } \\
\text { pessoal do devedor em cumprimento } \\
\text { de sentença, antes do que não poderá } \\
\text { incidir a multa de } 10 \% \text { sobre o valor } \\
\text { da execução. }\end{array}$ & $\begin{array}{l}\text { Na fase de cumprimento de sentença, } \\
\text { o devedor deverá ser intimado, na } \\
\text { pessoa de seu advogado, mediante } \\
\text { publicação na imprensa oficial, para } \\
\text { efetuar o pagamento no prazo de } 15 \\
\text { (quinze) dias, a partir de quando, caso } \\
\text { não o efetue, passará a incidir a multa } \\
\text { de } 10 \% \text { (dez por cento) sobre } \\
\text { montante da condenação (art. } 475-\mathrm{J} \\
\text { do CPC). }\end{array}$ & REsp 1262933/RJ & $19 / 06 / 2013$ \\
\hline 537 & $\begin{array}{l}\text { Discute-se a legitimidade do } \\
\text { consumidor para propor ação } \\
\text { declaratória cumulada com repetição } \\
\text { de indébito na qual se busca afastar, } \\
\text { no tocante ao fornecimento de energia } \\
\text { elétrica, a incidência do ICMS sobre a } \\
\text { demanda contratada e não utilizada. }\end{array}$ & $\begin{array}{l}\text { Diante do que dispõe a legislação que } \\
\text { disciplina as concessões de serviço } \\
\text { público e da peculiar relação } \\
\text { envolvendo o Estado-concedente, a } \\
\text { concessionária e o consumidor, esse } \\
\text { último tem legitimidade para propor } \\
\text { ação declaratória c/c repetição de } \\
\text { indébito na qual se busca afastar, no } \\
\text { tocante ao fornecimento de energia } \\
\text { elétrica, a incidência do ICMS sobre a } \\
\text { demanda contratada e não utilizada. }\end{array}$ & REsp 1299303/SC & $08 / 08 / 2012$ \\
\hline 538 & $\begin{array}{l}\text { Discute-se a concessão de ajuda de } \\
\text { custo a servidores públicos, prevista } \\
\text { no art. 51, I, da Lei } 8.112 / 1990 \text {, e a } \\
\text { legalidade da limitação temporal a sua } \\
\text { concessão quando fixada em norma } \\
\text { regulamentadora (art. } 7^{\circ} \text {, Resolução } \\
\text { CJF } 461 / 2005 \text {, art. } 101 \text { da Resolução } \\
\text { CJF } 4 / 2008 \text { ou norma superveniente } \\
\text { de igual conteúdo). }\end{array}$ & $\begin{array}{l}\text { A fixação de limitação temporal para } \\
\text { o recebimento da indenização prevista } \\
\text { no art. 53, I, da Lei } 8112 / 1990 \text {, por } \\
\text { meio de normas infralegais, não } \\
\text { ofende o princípio da legalidade. }\end{array}$ & REsp 1257665/CE & $08 / 10 / 2014$ \\
\hline 541 & $\begin{array}{l}\text { Discute a possibilidade de } \\
\text { creditamento do ICMS incidente sobre } \\
\text { a energia elétrica utilizada na } \\
\text { prestação de serviços de } \\
\text { telecomunicações. }\end{array}$ & $\begin{array}{l}\text { O ICMS incidente sobre a energia } \\
\text { elétrica consumida pelas empresas de } \\
\text { telefonia, que promovem processo } \\
\text { industrial por equiparação, pode ser } \\
\text { creditado para abatimento do imposto } \\
\text { devido quando da prestação de } \\
\text { serviços. }\end{array}$ & REsp 1201635/MG & $12 / 06 / 2013$ \\
\hline 542 & $\begin{array}{l}\text { Questão referente ao pagamento } \\
\text { gradativo da indenização securitária do } \\
\text { seguro DPVAT proporcionalmente ao } \\
\text { grau da lesão apurada, na hipótese de } \\
\text { invalidez parcial, no limite de R\$ } \\
\text { 13.500,00 (treze mil e quinhentos } \\
\text { reais). }\end{array}$ & $\begin{array}{l}\text { A indenização do seguro DPVAT, em } \\
\text { caso de invalidez parcial permanente } \\
\text { do beneficiário, será paga de forma } \\
\text { proporcional ao grau da invalidez. }\end{array}$ & REsp 1246432/RS & $22 / 05 / 2013$ \\
\hline 544 & $\begin{array}{l}\text { Discute a aplicação da decadência } \\
\text { prevista no art. } 103 \text { da Lei } 8.213 / 1991, \\
\text { com a redação dada pela MP } \\
1.523 / 1997, \text { sobre o direito do } \\
\text { segurado de revisar benefício } \\
\text { concedido antes da publicação deste } \\
\text { último preceito legal. }\end{array}$ & $\begin{array}{l}\text { O suporte de incidência do prazo } \\
\text { decadencial previsto no art. } 103 \text { da } \\
\text { Lei } 8.213 / 1991 \text { é o direito de revisão } \\
\text { dos benefícios, e não o direito ao } \\
\text { benefício previdenciário. Incide o } \\
\text { prazo de decadência do art. } 103 \text { da } \\
\text { Lei } 8.213 / 1991 \text {, instituído pela } \\
\text { Medida Provisória } 1.523-9 / 1997, \\
\text { convertida na Lei } 9.528 / 1997, \text { no } \\
\text { direito de revisão dos benefícios } \\
\text { concedidos ou indeferidos } \\
\text { anteriormente a esse preceito } \\
\text { normativo, com termo a quo a contar } \\
\text { da sua vigência (28.6.1997). }\end{array}$ & REsp 1309529/PR & $28 / 11 / 2012$ \\
\hline 545 & $\begin{array}{l}\text { Questiona-se a aplicação do prazo } \\
\text { prescricional previsto no art. } 1^{\circ} \text { do } \\
\text { Decreto } 20.910 / 32 \text { em demanda } \\
\text { promovida por titulares de contas } \\
\text { vinculadas ao PIS/PASEP em face da } \\
\text { União pleiteando o pagamento de } \\
\text { diferenças de correção monetária } \\
\text { expurgos inflacionários no saldo das } \\
\text { referidas contas. }\end{array}$ & $\begin{array}{l}\text { É de cinco anos o prazo prescricional } \\
\text { da ação promovida contra a União } \\
\text { Federal por titulares de contas } \\
\text { vinculadas ao PIS/PASEP visando à } \\
\text { cobrança de diferenças de correção } \\
\text { monetária incidente sobre o saldo das } \\
\text { referidas contas, nos termos do art. } 1^{\circ} \\
\text { do Decreto-Lei } 20.910 / 32 \text {. }\end{array}$ & REsp 1205277/PB & $27 / 06 / 2012$ \\
\hline
\end{tabular}


547 Discute-se o direito dos Auditores Fiscais da Receita Federal referente à impossibilidade de compensação do reajuste de $28,86 \%$ com outros títulos de natureza diversa do reajuste previsto pelas Leis 8.622 e 8.627/93, sob pena de ofensa à coisa julgada.

548 Discute-se a possibilidade de incidência do reajuste de $28,86 \%$ sobre a Retribuição de Adicional Variável - RAV, devida aos Auditores Fiscais posicionados no último padrão de vencimento quando da edição da Lei 8.627/93.

549 Discute-se o direito dos Auditores Fiscais da Receita Federal referente à fixação como limite temporal à incidência do reajuste de $28,86 \%$ a data da vigência da Medida Provisória n. $1.915 / 99$.

550 Discute-se a necessidade de homologação judicial para validar os acordos extrajudiciais celebrados para percepção das vantagens, na forma do art. $7^{\circ}$ da Medida Provisória $n$. $2.169 / 2001$.

551 Discute-se a legitimidade passiva da BRASIL TELECOM S/A para responder pelas ações não subscritas da Telecomunicações Santa CatarinaTelesc.

552 Questão referente ao prazo decadencial para a propositura da ação rescisória previsto no art. 495 do Diploma Processual deve ser prorrogado para o primeiro dia útil seguinte, quando cair em fim de semana ou feriado, nos exatos termos do art. 184, § 1. ${ }^{\circ}$, inciso I, do Código de Processo Civil.

553 Discute o prazo prescricional em ação indenizatória ajuizada contra a Fazenda Pública.

554 Discute-se a possibilidade de admitir prova exclusivamente testemunhal (art. 55, § $3^{\circ}$, da Lei 8.213/1991) para configurar tempo de serviço rural para fins previdenciários no caso do trabalhador denominado 'boia-fria'.
Havendo previsão no título executivo de exclusão de percentuais já concedidos, a mencionada imposição, em sede de embargos à execução, não importa violação da coisa julgada.

\section{O índice de $28,86 \%$ incide}

normalmente sobre a RAV.

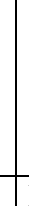

É cabível a limitação ao pagamento

do reajuste de $28,86 \%$ à data de reestruturação da carreira promovida pela Medida Provisória n. 1.915/99, a fim de que o percentual em comento seja absorvido pelos novos padrões remuneratórios estabelecidos.

\section{\begin{tabular}{l|l|l} 
É despicienda a homologação judicial & REsp 1318315/AL & 11/09/2013
\end{tabular}}

do termo de transação extrajudicial,

posto que inviável a execução de tal providência, diante da inexistência, à época da celebração do acordo, de demanda judicial entre as partes transigentes.

Legitimidade passiva da Brasil

Telecom S/A para responder pelos atos praticados pela Telesc, quanto a credores cujo título não tiver sido constituído até o ato de incorporação, independentemente de se referir a obrigações anteriores, ante a sucessão empresarial.

O termo final do prazo para o

ajuizamento da ação rescisória, embora decadencial, prorroga-se para o primeiro dia útil subsequente, se recair em dia de não funcionamento da secretaria do Juízo competente.

Aplica-se o prazo prescricional quinquenal - previsto do Decreto 20.910/32 - nas ações indenizatórias ajuizadas contra a Fazenda Pública, em detrimento do prazo trienal contido do Código Civil de 2002. Aplica-se a Súmula 149/STJ ('A prova exclusivamente testemunhal não basta à comprovação da atividade rurícola, para efeitos da obtenção de benefício previdenciário') aos trabalhadores rurais denominados 'boias-frias', sendo imprescindível a apresentação de início de prova material. Por outro lado, considerando a inerente dificuldade probatória da condição de trabalhador campesino, a apresentação de prova material somente sobre parte do lapso temporal pretendido não implica violação da Súmula 149/STJ, cuja aplicação é mitigada se a reduzida prova material
REsp 1318315/AL $11 / 09 / 2013$

REsp 1318315/AL $11 / 09 / 2013$

REsp 1318315/AL $\quad 11 / 09 / 2013$

REsp 1322624/SC $12 / 06 / 2013$

REsp 1251993/PR $\quad 12 / 12 / 2012$

REsp 1321493/PR

$10 / 10 / 2012$

\begin{tabular}{|l|l|}
\hline REsp 1112864/MG & $19 / 11 / 2014$ \\
REsp 1251993/PR & $12 / 12 / 2012$ \\
REsp 1321493/PR & $10 / 10 / 2012$ \\
& \\
& \\
&
\end{tabular}




\begin{tabular}{|c|c|c|c|c|}
\hline & & $\begin{array}{l}\text { for complementada por idônea e } \\
\text { robusta prova testemunhal. }\end{array}$ & & \\
\hline 555 & $\begin{array}{l}\text { Discute-se a possibilidade de cumular } \\
\text { auxílio-acidente com aposentadoria, } \\
\text { diante do art. } 86, \S 3^{\circ} \text {, da Lei } 8.213 / 91 \text {, } \\
\text { com a redação dada pela Medida } \\
\text { Provisória 1.596-14/97 (D.O.U. } \\
\text { 11.11.1997), posteriormente } \\
\text { convertida na Lei n. 9.528/97. }\end{array}$ & $\begin{array}{l}\text { A acumulação do auxílio-acidente } \\
\text { com proventos de aposentadoria } \\
\text { pressupõe que a eclosão da lesão } \\
\text { incapacitante, apta a gerar o direito ao } \\
\text { auxílio-acidente, e a concessão da } \\
\text { aposentadoria sejam anteriores à } \\
\text { alteração do art. } 86, \S \S 2^{\circ} \text { e } 3^{\circ} \text {, da Lei } \\
8.213 / 1991 \text {, promovida em } \\
11.11 .1997 \text { pela Medida Provisória } \\
\text { 1.596-14/1997, posteriormente } \\
\text { convertida na Lei } 9.528 / 1997 \text {. }\end{array}$ & REsp 1296673/MG & $22 / 08 / 2012$ \\
\hline 556 & $\begin{array}{l}\text { Discute-se a possibilidade de cumular } \\
\text { auxílio-acidente com aposentadoria, } \\
\text { diante do art. } 86, \S 3^{\circ} \text {, da Lei } 8.213 / 91 \text {, } \\
\text { com a redação dada pela Medida } \\
\text { Provisória 1.596-14/97 (D.O.U. } \\
\text { 11.11.1997), posteriormente } \\
\text { convertida na Lei n. 9.528/97. }\end{array}$ & $\begin{array}{l}\text { Para fins de fixação do momento em } \\
\text { que ocorre a lesão incapacitante em } \\
\text { casos de doença profissional ou do } \\
\text { trabalho, deve ser observada a } \\
\text { definição do art. } 23 \text { da Lei } \\
8.213 / 1991 \text {, segundo a qual } \\
\text { 'considera-se como dia do acidente, } \\
\text { no caso de doença profissional ou do } \\
\text { trabalho, a data do início da } \\
\text { incapacidade laborativa para o } \\
\text { exercício da atividade habitual, ou o } \\
\text { dia da segregação compulsória, ou o } \\
\text { dia em que for realizado o } \\
\text { diagnóstico, valendo para este efeito o } \\
\text { que ocorrer primeiro'. }\end{array}$ & REsp 1296673/MG & $22 / 08 / 2012$ \\
\hline 558 & $\begin{array}{l}\text { Questiona-se a faculdade ou } \\
\text { obrigatoriedade de a instituição } \\
\text { financeira promover o arrendamento } \\
\text { imobiliário especial previsto no art. } \\
38 \text {, caput e } \S 2^{\circ} \text { da Lei } \mathrm{n}^{\circ} 10.150 / 2000 \text {. }\end{array}$ & $\begin{array}{l}\text { Prescreve o art. } 38 \text { da Lei no } \\
10.150 / 2000 \text { que as instituições } \\
\text { financeiras captadoras de depósitos à } \\
\text { vista e que operem crédito imobiliário } \\
\text { estão autorizadas, e não obrigadas, a } \\
\text { promover contrato de Arrendamento } \\
\text { Imobiliário Especial com Opção de } \\
\text { Compra, dos imóveis que tenham } \\
\text { arrematado, adjudicado ou recebido } \\
\text { em dação em pagamento por força de } \\
\text { financiamentos habitacionais por elas } \\
\text { concedidos. }\end{array}$ & REsp 1161522/AL & $12 / 12 / 2012$ \\
\hline 560 & $\begin{array}{l}\text { Questão referente ao prazo de } \\
\text { prescrição da pretensão de restituição } \\
\text { de valores pagos para o custeio de } \\
\text { extensão de rede de energia elétrica. }\end{array}$ & $\begin{array}{l}\text { Em se tratando de pedido relativo a } \\
\text { valores para cujo ressarcimento não } \\
\text { havia previsão contratual (pactuação } \\
\text { prevista em instrumento, em regra, } \\
\text { nominado de 'TERMO DE } \\
\text { CONTRIBUIÇÃO'), a pretensão } \\
\text { prescreve em } 20 \text { (vinte) anos, na } \\
\text { vigência do Código Civil de } 1916 \text {, e } \\
\text { em } 3 \text { (três) anos, na vigência do } \\
\text { Código Civil de } 2002 \text {, por se tratar de } \\
\text { demanda fundada em enriquecimento } \\
\text { sem causa (art. } 206, \S 3^{\circ} \text {, inciso IV), } \\
\text { observada, igualmente, a regra de } \\
\text { transição prevista no art. } 2.028 \text { do } \\
\text { Código Civil de } 2002 .\end{array}$ & REsp 1249321/RS & $10 / 04 / 2013$ \\
\hline
\end{tabular}




\begin{tabular}{|c|c|c|c|c|}
\hline 561 & $\begin{array}{l}\text { FURTO QUALIFICADO PELO } \\
\text { CONCURSO DE AGENTES. } \\
\text { COMPATIBILIDADE COM A } \\
\text { MODALIDADE PRIVILEGIADA } \\
\text { PREVISTA NO ART. } 155, \S 2^{\circ} \text {, DO } \\
\text { CP. }\end{array}$ & $\begin{array}{l}\text { Afigura-se absolutamente 'possível o } \\
\text { reconhecimento do privilégio previsto } \\
\text { no } 2^{\circ} \text { do art. } 155 \text { do Código Penal } \\
\text { nos casos de furto qualificado (CP, } \\
\left.\text { art. } 155, \S 4^{\circ}\right)^{\prime} \text { ', máxime se presente } \\
\text { qualificadora de ordem objetiva, a } \\
\text { primariedade do réu e, também, o } \\
\text { pequeno valor da res furtiva. }\end{array}$ & REsp 1193194/MG & $22 / 08 / 2012$ \\
\hline 564 & $\begin{array}{l}\text { Discute-se a necessidade de descrição } \\
\text { da causa debendi para ajuizamento de } \\
\text { ação monitória embasada em cheque } \\
\text { prescrito. }\end{array}$ & $\begin{array}{l}\text { Em ação monitória fundada em } \\
\text { cheque prescrito, ajuizada em face do } \\
\text { emitente, é dispensável menção ao } \\
\text { negócio jurídico subjacente à emissão } \\
\text { da cártula. }\end{array}$ & REsp 1094571/SP & $04 / 02 / 2013$ \\
\hline 572 & $\begin{array}{l}\text { Questiona se a existência/inexistência } \\
\text { de juros capitalizados em contratos } \\
\text { que utilizam a Tabela Price é matéria } \\
\text { de fato - e por isso demandaria a } \\
\text { realização de provas - ou } \\
\text { exclusivamente jurídica, dispensada a } \\
\text { dilação probatória. }\end{array}$ & $\begin{array}{l}\text { A análise acerca da legalidade da } \\
\text { utilização da Tabela Price - mesmo } \\
\text { que em abstrato - passa, } \\
\text { necessariamente, pela constatação da } \\
\text { eventual capitalização de juros (ou } \\
\text { incidência de juros compostos, juros } \\
\text { sobre juros ou anatocismo), que é } \\
\text { questão de fato e não de direito, } \\
\text { motivo pelo qual não cabe ao } \\
\text { Superior Tribunal de Justiça tal } \\
\text { apreciação, em razão dos óbices } \\
\text { contidos nas Súmulas } 5 \text { e } 7 \text { do STJ.É } \\
\text { exatamente por isso que, em contratos } \\
\text { cuja capitalização de juros seja } \\
\text { vedada, é necessária a interpretação } \\
\text { de cláusulas contratuais e a produção } \\
\text { de prova técnica para aferir a } \\
\text { existência da cobrança de juros não } \\
\text { lineares, incompatíveis, portanto, com } \\
\text { financiamentos celebrados no âmbito } \\
\text { do Sistema Financeiro da Habitação } \\
\text { antes da vigência da Lei n. } \\
\text { 11.977/2009, que acrescentou o art. } \\
15-A \text { à Lei n. 4.380/1964. Em se } \\
\text { verificando que matérias de fato ou } \\
\text { eminentemente técnicas foram } \\
\text { tratadas como exclusivamente de } \\
\text { direito, reconhece-se o cerceamento, } \\
\text { para que seja realizada a prova } \\
\text { pericial. }\end{array}$ & REsp 1124552/RS & $03 / 12 / 2014$ \\
\hline 574 & $\begin{array}{l}\text { Estabelecer o prazo prescricional para } \\
\text { a pretensão de cobrança dos valores } \\
\text { pagos pelo consumidor a título de } \\
\text { contribuição para a construção das } \\
\text { chamadas Plantas Comunitárias de } \\
\text { Telefonia. }\end{array}$ & $\begin{array}{l}\text { A pretensão de ressarcimento do valor } \\
\text { pago pelo custeio de Plantas } \\
\text { Comunitárias de Telefonia (PCTs), } \\
\text { não existindo previsão contratual de } \\
\text { reembolso pecuniário ou por ações da } \\
\text { companhia, submete-se ao prazo de } \\
\text { prescrição de } 20 \text { (vinte) anos, na } \\
\text { vigência do Código Civil de } 1916 \text { (art. } \\
\text { 177), e de } 3 \text { (três) anos, na vigência } \\
\text { do Código Civil de } 2002 \text {, por se tratar } \\
\text { de demanda fundada em } \\
\text { enriquecimento sem causa (art. } 206, \S \\
3^{\circ} \text {, inc. IV), observada a fórmula de } \\
\text { transição prevista no art. } 2.028 \text { do } \\
\text { mesmo diploma legal. }\end{array}$ & REsp 1220934/RS & $24 / 04 / 2013$ \\
\hline
\end{tabular}


575 Questão referente à pretensão de restituição dos valores pagos para o custeio de extensão de rede de energia elétrica.
1. A participação financeira do consumidor no custeio de construção de rede elétrica não é, por si só, ilegal, uma vez que, na vigência do Decreto n. 41.019/57, havia previsão normativa de obras que deviam ser custeadas pela concessionária (art. 141), pelo consumidor (art. 142), ou por ambos (art.138 e art. 140).2. Em contratos regidos pelo Decreto $\mathrm{n}$. $41.019 / 57$, o consumidor que solicitara a extensão da rede de eletrificação rural não tem direito à restituição dos valores aportados, salvo na hipótese de (i) ter adiantado parcela que cabia à concessionária em caso de responsabilidade conjunta (arts. 138 e 140) - ou (ii) ter custeado obra cuja responsabilidade era exclusiva da concessionária (art. 141). Leva-se em consideração, em ambos os casos, a normatização editada pelo Departamento Nacional de Águas e Energia Elétrica - DNAEE, que definia os encargos de responsabilidade da concessionária e do consumidor, relativos a pedidos de extensão de redes de eletrificação, com base na natureza de cada obra.3. À míngua de comprovação de que os valores cuja restituição se pleiteia eram de responsabilidade da concessionária, não sendo o caso de inversão do ônus da prova e não existindo previsão contratual para o reembolso, o pedido de devolução deve ser julgado improcedente.

576 Discute-se a força executiva da Cédula de Crédito Bancário, título de crédito disciplinado pela Lei n. 10.931/2004.

577 Discussão referente à forma de devolução dos valores devidos ao promitente comprador (se imediatamente ou somente ao término da obra) em razão da rescisão do contrato de promessa de compra e venda de imóvel.

578 Discute se a parte executada, ainda que não apresente elementos concretos que justifiquem a incidência do princípio da menor onerosidade (art. 620 do CPC), possui direito subjetivo à aceitação do bem por ela nomeado à penhora em Execução Fiscal, em desacordo com a ordem prevista nos arts. 11 da lei $6.830 / 1980$ e 655 do CPC.

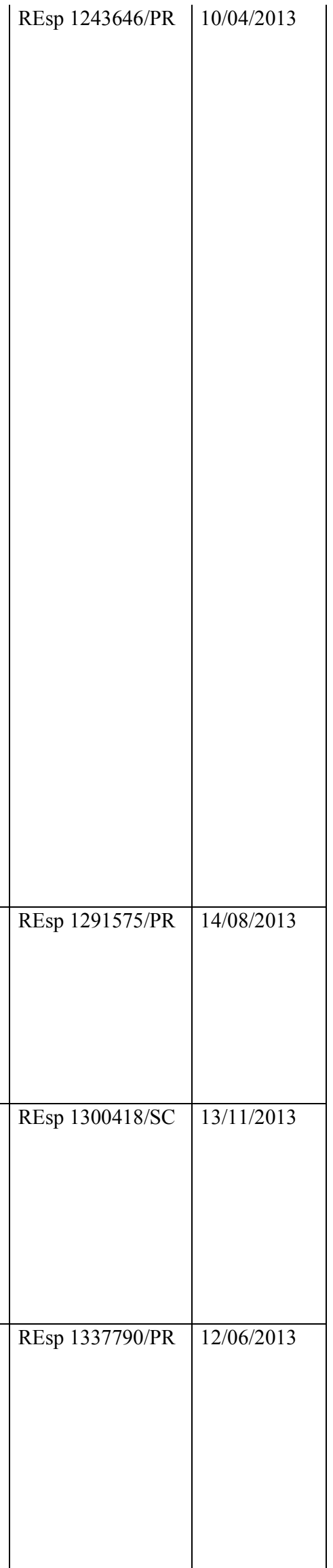


580 Discute-se a prerrogativa de o procurador de Conselho de Fiscalização ser intimado pessoalmente nos autos de execução fiscal, nos termos do art. 25 da Lei 6.830/80.

581 Questão relativa à natureza hedionda dos crimes de estupro e atentado violento ao pudor quando praticados na forma simples.

582 SERVIDOR PÚBLICO FEDERAL. LEI 11.907/09. PLANO ESPECIAL DE CARGOS E SALÁRIOS DO MINISTÉRIO DA FAZENDA. GRATIFICAÇÃO DE ATIVIDADE EXECUTIVA. GAE. INCORPORAÇÃO AO VENCIMENTO BÁSICO.
584 Discute-se, com base na Lei de Diretrizes e Bases da Educação, a competência para o julgamento de demandas referentes à existência de obstáculo à obtenção do diploma após a conclusão de curso de ensino a distância, por causa da ausência/obstáculo de credenciamento da instituição de ensino superior pelo Ministério da Educação.
Em execução fiscal ajuizada por Conselho de Fiscalização

Profissional, seu representante judicial possui a prerrogativa de ser pessoalmente intimado.

Os crimes de estupro e atentado

violento ao pudor praticados antes da edição da Lei n ${ }^{\circ} 12.015 / 2009$, ainda que em sua forma simples, configuram modalidades de crime hediondo.

A Lei n. 11.907/2009, que (...)

produziu efeitos financeiros

retroativos a 1/7/2008, determinou a incorporação da GAE ao vencimento básico dos servidores a partir de $1 / 7 / 2008$ e estabeleceu que, para evitar pagamento em duplicidade dos valores da GAE, a nova remuneração (que já continha os valores da GAE incorporados) não poderia ser cumulada com os valores já percebidos anteriormente pelos servidores a título de GAE.

Em se tratando de demanda em que se discute a ausência/obstáculo de credenciamento da instituição de ensino superior pelo Ministério da Educação como condição de expedição de diploma aos estudantes, é inegável a presença de interesse jurídico da União, razão pela qual deve a competência ser atribuída à Justiça Federal, nos termos do art. 109, I, da Constituição Federal de 1988.

585 Discute-se a possibilidade de compensação da atenuante da confissão espontânea com a agravante da reincidência.

589 Discute-se a possibilidade de suspensão, nos termos da legislação vigente, do andamento de inúmeros processos até o julgamento em ação coletiva da tese jurídica de fundo neles indicada.

590 EXECUÇÃO FISCAL. RESPOSTA DAS INSTITUIÇÕES

FINANCEIRAS AO OFÍCIO DE REQUISIÇÃO DE INFORMAÇÃO DE ATIVOS FINANCEIROS VIA BACEN-JUD. DOCUMENTOS SIGILOSOS. DISCUSSÃO A RESPEITO DA NECESSIDADE DE ARQUIVAMENTO EM "PASTA PRÓPRIA" FORA DOS AUTOS OU DECRETAÇÃO DE SEGREDO DE JUSTIÇA. ART. 155, I, DO CPC.

591 GRATIFICAÇÃO DE ATIVIDADE EXECUTIVA - GAE. PERCEPÇÃO PELOS ADVOGADOS DA UNIÃO. MP N. 2.048-26/2000.

É possível, na segunda fase da

dosimetria da pena, a compensação da atenuante da confissão espontânea com a agravante da reincidência.

Ajuizada ação coletiva atinente a macro-lide geradora de processos multitudinários, suspendem-se as ações individuais, no aguardo do julgamento da ação coletiva.

As informações sigilosas das partes devem ser juntadas aos autos do processo que correrá em segredo de justiça, não sendo admitido o arquivamento em apartado.

Não prospera a tese dos autores de que a supressão da GAE pelo art. 59 da MP 2.048-26/0000 diz respeito apenas aos cargos referidos no art. $1^{\circ}$ desta medida provisória (artigo este que não cita o cargo de Advogado da União). Isso porque o art. 41 da MP 2.048-26/0000, que menciona o cargo

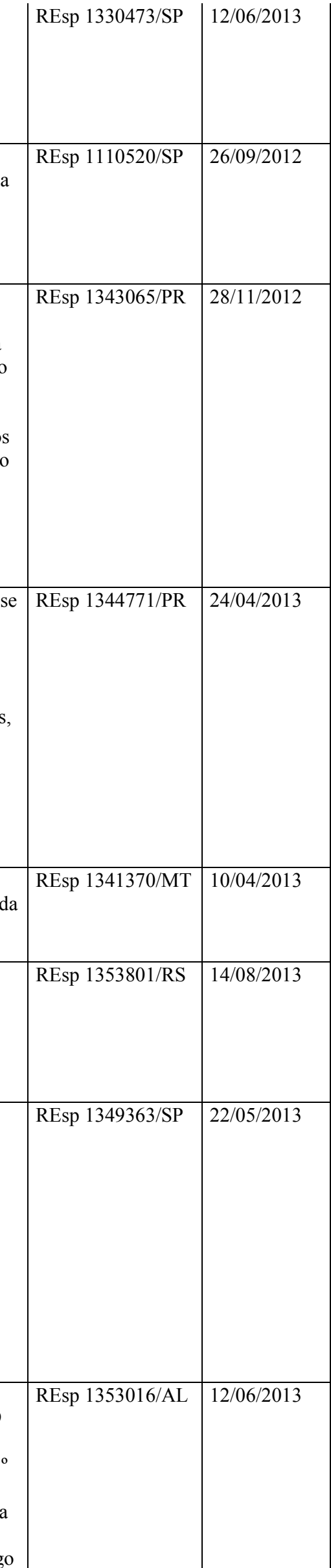




\begin{tabular}{|c|c|c|c|c|}
\hline & & $\begin{array}{l}\text { de Advogado da União, deve ser } \\
\text { interpretado sistemática e } \\
\text { teleologicamente com o art. } 59 \text { do } \\
\text { mesmo diploma legal. }\end{array}$ & & \\
\hline 593 & $\begin{array}{l}\text { PENAL E PROCESSO PENAL. } \\
\text { RECURSO ESPECIAL. OFENSA AO } \\
\text { ART. 184, § 2, DO CP. } \\
\text { MERCANCIA DE CD'S E DVD'S } \\
\text { "PIRATAS". ATIPICIDADE DA } \\
\text { CONDUTA EM FACE DO } \\
\text { PRINCÍPIO DA ADEQUAÇÃO } \\
\text { SOCIAL. }\end{array}$ & $\begin{array}{l}\text { Considera-se "típica, formal e } \\
\text { materialmente, a conduta prevista no } \\
\text { artigo } 184, \S 2^{\circ} \text {, do Código Penal, } \\
\text { afastando, assim, a aplicação do } \\
\text { princípio da adequação social, de } \\
\text { quem expõe à venda CD's E DVD's } \\
\text { 'piratas'." }\end{array}$ & REsp 1193196/MG & $26 / 09 / 2012$ \\
\hline 594 & $\begin{array}{l}\text { Discute-se a possibilidade de } \\
\text { recolhimento do PIS e da COFINS, } \\
\text { utilizando como base de cálculo } \\
\text { somente a diferença entre o valor de } \\
\text { alienação dos veículos novos que } \\
\text { transaciona e o respectivo custo } \\
\text { repassado para a montadora que os } \\
\text { fornece ("margem de lucro"), e não } \\
\text { sobre o preço de venda fixado pela } \\
\text { pessoa jurídica fabricante (montadora). }\end{array}$ & $\begin{array}{l}\text { As empresas concessionárias de } \\
\text { veículos, em relação aos veículos } \\
\text { novos, devem recolher PIS e COFINS } \\
\text { na forma dos arts.. } 2^{\circ} \text { e } 3^{\circ} \text {, da Lei n. } \\
9.718 / 98 \text {, ou seja, sobre a receita } \\
\text { bruta/faturamento (compreendendo o } \\
\text { valor da venda do veículo ao } \\
\text { consumidor) e não sobre a diferença } \\
\text { entre o valor de aquisição do veículo } \\
\text { junto à fabricante concedente e o } \\
\text { valor da venda ao consumidor } \\
\text { (margem de lucro). }\end{array}$ & REsp 1339767/SP & $26 / 06 / 2013$ \\
\hline 595 & $\begin{array}{l}\text { PIS/PASEP E COFINS. ART. } 3^{\circ}, \S^{\circ}{ }^{\circ}, \\
\text { DA LEI N. 9.718/98. DISCUSSÃO A } \\
\text { RESPEITO DO CONCEITO DE } \\
\text { FATURAMENTO/RECEITA } \\
\text { BRUTA PARA AS PESSOAS } \\
\text { JURÍDICAS TRIBUTADAS PELO } \\
\text { IMPOSTO DE RENDA COM BASE } \\
\text { NO LUCRO PRESUMIDO OU } \\
\text { ARBITRADO. ART. } 8^{\circ}, \text { II, DA LEI } \\
\text { N. 10.637/2002 (PIS) E ART. 10, II, } \\
\text { DA LEI N. } 10.833 / 2003 \text { (COFINS). }\end{array}$ & $\begin{array}{l}\text { Reconhecido o direito à repetição de } \\
\text { indébito com base na } \\
\text { inconstitucionalidade do art. } 3^{\circ}, \S 1^{\circ} \text {, } \\
\text { da Lei n. } 9.718 / 98 \text {, deve ser } \\
\text { reconhecido o mesmo direito após a } \\
\text { vigência das Leis n. } 10.637 / 2002 \text { e } \\
10.833 / 2003 \text { para as pessoas jurídicas } \\
\text { tributadas pelo imposto de renda com } \\
\text { base no lucro presumido ou arbitrado, } \\
\text { diante da aplicação do art. } 8^{\circ}, \text { II, da } \\
\text { Lei n. } 10.637 / 2002 \text { e do art. } 10, \mathrm{II}, \text { da } \\
\text { Lei n. } 10.833 / 2003 \text {, que excluem tais } \\
\text { pessoas jurídicas da cobrança não- } \\
\text { cumulativa do PIS e da COFINS. }\end{array}$ & REsp 1354506/SP & $14 / 08 / 2013$ \\
\hline 596 & $\begin{array}{l}\text { Posse ilegal de arma de fogo de uso } \\
\text { permitido com numeração raspada, } \\
\text { suprimida ou adulterada (art. 16, } \\
\text { parágrafo único, IV, da Lei n. } \\
10.826 / 2003 \text { ). Abolitio criminis } \\
\text { temporária. Prorrogações. Termo final. }\end{array}$ & $\begin{array}{l}\text { É típica a conduta de possuir arma de } \\
\text { fogo de uso permitido com } \\
\text { numeração, marca ou qualquer outro } \\
\text { sinal de identificação raspado, } \\
\text { suprimido ou adulterado, praticada } \\
\text { após } 23 / 10 / 2005 \text {, pois, em relação a } \\
\text { esse delito, a abolitio criminis } \\
\text { temporária cessou nessa data, termo } \\
\text { final da prorrogação dos prazos } \\
\text { previstos na redação original dos arts.. } \\
30 \text { e } 32 \text { da Lei n. } 10.826 / 2003 \text {. } \\
\end{array}$ & REsp 1311408/RN & $13 / 03 / 2013$ \\
\hline 598 & $\begin{array}{l}\text { Questão referente à possibilidade de } \\
\text { inscrição em dívida ativa de benefício } \\
\text { previdenciário indevidamente } \\
\text { recebido, qualificado como } \\
\text { enriquecimento ilícito. }\end{array}$ & $\begin{array}{l}\text { À mingua de lei expressa, a inscrição } \\
\text { em dívida ativa não é a forma de } \\
\text { cobrança adequada para os valores } \\
\text { indevidamente recebidos a título de } \\
\text { benefício previdenciário previstos no } \\
\text { art. } 115, \text { II, da Lei n. } 8.213 / 91 \text { que } \\
\text { devem submeter-se a ação de } \\
\text { cobrança por enriquecimento ilícito } \\
\text { para apuração da responsabilidade } \\
\text { civil. }\end{array}$ & REsp 1350804/PR & $12 / 06 / 2013$ \\
\hline
\end{tabular}


599 Discute-se a possibilidade das Universidades fixarem regras específicas para o recebimento e processamento dos pedidos de revalidação de Diploma obtido em Universidade estrangeira.
601 Questão referente à validade da intimação da Fazenda Nacional, feita por meio de carta, em razão de sua sede possuir localização em cidade distinta da Comarca em que tramita a Execução Fiscal (inteligência do art. 25 da Lei 6.830/1980, do art. 38 da LC $73 / 1993$ e do art. 20 da Lei 11.033/2004).

602 Discute-se a constatação de interesse processual e da ocorrência da prescrição do fundo de direito da pretensão de incidência dos reajustes da Lei Estadual 10.395/1995 sobre o percentual de $20 \%$ da Parcela Autônoma do Magistério (PAM) do Rio Grande do Sul.

603 Discute-se a possibilidade de promoção de anistiado político (art. $6^{\circ}$ da Lei 10.559/2002) para carreira militar diversa da que ele integra.
O art. 53, inciso V, da Lei 9394/96 permite à universidade fixar normas específicas a fim de disciplinar o referido processo de revalidação de diplomas de graduação expedidos por estabelecimentos estrangeiros de ensino superior, não havendo qualquer ilegalidade na determinação do processo seletivo para a revalidação do diploma, porquanto decorre da necessidade de adequação dos procedimentos da instituição de ensino para o cumprimento da norma, uma vez que de outro modo não teria a universidade condições para verificar a capacidade técnica do profissional e sua formação, sem prejuízo da responsabilidade social que envolve o ato.

É válida a intimação do representante da Fazenda Nacional por carta com aviso de recebimento (art. 237, II, do CPC) quando o respectivo órgão não possui sede na Comarca de tramitação do feito.

A incorporação da PAM aos vencimentos dos servidores continua a gerar efeitos financeiros de trato sucessivo, de forma que a revisão daquela parcela repercute continuamente na esfera jurídicopatrimonial do servidor. Incide no caso a regra geral da Súmula $85 / \mathrm{STJ}$, segundo a qual 'nas relações jurídicas de trato sucessivo em que a Fazenda Pública figure como devedora, quando não tiver sido negado $o$ próprio direito reclamado, a prescrição atinge apenas as prestações vencidas antes do quinquênio anterior à propositura da ação.'

O militar anistiado tem direito a todas as promoções a que faria jus se na ativa estivesse, considerando-se a situação dos paradigmas $\left(\S 4^{\circ}\right.$ do art. $6^{\circ}$ da Lei 10.529/2002). A

possibilidade de promoção, contudo, é restrita ao quadro de carreira a que $o$ militar pertencia à época da concessão da anistia política.

604 Discussão a respeito da possibilidade de documento de confissão de dívida tributária poder constituir o crédito tributário mesmo após o prazo decadencial previsto no art. 173 , I, do CTN.
A decadência, consoante a letra do art. 156, V, do CTN, é forma de extinção do crédito tributário. Sendo assim, uma vez extinto o direito, não pode ser reavivado por qualquer sistemática de lançamento ou autolançamento, seja ela via documento de confissão de dívida, declaração de débitos, parcelamento ou de outra espécie qualquer (DCTF, GIA, DCOMP, GFIP, etc.).

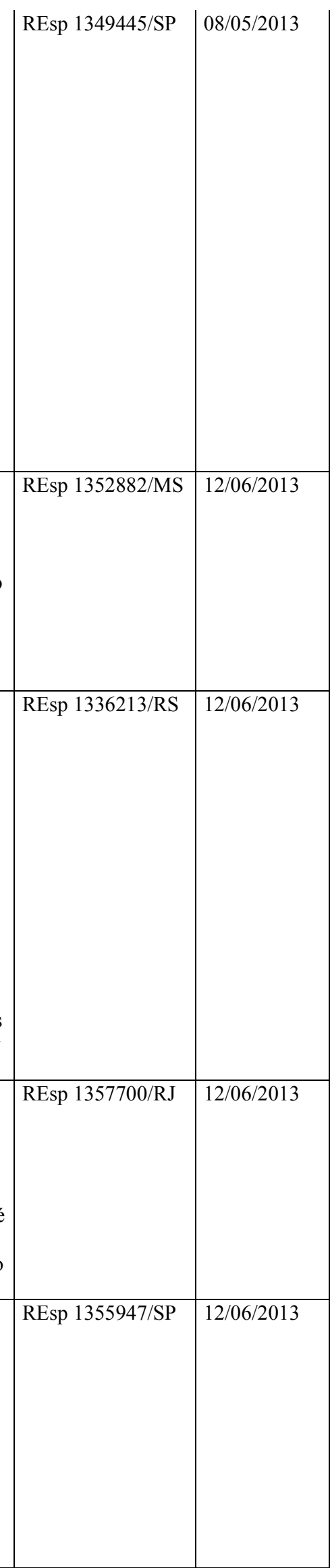




\begin{tabular}{|c|c|c|c|c|}
\hline 606 & $\begin{array}{l}\text { Questão referente à possibilidade do o } \\
\text { ajuizamento de ação de cobrança } \\
\text { referente ao seguro obrigatório } \\
\text { DPVAT no foro de domicílio da ré, } \\
\text { não podendo o Juízo declinar de ofício } \\
\text { da competência para o julgamento da } \\
\text { ação. }\end{array}$ & $\begin{array}{l}\text { Em ação de cobrança objetivando } \\
\text { indenização decorrente de Seguro } \\
\text { Obrigatório de Danos Pessoais } \\
\text { Causados por Veículos Automotores } \\
\text { de Vias Terrestres - DPVAT, constitui } \\
\text { faculdade do autor escolher entre os } \\
\text { seguintes foros para ajuizamento da } \\
\text { ação: o do local do acidente ou o do } \\
\text { seu domicílio (parágrafo único do art. } \\
100 \text { do Código de Processo Civil); } \\
\text { bem como, ainda, o do domicílio do } \\
\text { réu (art. } 94 \text { do mesmo Diploma). }\end{array}$ & REsp 1357813/RJ & $11 / 09 / 2013$ \\
\hline 608 & $\begin{array}{l}\text { Cinge-se a discussão em definir se o } \\
\text { valor da execução pode ser fracionado, } \\
\text { a ponto de permitir o pagamento dos } \\
\text { honorários advocatícios por meio de } \\
\text { RPV e o crédito principal por meio de } \\
\text { precatórios judicial. }\end{array}$ & $\begin{array}{l}\text { Não há impedimento constitucional, } \\
\text { ou mesmo legal, para que os } \\
\text { honorários advocatícios, quando não } \\
\text { excederem ao valor limite, possam ser } \\
\text { executados mediante RPV, ainda que } \\
\text { o crédito dito 'principal' observe o } \\
\text { regime dos precatórios. }\end{array}$ & REsp 1347736/RS & $09 / 10 / 2013$ \\
\hline 610 & $\begin{array}{l}\text { Discussão sobre o prazo prescricional } \\
\text { para exercício da pretensão de revisão } \\
\text { de cláusula contratual que prevê } \\
\text { reajuste de plano de saúde e respectiva } \\
\text { repetição dos valores supostamente } \\
\text { pagos a maior. }\end{array}$ & $\begin{array}{l}\text { Na vigência dos contratos de plano ou } \\
\text { de seguro de assistência à saúde, a } \\
\text { pretensão condenatória decorrente da } \\
\text { declaração de nulidade de cláusula de } \\
\text { reajuste nele prevista prescreve em } 20 \\
\text { anos (art. } 177 \text { do CC/1916) ou em } 3 \\
\text { anos (art. } 206, \S 3^{\circ}, \mathrm{IV} \text {, do CC } / 2002 \text { ), } \\
\text { observada a regra de transição do art. } \\
2.028 \text { do CC } / 2002 \text {. } \\
\end{array}$ & REsp 1360969/RS & $10 / 08 / 2016$ \\
\hline 611 & $\begin{array}{l}\text { Cinge-se a discussão em fixar o termo } \\
\text { inicial dos juros moratórios incidentes } \\
\text { sobre diferenças remuneratórias } \\
\text { cobradas em juízo por servidor } \\
\text { público. Para o acórdão recorrido, com } \\
\text { o advento do art. } 1^{\circ} \text {-F da Lei } 9.494 / 97, \\
\text { redação da Lei } 11.960 / 09 \text {, os juros } \\
\text { incidem a partir da data em que } \\
\text { deveria ter sido adimplida cada } \\
\text { parcela, enquanto o recorrente defende } \\
\text { que o termo inicial é a data da citação, } \\
\text { nos termos dos arts. } 219 \text { do CPC, e } \\
405 \text { do CC, disciplina que não sofreu } \\
\text { qualquer alteração com o art. } 1^{\circ}-F \text {, que } \\
\text { nada dispõe sobre o termo inicial dos } \\
\text { juros. }\end{array}$ & $\begin{array}{l}\text { O art. } 1^{\circ} \text {-F da Lei 9.494/97, com a } \\
\text { redação da Lei 11.960/09, não } \\
\text { modificou o termo a quo de } \\
\text { incidência dos juros moratórios sobre } \\
\text { as obrigações ilíquidas devidas pela } \\
\text { Administração ao servidor público, } \\
\text { aplicando-se, consequentemente, as } \\
\text { regras constantes dos arts. } 219 \text { do } \\
\text { CPC e } 405 \text { do Código Civil, os quais } \\
\text { estabelecem a citação como marco } \\
\text { inicial da referida verba. }\end{array}$ & REsp 1356120/RS & $14 / 08 / 2013$ \\
\hline 612 & $\begin{array}{l}\text { Questão referente à possibilidade de } \\
\text { aplicação do artigo } 20 \text { da Lei } \\
10.522 / 2002 \text {, que determina o } \\
\text { arquivamento provisório das } \\
\text { execuções de pequeno valor, às } \\
\text { execuções fiscais propostas pelos } \\
\text { Conselhos Regionais de Fiscalização } \\
\text { Profissional. }\end{array}$ & $\begin{array}{l}\text { Da simples leitura do artigo em } \\
\text { comento, verifica-se que a } \\
\text { determinação nele contida, de } \\
\text { arquivamento, sem baixa, das } \\
\text { execuções fiscais referentes aos } \\
\text { débitos com valores inferiores a R\$ } \\
10.000,00 \text { (dez mil reais) destina-se } \\
\text { exclusivamente aos débitos inscritos } \\
\text { como dívida ativa da União, pela } \\
\text { Procuradoria da Fazenda Nacional ou } \\
\text { por ela cobrados. }\end{array}$ & REsp 1363163/SP & $11 / 09 / 2013$ \\
\hline 614 & $\begin{array}{l}\text { DÉBITOS TRIBUTÁRIOS DA } \\
\text { MATRIZ. DISCUSSÃO A } \\
\text { RESPEITO DA POSSIBILIDADE DE } \\
\text { BLOQUEIO DE DEPÓSITOS DE } \\
\text { TITULARIDADE DAS FILIAIS. }\end{array}$ & $\begin{array}{l}\text { Inexiste óbices à penhora, em face de } \\
\text { dívidas tributárias da matriz, de } \\
\text { valores depositados em nome das } \\
\text { filiais. }\end{array}$ & REsp 1355812/RS & $22 / 05 / 2013$ \\
\hline
\end{tabular}


615 Cinge-se a discussão em definir se diploma estrangeiro, expedido em um dos países signatários da Convenção Regional sobre o Reconhecimento de Diploma de Ensino Superior na América Latina e no Caribe, aprovada pelo Decreto Legislativo n. ${ }^{\circ}$ 66/77 e promulgada pelo Decreto Presidencial n. ${ }^{\circ} 80.419 / 77$, deve ser registrado automaticamente no país, independentemente de processo de revalidação.
618 Questão referente à possibilidade de cobranças das taxas/tarifas administrativas para abertura de crédito e de emissão de carnê e de pagamento parcelado do Imposto sobre Operações Financeiras (IOF), dentre outros encargos.

619 Questão referente à possibilidade de cobranças das taxas/tarifas administrativas para abertura de crédito e de emissão de carnê e de pagamento parcelado do Imposto sobre Operações Financeiras (IOF), dentre outros encargos.
620 Questão referente à possibilidade de cobranças das taxas/tarifas administrativas para abertura de crédito e de emissão de carnê e de pagamento parcelado do Imposto sobre Operações Financeiras (IOF), dentre outros encargos.

621 Questão referente à possibilidade de cobranças das taxas/tarifas administrativas para abertura de crédito e de emissão de carnê e de pagamento parcelado do Imposto sobre Operações Financeiras (IOF), dentre outros encargos.

622 Discute-se a necessidade ou não de ajuizamento de ação autônoma ou de oferecimento de reconvenção para que o réu faça jus à devolução em dobro por cobrança de dívida paga (artigo 1.531 do Código Civil de 1916, atual artigo 940 do Código Civil de 2002).
A Convenção Regional sobre o Reconhecimento de Diploma de Ensino Superior na América Latina e no Caribe, aprovada pelo Decreto Legislativo n. ${ }^{\circ} 66 / 77$ e promulgada pelo Decreto Presidencial n. ${ }^{\circ}$ $80.419 / 77$, possui nítido caráter programático ao determinar que os países signatários criem mecanismos para torná-la efetiva, inexistindo, portanto, determinação específica de reconhecimento automático dos diplomas. Concluiu-se, no presente julgado, que o Decreto $\mathrm{n}^{\circ}$ $80.419 / 77: 1)$ não foi revogado pelo Decreto n. 3.007/99;2) não traz norma específica que vede o procedimento de revalidação dos diplomas que têm respaldo nos artigos 48 e 53, V, da Lei de Diretrizes e Bases da Educação Brasileira.

Nos contratos bancários celebrados até 30/04/2008 (fim da vigência da Resolução CMN 2.303/96) era válida a pactuação das Tarifas de Abertura de Crédito (TAC) e de Emissão de Carnê (TEC), ou outra denominação para o mesmo fato gerador, ressalvado o exame de abusividade em cada caso concreto.

Com a vigência da Resolução CMN 3.518/2007, em 30/04/2008, a cobrança por serviços bancários prioritários para pessoas físicas ficou limitada às hipóteses taxativamente previstas em norma padronizadora expedida pela autoridade monetária. Desde então, não tem respaldo legal a contratação da Tarifa de Emissão de Carnê (TEC) e da Tarifa de Abertura de Crédito (TAC), ou outra denominação para o mesmo fato gerador.

Permanece válida a tarifa de cadastro expressamente tipificada em ato normativo padronizador da autoridade monetária, a qual somente pode ser cobranda do início do relacionamento entre o consumidor e a instituição financeira.

Podem as partes convencionar o pagamento do Imposto sobre Operações Financeiras e de Crédito (IOF) por meio de financiamento acessório ao mútuo principal, sujeitando-o aos mesmos encargos contratuais.

A aplicação da sanção civil do pagamento em dobro por cobrança judicial de dívida já adimplida (cominação encartada no artigo 1.531 do Código Civil de 1916, reproduzida no artigo 940 do Código Civil de 2002) pode ser postulada pelo réu na própria defesa, independendo da propositura de ação autônoma ou do manejo de reconvenção, sendo

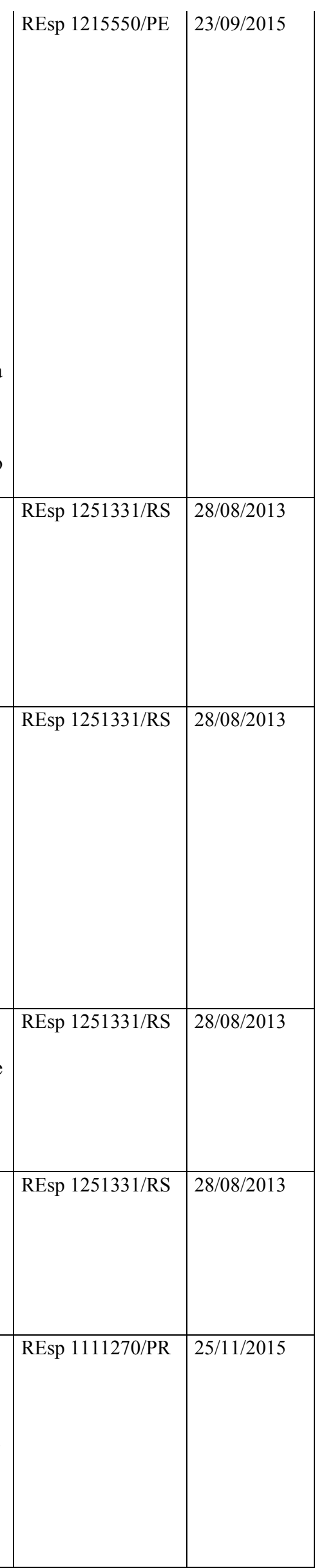




\begin{tabular}{|c|c|c|c|c|}
\hline & & $\begin{array}{l}\text { imprescindível a demonstração de } \\
\text { má-fé do credor. }\end{array}$ & & \\
\hline 624 & $\begin{array}{l}\text { Discute-se a isenção da Cofins às } \\
\text { atividades próprias das entidades sem } \\
\text { fins lucrativos para fins de gozo da } \\
\text { isenção prevista no art. } 14, X \text {, da MP } \\
\text { n. } 2.158-35 / 2001 \text {. Verificação da } \\
\text { legalidade do art. } 47 \text {, II e } \S 2^{\circ} \text {, da } \\
\text { Instrução Normativa SRF n. } 247 / 2002 \text {. } \\
\text { Sociedade civil educacional ou de } \\
\text { caráter cultural e científico. }\end{array}$ & $\begin{array}{l}\text { As receitas auferidas a título de } \\
\text { mensalidades dos alunos de } \\
\text { instituições de ensino sem fins } \\
\text { lucrativos são decorrentes de } \\
\text { "atividades próprias da entidade", } \\
\text { conforme o exige a isenção } \\
\text { estabelecida no art. } 14 \text {, X, da Medida } \\
\text { Provisória n. } 1.858 / 99 \text { (atual MP n. } \\
2.158-35 / 2001 \text { ), sendo flagrante a } \\
\text { ilicitude do art. } 47, \S 2^{\circ} \text {, da IN/SRF n. } \\
247 / 2002 \text {, nessa extensão. } \\
\end{array}$ & REsp 1353111/RS & $23 / 09 / 2015$ \\
\hline 625 & $\begin{array}{l}\text { Questão referente à isenção das } \\
\text { entidades de fiscalização profissional } \\
\text { do preparo de recursos nos feitos que } \\
\text { tramitam no âmbito da Justiça Federal. }\end{array}$ & $\begin{array}{l}\text { O benefício da isenção do preparo, } \\
\text { conferido aos entes públicos previstos } \\
\text { no art. } 4^{\circ} \text {, caput, da Lei } 9.289 / 1996 \text {, é } \\
\text { inaplicável aos Conselhos de } \\
\text { Fiscalização Profissional. }\end{array}$ & REsp 1338247/RS & $10 / 10 / 2012$ \\
\hline 626 & $\begin{array}{l}\text { Questão referente ao termo inicial do } \\
\text { benefício aposentadoria por invalidez, } \\
\text { deferido na via judicial e sem } \\
\text { requerimento administrativo anterior, } \\
\text { deve ser fixado na data do laudo } \\
\text { médico-pericial. }\end{array}$ & $\begin{array}{l}\text { A citação válida informa o litígio, } \\
\text { constitui em mora a autarquia } \\
\text { previdenciária federal e deve ser } \\
\text { considerada como termo inicial para a } \\
\text { implantação da aposentadoria por } \\
\text { invalidez concedida na via judicial } \\
\text { quando ausente a prévia postulação } \\
\text { administrativa. }\end{array}$ & REsp 1369165/SP & $26 / 02 / 2014$ \\
\hline 628 & $\begin{array}{l}\text { Questiona se o transcurso do prazo } \\
\text { prescricional previsto no artigo } 61 \text { da } \\
\text { Lei do Cheque não impõe a perda da } \\
\text { pretensão, pois, embora a ação } \\
\text { monitória não ostente natureza } \\
\text { cambial, o cheque prescrito serve } \\
\text { como prova escrita do crédito oriundo } \\
\text { relação causal, que, para } \\
\text { admissibilidade da ação, não se } \\
\text { submete ao mesmo prazo prescricional } \\
\text { da obrigação cambiária. } \\
\end{array}$ & $\begin{array}{l}\text { O prazo para ajuizamento de ação } \\
\text { monitória em face do emitente de } \\
\text { cheque sem força executiva é } \\
\text { quinquenal, a contar do dia seguinte à } \\
\text { data de emissão estampada na cártula. }\end{array}$ & REsp 1101412/SP & $11 / 12 / 2013$ \\
\hline 630 & $\begin{array}{l}\text { Discute a possibilidade de } \\
\text { redirecionamento da execução fiscal } \\
\text { contra o diretor da empresa executada, } \\
\text { por dívida de natureza não tributária, } \\
\text { diante de indícios de dissolução } \\
\text { irregular, nos termos da legislação } \\
\text { civil. }\end{array}$ & $\begin{array}{l}\text { Em execução fiscal de dívida ativa } \\
\text { tributária ou não-tributária, dissolvida } \\
\text { irregularmente a empresa, está } \\
\text { legitimado o redirecionamento ao } \\
\text { sócio-gerente. }\end{array}$ & REsp 1371128/RS & $10 / 09 / 2014$ \\
\hline 631 & $\begin{array}{l}\text { SERVIDOR PÚBLICO FEDERAL. } \\
\text { DOCENTE. CARREIRA DO } \\
\text { MAGISTÉRIO DE ENSINO } \\
\text { BÁSICO, TÉCNICO E } \\
\text { TECNOLÓGICO. PROGRESSÃO } \\
\text { FUNCIONAL. LEI 11.784/08. } \\
\text { CONDIÇÃO DE EFICÁCIA. } \\
\text { NECESSIDADE DE } \\
\text { REGULAMENTAÇÃO. LEI } \\
\text { 11.344/06. }\end{array}$ & $\begin{array}{l}\text { À luz do art. } 120, \S 5^{\circ} \text {, da Lei n. } \\
11.784 / 2008 \text {, até que fosse publicado } \\
\text { o regulamento, as regras de } \\
\text { progressão dos docentes da carreira } \\
\text { do magistério básico, técnico e } \\
\text { tecnológico federal seriam regidas } \\
\text { pelas disposições da anterior Lei n. } \\
11.344 / 2006 \text {, que previa duas } \\
\text { possibilidades de progressão: por } \\
\text { interstício, com avaliação; e por } \\
\text { titulação, sem observância do } \\
\text { interstício. }\end{array}$ & REsp 1343128/SC & $12 / 06 / 2013$ \\
\hline
\end{tabular}


633 Discute-se a legalidade da imposição de honorários advocatícios de sucumbência à parte que renuncia ao direito ou desiste da ação, na forma do art. $6^{\circ}, \S 1^{\circ}$, da Lei $11.941 / 2009$, para os fins de aderir ao parcelamento tributário regido por esse diploma legal.

34 Discute-se a inclusão do ISS na base de cálculo da COFINS/PIS.

36 Cinge-se a discussão em saber se a orientação jurisprudencial já sedimentada nesta Corte de que "as execuções fiscais relativas a débitos iguais ou inferiores a $\mathrm{R} \$ 10.000,00$ (dez mil reais) devem ter seus autos arquivados, sem baixa na distribuição" deve ser estendida aos executivos fiscais movidos pelas autarquias federais.

637 Discute-se a ordem na qual os créditos resultantes de honorários advocatícios devem ser satisfeitos no processo falimentar.

638 Controvérsia acerca da possibilidade de reconhecimento do período de trabalho rural anterior ao documento mais antigo juntado como início de prova material.

640 Discute-se a possibilidade de concessão de benefício previdenciário ou benefício assistencial, no valor de um salário mínimo, recebido por idoso ou deficiente que faça parte do núcleo familiar, não deve ser considerado na aferição da renda per capita prevista no artigo $20, \S 3^{\circ}$, da Lei n. 8.742/93 ante a interpretação do que dispõe o artigo 34, parágrafo único, da Lei n. 10.741/03 (Estatuto do Idoso).

641 Discussão: se o prazo para ajuizamento ação monitória fundada em nota promissória prescrita é o previsto no artigo $206, \S 5^{\circ}$, I, do Código Civil, pois, em que pese a prescrição, constitui instrumento
O artigo $6^{\circ}, \S 1^{\circ}$, da Lei $n^{\circ} 11.941$, de 2009, só dispensou dos honorários advocatícios o sujeito passivo que desistir de ação judicial em que requeira 'o restabelecimento de sua opção ou a sua reinclusão em outros parcelamentos'. Nas demais hipóteses, à míngua de disposição legal em sentido contrário, aplica-se o artigo 26, caput, do Código de Processo Civil, que determina o pagamento dos honorários advocatícios pela parte que desistiu do feito.

$\mathrm{O}$ valor suportado pelo beneficiário do serviço, nele incluindo a quantia referente ao ISSQN, compõe o conceito de receita ou faturamento para fins de adequação à hipótese de incidência do PIS e da COFINS.

$\mathrm{O}$ disposto no art. 20 da Lei $\mathrm{n}$. $10.522 / 2002$ não se aplica às execuções de créditos das autarquias federais cobrados pela ProcuradoriaGeral Federal.

I -os créditos resultantes de

honorários advocatícios têm natureza alimentar e equiparam-se aos trabalhistas para efeito de habilitação em falência, seja pela regência do Decreto-Lei n. 7.661/1945, seja pela forma prevista na Lei n. 11.101/2005, observado o limite de valor previsto no artigo 83 , inciso I, do referido Diploma legal. II - são créditos extraconcursais os honorários de advogado resultantes de trabalhos prestados à massa falida, depois do decreto de falência, nos termos dos arts. 84 e 149 da Lei n. 11.101/2005. Mostra-se possível o reconhecimento de tempo de serviço rural anterior ao documento mais antigo, desde que amparado por convincente prova testemunhal, colhida sob contraditório.

Aplica-se o parágrafo único do artigo 34 do Estatuto do Idoso (Lei n. $10.741 / 03$ ), por analogia, a pedido de benefício assistencial feito por pessoa com deficiência a fim de que benefício previdenciário recebido por idoso, no valor de um salário mínimo, não seja computado no cálculo da renda per capita prevista no artigo 20 , $\S 3^{\circ}$, da Lei n. 8.742/93.

O prazo para ajuizamento de ação
monitória em face do emitente de nota promissória sem força executiva é quinquenal, a contar do dia seguinte ao vencimento do título.

\begin{tabular}{|c|c|}
\hline REsp 1353826/SP & $12 / 06 / 2013$ \\
\hline REsp 1330737/SP & $10 / 06 / 2015$ \\
\hline REsp 1343591/MA & $11 / 12 / 2013$ \\
\hline REsp 1152218/RS & $07 / 05 / 2014$ \\
\hline REsp 1348633/SP & $28 / 08 / 2013$ \\
\hline REsp 1355052/SP & $25 / 02 / 2015$ \\
\hline REsp 1262056/SP & $11 / 12 / 2013$ \\
\hline
\end{tabular}




\begin{tabular}{|c|c|c|c|c|}
\hline & $\begin{array}{l}\text { representante de dívida líquida, certa e } \\
\text { exigível. }\end{array}$ & & & \\
\hline 642 & $\begin{array}{l}\text { Questão referente à atividade rural } \\
\text { deve ser comprovada no período } \\
\text { imediatamente anterior ao } \\
\text { requerimento. }\end{array}$ & $\begin{array}{l}\text { O segurado especial tem que estar } \\
\text { laborando no campo, quando } \\
\text { completar a idade mínima para se } \\
\text { aposentar por idade rural, momento } \\
\text { em que poderá requerer seu benefício. } \\
\text { Ressalvada a hipótese do direito } \\
\text { adquirido, em que o segurado } \\
\text { especial, embora não tenha requerido } \\
\text { sua aposentadoria por idade rural, } \\
\text { preenchera de forma concomitante, no } \\
\text { passado, ambos os requisitos carência } \\
\text { e idade. }\end{array}$ & REsp 1354908/SP & $09 / 09 / 2015$ \\
\hline 643 & $\begin{array}{l}\text { Discussão acerca da possibilidade de } \\
\text { manutenção de pensão por morte a } \\
\text { filho maior de } 21 \text { anos e não inválido. }\end{array}$ & $\begin{array}{l}\text { Não há falar em restabelecimento da } \\
\text { pensão por morte ao beneficiário, } \\
\text { maior de } 21 \text { anos e não inválido, } \\
\text { diante da taxatividade da lei } \\
\text { previdenciária, porquanto não é dado } \\
\text { ao Poder Judiciário legislar } \\
\text { positivamente, usurpando função do } \\
\text { Poder Legislativo. }\end{array}$ & REsp 1369832/SP & $12 / 06 / 2013$ \\
\hline 644 & $\begin{array}{l}\text { Discussão acerca da possibilidade ou } \\
\text { não de concessão de aposentadoria por } \\
\text { tempo de serviço/contribuição a } \\
\text { trabalhador urbano mediante o } \\
\text { cômputo de atividade rural com } \\
\text { registro em carteira profissional em } \\
\text { período anterior ao advento da Lei } \\
8.213 / 1991 \text { para efeito da carência } \\
\text { exigida no art. } 142 \text { da Lei de } \\
\text { Benefícios. }\end{array}$ & $\begin{array}{l}\text { APOSENTADORIA POR TEMPO } \\
\text { DE SERVIÇO. AVERBAÇÃO DE } \\
\text { TRABALHO RURAL COM } \\
\text { REGISTRO EM CARTEIRA } \\
\text { PROFISSIONAL PARA EFEITO DE } \\
\text { CARÊNCIA. POSSIBILIDADE. (...) } \\
\text { Mostra-se incontroverso nos autos } \\
\text { que o autor foi contratado por } \\
\text { empregador rural, com registro em } \\
\text { carteira profissional desde } 1958, \text { razão } \\
\text { pela qual não há como responsabilizá- } \\
\text { lo pela comprovação do recolhimento } \\
\text { das contribuições. }\end{array}$ & REsp 1352791/SP & $27 / 11 / 2013$ \\
\hline 645 & $\begin{array}{l}\text { Discussão acerca da possibilidade ou } \\
\text { não de aplicar o prazo decadencial } \\
\text { previsto no art. } 103 \text { da Lei } 8.213 / 91 \\
\text { aos casos de desaposentação. }\end{array}$ & $\begin{array}{l}\text { A norma extraída do caput do art. } 103 \\
\text { da Lei } 8.213 / 91 \text { não se aplica às } \\
\text { causas que buscam o reconhecimento } \\
\text { do direito de renúncia à } \\
\text { aposentadoria, mas estabelece prazo } \\
\text { decadencial para o segurado ou seu } \\
\text { beneficiário postular a revisão do ato } \\
\text { de concessão do benefício, o qual, se } \\
\text { modificado, importará em pagamento } \\
\text { retroativo, diferente do que se dá na } \\
\text { desaposentação. }\end{array}$ & REsp 1348301/SC & $27 / 11 / 2013$ \\
\hline 646 & $\begin{array}{l}\text { DIREITO PENAL. ART. } 307 \text { DO CP. } \\
\text { PRISÃO EM FLAGRANTE. FALSA } \\
\text { IDENTIFICAÇÃO PERANTE } \\
\text { AUTORIDADE POLICIAL. } \\
\text { AUTODEFESA. INEXISTÊNCIA. } \\
\text { TIPICIDADE DA CONDUTA DE } \\
\text { FALSA IDENTIDADE. } \\
\end{array}$ & $\begin{array}{l}\text { É típica a conduta de atribuir-se falsa } \\
\text { identidade perante autoridade policial, } \\
\text { ainda que em situação de alegada } \\
\text { autodefesa (art. } 307 \text { do CP). }\end{array}$ & REsp 1362524/MG & $23 / 10 / 2013$ \\
\hline 647 & $\begin{array}{l}\text { Questão referente à possibilidade, ou } \\
\text { não, de profissional formado no curso } \\
\text { de três anos de educação física, } \\
\text { licenciatura plena, exercer a sua } \\
\text { profissão em toda e qualquer área } \\
\text { relaciona à educação física, sem a } \\
\text { restrição imposta pelo conselho } \\
\text { Regional de Educação Física do } \\
\text { Estado de São Paulo. }\end{array}$ & $\begin{array}{l}\text { Ao profíssional formado em educação } \\
\text { física, na modalidade licenciatura de } \\
\text { graduação plena, somente é permitido } \\
\text { atuar na educação básica, sendo-lhe } \\
\text { defeso o exercício da profissão na } \\
\text { área não formal. }\end{array}$ & REsp 1361900/SP & $12 / 11 / 2014$ \\
\hline
\end{tabular}


648 Discussão envolvendo ação cautelar de exibição de documentos, em que se questiona o interesse de agir da parte, alegando-se que o pedido de exibição de documentos deveria ser feito no bojo da própria ação principal.
49 Questão referente à legitimidade ou ilegitimidade da pessoa jurídica, originariamente acionada, para interpor recurso contra $\mathrm{o}$ redirecionamento da execução contra

650 Questão relativa ao pagamento do "Benefício Especial de Renda Certa" exclusivamente para os aposentados que, no período de atividade, completaram o mínimo de 360 contribuições.

651 Questão referente à possibilidade de se dispensar a juntada da certidão de intimação da decisão agravada para a formação do agravo de instrumento, nos casos em que há vista pessoal à Fazenda Nacional. os sócios.

A propositura de ação cautelar de exibição de documentos bancários (cópias e segunda via de documentos) é cabível como medida preparatória a fim de instruir a ação principal, bastando a demonstração da existência de relação jurídica entre as partes, a comprovação de prévio pedido à instituição financeira não atendido em prazo razoável, e o pagamento do custo do serviço conforme previsão contratual e normatização da autoridade monetária.

A pessoa jurídica não tem legitimidade para interpor recurso no interesse do sócio.

O benefício especial de renda certa, instituído pela Caixa de Previdência dos Funcionários do Banco do Brasil PREVI, é devido exclusivamente aos assistidos que, no período de atividade, contribuíram por mais de 360 meses (30 anos) para o plano de benefícios.

Considerando a prerrogativa que possui a Fazenda Nacional de ser intimada das decisões, por meio da concessão de vista pessoal e, em atenção ao princípio da instrumentalidade das formas, pode a certidão de concessão de vistas dos autos ser considerada elemento suficiente à demonstração da tempestividade do agravo de instrumento, substituindo a certidão de intimação legalmente prevista.

654 Discute a possibilidade de celebração de cláusula contratual que preveja a capitalização dos juros em periodicidade mensal.

655 PRÁTICA DE CRIME DOLOSO. FALTA GRAVE. DISCUSSÃO ACERCA DA NECESSIDADE DE TRÂNSITO EM JULGADO DA SENTENÇA PENAL CONDENATÓRIA PARA O RECONHECIMENTO DA INFRAÇÃO DISCIPLINAR.

660 O feito em que se busca a concessão de benefício previdenciário deve ser extinto sem julgamento do mérito, por falta de interesse processual, sempre que não houver prévio requerimento ou comunicação desse pedido ao INSS na via administrativa.
A legislação sobre cédulas de crédito rural admite o pacto de capitalização de juros em periodicidade inferior à semestral.

O reconhecimento de falta grave decorrente do cometimento de fato definido como crime doloso no cumprimento da pena prescinde do trânsito em julgado de sentença penal condenatória no processo penal instaurado para apuração do fato.

"(...)a concessão de benefícios previdenciários depende de requerimento administrativo", conforme decidiu o Plenário do Supremo Tribunal Federal, no rito do artigo 543-B do CPC, observadas "as situações de ressalva e fórmula de transição a ser aplicada nas ações já ajuizadas até a conclusão do aludido julgamento (03/9/2014) " julgamento do RE 631.240/MG, sob o
| REsp 1349453/MS |10/12/2014

\begin{tabular}{|l|l|l|}
\hline REsp 1369834/SP & 24/09/2014 \\
& & \\
e & & \\
\hline
\end{tabular}


662 Discussão referente à possibilidade de utilização da tabela do Conselho Nacional de Seguros Privados - CNSP ou da Superintendência de Seguros Privados - SUSEP para se estabelecer a proporcionalidade da indenização, nos casos de acidentes ocorridos anteriormente à entrada em vigor da Medida Provisória $n^{\circ} 451,15$ de dezembro de 2008, convertida na Lei 11.945/09.

666 Discussão acerca da validade da cláusula de contrato de planta comunitária de telefonia - PCT que isenta a companhia de restituir ao consumidor o valor investido ou de subscrever-lhe ações.

667 Discussão sobre a possibilidade de ser dispensada a fase de liquidação de sentença nas demandas por complementação de ações.

668 Discussão sobre o termo inicial da prescrição nas demandas por indenização do seguro DPVAT nos casos de invalidez permanente da vítima.

669 Discussão: possibilidade de cumulação de dividendos e juros sobre capital próprio.

670 Possibilidade de inclusão de juros sobre capital próprio nos cálculos exequendos sem previsão no título executivo judicial.

671 Discussão: atribuição do encargo de antecipar os honorários periciais ao autor da liquidação de sentença, no caso de perícia determinada de ofício.

672 Possibilidade de atribuição do encargo ao réu, na hipótese em que o autor seja beneficiário da gratuidade da justiça.

673 Discussão: necessidade de indicação expressa do valor entendido como correto, no caso de impugnação fundada na tese de excesso de execução.

674 Discussão: possibilidade de cancelamento da distribuição da impugnação ao cumprimento de sentença no caso de não recolhimento das custas no prazo de 30 dias.
Validade da utilização de tabela do CNSP para se estabelecer a proporcionalidade da indenização ao grau de invalidez, na hipótese de sinistro anterior a 16/12/2008, data da entrada em vigor da Medida Provisória 451/08.

\section{É válida, no sistema de planta} comunitária de telefonia - PCT, a previsão contratual ou regulamentar que desobrigue a companhia de subscrever ações em nome do consumidor ou de lhe restituir o valor investido.

O cumprimento de sentença condenatória de complementação de ações dispensa, em regra, a fase de liquidação de sentença.

O termo inicial do prazo prescricional, na ação de indenização, é a data em que o segurado teve ciência inequívoca do caráter permanente da invalidez.

\section{Cabimento da cumulação de} dividendos e juros sobre capital próprio nas demandas por complementação de ações de empresas de telefonia.

Descabimento da inclusão dos dividendos ou dos juros sobre capital próprio no cumprimento da sentença condenatória à complementação de ações sem expressa previsão no título executivo.

Na liquidação por cálculos do credor, descabe transferir do exequente para $o$ executado o ônus do pagamento de honorários devidos ao perito que elabora a memória de cálculos.

Se o credor for beneficiário da gratuidade da justiça, pode-se determinar a elaboração dos cálculos pela contadoria judicial. Na hipótese do art. 475-L, $\S 2^{\circ}$, do CPC, é indispensável apontar, na petição de impugnação ao cumprimento de sentença, a parcela incontroversa do débito, bem como as incorreções encontradas nos cálculos do credor, sob pena de rejeição liminar da petição, não se admitindo emenda à inicial.

Cancela-se a distribuição da impugnação ao cumprimento de sentença ou dos embargos à execução na hipótese de não recolhimento das custas no prazo de 30 dias, independentemente de prévia intimação da parte.

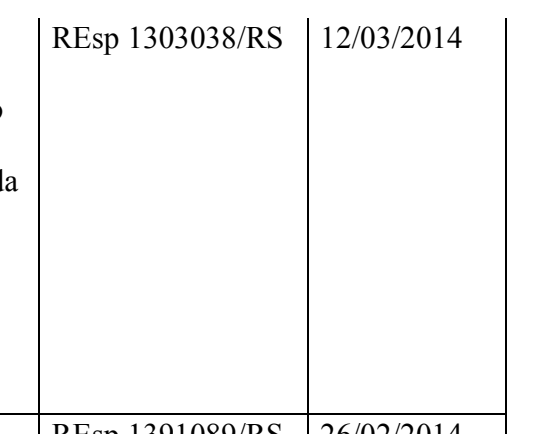

\begin{tabular}{|l|l|}
\hline REsp 1391089/RS & 26/02/2014 \\
& \\
& \\
\hline
\end{tabular}

\begin{tabular}{|l|l|}
\hline REsp 1387249/SC & 26/02/2014 \\
& \\
\hline
\end{tabular}


675 Discussão: (i) possibilidade de cancelamento da distribuição da impugnação ao cumprimento de sentença no caso de não recolhimento das custas no prazo de 30 dias; (ii) necessidade de prévia intimação da parte impugnante.

676 Discussão: (i) possibilidade de cancelamento da distribuição da impugnação ao cumprimento de sentença no caso de não recolhimento das custas no prazo de 30 dias; (ii) necessidade de prévia intimação da parte impugnante; (iii) efeitos do recolhimento efetuado após o prazo de 30 dias, mas antes do efetivo cancelamento da distribuição.

677 Discussão sobre a responsabilidade do devedor pelo pagamento de juros de mora e correção monetária sobre os valores depositados em juízo na fase de execução.

678 Discussão: aplicação de índices de deflação na correção monetária de crédito oriundo de título executivo judicial.

680 Questão referente à ação indenizatória por danos materiais e morais promovida por pescadores em razão de acidente ambiental ocorrido no rio Sergipe, em que se discute a legitimidade processual do autor da ação.

81 Questão referente à ação indenizatória por danos materiais e morais promovida por pescadores em razão de acidente ambiental ocorrido no rio Sergipe, em que se discute a aplicabilidade da Teoria do Risco Integral.

683 Questão referente à ação indenizatória por danos morais promovida por pescadores em razão de acidente ambiental ocorrido no rio Sergipe, em que se discute os valores arbitrados a título de dano moral.
Cancela-se a distribuição da impugnação ao cumprimento de sentença ou dos embargos à execução na hipótese de não recolhimento das custas no prazo de 30 dias, independentemente de prévia intimação da parte.

Não se determina o cancelamento da distribuição se o recolhimento das custas, embora intempestivo, estiver comprovado nos autos.

Na fase de execução, o depósito judicial do montante (integral ou parcial) da condenação extingue a obrigação do devedor, nos limites da quantia depositada.

Aplicam-se os índices de deflação na correção monetária de crédito oriundo de título executivo judicial, preservado o seu valor nominal.

Para demonstração da legitimidade para vindicar indenização por dano ambiental que resultou na redução da pesca na área atingida, o registro de pescador profissional e a habilitação ao benefício do seguro-desemprego, durante o período de defeso, somados a outros elementos de prova que permitam o convencimento do magistrado acerca do exercício dessa atividade, são idôneos à sua comprovação.

A responsabilidade por dano ambiental é objetiva, informada pela teoria do risco integral, sendo o nexo de causalidade o fator aglutinante que permite que o risco se integre na unidade do ato, sendo descabida a invocação, pela empresa responsável pelo dano ambiental, de excludentes de responsabilidade civil para afastar a sua obrigação de indenizar.

Em vista das circunstâncias específicas e homogeneidade dos efeitos do dano ambiental verificado no ecossistema do rio Sergipe afetando significativamente, por cerca de seis meses, o volume pescado e a renda dos pescadores na região afetada -, sem que tenha sido dado amparo pela poluidora para mitigação dos danos morais experimentados e demonstrados por aqueles que extraem o sustento da pesca profissional, não se justifica, em sede de recurso especial, a revisão do quantum arbitrado, a título de compensação por danos morais, em R \$ 3.000,00 (três mil reais).

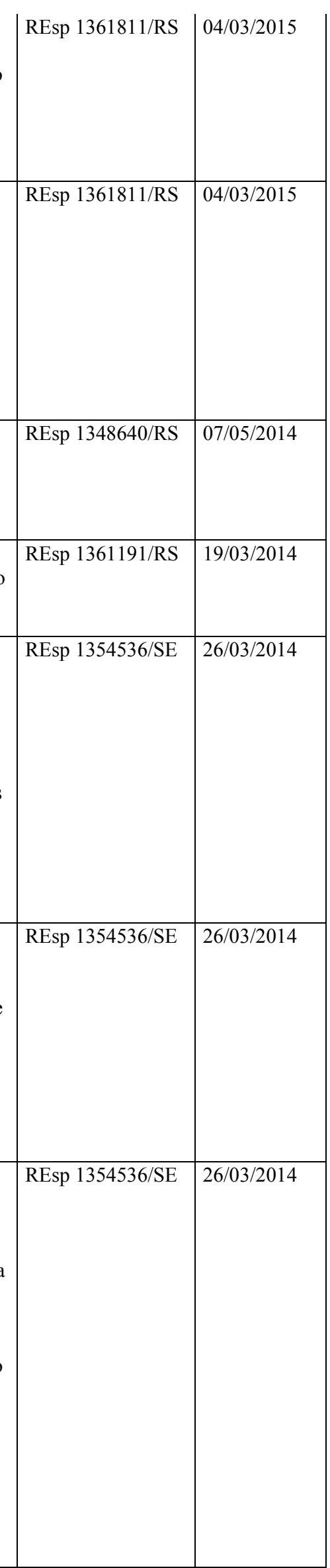


686 Questão atinente à obrigatoriedade de chamamento ao processo (art. 77, III, do CPC) da União nas demandas que envolvem a pretensão de fornecimento de medicamentos.

687 Discussão acerca da incidência de contribuição previdenciária sobre a seguinte verba trabalhista: horas extras.

688 Discussão acerca da incidência de contribuição previdenciária sobre a seguinte verba trabalhista: adicional noturno.

689 Discussão acerca da incidência de contribuição previdenciária sobre a seguinte verba trabalhista: adicional de periculosidade.

690 Discussão: se a declaração de inconstitucionalidade do art. $3^{\circ}, \S 1^{\circ}$, da Lei 9.718/1998, pelo STF, afasta automaticamente a presunção de certeza e de liquidez da CDA constituída sobre essa base legal, de modo a autorizar a extinção de ofício da Execução Fiscal.

693 Questionamento acerca da competência para julgamento das ações que objetivam discutir contrato firmando entre o segurado e a Fundação Rede Ferroviária de Seguridade Social - REFER, entidade fechada de previdência privada, instituída pela extinta Rede Ferroviária de Seguridade Social - RFFSA, sociedade de economia mista sucedida pela União.

694 Questão referente à possibilidade de reconhecimento de tempo especial por exposição ao agente ruído em nível inferior a $90 \mathrm{~dB}$ no período compreendido entre 5.3.1997 e 18.11.2003, por força da aplicação retroativa do limite de $85 \mathrm{~dB}$ estipulado pelo Decreto 4.882/2003 ao Anexo IV do Decreto 3.048/1999.

696 Discussão quanto à aplicação imediata do art. $8^{\circ}$ da Lei $n^{\circ} 12.514 / 11$ ("Os Conselhos não executarão judicialmente dívidas referentes a anuidades inferiores a 4 (quatro) vezes o valor cobrado anualmente da pessoa física ou jurídica inadimplente ") às execuções propostas antes de sua entrada em vigor.
O chamamento ao processo da União com base no art. 77, III, do CPC, nas demandas propostas contra os demais entes federativos responsáveis para o fornecimento de medicamentos ou prestação de serviços de saúde, não é impositivo, mostrando-se inadequado opor obstáculo inútil à garantia fundamental do cidadão à saúde.

As horas extras e seu respectivo adicional constituem verbas de natureza remuneratória, razão pela qual se sujeitam à incidência de contribuição previdenciária.

\begin{tabular}{|l|l|l}
\hline O adicional noturno constitui verba de & REsp 1358281/SP & 23/04/2014
\end{tabular} natureza remuneratória, razão pela qual se sujeita à incidência de contribuição previdenciária.

$\mathrm{O}$ adicional de periculosidade constitui verba de natureza remuneratória, razão pela qual se sujeita à incidência de contribuição previdenciária

\begin{tabular}{|l|l|l} 
A declaração de inconstitucionalidade & REsp 1386229/PE & 10/08/2016
\end{tabular}
do art. $3^{\circ}, \S 1^{\circ}$, da Lei 9.718/1998, pelo STF, não afasta automaticamente a presunção de certeza e de liquidez da CDA, motivo pelo qual é vedado extinguir de ofício, por esse motivo, a Execução Fiscal.

A competência para processar e julgar $\quad$ REsp 1183604/MG 11 1/12/2013 as demandas que têm por objeto obrigações decorrentes dos contratos de planos de previdência privada firmados com a Fundação Rede Ferroviária de Seguridade Social (REFER) é da Justiça Estadual.

O limite de tolerância para
configuração da especialidade do tempo de serviço para o agente ruído deve ser de $90 \mathrm{~dB}$ no período de 6.3.1997 a 18.11.2003, conforme Anexo IV do Decreto 2.172/1997 e Anexo IV do Decreto 3.048/1999, sendo impossível aplicação retroativa do Decreto 4.882/2003, que reduziu o patamar para $85 \mathrm{~dB}$, sob pena de ofensa ao art. $6^{\circ}$ da LINDB (exLICC).

É inaplicável o art. $8^{\circ}$ da Lei ${ }^{\circ}$ 12.514/11 ('Os Conselhos não executarão judicialmente dívidas referentes a anuidades inferiores a 4 (quatro) vezes o valor cobrado anualmente da pessoa física ou jurídica inadimplente') às execuções propostas antes de sua entrada em vigor.

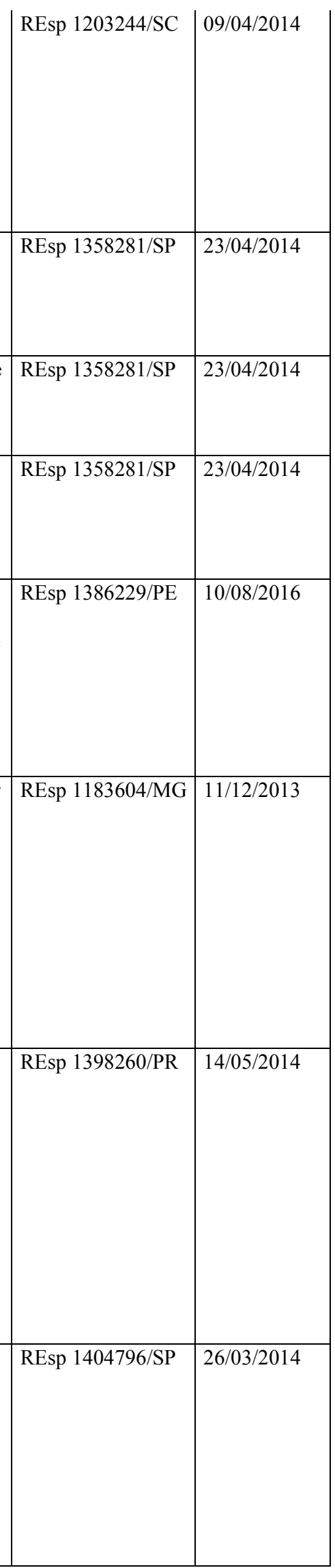


697 Discussão: prescindibilidade da certidão de intimação da decisão agravada para a comprovação da tempestividade do recurso.

A ausência da cópia da certidão de intimação da decisão agravada não é óbice ao conhecimento do Agravo de Instrumento quando, por outros meios inequívocos, for possível aferir a tempestividade do recurso, em atendimento ao princípio da instrumentalidade das formas.

698 Discussão quanto ao cabimento da aplicação de multa em Embargos de Declaração que visavam suprir o requisito do prequestionamento viabilizador do Recurso Especial, nos termos da Súmula 98 do Superior Tribunal de Justiça.

702 A falência da empresa executada fora decretada antes do ajuizamento da execução fiscal; a discussão é sobre a legitimidade passiva da sociedade $\mathrm{e}$ incidência, ou não, da Súmula 392/STJ.

Caracterizam-se como protelatórios os embargos de declaração que visam rediscutir matéria já apreciada $\mathrm{e}$ decidida pela Corte de origem em conformidade com súmula do STJ ou STF ou, ainda, precedente julgado pelo rito dos artigos 543-C e 543-B, do CPC.

A mera decretação da quebra não implica extinção da personalidade jurídica do estabelecimento empresarial. Ademais, a massa falida tem exclusivamente personalidade judiciária, sucedendo a empresa em todos os seus direitos e obrigações. Em consequência, o ajuizamento contra a pessoa jurídica, nessas condições, constitui mera irregularidade, sanável nos termos do art. 284 do $\mathrm{CPC}$ e do art. $2^{\circ}, \S 8^{\circ}$, da Lei 6.830/1980.

703 A falência da empresa executada fora decretada antes do ajuizamento da execução fiscal; a discussão é sobre a legitimidade passiva da sociedade e incidência, ou não, da Súmula 392/STJ.

O entendimento de que o ajuizamento contra a pessoa jurídica cuja falência foi decretada antes do ajuizamento da referida execução fiscal "constitui mera irregularidade, sanável nos termos do art. 284 do CPC e do art. $2^{\circ}, \S 8^{\circ}$, da Lei $6.830 / 1980$ não viola a orientação fixada pela Súmula 392 do Superior Tribunal Justiça, mas tão somente insere o equívoco ora debatido na extensão do que se pode compreender por 'erro material ou formal', e não como 'modificação do sujeito passivo da execução', expressões essas empregadas pelo referido precedente sumular.

704 Discussão acerca da forma de cálculo A aposentadoria por invalidez da aposentadoria por invalidez oriunda da conversão do auxílio-doença, previsto no art. 29 , II e $\S 5^{\circ}$, da Lei $8.213 / 91$, com a redação dada pela Lei 9.876/99.

decorrente da conversão de auxíliodoença, sem retorno do segurado ao trabalho, será apurada na forma estabelecida no art. $36, \S 7^{\circ}$, do Decreto 3.048/99, segundo o qual a renda mensal inicial - RMI da aposentadoria por invalidez oriunda de transformação de auxílio-doença será de cem por cento do salário-debenefício que serviu de base para o cálculo da renda mensal inicial do auxílio-doença, reajustado pelos mesmos índices de correção dos benefícios em geral.

705 Possibilidade de cominação de astreintes na determinação incidental de exibição de documentos durante a fase de cumprimento de sentença.

Descabimento de multa cominatória na exibição, incidental ou autônoma, de documento relativo a direito disponível.

706 Possibilidade de rediscussão do A decisão que comina astreintes não cabimento das astreintes após preclusão do decisum que as cominou. preclui, não fazendo tampouco coisa julgada.

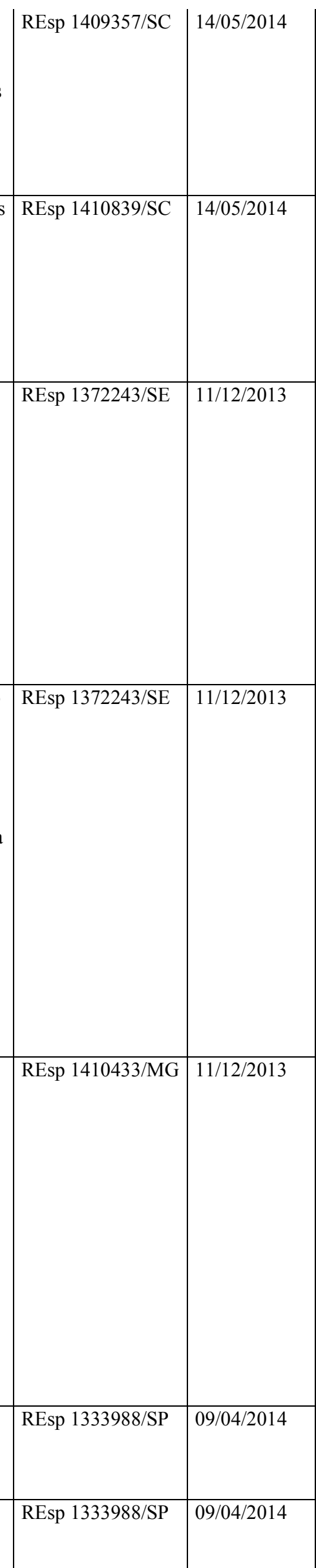


707 Questão referente à responsabilidade civil em caso de acidente ambiental (rompimento de barragem) ocorrido nos Municípios de Miraí e Muriaé, Estado de Minas Gerais.

a) a responsabilidade por dano ambiental é objetiva, informada pela teoria do risco integral, sendo o nexo de causalidade o fator aglutinante que permite que o risco se integre na unidade do ato, sendo descabida a invocação, pela empresa responsável pelo dano ambiental, de excludentes de responsabilidade civil para afastar sua obrigação de indenizar; b) em decorrência do acidente, a empresa deve recompor os danos materiais e morais causados; c) na fixação da indenização por danos morais, recomendável que o arbitramento seja feito caso a caso e com moderação, proporcionalmente ao grau de culpa, ao nível socioeconômico do autor, e, ainda, ao porte da empresa, orientando-se o juiz pelos critérios sugeridos pela doutrina e jurisprudência, com razoabilidade, valendo-se de sua experiência e bom senso, atento à realidade da vida e às peculiaridades de cada caso, de modo a que, de um lado, não haja enriquecimento sem causa de quem recebe a indenização e, de outro, haja efetiva compensação pelos danos morais experimentados por aquele que fora lesado.

708 Discussão referente à penhora do bem de família no contrato de locação quando decorrente de fiança locatícia.

709 Estabelecer se a prática de falta grave importaria na interrupção dos prazos para a obtenção de benefícios na execução penal, modificando, assim, a data-base da sua contagem.
E legítima a penhora de apontado bem de família pertencente a fiador de contrato de locação, ante o que dispõe o art. $3^{\circ}$, inciso VII, da Lei $n$. $8.009 / 1990$

1. A prática de falta grave interrompe o prazo para a progressão de regime, acarretando a modificação da database e o início de nova contagem do lapso necessário para o preenchimento do requisito objetivo.2. Em se tratando de livramento condicional, não ocorre a interrupção do prazo pela prática de falta grave. Aplicação da Súmula 441/STJ.3. Também não é interrompido automaticamente o prazo pela falta grave no que diz respeito à comutação de pena ou indulto, mas a sua concessão deverá observar o cumprimento dos requisitos previstos no decreto presidencial pelo qual foram instituídos.

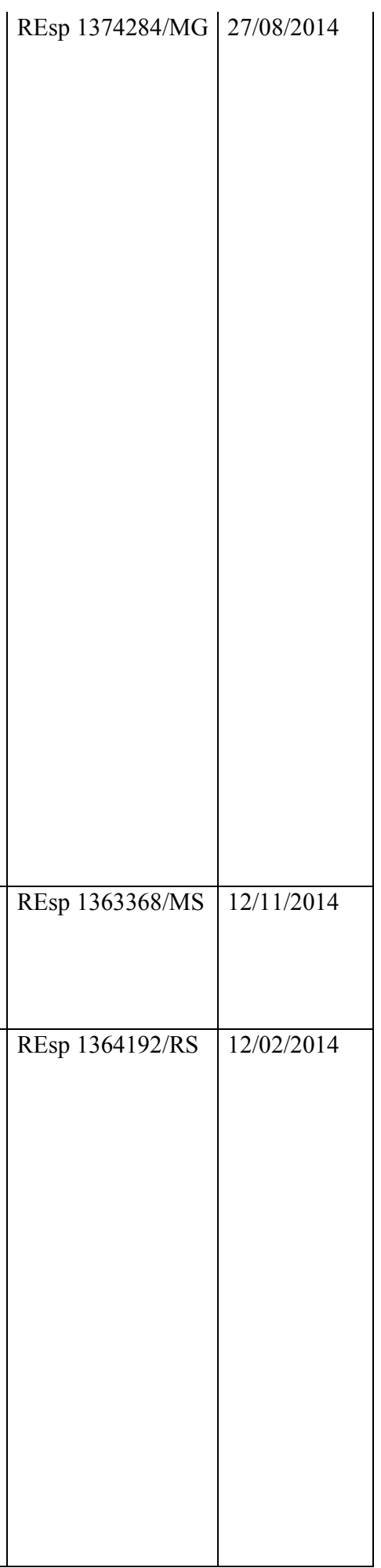


710 Discussão acerca da natureza dos sistemas de scoring e a possibilidade de violação a princípios e regras do Código de Defesa do Consumidor capaz de gerar indenização por dano moral.
711 Discute-se a aplicação de juros progressivos nas contas de FGTS dos trabalhadores avulsos.

714 Cinge-se o debate trazido nos autos em saber se, para que o juiz determine a indisponibilidade dos bens e direitos do devedor, na forma do art. 185-A do CTN, faz-se necessária a comprovação do exaurimento dos meios disponíveis para localização de bens penhoráveis por parte do credor. Não se trata, simplesmente, da penhora on-line, mas da necessidade de esgotamento das diligências para a adoção das medidas previstas no art. 185-A do CTN.
I - O sistema "credit scoring" é um método desenvolvido para avaliação do risco de concessão de crédito, a partir de modelos estatísticos, considerando diversas variáveis, com atribuição de uma pontuação ao consumidor avaliado (nota do risco de crédito).II - Essa prática comercial é lícita, estando autorizada pelo art. $5^{\circ}$, IV, e pelo art. $7^{\circ}$, I, da Lei $n$.

12.414/2011 (lei do cadastro positivo).III - Na avaliação do risco de crédito, devem ser respeitados os limites estabelecidos pelo sistema de proteção do consumidor no sentido da tutela da privacidade e da máxima transparência nas relações negociais, conforme previsão do CDC e da Lei n. 12.414/2011.IV - Apesar de desnecessário o consentimento do consumidor consultado, devem ser a ele fornecidos esclarecimentos, caso solicitados, acerca das fontes dos dados considerados (histórico de crédito), bem como as informações pessoais valoradas. $\mathrm{V}$ - O desrespeito aos limites legais na utilização do sistema "credit scoring", configurando abuso no exercício desse direito (art. 187 do CC), pode ensejar a responsabilidade objetiva e solidária do fornecedor do serviço, do responsável pelo banco de dados, da fonte e do consulente (art. 16 da Lei n. 12.414/2011) pela ocorrência de danos morais nas hipóteses de utilização de informações excessivas ou sensíveis (art. $3^{\circ}, \S 3^{\circ}$, I e II, da Lei n. 12.414/2011), bem como nos casos de comprovada recusa indevida de crédito pelo uso de dados incorretos ou desatualizados.

Não se aplica a taxa progressiva de juros às contas vinculadas ao FGTS de trabalhadores qualificados como avulsos.

A indisponibilidade de bens e direitos autorizada pelo art. 185-A do CTN depende da observância dos seguintes requisitos: (i) citação do devedor tributário; (ii) inexistência de pagamento ou apresentação de bens à penhora no prazo legal; e (iii) a não localização de bens penhoráveis após esgotamento das diligências realizadas pela Fazenda, caracterizado quando houver nos autos (a) pedido de acionamento do Bacen Jud e consequente determinação pelo magistrado e (b) a expedição de ofícios aos registros públicos do domicílio do executado e ao Departamento Nacional ou Estadual de Trânsito - DENATRAN ou DETRAN.

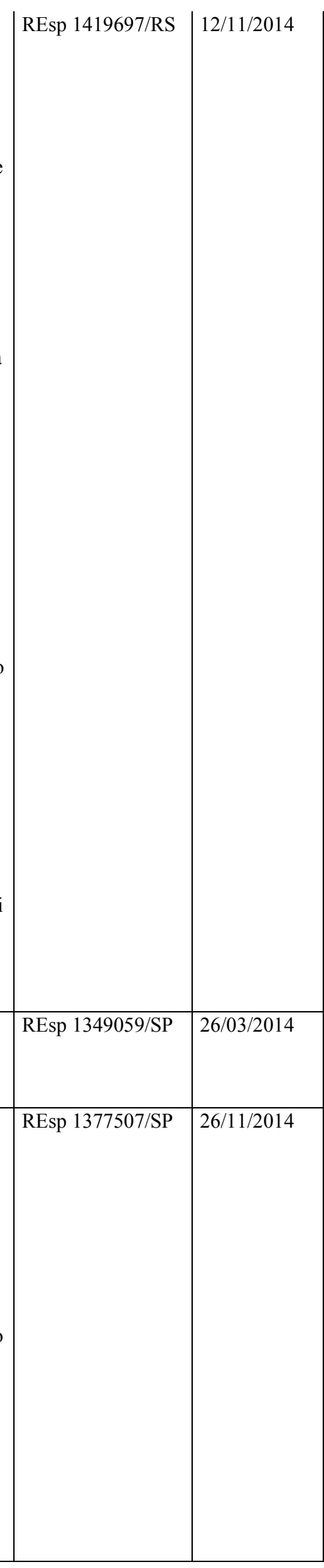


715 Discussão quanto à competência do Conselho Regional de Farmácia do Estado de Minas Gerais - CRF/MG para fiscalizar e autuar estabelecimentos que exercem atividade farmacêutica sem a presença de responsável técnico durante todo o horário de funcionamento.
717 Legitimidade do Ministério Público para o ajuizamento de ações de alimentos em benefício de crianças e adolescentes, sobretudo quando se encontram sob o poder familiar de um dos pais - exegese dos arts. 201, inciso III, e 98, inciso II, ambos do Estatuto da Criança e do Adolescente.
720 Possibilidade de saque de conta vinculada ao FGTS por trabalhador que permaneceu fora do sistema, em razão da ocupação de cargo comissionado por mais de três anos.

721 A controvérsia consiste em verificar o cabimento da fixação de honorários advocatícios em Execução promovida sob o rito do art. 730 do CPC, não embargada contra a Fazenda Pública, na hipótese em que a parte renuncia posteriormente ao excedente previsto no art. 87 do ADCT, para fins de expedição de Requisição de Pequeno Valor (RPV).
Os Conselhos Regionais de Farmácia possuem competência para fiscalização e autuação das farmácias e drogarias, quanto ao cumprimento da exigência de manterem profissional legalmente habilitado (farmacêutico) durante todo o período de funcionamento dos respectivos estabelecimentos, sob pena de incorrerem em infração passível de multa. Inteligência do art. 24 da Lei $n$. 3.820/60, c/c o art. 15 da Lei $n$. $5.991 / 73$.

O Ministério Público tem

legitimidade ativa para ajuizar ação de alimentos em proveito de criança ou adolescente. A legitimidade do Ministério Público independe do exercício do poder familiar dos pais, ou de o menor se encontrar nas situações de risco descritas no art. 98 do Estatuto da Criança e do Adolescente, ou de quaisquer outros questionamentos acerca da existência ou eficiência da Defensoria Pública na comarca.

O trabalhador que teve seu contrato de trabalho suspenso, permanecendo fora do sistema do FGTS em razão do exercício de cargo comissionado por mais de três anos, não possui direito ao levantamento do saldo de FGTS. A renúncia ao valor excedente ao previsto no art. 87 do ADCT, manifestada após a propositura da demanda executiva, não autoriza o arbitramento dos honorários, porquanto, à luz do princípio da causalidade, a Fazenda Pública não provocou a instauração da Execução, uma vez que se revelava inicialmente impositiva a observância do art. 730 CPC, segundo a sistemática do pagamento de precatórios. Como não foram opostos Embargos à Execução, tem, portanto, plena aplicação o art. $1^{\circ}$-D da Lei 9.494/1997.

722 Necessidade de, na busca e apreensão de bem alienado fiduciariamente, ser paga a integralidade do débito para caracterizar-se a purgação da mora pelo pagamento, não sendo suficiente o pagamento, tão somente, das parcelas vencidas.
Nos contratos firmados na vigência da

Lei n. 10.931/2004, compete ao

devedor, no prazo de 5 (cinco) dias após a execução da liminar na ação de busca e apreensão, pagar a integralidade da dívida - entendida esta como os valores apresentados e comprovados pelo credor na inicial -, sob pena de consolidação da propriedade do bem móvel objeto de alienação fiduciária.

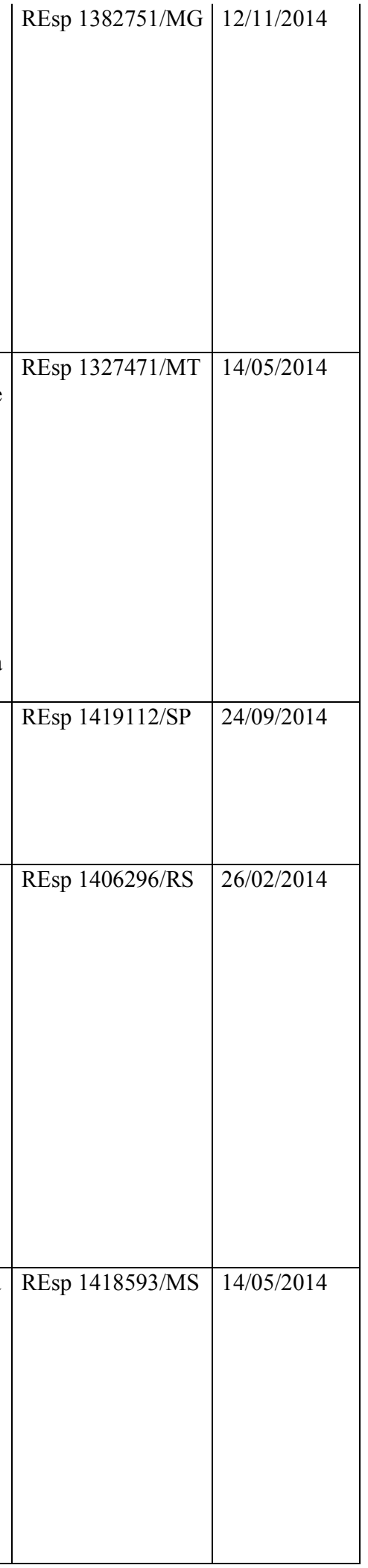


723 Discute se a sentença proferida pelo Juízo da $12^{\mathrm{a}}$ Vara Cível da Circunscrição Especial Judiciária de Brasília/DF na ação civil coletiva $\mathrm{n}$. 1998.01.1.016798-9 - e que condenou o Banco do Brasil ao pagamento de diferenças decorrentes de expurgos inflacionários sobre cadernetas de poupança ocorridos em janeiro de 1989 (Plano Verão) - é aplicável, por força da coisa julgada, indistintamente a todos os detentores de caderneta de poupança do Banco do Brasil, independentemente de sua residência ou domicílio no Distrito Federal, reconhecendo-se ao beneficiário o direito de ajuizar o cumprimento individual da sentença coletiva no Juízo de seu domicílio ou no Distrito Federal.

724 Discute a legitimidade ativa dos poupadores, independentemente de fazerem parte dos quadros associativos individual da sentença coletiva proferida na referida ação civil pública. do IDEC, de ajuizarem o cumprimento

725 Discute se após o pagamento do débito, incumbe ao devedor ou ao credor providenciar o cancelamento do protesto extrajudicial regularmente efetuado, à luz da Lei n. 9.492/1997.

728 Colocação das 'sociedades corretoras de seguros' dentro do bojo de um conjunto maior de 'sociedades corretoras', a fim de que se aplique o art. 18, da Lei n. 10.684/2003.

729 Discute-se a identidade entre as 'sociedades corretoras de seguros' e os 'agentes autônomos de seguros', a fim de que se aplique o art. 18, da Lei $n$. $10.684 / 2003$.

735 Discute se incumbe ao credor, em havendo regular inscrição do nome do devedor em cadastro de órgão de proteção ao crédito, excluir o apontamento efetuado após o pagamento do débito.
A sentença proferida pelo Juízo da $12^{\mathrm{a}}$ Vara Cível da Circunscrição Especial Judiciária de Brasília/DF, na ação civil coletiva $n^{\circ}$ 1998.01.1.016798-9, que condenou o Banco do Brasil ao pagamento de diferenças decorrentes de expurgos inflacionários sobre cadernetas de poupança ocorridos em janeiro de 1989 (Plano Verão), é aplicável, por força da coisa julgada, indistintamente a todos os detentores de caderneta de poupança do Banco do Brasil, independentemente de sua residência ou domicílio no Distrito Federal, reconhecendo-se ao beneficiário o direito de ajuizar o cumprimento individual da sentença coletiva no Juízo de seu domicílio ou no Distrito Federal.

Os poupadores ou seus sucessores

detêm legitimidade ativa - também

por força da coisa julgada -,

independentemente de fazerem parte ou não dos quadros associativos do IDEC, de ajuizarem o cumprimento individual da sentença coletiva proferida na ação civil pública ${ }^{\circ}$ 1998.01.1.016798-9 pelo Juízo da $12^{\mathrm{a}}$ Vara Cível da Circunscrição Especial Judiciária de Brasília/DF.

\begin{tabular}{|l|l} 
REsp 1391198/RS |13/08/2014
\end{tabular}

No regime próprio da Lei $\mathrm{n}$

$9.492 / 1997$, legitimamente protestado

o título de crédito ou outro documento de dívida, salvo inequívoca pactuação em sentido contrário, incumbe ao devedor, após a quitação da dívida, providenciar o cancelamento do protesto.

As 'sociedades corretoras de seguros' estão fora do rol de entidades constantes do art. $22, \S 1^{\circ}$, da Lei $n$. $8.212 / 91$.

Não cabe confundir as "sociedades

corretoras de seguros" com as

"sociedades corretoras de valores mobiliários" (regidas pela Resolução BACEN n. 1.655/89) ou com os "agentes autônomos de seguros privados" (representantes das seguradoras por contrato de agência). As "sociedades corretoras de seguros" estão fora do rol de entidades constantes do art. $22, \S 1^{\circ}$, da Lei n. $8.212 / 91$.

Diante das regras prevista no Código de Defesa do Consumidor, mesmo havendo regular inscrição do nome devedor em cadastro de órgão de proteção ao crédito, após o integral pagamento da dívida, incumbe ao credor requerer a exclusão do registro desabonador, no prazo de 5 (cinco) dias úteis, a contar do primeiro dia útil subsequente à completa disponibilização de numerário 


\begin{tabular}{|c|c|c|c|c|}
\hline & & $\begin{array}{l}\text { necessário à quitação do débito } \\
\text { vencido. }\end{array}$ & & \\
\hline 736 & $\begin{array}{l}\text { Discute se o abono único salarial } \\
\text { previsto em acordo coletivo ou } \\
\text { convenção coletiva de trabalho para os } \\
\text { empregados da ativa deve integrar a } \\
\text { complementação de aposentadoria dos } \\
\text { inativos paga por instituição de } \\
\text { previdência privada. }\end{array}$ & $\begin{array}{l}\text { Nos planos de benefícios de } \\
\text { previdência privada fechada, } \\
\text { patrocinados pelos entes federados - } \\
\text { inclusive suas autarquias, fundações, } \\
\text { sociedades de economia mista e } \\
\text { empresas controladas direta ou } \\
\text { indiretamente -, é vedado o repasse de } \\
\text { abono e vantagens de qualquer } \\
\text { natureza para os benefícios em } \\
\text { manutenção, sobretudo a partir da } \\
\text { vigência da Lei Complementar n. } \\
\text { 108/2001, independentemente das } \\
\text { disposições estatutárias e } \\
\text { regulamentares. }\end{array}$ & REsp 1425326/RS & $28 / 05 / 2014$ \\
\hline 742 & $\begin{array}{l}\text { Discute-se a condenação da parte ré, } \\
\text { em ação individual de indenização, ao } \\
\text { pagamento de danos sociais não } \\
\text { requeridos em favor de terceiro } \\
\text { estranho à lide. }\end{array}$ & $\begin{array}{l}\text { É nula, por configurar julgamento } \\
\text { extra petita, a decisão que condena a } \\
\text { parte ré, de ofício, em ação individual, } \\
\text { ao pagamento de indenização a título } \\
\text { de danos sociais em favor de terceiro } \\
\text { estranho à lide. }\end{array}$ & Rcl $12062 / \mathrm{GO}$ & $12 / 11 / 2014$ \\
\hline 743 & $\begin{array}{l}\text { Possibilidade da execução provisória } \\
\text { da multa diária fixada em sede de } \\
\text { antecipação de tutela nos autos da ação } \\
\text { principal, por se tratar de título judicial } \\
\text { líquido, certo e exigível. }\end{array}$ & $\begin{array}{l}\text { A multa diária prevista no } \S 4^{\circ} \text { do art. } \\
461 \text { do CPC, devida desde o dia em } \\
\text { que configurado o descumprimento, } \\
\text { quando fixada em antecipação de } \\
\text { tutela, somente poderá ser objeto de } \\
\text { execução provisória após a sua } \\
\text { confirmação pela sentença de mérito e } \\
\text { desde que o recurso eventualmente } \\
\text { interposto não seja recebido com } \\
\text { efeito suspensivo. }\end{array}$ & REsp 1200856/RS & $01 / 07 / 2014$ \\
\hline 793 & $\begin{array}{l}\text { Discute se o órgão de proteção ao } \\
\text { crédito tem obrigação de indenizar por } \\
\text { incluir em seus registros elementos } \\
\text { constantes em banco de dados } \\
\text { públicos de cartório de distribuição do } \\
\text { Judiciário. }\end{array}$ & $\begin{array}{l}\text { Diante da presunção legal de } \\
\text { veracidade e publicidade inerente aos } \\
\text { registros do cartório de distribuição } \\
\text { judicial, a reprodução objetiva, fiel, } \\
\text { atualizada e clara desses dados na } \\
\text { base de órgão de proteção ao crédito - } \\
\text { ainda que sem a ciência do } \\
\text { consumidor-, não tem o condão de } \\
\text { ensejar obrigação de reparação de } \\
\text { danos. }\end{array}$ & REsp 1344352/SP & $12 / 11 / 2014$ \\
\hline 794 & $\begin{array}{l}\text { Questão referente à validade, ou não, } \\
\text { de uma só decisão tomada no âmbito } \\
\text { da Justiça Desportiva. }\end{array}$ & $\begin{array}{l}\text { É competente o Juízo do local em que } \\
\text { situada a sede da entidade } \\
\text { organizadora de campeonato } \\
\text { esportivo de caráter nacional para } \\
\text { todos os processos de ações ajuizadas } \\
\text { em vários Juízos e Juizados Especiais, } \\
\text { situados em lugares diversos do país, } \\
\text { questionando a mesma matéria } \\
\text { central, relativa à validade e à } \\
\text { execução de decisões da Justiça } \\
\text { Desportiva, visto que a entidade } \\
\text { esportiva de caráter nacional, } \\
\text { responsável, individual ou } \\
\text { conjuntamente com quaisquer outras } \\
\text { entidades, pela organização (no caso, } \\
\text { a CBF), deve, necessariamente, } \\
\text { inclusive por decisão de ofício, } \\
\text { integrar o pólo passivo das demandas, }\end{array}$ & $\begin{array}{ll}\mathrm{CC} & 133244 / \mathrm{RJ}\end{array}$ & $11 / 06 / 2014$ \\
\hline
\end{tabular}




\begin{tabular}{|c|c|c|c|c|}
\hline & & $\begin{array}{l}\text { sob pena de não vir ela ser ser ela } \\
\text { atingida pelos efeitos subjetivos da } \\
\text { coisa julgada, e de tornar-se o julgado } \\
\text { desprovido de efetividade. }\end{array}$ & & \\
\hline 804 & $\begin{array}{l}\text { Cinge-se a controvérsia a saber até que } \\
\text { data é devido o reajuste de } 3,17 \% \text { nos } \\
\text { vencimentos ou proventos dos } \\
\text { servidores públicos do magistério } \\
\text { superior, tendo em vista a edição da } \\
\text { Lei n. 9.678/98. }\end{array}$ & $\begin{array}{l}\text { O pagamento do reajuste de } 3,17 \% \\
\text { está limitado à data da reestruturação } \\
\text { ou reorganização da carreira, nos } \\
\text { termos do art. } 10 \text { da Medida } \\
\text { Provisória n. } 2.225-45 / 2001 \text {, não } \\
\text { configurando tal marco o advento da } \\
\text { Lei n. } 9.678 \text {, de } 3 \text { de julho de } 1998 \text {, } \\
\text { que estabeleceu a Gratificação de } \\
\text { Estímulo à Docência - GED, uma vez } \\
\text { que esse normativo não reorganizou } \\
\text { ou reestruturou a carreira dos } \\
\text { servidores públicos do magistério } \\
\text { superior lotados em instituições de } \\
\text { ensino dos Ministérios da Educação e } \\
\text { da Defesa. }\end{array}$ & REsp 1371750/PE & $25 / 03 / 2015$ \\
\hline 806 & $\begin{array}{l}\text { Discussão: se o órgão de proteção ao } \\
\text { crédito tem obrigação de indenizar por } \\
\text { incluir em seus registros elementos } \\
\text { constantes em banco de dados público } \\
\text { de cartório de protesto. }\end{array}$ & $\begin{array}{l}\text { Diante da presunção legal de } \\
\text { veracidade e publicidade inerente aos } \\
\text { registros do cartório de protesto, a } \\
\text { reprodução objetiva, fiel, atualizada e } \\
\text { clara desses dados na base de órgão } \\
\text { de proteção ao crédito - ainda que sem } \\
\text { a ciência do consumidor - não tem o } \\
\text { condão de ensejar obrigação de } \\
\text { reparação de danos. }\end{array}$ & REsp 1444469/DF & $12 / 11 / 2014$ \\
\hline 834 & $\begin{array}{l}\text { Questão referente à ação indenizatória } \\
\text { por danos materiais e morais } \\
\text { promovida por pescadores em razão de } \\
\text { acidente ambiental ocorrido no rio } \\
\text { Sergipe, em que se discute os valores } \\
\text { arbitrados a título de reparação por } \\
\text { lucros cessantes e por dano moral. }\end{array}$ & $\begin{array}{l}\text { O dano material somente é } \\
\text { indenizável mediante prova efetiva de } \\
\text { sua ocorrência, não havendo falar em } \\
\text { indenização por lucros cessantes } \\
\text { dissociada do dano efetivamente } \\
\text { demonstrado nos autos; assim, se } \\
\text { durante o interregno em que foram } \\
\text { experimentados os efeitos do dano } \\
\text { ambiental houve o período de 'defeso' } \\
\text { - incidindo a proibição sobre toda } \\
\text { atividade de pesca do lesado -, não há } \\
\text { cogitar em indenização por lucros } \\
\text { cessantes durante essa vedação. }\end{array}$ & REsp 1354536/SE & $26 / 03 / 2014$ \\
\hline 835 & $\begin{array}{l}\text { Discute a validade ou não de cláusula } \\
\text { que estabelece o pagamento de saldo } \\
\text { devedor residual após o término do } \\
\text { pagamento das prestações em contrato } \\
\text { de mútuo imobiliário não coberto pelo } \\
\text { Fundo de Compensação de Variação } \\
\text { Salarial-FCVS. }\end{array}$ & $\begin{array}{l}\text { Nos contratos de financiamento } \\
\text { celebrados no âmbito do SFH, sem } \\
\text { cláusula de garantia de cobertura do } \\
\text { FCVS, o saldo devedor residual } \\
\text { deverá ser suportado pelo mutuário. }\end{array}$ & REsp 1443870/PE & $22 / 10 / 2014$ \\
\hline 869 & $\begin{array}{l}\text { Discute-se a interrupção da prescrição } \\
\text { do direito a pleitear diferenças de } \\
\text { vencimentos a professores do Estado } \\
\text { do Amapá por força do desvio de } \\
\text { função, na hipótese em que foi } \\
\text { ajuizada ação com o mesmo pedido e } \\
\text { causa de pedir pelo Sindicato e a ação } \\
\text { foi extinta sem julgamento do mérito. }\end{array}$ & $\begin{array}{l}\text { "A citação válida em processo extinto } \\
\text { sem julgamento do mérito importa na } \\
\text { interrupção do prazo prescricional, } \\
\text { que volta a correr com o trânsito em } \\
\text { julgado da sentença de extinção do } \\
\text { processo." }\end{array}$ & REsp 1091539/AP & $26 / 11 / 2008$ \\
\hline
\end{tabular}


870 Discute-se a interrupção da prescrição do direito a pleitear diferenças de vencimentos a professores do Estado do Amapá por força do desvio de função, na hipótese em que foi ajuizada ação com o mesmo pedido e causa de pedir pelo Sindicato e a ação foi extinta sem julgamento do mérito.

871 Discute: (i) atribuição do encargo de antecipar os honorários periciais ao autor da liquidação de sentença, no caso de perícia determinada de ofício; (ii) possibilidade de atribuição do encargo ao réu, na hipótese em que o autor seja beneficiário da gratuidade da justiça.

872 Questão referente à distribuição dos encargos de sucumbência, à luz do princípio da causalidade, quando julgado procedente o pedido em Embargos de Terceiro que foram ajuizados com o objetivo de anular penhora de imóvel cuja transcrição, no Registro competente, não está atualizada.
873 Discute: (i) possibilidade de cumulação de dividendos e juros sobre capital próprio; (ii) possibilidade de inclusão de juros sobre capital próprio nos cálculos exequendos sem previsão no título executivo judicial.

874 Discute a possível responsabilidade do Banco do Brasil, na condição de gestor do Cadastro de Emitentes de Cheques sem Fundos (CCF), de notificar previamente o devedor acerca da sua inscrição no aludido cadastro.
875 Discussão sobre o termo inicial da prescrição nas demandas por indenização do seguro DPVAT nos casos de invalidez permanente da vítima.
A citação válida em processo extinto sem julgamento do mérito importa na interrupção do prazo prescricional, que volta a correr com o trânsito em julgado da sentença de extinção do processo.

Na fase autônoma de liquidação de sentença (por arbitramento ou por artigos), incumbe ao devedor a antecipação dos honorários periciais.

Nos Embargos de Terceiro cujo
pedido foi acolhido para desconstituir a constrição judicial, os honorários advocatícios serão arbitrados com base no princípio da causalidade, responsabilizando-se o atual proprietário (embargante), se este não atualizou os dados cadastrais. Os encargos de sucumbência serão suportados pela parte embargada, porém, na hipótese em que esta, depois de tomar ciência da transmissão do bem, apresentar ou insistir na impugnação ou recurso para manter a penhora sobre o bem cujo domínio foi transferido para terceiro.

Nas demandas por complementação de ações de empresas de telefonia, admite-se a condenação ao pagamento de dividendos e juros sobre capital próprio independentemente de pedido expresso.

O Banco do Brasil, na condição de mero operador e gestor do Cadastro de Emitentes de Cheques sem Fundos - CCF, não detém legitimidade passiva para responder por danos resultantes da ausência de notificação prévia do correntista acerca de sua inscrição no referido cadastro, obrigação que incumbe ao banco sacado, junto ao qual o correntista mantém relação contratual.

Exceto nos casos de invalidez permanente notória, ou naqueles em que o conhecimento anterior resulte comprovado na fase de instrução, a ciência inequívoca do caráter permanente da invalidez depende de laudo médico.

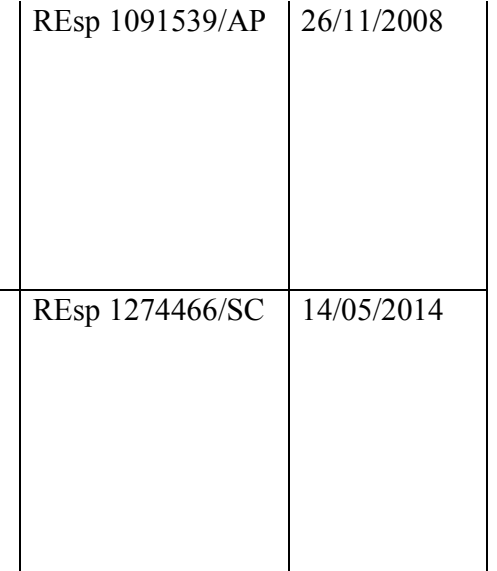


876 Discute a obrigatoriedade, ou não, da indicação do CNPJ para o recebimento da petição inicial de execução fiscal endereçada contra pessoa jurídica.
877 Discussão alusiva ao termo inicial da fluência da prescrição quinquenal para o ajuizamento da ação individual executiva para cumprimento de sentença originária de ação civil pública.

881 Discussão alusiva à incidência de imposto de renda sobre o adicional de $1 / 3$ (um terço) de férias gozadas.

883 Questão referente ao prazo de prescrição das ações que buscam a indenização securitária, bem como daquelas que buscam a complementação de pagamento, relativa ao Seguro de Danos Pessoais Causados por Veículos Automotores de Via Terrestre (DPVAT).

885 Controvérsia alusiva à possibilidade do prosseguimento de ações de cobrança ou execuções ajuizadas em face de devedores solidários ou coobrigados em geral, depois de deferida a recuperação judicial ou mesmo depois de aprovado o plano de recuperação do devedor principal.
Em ações de execução fiscal, descabe indeferir a petição inicial sob o argumento da falta de indicação do CPF e/ou RG da parte executada (pessoa física), visto tratar-se de requisito não previsto no art. $6^{\circ}$ da Lei $\mathrm{n}^{\circ} 6.830 / 80$ (LEF), cujo diploma, por sua especialidade, ostenta primazia sobre a legislação de cunho geral, como ocorre frente à exigência contida no art. 15 da Lei $\mathrm{n}^{\circ}$ 11.419/06.Em ações de execução fiscal, descabe indeferir a petição inicial sob o argumento da falta de indicação do CNPJ da parte executada (pessoa jurídica), visto tratar-se de requisito não previsto no art. $6^{\circ}$ da Lei $\mathrm{n}^{\circ} 6.830 / 80$ (LEF), cujo diploma, por sua especialidade, ostenta primazia sobre a legislação de cunho geral, como ocorre frente à exigência contida no art. 15 da Lei ${ }^{\circ} 11.419 / 06$. O prazo prescricional para a execução individual é contado do trânsito em julgado da sentença coletiva, sendo desnecessária a providência de que trata o art. 94 da Lei n.8.078/90.

Incide imposto de renda sobre o adicional de 1/3 (um terço) de férias gozadas.

A pretensão de cobrança e a pretensão a diferenças de valores do seguro obrigatório (DPVAT) prescrevem em três anos, sendo o termo inicial, no último caso, o pagamento administrativo considerado a menor.

A recuperação judicial do devedor principal não impede o prosseguimento das execuções nem induz suspensão ou extinção de ações ajuizadas contra terceiros devedores solidários ou coobrigados em geral, por garantia cambial, real ou fidejussória, pois não se lhes aplicam a suspensão prevista nos arts. $6^{\circ}$, caput, e 52, inciso III, ou a novação a que se refere o art. 59, caput, por força do que dispõe o art. $49, \S 1^{\circ}$, todos da Lei n. 11.101/2005.

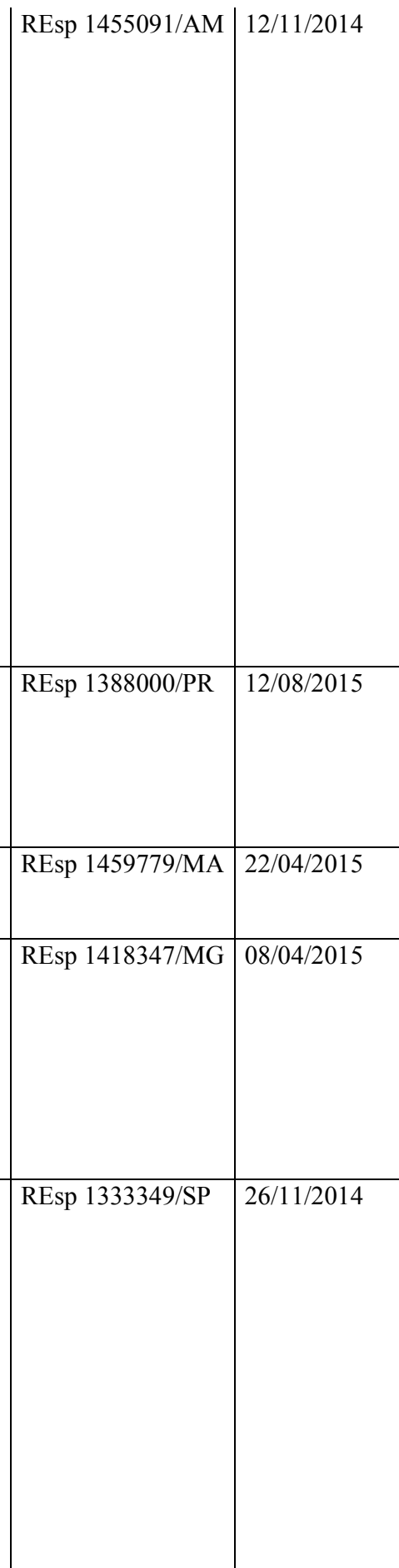


886 Controvérsia sobre quem tem legitimidade - vendedor ou adquirente condominiais na hipótese de alienação da unidade, notadamente quando se tratar de compromisso de compra e venda não levado a registro. - para responder por dívidas
889 Controvérsia alusiva à exequibilidade de sentenças não condenatórias (de regra, declaratórias), notadamente após o acréscimo do art. 475-N, inciso I, ao Código de Processo Civil, pela Lei n. 11.232/2005, seja quando figura como exequente $\mathrm{o}$ autor do processo de conhecimento, seja quando figura o réu.

890 Possibilidade de inclusão de juros remuneratórios na fase de cumprimento individual de sentença, na hipótese de não haver condenação a tal rubrica no título judicial formado em sede de ação civil pública - no caso, sentença proferida na Ação Civil Pública n. 583.00.1994.700585-2, ajuizada pelo IDEC em desfavor de Banco Meridional S/A, a qual tramitou na 30a Vara Cível da Comarca de São Paulo/SP

891 Controvérsia alusiva à possibilidade de, na hipótese de condenação referente aos expurgos inflacionários do Plano Verão (janeiro de 1989), incluírem-se nos cálculos de liquidação de sentença os expurgos relativos aos planos econômicos subsequentes, a título de correção monetária do débito. a) $\mathrm{O}$ que define a responsabilidade pelo pagamento das obrigações condominiais não é o registro do compromisso de venda e compra, mas a relação jurídica material com o imóvel, representada pela imissão na posse pelo promissário comprador e pela ciência inequívoca do Condomínio acerca da transação;b) Havendo compromisso de compra e venda não levado a registro, a responsabilidade pelas despesas de condomínio pode recair tanto sobre o promitente vendedor quanto sobre o promissário comprador, dependendo das circunstâncias de cada caso concreto; c) Se restar comprovado: (i) que o promissário comprador imitirase na posse; e (ii) o Condomínio teve ciência inequívoca da transação, afasta-se a legitimidade passiva do promitente vendedor para responder por despesas condominiais relativas a período em que a posse foi exercida pelo promissário comprador.

A sentença, qualquer que seja sua
natureza, de procedência ou improcedência do pedido, constitui título executivo judicial, desde que estabeleça obrigação de pagar quantia, de fazer, não fazer ou entregar coisa, admitida sua prévia liquidação e execução nos próprios autos.

$\mathrm{Na}$ execução individual de sentença proferida em ação civil pública que reconhece o direito de poupadores aos expurgos inflacionários decorrentes do Plano Verão (janeiro de 1989), descabe a inclusão de juros remuneratórios nos cálculos de liquidação se inexistir condenação expressa, sem prejuízo de, quando cabível, o interessado ajuizar ação individual de conhecimento.

$\mathrm{Na}$ execução de sentença que reconhece o direito de poupadores aos expurgos inflacionários decorrentes do Plano Verão (janeiro de 1989), incidem os expurgos inflacionários posteriores a título de correção monetária plena do débito judicial, que terá como base de cálculo o saldo existente ao tempo do referido plano econômico, e não os valores de eventuais depósitos da época de cada plano subsequente.

892 Controvérsia referente à incidência do reajuste de $28,86 \%$ sobre a Gratificação de Estímulo à Fiscalização e Arrecadação - GEFA no período de 1995 a 1999.

Gratificação de Estímulo à
Incide o reajuste de $28,86 \%$ sobre a

Fiscalização e Arrecadação - GEFA, após a edição da Medida Provisória 831/1995 e até a edição da Medida Provisória 1.915-1/1999, mais precisamente no período de janeiro de 1995 a julho de 1999.

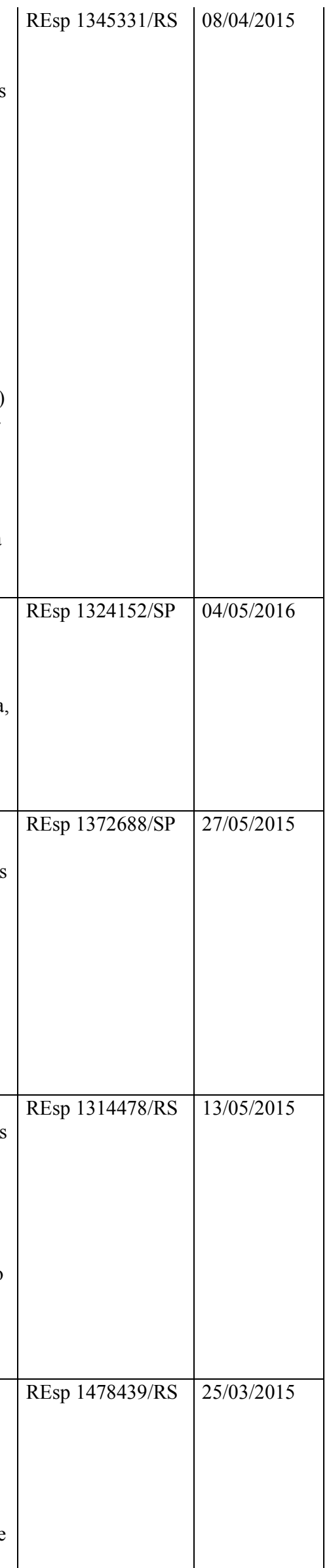


893 Controvérsia referente ao cabimento ou não da multa do artigo $475-\mathrm{J}$ do CPC no âmbito de cumprimento de sentença arbitral.

94 Verificação do índice de atualização (SELIC ou FACDT) aplicável sobre os valores originais do imposto de renda apurado pelo regime de competência até o recebimento da verba acumulada, a fim de se liquidar a repetição de indébito de imposto de renda indevidamente retido sob o regime de caixa.

898 Controvérsia referente à atualização monetária das indenizações previstas no art. $3^{\circ}$ da Lei 6.194/74, com redação dada pela Medida Provisória n. 340/2006, convertida na Lei $11.482 / 07$

901 Discute se o crime do art. 310 do Código de Trânsito Brasileiro seria de perigo abstrato ou exigiria a demonstração de ocorrência de perigo concreto.

902 Definir se, em ação cautelar de sustação de protesto, a prestação de contracautela é dispensável ao deferimento da liminar para suspensão dos efeitos do protesto.

903 Discussão: definição acerca do momento em que verificado o lançamento e a sua notificação quanto ao crédito tributário de IPVA, com o escopo de fixar o termo inicial do prazo prescricional para a cobrança do crédito respectivo.
No âmbito do cumprimento de sentença arbitral condenatória de prestação pecuniária, a multa de $10 \%$ (dez por cento) do artigo 475-J do CPC deverá incidir se o executado não proceder ao pagamento espontâneo no prazo de 15 (quinze) dias contados da juntada do mandado de citação devidamente cumprido aos autos (em caso de título executivo contendo quantia líquida) ou da intimação do devedor, na pessoa de seu advogado, mediante publicação na imprensa oficial (em havendo prévia liquidação da obrigação certificada pelo juízo arbitral).

Até a data da retenção na fonte, a correção do IR apurado e em valores originais deve ser feita sobre a totalidade da verba acumulada e pelo mesmo fator de atualização monetária dos valores recebidos acumuladamente, sendo que, em ação trabalhista, o critério utilizado para tanto é o FACDT- fator de atualização e conversão dos débitos trabalhistas.

\begin{tabular}{|l|l|l|} 
A incidência de atualização monetária & REsp 1483620/SC & 27/05/2015
\end{tabular} nas indenizações por morte ou invalidez do seguro DPVAT, prevista no $\S 7^{\circ}$ do art. $5^{\circ}$ da Lei n. 6194/74, redação dada pela Lei n. 11.482/2007, opera-se desde a data do evento danoso.

É de perigo abstrato o crime previsto no art. 310 do Código de Trânsito Brasileiro. Assim, não é exigível, para o aperfeiçoamento do crime, a ocorrência de lesão ou de perigo de dano concreto na conduta de quem permite, confia ou entrega a direção de veículo automotor a pessoa não habilitada, com habilitação cassada ou com o direito de dirigir suspenso, ou ainda a quem, por seu estado de saúde, física ou mental, ou por embriaguez, não esteja em condições de conduzi-lo com segurança.

\section{A legislação de regência estabelece} que o documento hábil a protesto extrajudicial é aquele que caracteriza prova escrita de obrigação pecuniária líquida, certa e exigível. Portanto, a sustação de protesto de título, por representar restrição a direito do credor, exige prévio oferecimento de contracautela, a ser fixada conforme o prudente arbítrio do magistrado.

A notificação do contribuinte para o recolhimento do IPVA perfectibiliza a constituição definitiva do crédito tributário, iniciando-se o prazo prescricional para a execução fiscal no dia seguinte à data estipulada para o vencimento da exação.

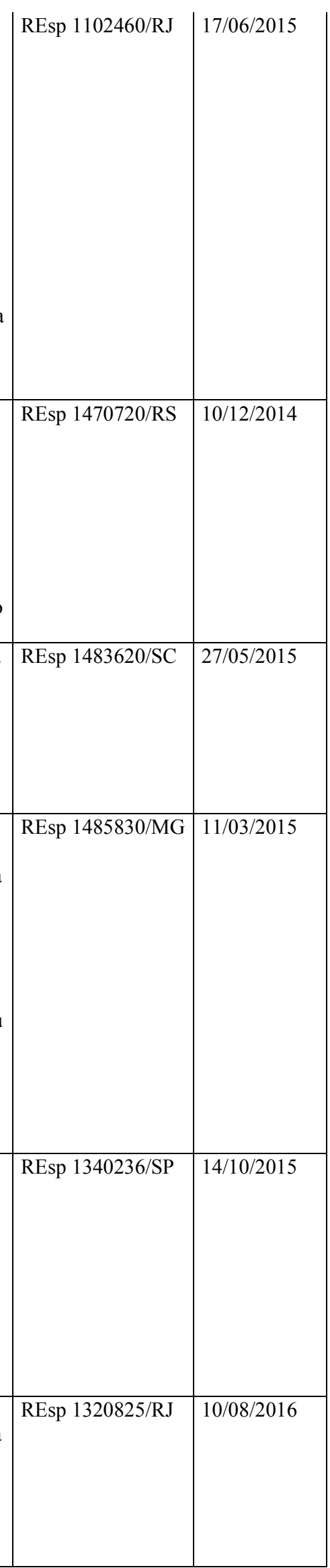


913 Discute: I - se a nomeação à penhora de cotas de fundo de investimento, nos moldes oferecidos pelo banco executado, subsume-se à ordem de preferência legal disposta no inciso I artigo 655 do Código de Processo Civil (dinheiro em aplicações financeiras); e II - se a recusa da nomeação à penhora de cotas de fundo de investimento torna a situação do devedor excessivamente gravosa, viola o recolhimento dos depósitos compulsórios e voluntários ao Banco Central do Brasil e fere a impenhorabilidade das reservas bancárias obrigatórias".

915 Discussão sobre "a existência de interesse de agir nas ações cautelares de exibição de documentos e/ou dados relativos a histórico de cadastro e/ou consultas concernentes ao sistema scoring de pontuação mantidos por entidades de proteção ao crédito".
I - A cota de fundo de investimento não se subsume à ordem de preferência legal disposta no inciso I do art. 655 do CPC/73 (ou no inciso I do art. 835 do NCPC).II - A recusa da nomeação à penhora de cotas de fundo de investimento, reputada legítima a partir das particularidades de cada caso concreto, não encerra, em si, excessiva onerosidade ao devedor, violação do recolhimento dos depósitos compulsórios e voluntários do Banco Central do Brasil ou afronta à impenhorabilidade das reservas obrigatórias.

Em relação ao sistema "credit scoring", o interesse de agir para a propositura da ação cautelar de exibição de documentos exige, no mínimo, a prova de: i) requerimento para obtenção dos dados ou, ao menos, a tentativa de fazê-lo à instituição responsável pelo sistema de pontuação, com a fixação de prazo razoável para atendimento; e ii) que a recusa do crédito almejado ocorreu em razão da pontuação que lhe foi atribuída pelo sistema "scoring".
916 Discute se o crime de roubo, na situação em que o seu autor não teve a posse mansa e pacífica da coisa subtraída, deve ser considerado consumado ou apenas tentado.

917 Definir se é possível remir parte do tempo de execução da pena pelo desempenho de trabalho externo prestado por apenado em regime semiaberto.

918 Discute se a aquiescência da vítima menor de catorze anos possui relevância jurídico-penal a afastar a tipicidade do crime previsto no art. 217-A do Código Penal, acrescentado pela Lei n. 12.015, de 7 de agosto de 2009 - estupro de vulnerável.

\section{Consuma-se o crime de roubo com a} inversão da posse do bem, mediante emprego de violência ou grave ameaça, ainda que por breve tempo e em seguida a perseguição imediata ao agente e recuperação da coisa roubada, sendo prescindível a posse mansa e pacífica ou desvigiada. É possível a remição de parte do tempo de execução da pena quando o condenado, em regime fechado ou semiaberto, desempenha atividade laborativa extramuros.

Para a caracterização do crime de estupro de vulnerável previsto no art. 217-A, caput, do Código Penal, basta que o agente tenha conjunção carnal ou pratique qualquer ato libidinoso com pessoa menor de 14 anos. $\mathrm{O}$ consentimento da vítima, sua eventual experiência sexual anterior ou a existência de relacionamento amoroso entre o agente e a vítima não afastam a ocorrência do crime.

920 Discussão: se a suspensão condicional do processo prevista no art. $89, \S 4^{\circ}$, da Lei n. 9.099/1995 pode ser revogada após o término do benefício, se descumpridas, pelo réu, durante esse prazo, as condições impostas pelo magistrado.

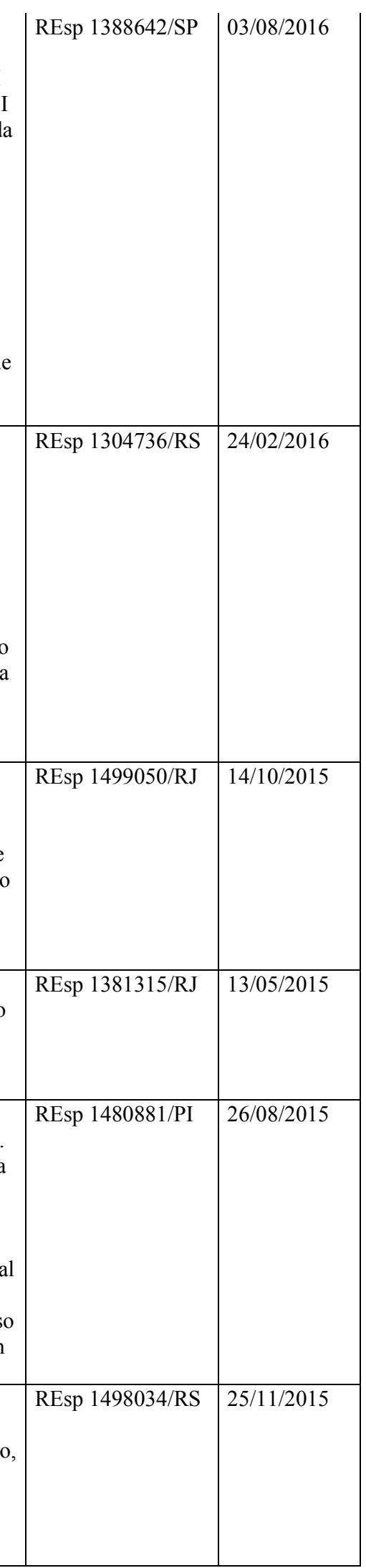


921 Discute-se a validade do protesto do título por tabelionado localizado em comarca diversa da de domicílio do devedor, para fins de comprovação da mora nos contratos garantidos por alienação fiduciária.
924 Estabelecer se a existência de sistema de vigilância, monitoramento ou segurança torna impossível a prática de furto cometido no interior de estabelecimento comercial.

926 Estabelecer se a materialidade do crime previsto no art. $184, \S 2^{\circ}$, do Código Penal pode ser comprovada mediante laudo pericial feito por amostragem do produto apreendido, se a falsidade pode ser atestada por meio das características externas desse material e se é necessária a Identificação dos titulares dos direitos autorais violados.

930 Estabelecer se o acordo processual, na forma do art. $89, \S 2^{\circ}$ da Lei $n$. 9.099/95, pode incluir o cumprimento de condições, aceitas pelo réu, consistentes em prestação pecuniária à vítima, fornecimento de cestas básicas, prestação de serviços à comunidade e outras injunções que, do ponto de vista prático, sejam equivalentes a penas restritivas de direitos.

933 Discute-se a incidência do princípio da consunção quando a falsificação de papéis públicos, crime de maior gravidade, assim considerado pela pena abstratamente cominada, é meio ou fase necessária ao descaminho, crime de menor gravidade.

934 Discussão: se o crime de furto, na situação em que o seu autor não teve a posse mansa e pacífica da coisa subtraída, deve ser considerado consumado ou apenas tentado.
1. O tabelião, antes de intimar o devedor por edital, deve esgotar os meios de localização, notadamente por meio do envio de intimação por via postal, no endereço fornecido por aquele que procedeu ao apontamento do protesto;2. É possível, à escolha do credor, o protesto de cédula de crédito bancário garantida por alienação fiduciária, no tabelionato em que se situa a praça de pagamento indicada no título ou no domicílio do devedor.

A existência de sistema de segurança ou de vigilância eletrônica não torna impossível, por si só, o crime de furto cometido no interior de estabelecimento comercial.

É suficiente, para a comprovação da materialidade do delito previsto no art. $184, \S 2^{\circ}$, do Código Penal, a perícia realizada, por amostragem, sobre os aspectos externos do material apreendido, sendo desnecessária a identificação dos titulares dos direitos autorais violados ou de quem os represente.

Não há óbice a que se estabeleçam, no prudente uso da faculdade judicial disposta no art. $89, \S 2^{\circ}$, da Lei $n$. $9.099 / 1995$, obrigações equivalentes, do ponto de vista prático, a sanções penais (tais como a prestação de serviços comunitários ou a prestação pecuniária), mas que, para os fins do sursis processual, se apresentam tão somente como condições para sua incidência.

Quando o falso se exaure no
descaminho, sem mais potencialidade lesiva, é por este absorvido, como crime-fim, condição que não se altera por ser menor a pena a este cominada.

Consuma-se o crime de furto com a posse de fato da res furtiva, ainda que por breve espaço de tempo e seguida de perseguição ao agente, sendo prescindível a posse mansa e pacífica ou desvigiada.

\begin{tabular}{|c|c|}
\hline REsp 1398356/MG & |24/02/2016 \\
\hline REsp 1385621/MG & $27 / 05 / 2015$ \\
\hline REsp 1456239/MG & $12 / 08 / 2015$ \\
\hline REsp 1498034/RS & 25/11/2015 \\
\hline REsp 1378053/PR & $10 / 08 / 2016$ \\
\hline REsp 1524450/RJ & $14 / 10 / 2015$ \\
\hline
\end{tabular}




\begin{tabular}{|c|c|c|c|c|}
\hline 938 & $\begin{array}{l}\text { Discussão quanto à: (i) prescrição da } \\
\text { pretensão de restituição das parcelas } \\
\text { pagas a título de comissão de } \\
\text { corretagem e de assessoria imobiliária, } \\
\text { sob o fundamento da abusividade da } \\
\text { transferência desses encargos ao } \\
\text { consumidor; e quanto à (ii) validade } \\
\text { da cláusula contratual que transfere ao } \\
\text { consumidor a obrigação de pagar } \\
\text { comissão de corretagem e taxa de } \\
\text { assessoria técnico-imobiliária (SATI). }\end{array}$ & $\begin{array}{l}\text { (i) Incidência da prescrição trienal } \\
\text { sobre a pretensão de restituição dos } \\
\text { valores pagos a título de comissão de } \\
\text { corretagem ou de serviço de } \\
\text { assistência técnico-imobiliária } \\
\text { (SATI), ou atividade congênere } \\
\text { (artigo } 206, \S 3^{\circ}, \text { IV, CC). (vide REsp } \\
\text { n. } 1.551 .956 / \text { SP)(ii) Validade da } \\
\text { cláusula contratual que transfere ao } \\
\text { promitente-comprador a obrigação de } \\
\text { pagar a comissão de corretagem nos } \\
\text { contratos de promessa de compra e } \\
\text { venda de unidade autônoma em } \\
\text { regime de incorporação imobiliária, } \\
\text { desde que previamente informado o } \\
\text { preço total da aquisição da unidade } \\
\text { autônoma, com o destaque do valor da } \\
\text { comissão de corretagem; (vide REsp } \\
\text { n. } 1.599 .511 / \text { SP)(ii, parte final) } \\
\text { Abusividade da cobrança pelo } \\
\text { promitente-vendedor do serviço de } \\
\text { assessoria técnico-imobiliária (SATI), } \\
\text { ou atividade congênere, vinculado à } \\
\text { celebração de promessa de compra e } \\
\text { venda de imóvel. (vide REsp n. } \\
1.599 .511 / \text { SP) }\end{array}$ & REsp 1599511/SP & $24 / 08 / 2016$ \\
\hline 942 & $\begin{array}{l}\text { Definir:I) qual deve ser o termo inicial } \\
\text { para incidência de atualização } \\
\text { monetária de crédito estampado em } \\
\text { cheque.eII) o dies a quo para } \\
\text { contagem de juros de mora, no tocante } \\
\text { a crédito oriundo de cheque. }\end{array}$ & $\begin{array}{l}\text { Em qualquer ação utilizada pelo } \\
\text { portador para cobrança de cheque, a } \\
\text { correção monetária incide a partir da } \\
\text { data de emissão estampada na cártula, } \\
\text { e os juros de mora a contar da } \\
\text { primeira apresentação à instituição } \\
\text { financeira sacada ou câmara de } \\
\text { compensação. }\end{array}$ & REsp 1556834/SP & $22 / 06 / 2016$ \\
\hline 944 & $\begin{array}{l}\text { Definir se o participante de plano de } \\
\text { benefícios de previdência privada } \\
\text { patrocinado por entidade da } \\
\text { administração pública pode se tornar } \\
\text { elegível a um benefício de prestação } \\
\text { programada e continuada, sem que } \\
\text { tenha havido a cessação do vínculo } \\
\text { com o patrocinador. }\end{array}$ & $\begin{array}{l}\text { Nos planos de benefícios de } \\
\text { previdência privada patrocinados } \\
\text { pelos entes federados - inclusive suas } \\
\text { autarquias, fundações, sociedades de } \\
\text { economia mista e empresas } \\
\text { controladas direta ou indiretamente -, } \\
\text { para se tornar elegível a um benefício } \\
\text { de prestação que seja programada e } \\
\text { continuada, é necessário que o } \\
\text { participante previamente cesse o } \\
\text { vínculo laboral com o patrocinador, } \\
\text { sobretudo a partir da vigência da Lei } \\
\text { Complementar } n^{\circ} 108 / 2001 \text {, } \\
\text { independentemente das disposições } \\
\text { estatutárias e regulamentares. }\end{array}$ & REsp 1433544/SE & $09 / 11 / 2016$ \\
\hline 945 & $\begin{array}{l}\text { Definir se: I) a pactuação extracartular } \\
\text { da pós-datação do cheque tem eficácia, } \\
\text { no tocante ao direito cambiário; e II) é } \\
\text { possível o apontamento a protesto de } \\
\text { cheque, ainda que após o prazo de } \\
\text { apresentação, mas dentro do período } \\
\text { para ajuizamento da ação cambial de } \\
\text { execução. }\end{array}$ & $\begin{array}{l}\text { a) a pactuação da pós-datação de } \\
\text { cheque, para que seja hábil a ampliar } \\
\text { o prazo de apresentação à instituição } \\
\text { financeira sacada, deve espelhar a } \\
\text { data de emissão estampada no campo } \\
\text { específico da cártula;b) sempre será } \\
\text { possível, no prazo para a execução } \\
\text { cambial, o protesto cambiário de } \\
\text { cheque, com a indicação do emitente } \\
\text { como devedor. }\end{array}$ & REsp 1423464/SC & $27 / 04 / 2016$ \\
\hline
\end{tabular}

